\title{
Instrumenty prawne Wspólnej Polityki Rolnej wpływające na konkurencyjność polskiego rolnictwa
}





\section{Instrumenty prawne Wspólnej Polityki Rolnej wpływające
na konkurencyjność
polskiego rolnictwa wpływające
na konkurencyjność
polskiego rolnictwa wpływające
na konkurencyjność
polskiego rolnictwa}

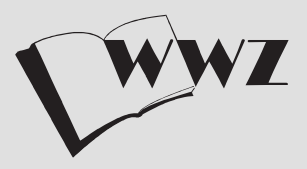

Wydawnictwo Naukowe Wydziału Zarządzania Uniwersytetu Warszawskiego

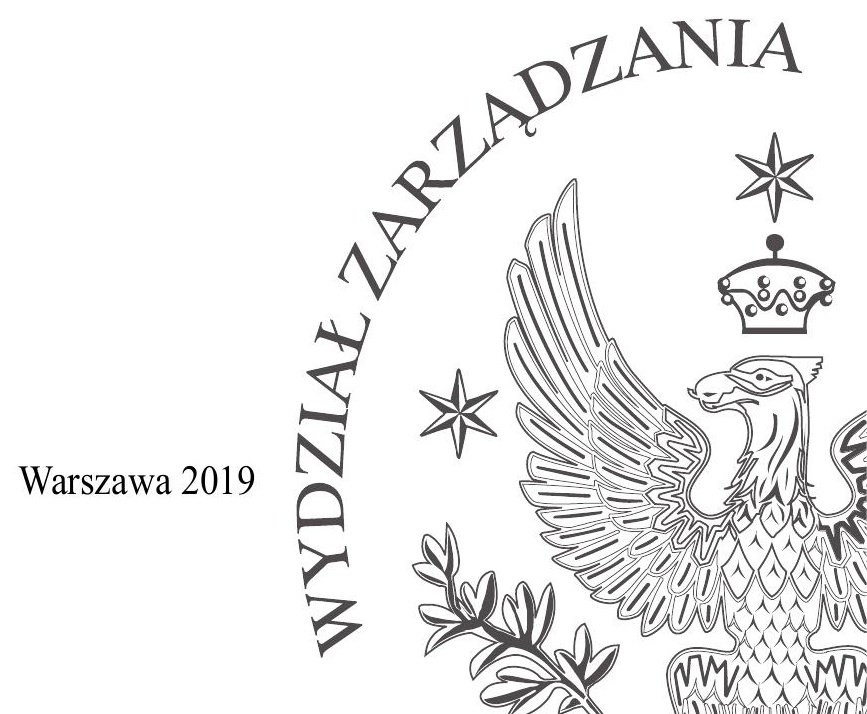


Recenzenci: dr hab. prof. UMCS Beata Jeżyńska, dr hab. prof. UŁ Monika A. Król

Redakcja: Teresa Pawlak-Lis

Projekt okładki: Agnieszka Miłaszewicz

(C) Copyright by Wydawnictwo Naukowe Wydziału Zarządzania Uniwersytetu Warszawskiego, Warszawa 2019

Wszelkie prawa zastrzeżone. Kopiowanie, przedrukowywanie i rozpowszechnianie całości lub fragmentów bez uzyskania pozwolenia zabronione.

ISBN 978-83-66282-13-1

eISBN 978-83-66282-14-8

DOI $\quad 10.7172 / 978-83-66282-13-1.2019 .6$

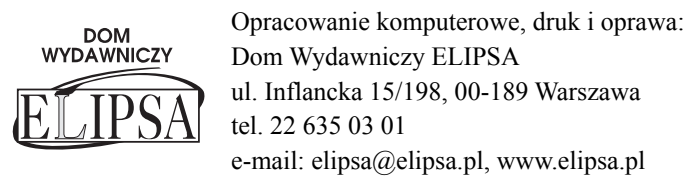




\section{Spis treści}

Wykaz skrótów

Wstęp

Rozdzial 1. Konkurencyjność w nauce i prawie.................................................. 19

1.1. Konkurencyjność w nauce i teorii ......................................................... 20

1.2. Zasoby a konkurencyjność rolnictwa w Polsce ………............................... 29

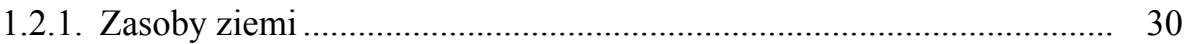

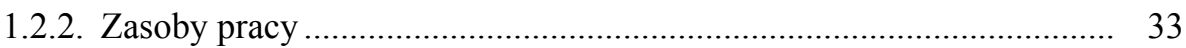

1.2.3. Inne wybrane zasoby, mające wpływ na konkurencyjność rolnictwa... 37

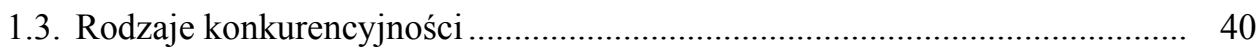

1.3.1. Konkurencyjność sektorowa .......................................................... 40

1.3.2. Konkurencyjność regionalna .......................................................... 42

1.3.3. Konkurencyjność mikroekonomiczna ............................................. 43

1.4. Konkurencyjność jako kategoria prawna w regulacjach rolnych ................... 45

1.5. Podsumowanie ............................................................................................. 48

Rozdzial 2. Ewolucja Wspólnej Polityki Rolnej a konkurencyjność rolnictwa .... 50

2.1. Powstanie Wspólnej Polityki Rolnej i założeń konkurencyjności rolnictwa... 51

2.2. Mechanizmy protekcjonistyczne Wspólnej Polityki Rolnej ............................ 53

2.3. Instrumenty prawno-organizacyjne ograniczenia produkcji rolnej ................ 55

2.4. Reforma MacSharry'ego, czyli odejście od silnego protekcjonizmu ............. 57

2.5. Polityka rozwoju obszarów wiejskich i polityka prośrodowiskowa................ 58

2.6. Zazielenienie jako kierunek rozwoju Wspólnej Polityki Rolnej ..................... 60

2.7. Przyszłość Wspólnej Polityki Rolnej w aspekcie konkurencyjności rolnic-

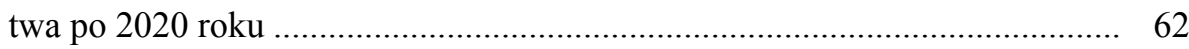

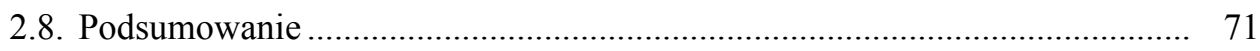

Rozdzial 3. Podstawy prawne rozdysponowywania funduszy europejskich wpływających na konkurencyjność rolnictwa ………....................................... 75

3.1. Regulacje europejskie dotyczące konkurencyjności rolnictwa ...................... 76

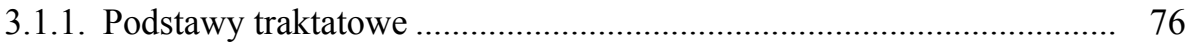

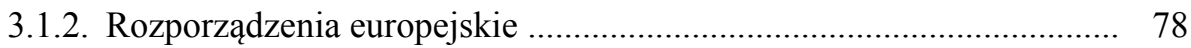

3.1.2.1. Rozporządzenie 1303/2013 ………………………............. 79 
3.1.2.2. Rozporządzenie $1305 / 2013$................................................ 80

3.1.2.3. Rozporządzenie $1306 / 2013$................................................. 82

3.1.2.4. Rozporządzenie $1307 / 2013$............................................... 82

3.1.2.5. Rozporządzenie 1308/2013 ……………………................ 83

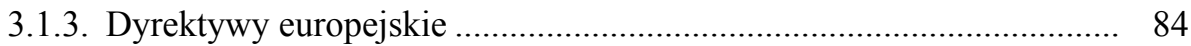

3.1.4. Akty o charakterze nienazwanym typu soft law ................................. 85

3.2. Regulacje krajowe dotyczące konkurencyjności rolnictwa ........................... 86

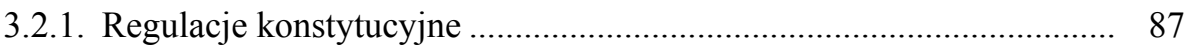

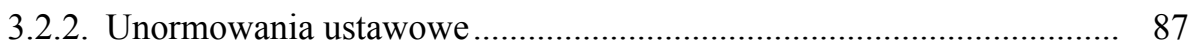

3.2.2.1. Ustawa o wspieraniu rozwoju obszarów wiejskich z udziałem środków Europejskiego Funduszu Rolnego na rzecz Rozwoju Obszarów Wiejskich w ramach Programu Rozwoju Obszarów Wiejskich na lata 2014-2020

3.2.2.2. Ustawa o płatnościach w ramach systemów wsparcia bezpo-

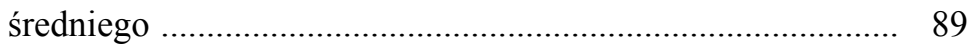

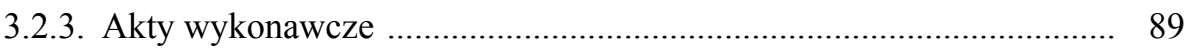

3.2.4. Akty o charakterze quasi prawnym …………….............................. 90

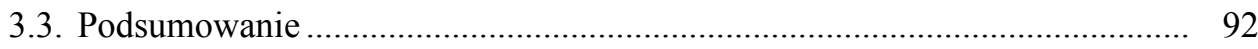

Rozdzial 4. Instrumenty prawne Wspólnej Polityki Rolnej wpływające na kon-

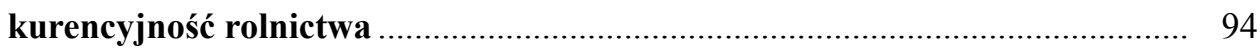

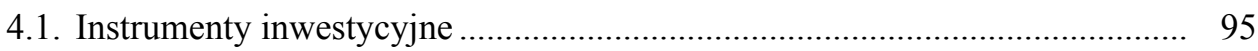

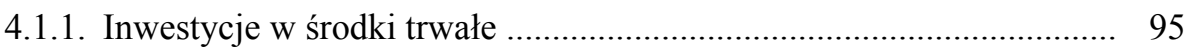

4.1.2. Wsparcie na przystępowanie do systemów jakości .............................. 99

4.1.3. Wsparcie inwestycji związanych z tworzeniem, ulepszaniem lub rozbudową wszystkich rodzajów małej infrastruktury, w tym inwestycje w energię odnawialną i w oszczędzanie energii ..................................... 100

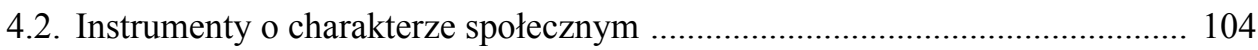

4.2.1. Premia dla młodych rolników ............................................................ 104

4.2.2. Pomoc dla rolników zaprzestających prowadzenia działalności rol-

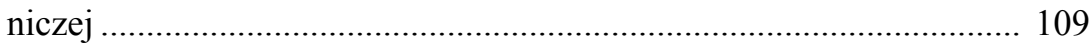

4.2.3. Tworzenie grup producentów rolnych ............................................. 112

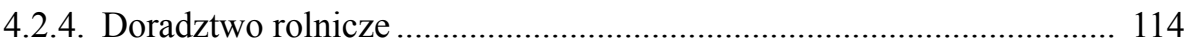

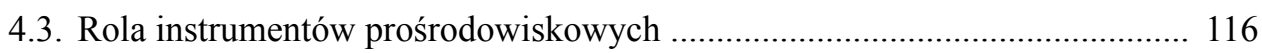

4.3.1. Płatności bezpośrednie a polityka zazieleniania ................................. 116

4.3.2. Działanie rolno-środowiskowo-klimatyczne ...................................... 120

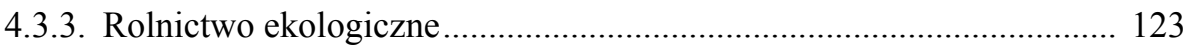

4.4. Płatności bezpośrednie jako instrument wpływający na konkurencyjność

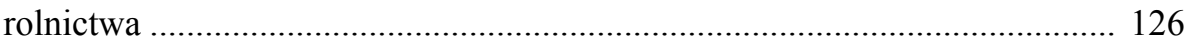

4.5. Instrumenty funkcjonujące na jednolitym rynku rolnym ............................... 128 
4.5.1. Instrumenty funkcjonujące na jednolitym rynku wewnątrz Unii Euro-

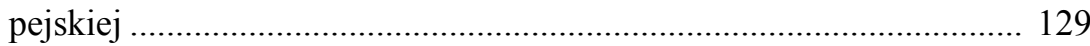

4.5.1.1. Interwencja publiczna na rynku rolnym ............................... 129

4.5.1.2. Dopłaty do prywatnego przechowania .................................... 131

4.5.1.3. Programy pomocy ................................................................... 131

4.5.1.4. Instrumenty wprowadzenia do obrotu produktów rolnych ..... 132

4.5.1.5. Organizacje i zrzeszenia producentów oraz organizacje międzybranżowe

4.5.2. Instrumenty funkcjonujące na jednolitym rynku w handlu z państwa-

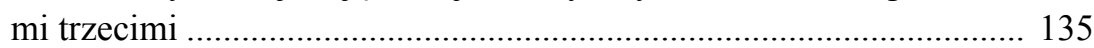

4.5.2.1. Pozwolenia na przywóz i wywóz ........................................ 136

4.5.2.2. Administrowanie kontyngentem taryfowym ......................... 137

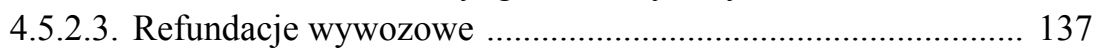

4.6. Mechanizmy prawne wynikające $\mathrm{z}$ soft law .................................................. 138

4.6.1. Obrót nieruchomościami rolnymi w świetle soft law ........................... 139

4.6.2. Instrumenty wynikające ze strategii i programów europejskich i kra-

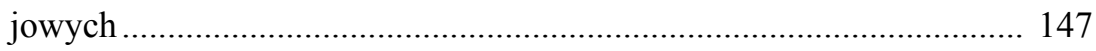

4.7. Instrumenty prawne wpływające na konkurencyjność rolnictwa w wybra-

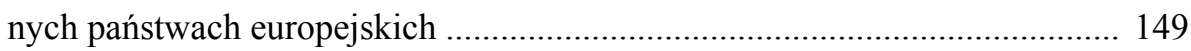

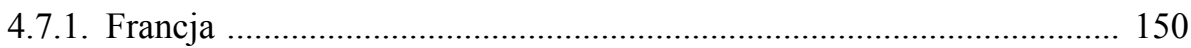

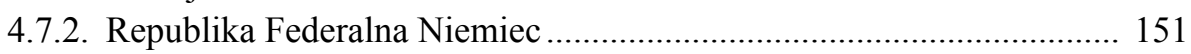

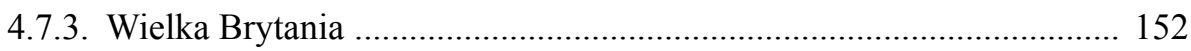

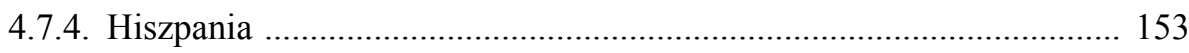

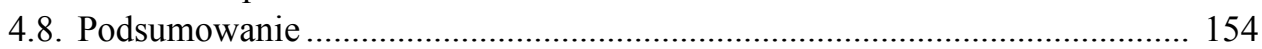

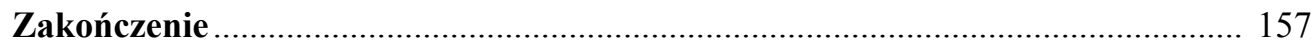

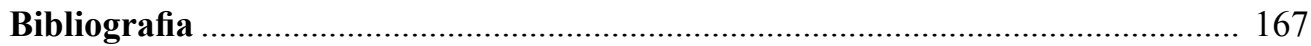

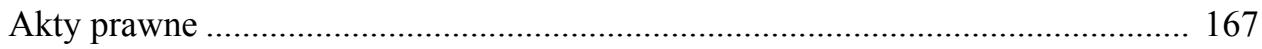

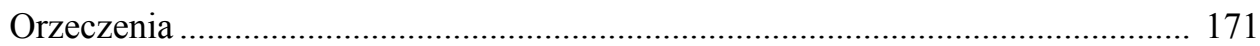

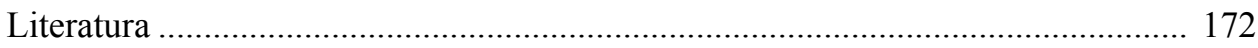

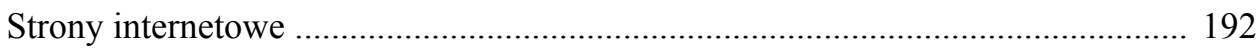





\section{Wykaz skrótów}

AP

ARiMR

ARR

Dz. U.

Dz. Urz. UE

EFR

EFRG

EFRR

EFRROW

EFS

ESU

ETS

EWG

FADN

FAPA

FS

GMO

GUS

GVA

IERiGŻ

k.p.a.

KE

KOWR

KPS

KRUS
Agencja płatnicza

Agencja Restrukturyzacji i Modernizacji Rolnictwa

Agencja Rynku Rolnego

Dziennik Ustaw

Dziennik Urzędowy Unii Europejskiej

Europejski Fundusz Rybacki

Europejski Fundusz Rolniczy Gwarancji

Europejski Fundusz Rozwoju Regionalnego

Europejski Fundusz Rolny na rzecz Rozwoju Obszarów Wiejskich

Europejski Fundusz Społeczny

Europejska Jednostka Wielkości, 1 ESU = 1200 EUR

Europejski Trybunał Sprawiedliwości

Europejska Wspólnota Gospodarcza

Europejski system zbierania danych rachunkowych z gospodarstw rolnych (ang. Farm Accountancy Data Network)

Fundacja Programów Pomocy dla Rolnictwa FAPA

Fundusz Spójności

Organizmy Modyfikowane Genetycznie

Główny Urząd Statystyczny

Wartość dodana brutto (ang. Gross Value Added)

Instytut Ekonomiki Rolnictwa i Gospodarki Żywnościowej

Kodeks postępowania administracyjnego

Komisja Europejska

Krajowy Ośrodek Wsparcia Rolnictwa

Krajowy Plan Strategicznego Rozwoju Obszarów Wiejskich

Kasa Rolniczego Ubezpieczenia Społecznego 
KSOW Krajowa Sieć Obszarów Wiejskich

KSRR Krajowa Strategia Rozwoju Regionalnego

LGD Lokalna Grupa Działania

LSR

Lokalna Strategia Rozwoju

MRiRW

Ministerstwo Rolnictwa i Rozwoju Wsi

MŚP

Małe i średnie przedsiębiorstwa

NBP

Narodowy Bank Polski

NSA

Naczelny Sąd Administracyjny

ONW

Obszary o niekorzystnych warunkach gospodarowania

PE

Parlament Europejski

PKB

Produkt Krajowy Brutto

PNB

Produkt Narodowy Brutto

PRL

Polska Rzeczpospolita Ludowa

PROW 2007-2013 Program Rozwoju Obszarów Wiejskich na lata 2007-2013

PROW 2014-2020 Program Rozwoju Obszarów Wiejskich na lata 2014-2020

RP Rzeczpospolita Polska

SAPS system jednolitej płatności obszarowej (ang. Single Area Payment Scheme)

SN Sąd Najwyższy

SPS system płatności jednolitej (ang. Single Payment Scheme)

SWOT Analiza SWOT (ang. Strengths - mocne strony, Weaknesses stabe strony, Opportunities - szanse, Threats - zagrożenia)

TFUE Traktat o funkcjonowaniu Unii Europejskiej

TK Trybunał Konstytucyjny

TS

Trybunał Sprawiedliwości

UE Unia Europejska

UR Użytek rolny

WE Wspólnoty Europejskie

WPR Wspólna Polityka Rolna

WRF wieloletnie ramy finansowe

Zb. Orz. Zbiór Orzeczeń 


\section{Wstęp}

Jednym z głównych celów polityki rolnej na świecie jest podnoszenie konkurencyjności rolnictwa zarówno wewnątrz państw, jak i na poziomie międzynarodowym. Wykorzystuje się do tego celu instrumenty prawne, których zadaniem jest pomoc dla rolników. Instrumenty te mają różną postać, od subwencjonowania rolnictwa $\mathrm{i}$ ingerencji państwa w wolny rynek, po dotacje celowe, przeznaczane na konkretne przedsięwzięcia inwestycyjne. Ta różnorodność możliwych rozwiązań prawnych, mających na celu podniesienie poziomu konkurencyjności, jest widoczna zarówno w państwach rozwiniętych, takich jak Stany Zjednoczone, czy państwa Unii Europejskiej, jak i w państwach rozwijających się. Dążenie do maksymalizacji zysku, przy uwzględnieniu kryterium racjonalności, powinno jednakże wiązać się z ochroną środowiska naturalnego, troską o społeczne aspekty działalności rolniczej. Intensywne rolnictwo, sprzyjające podnoszeniu konkurencyjności, poprzez redukcję kosztów produkcji i zwiększanie dochodowości, może okazać się niewystarczające dla spełniania nowych wyzwań i nowych reguł konkurencji.

Wiodącym przykładem ewolucji polityki konkurencyjności rolnictwa, a co za tym idzie ewolucji instrumentów prawnych, które tę konkurencyjność powinny rozwijać, są regulacje Wspólnej Polityki Rolnej. Przystąpienie Polski do Unii Europejskiej w 2004 r. stworzyło możliwość korzystania z funduszy europejskich przez wszystkich polskich obywateli. Już na wstępie należy zauważyć, że blisko 50\% środków budżetu UE przeznaczono na rolnictwo (obserwuje się tutaj tendencję malejącą).

W niniejszej pracy dokonano analizy, jak wydatkowane środki oddziałują na rolnictwo Polski. Badaniu poddano instrumenty prawne Wspólnej Polityki Rolnej, mające wpływ na konkurencyjność polskiego rolnictwa. Próbowano znaleźć odpowiedź na pytanie, czy wybrane instrumenty prawne poprawiają konkurencyjność rolnictwa, czy nie są w tym zakresie dysfunkcyjne.

Poddane analizie prawnej przepisy i ekonomiczne dane $\mathrm{z}$ dotychczasowego wykorzystania funduszy w latach 2004-2017, a także 2014-2020 pozwalają ocenić działanie odpowiednich procedur prawnych oraz efektywność wykorzystywania pozyskiwanej pomocy przez beneficjentów. W tym zakresie badaniu poddano skuteczność poszczególnych instrumentów poprzez analizę problemów prawnych, jakie występują w dostępie do pomocy publicznej. Przez odniesienie się do danych ekonomicznych, zobrazowano tylko te problemy prawne, które utrudniają osiągnięcie założonych celów WPR. Przykładem instrumentu prawnego, który nie spełnia roli poprawy konkurencyjności w tym zakresie, są renty strukturalne. Środki przeznaczane na takie 
działania mają bardziej charakter socjalny, niż rynkowy - inwestycyjny. Powstaje pytanie, jakie instrumenty prawne należy dobrać, aby osiągnąć zakładane cele ekonomiczne oraz realizację celów WPR. Dokonanie oceny na tym etapie budżetowania (w połowie programów z lat 2014-2020) pozwala wskazać na najbardziej korzystne działania z punktu widzenia ekonomicznego w zakresie poprawy efektywności całej gospodarki Polski, a w szczególności polskiego rolnictwa. Pozwala również dokonać oceny ex post $\mathrm{w}$ zakresie możliwych zmian zarówno w procedurach administracyjnych uzyskiwania środków, jak i w konstrukcji prawnej instrumentów prawnych przeznaczonych na realizację celów poprawy konkurencyjności.

Powyższe oceny przybierają na znaczeniu, mając na uwadze globalną sytuację polskiego rolnictwa. Dokonana ocena to nie tylko fundusze pochodzące ze środków Unii Europejskiej, lecz także pomoc krajowa państwa, czy w końcu oddziaływanie sytuacji makroekonomicznej na cały sektor rolny Polski. Na przykładzie realizacji celów WPR doskonale widać także, jak poszczególne rozwiązania prawne są kształtowane pod konkretne założenia ekonomiczne. W tym zakresie współczesne prawo rolne na poziomie europejskim jest mieszanką prawa i ekonomii, które wzajemnie na siebie oddziałują. Jednocześnie niektóre rozwiązania prawne mogą przynosić nieekonomiczne rozwiązania. W tym zakresie ocena poszczególnych instrumentów prawnych odnosi się także do sfery skutków społecznych, rolnośrodowiskowych, klimatycznych.

Te wstępne obserwacje skłoniły do podjęcia badań nad instrumentami prawnymi Wspólnej Polityki Rolnej, mającymi wpływ na konkurencyjność polskiego rolnictwa. Instrumenty ${ }^{1}$ te dotyczą zarówno oddziaływania na rynek wewnątrz Unii Europejskiej, jak również handlu z państwami trzecimi. Wskazówki de lege ferenda mogą być wykorzystane w nowej perspektywie budżetowej po 2020 r., w szczególności obecnie, gdy toczy się europejska debata nie tylko o kształcie polityki rolnej, lecz także o kształcie rolnictwa europejskiego. Obserwacja poszczególnych instrumentów prawnych, mających poprawić konkurencyjność, może okazać się przydatna do odpowiedzi na pytanie: czy dotychczasowy system realizacji celów WPR się sprawdza? Trzeba jednoznacznie wskazać, że rolnictwo nadal w kolejnej perspektywie finansowej będzie miało największe znaczenie w zakresie finansowych zobowiązań wspólnotowych. Wszelkie prace badawcze, które mają usprawnić podział tych środków, mają na celu poprawę skuteczności polskiego rolnictwa w konkurowaniu z pozostałymi krajami Unii Europejskiej, a także Unii Europejskiej z państwami trzecimi, są potrzebne.

${ }^{1}$ Instrumenty te będą rozumiane jako instytucje prawne w ujęciu instytucji Justyniana - por. Instytucje Justyniana, przeł. C. Kunderewicz, Warszawa 1986. Określenie instrumenty prawne jest powszechnie stosowane przez doktrynę, w tym doktrynę prawa rolnego - por. A. Stelmachowski, Modele prawnych instrumentów polityki rolnej, [w:] Prawo rolne, A. Stelmachowski (red.), Warszawa 2005. Zamiennie będzie używane również sformułowanie - „mechanizmy prawne”. Jest ono stosowane także w polskiej nauce prawa rolnego - R. Budzinowski, A. Suchoń, Relacja gospodarstwa rolnego i przedsiębiorstwa rolnego w świetle publicznych mechanizmów ich wspierania, [w:] Prawne mechanizmy wspierania i ochrony rolnictwa rodzinnego w Polsce i innych państwach Unii Europejskiej, P. Litwiniuk (red.), Warszawa 2015. 
Zagadnienia badawcze podjęte w pracy dotyczą następujących hipotez:

1. Fundusze europejskie powodują wzrost konkurencyjności polskiego rolnictwa poprzez zastosowanie odpowiednich instrumentów prawnych do realizacji celu podniesienia konkurencyjności polskiego rolnictwa. Tam, gdzie przepis prawa zakłada działania o charakterze inwestycyjnym rolnik zazwyczaj jest w stanie wykazać na koniec rozliczenia pomocy, że jego gospodarstwo zwiększyło dochodowość. Inaczej sytuacja przedstawia się z mechanizmami prawnymi, których głównym celem są działania społeczne, środowiskowe, klimatyczne, czy aktywizujące. W tym zakresie brak jest jasnych przesłanek do oceny na ile przygotowane instrumenty prawne oddziałują na konkurencyjność rolnictwa. Ogólne analizy ekonomiczne wskazują na wzrost konkurencyjności rolnictwa. Natomiast szczegółowe efekty poszczególnych instrumentów prawnych przedstawiają zróżnicowany obraz. Są mechanizmy, takie jak np. działanie zwiększanie wartości dodanej podstawowej produkcji rolnej i leśnej, gdzie łatwo można wskazać osiągnięty efekt ekonomiczny oraz ewentualne miejsca, gdzie w procesie realizacji inwestycji zawiodły mechanizmy prawne. Istnieją jednakże instrumenty prawne takie jak działania rolno-środowiskowo-klimatyczne, gdzie ocena ich efektywności z punktu widzenia dochodu rolnika jest niezwykle trudna. Trzeba również zwrócić uwagę, że wszelkie próby wyciągania wniosków z podejmowanej pomocy finansowej muszą uwzględniać czynnik czasowy. Obecny okres działania niektórych instrumentów prawnych w zakresie WPR jest niezwykle krótki, aby można ocenić jego przydatność dla sektora rolnego.

2. Konkurencyjność rolnictwa, jako cel Wspólnej Polityki Rolnej, jest główną determinantą rozwoju rolnictwa. Przeprowadzona analiza historycznoprawna oraz dogmatyczna pozwala zaobserwować, że kolejne reformy WPR od 1957 r. za główny cel rozwoju rolnictwa stawiały wzrost konkurencyjności zarówno wewnątrz Unii Europejskiej, jak i w stosunku do gospodarek rolnych innych państw. W obecnym oraz przyszłym okresie budżetowania 2021-2027 można zaobserwować odejście od realizacji celu konkurencyjności, jako priorytetu, na rzecz ochrony środowiska, klimatu, czy zachowania bioróżnorodności. To podejście pociąga za sobą zmianę rodzajów instrumentów prawnych, które służą do oddziaływania na konkurencyjność rolnictwa. Niesie za sobą zmianę paradygmatu współczesnego rolnictwa, gdzie dochód ma być tak samo ważny, jak czynniki środowiskowe, czy globalne. $\mathrm{W}$ tym zakresie podejście to nawiązuje do koncepcji własności rolniczej, sformułowanej w polskiej doktrynie prawa rolnego przez Andrzeja Stelmachowskiego, która przyznając rolnikowi prawa nakłada na niego także obowiązki. Współcześnie obowiązki te, wynikające $\mathrm{z}$ ochrony klimatu, zachowania bioróżnorodności, wymiany pokoleniowej w rolnictwie, zdrowia konsumenta, dobrostanu zwierząt, czy postępu technologicznego, są równie ważne, co ochrona własności, czy godziwy dochód dla rolnika. W tym zakresie rolnik ma nie tylko prawo do uzyskiwania pomocy 
od państwa, lecz także powinien ponosić odpowiednie ciężary związane ze szczególną funkcją w społeczeństwie. Znaczenia nabierają normy jakościowe, produkcja ekologiczna, czy też tzw. zdrowa żywność. Zmiany te wymuszają kształtowanie nowych instrumentów prawnych, które powinny być racjonalne i dostosowane do możliwości rolników.

3. Paradoksem jest, że instrumenty prawne WPR, mające poprawić konkurencyjność rolnictwa, jednocześnie naruszają konkurencyjność gospodarki w systemie wolnorynkowym. Pomoc publiczna, pochodząca od państwa, preferująca sektor rolny, stawia w gorszych warunkach konkurencyjnych pozostałe sektory gospodarki, które z tak znacznej pomocy nie mogą korzystać. Efekt ten można zaobserwować przy zmniejszającym się budżecie UE na rolnictwo. Regulacje wspólnotowe, wspierając konkurencyjność wewnętrzną rolnictwa, ograniczają jednocześnie konkurencyjność przemysłu, nauki itp. Oczywiście rolnictwo jest szczególną gałęzią gospodarki, która z uwagi na ograniczony zasób środków produkcji (w szczególności ziemi), zależność od czynników zewnętrznych (pogody) nie jest w stanie funkcjonować bez pomocy. Trzeba jednak wyważyć na ile pomoc przeznaczana na rolnictwo ingeruje w wolny rynek. W tym zakresie odpowiednie regulacje traktatowe wyraźnie stanowią o odpowiednim poziomie dopuszczalnej pomocy dla rolnictwa. Jednocześnie trzeba zauważyć, że rolnicy coraz ostrożniej korzystają z pomocy europejskiej ze względu na zwiększanie wymogów związanych z prowadzoną działalnością. Może się okazać w niedługiej przyszłości, że korzystniej dla nich będzie konkurować na wolnym rynku bez wsparcia finansowego, ale za to prowadząc intensywne, by nie powiedzieć przemysłowe, rolnictwo. Dlatego też wraz ze wzrostem wymagań dla rolników należy zwiększać pomoc finansową. Obecne tendencje niestety zakładają jej ograniczenie.

4. Prowadzony instytucjonalny rozdział środków przeznaczanych na rolnictwo wymaga udoskonalenia. Trudności proceduralne oraz skomplikowane rozwiązania prawne są zauważane już przez samego prawodawcę europejskiego. Jednym z głównych postulatów przyszłej WPR po 2020 r. jest jej uproszczenie. Wprowadzone liczne wymogi zarówno na etapie wnioskowania, realizacji, jak i rozliczania pomocy skutkują nie tylko niepewnością prawa, ale obniżeniem konkurencyjności rolnictwa. Rolnicy nie potrafią, albo bardzo często obawiają się wnioskować o pomoc, widząc wielość stawianych wymogów. Dotyczy to przede wszystkim „drobnych” rolników, których gospodarstwa są otoczone szczególną troską w polityce rolnej UE. Dlatego też w pracy zawarto postulaty nie tylko uproszczenia procedur związanych z podziałem środków, lecz także wskazano, które mechanizmy prawne się nie sprawdziły i nie doprowadziły do wzrostu konkurencyjności rolnictwa.

5. Instrumenty prawne oddziałujące na konkurencyjność rolnictwa mają niejednolity charakter, przez co czasami wzajemnie się wykluczają. Dzieje się tak, 
pomimo że normy prawne regulujące rozdział funduszy europejskich w sektorze rolnym są generalnie spójne. Spójność ta dotyczy regulacji krajowych z europejskimi. Natomiast bliższa obserwacja regulacji pozwala dostrzec sprzeczności na poziomie prawa europejskiego i krajowego w zakresie horyzontalnym. Ta obserwacja pozwoliła w pracy na dokonanie trzech podstawowych analiz. Jedną z nich była spójność regulacji polskich oraz europejskich. Sprawdzono dochowanie procedur legislacyjnych oraz zgodność poszczególnych przepisów prawa europejskiego z wymogami zawartymi w przepisach krajowych. Druga analiza dotyczyła badania zgodności regulacji polskich w sektorze rolnym w odniesieniu do innych regulacji prawa krajowego. Dostrzeżono tutaj niezgodności w zakresie recypowanych do prawa polskiego rozwiązań europejskich i istniejących rozwiązań polskich. Dotyczy to chociażby relacji rent strukturalnych z ubezpieczeniami społecznymi rolników, czy relacji rozporządzenia o jednolitej organizacji rynku rolnego i polskiej ustawy o organizacji niektórych rynków rolnych. Dostrzeżone nieścisłości w istotny sposób wpływają na konkurencyjność rolnictwa. Trzecia analiza to wewnętrzna spójność regulacji wewnątrz sektora rolnego w odniesieniu do rozdziału funduszy europejskich. Zbadano szereg rozbieżności pomiędzy niektórymi postanowieniami Programu Rozwoju Obszarów Wiejskich (PROW) a rozporządzeniami wykonawczymi, jak również wątpliwości interpretacyjne, wynikające z samych rozporządzeń. Wskazano w tym zakresie postulaty de lege ferenda, zarówno na możliwe rozwiązania o charakterze systemowym, jak też i bardzo szczegółowym. Mają one znaczenie nie tylko w aktualnie trwającej perspektywie finansowej, lecz także dla realizacji WPR po $2020 \mathrm{r}$.

6. Formalnoprawne procedury rozdziału środków pochodzących z funduszy europejskich są poprawnie przygotowane i co do zasady właściwie stosowane. Oznacza to, że na poziomie rozdysponowania środków europejskich przez państwa członkowskie nie dostrzeżono większych uchybień w relacji z przepisami unijnymi. Wskazano jednakże różnego typu możliwe nowe rozwiązania. Zaobserwowano także nieścisłości w zakresie zgodności, np. procedur uzyskiwania pomocy z PROW z innymi przepisami powszechnie obowiązującego prawa, w szczególności, co do zachowania poszczególnych jednolitości pojęć w prawie polskim i europejskim.

Praca jest podzielona na cztery rozdziały. Rozdział pierwszy zawiera analizę konkurencyjności jako terminu prawnego. Wskazuje, jak kluczowe jest rozumienie tego pojęcia w prawie dla określenia efektywności realizacji pomocy. Dotyczy ono także ewolucji rozumienia tego pojęcia w prawie europejskim i polskim. Teoretyczna analiza pojęcia konkurencyjności, poprzedzona kwerendą najważniejszych poglądów na istotę konkurencyjności jest przedmiotem rozdziału. Istniejące różne podejścia w określaniu konkurencyjności wskazały, że do badania konkurencyjności na obszarach wiejskich 
nie można użyć zawsze tej samej koncepcji i mechanizmów. Z uwagi na skomplikowaną i wieloraką materię, zastosowano w pracy różne podejścia w rozumieniu i analizie konkurencyjności. Szczególną uwagę zwrócono na powiązanie poszczególnych modeli konkurencyjności z konkretnymi instrumentami prawnymi.

W rozdziale drugim jest przedstawiona analiza Wspólnej Polityki Rolnej w zakresie zmian instrumentów prawnych, wpływających na konkurencyjność rolnictwa. Swoista ewolucja poszczególnych mechanizmów prawnych doprowadziła do stworzenia nowej jakości prawa, które w sposób bezpośredni i pośredni oddziałuje na konkurencyjność rolników zarówno wewnątrz, jak i na zewnątrz Unii Europejskiej. Dobierane mechanizmy prawne zależały od kształtowanej WPR. Zmieniające się cele tej polityki powodowały także różny poziom nasilenia wymogów związanych z konkurencyjnością.

W rozdziale trzecim zostały poddane analizie podstawy prawne dysponowania środkami europejskimi w zakresie rolnictwa. Poddano przeglądowi, analizie i ocenie akty prawa europejskiego oraz krajowego. Wyboru ich dokonano poprzez zdefiniowanie kryterium konkurencyjności.

W kluczowym dla rozprawy rozdziale czwartym przedstawiono na wybranych instrumentach prawych WPR, w tym przede wszystkim poszczególnych działań Programu Rozwoju Obszarów Wiejskich, aktualny stan rozdysponowania funduszy oraz główne problemy prawne. Przedstawiono mechanizmy o charakterze inwestycyjnym, społecznym i środowiskowym. Dokonano tego na polu zarówno regulacji oddziałujących na rynek rolny wewnątrz UE, jak i w zakresie norm handlu z państwami trzecimi.

W części kończącej wskazano postulaty de lege lata i de lege ferenda $\mathrm{w}$ zakresie zmian instrumentów prawnych WPR, mających wpływ na konkurencyjność polskiego rolnictwa.

Główny zakres informacji na temat krajowych regulacji dotyczących funduszy europejskich pochodzi zarówno ze źródeł prawa (akty normatywne - ustawy, rozporządzenia, zarządzenia itd.), jak również z orzecznictwa sądowego i źródeł poznania prawa (literatura, dorobek doktryny). Tematyka pracy prowadzi do posługiwania się metodą prawnoporównawczą w zakresie porównań prawodawstwa europejskiego i polskiego. W pracy zastosowano także metodę historycznoprawną, która ukazuje zmiany w prawie, jakie miały miejsce na przestrzeni ostatnich kilku lat. Metodę tę wykorzystano zarówno przy analizie pojęcia konkurencyjności w prawie, jak i przy prezentacji ewolucji WPR.

W pracy wykorzystano metodę dogmatycznej analizy prawa. Problematyka rozprawy koncentruje się wokół aktualnych rozwiązań ustawodawczych, przede wszystkim ciągle reformowanych instytucji prawnych. Prowadzone badania podlegały krytycznej analizie i wykładni powszechnie obowiązujących przepisów w zakresie wyznaczonym przez wskazane porządki prawne. Rozwiązanie postawionego problemu naukowego 
nastąpiło zatem poprzez analizę przyjętych unormowań oraz sformułowanie na tej podstawie postulatów de lege ferenda.

W aktualnie prowadzonych badaniach naukowych w unijnym i polskim prawie rolnym brakuje kompleksowej analizy prawnej, która uwzględniałaby ocenę instrumentów prawnych WPR, poprzez realizację celu wzrostu konkurencyjności. Przeprowadzona analiza ma zapełnić istniejącą lukę w badaniach w naukach prawnych, które uwzględniają ekonomiczne efekty oddziaływania prawa na otaczającą rzeczywistość.

W pracy do przeprowadzenia analizy wybrano tylko najważniejsze instrumenty polityki rolnej. Autorka w pełni zdaje sobie sprawę, że ocena wszystkich instrumentów prawnych w przedmiotowej rozprawie byłaby niemożliwa $\mathrm{z}$ dwóch powodów. Po pierwsze, do oceny niektórych instrumentów prawnych WPR brak jest narzędzi badawczych, które weryfikowałyby ich wpływ na konkurencyjność, czy nawet go uprawdopodobniały. Sama ta obserwacja powoduje, że instrumenty te raczej nie realizują celu zwiększania wydajności rolnictwa, z uwagi na niemierzalność ich efektów. Po drugie, analiza wszystkich dostępnych instrumentów prawnych WPR znacznie wykroczyłaby poza utylitarne cechy opracowania.

Praca przedstawia stan prawny na dzień 30 marca $2019 \mathrm{r}$.

Bibliografia pracy zawiera istotne podstawowe pozycje polskie i obcojęzyczne. Wykorzystana literatura obejmuje pozycje monograficzne, komentarze i artykuły. W opracowaniu przedstawiono także wiodące pozycje orzecznictwa Trybunału Sprawiedliwości oraz polskich sądów. 



\section{Rozdział 1}

\section{Konkurencyjność w nauce i prawie}

Konkurencyjność, a w szczególności dążenie do jej wzrostu, stała się motywem przewodnim polityki rolnej już od 1957 r. Zgodnie z art. 39 ust. 1 lit. a TFUE, zwiększenie wydajności stało się głównym celem polityki rolnej ${ }^{1}$. Kształtowane przez kolejne lata instrumenty prawne miały doprowadzić do równowagi ekonomicznej pomiędzy rolnictwem a innymi sektorami gospodarki. Zamierzenie to nie zostało zrealizowane, ponieważ nadal rolnictwo jest zajęciem mniej dochodowym, niż prowadzenie własnej działalności gospodarczej, czy praca zarobkowa w dużych miastach ${ }^{2}$.

Problemem jest samo rozumienie konkurencyjności jako kategorii prawnej. Aby móc ocenić, czy zwiększyła się wydajność gospodarstw, trzeba mieć narzędzia prawne i ekonomiczne ${ }^{3}$. Bez nich ocena będzie obarczona ryzykiem błędu. Poniżej zostaną zaprezentowane główne podejścia w rozumieniu konkurencyjności w nauce ekonomii oraz w nauce prawa. Przegląd najważniejszych podejść definicyjnych i wyodrębnienie czynników, które mają wpływ na konkurencyjność w rolnictwie pozwoli ocenić, czy stosowane instrumenty prawne WPR w pełni realizują cel zwiększania wydajności rolnictwa. Zawarty poniżej katalog ogranicza się do najważniejszych podejść naukowych i prawnych.

Bardzo ważnym elementem dalszych badań jest wyodrębnienie czynników, które będą wpływały na konkurencyjność rolnictwa. Zaliczono do nich przede wszystkim zasoby ziemi. To grunty rolne współcześnie nadal wyznaczają przyszłość dochodów rolniczych ${ }^{4}$. WPR zarówno w sferze dochodowej, jak i środowiskowej jest ukierunkowana na ochronę gruntów rolnych i zachowanie ich rolniczego charakteru. Wskazane w tym rozdziale inne czynniki wpływające na konkurencyjność również mają wpływ na dobór instrumentów prawnych do realizacji WPR.

1 Traktat o funkcjonowaniu Unii Europejskiej (Dz. U. z 2004 r. poz. 864/2 z późn. zm.).

2 A. Jurcewicz, Komentarz do art. 39 Traktatu o funkcjonowaniu Unii Europejskiej, [w:] Komentarz do Traktatu o funkcjonowaniu Unii Europejskiej, t. I (art. 1-89), D. Miąsik, N. Półtorak (red.), Warszawa 2012.

3 J. Goździewicz-Biechońska, The role of agriculture in the circular economy (perspectives for legislation and policy), „Przegląd Prawa Rolnego”, 2016, t. 18, nr 1, s. 81-96.

4 M. Soliwoda, J. Kulawik, J. Góral, Stabilizacja dochodów rolniczych: perspektywa międzynarodowa Unii Europejskiej i Polski, „Wieś i Rolnictwo”, 2016, nr 3. 


\subsection{Konkurencyjność w nauce i teorii}

Konkurencyjność jako kategoria naukowa jest analizowana wieloaspektowo. Opisywana jest przede wszystkim przez pryzmat nauk ekonomicznych, ale kryteria przedstawiające konkurencyjność można znaleźć praktycznie w każdej dziedzinie.

W naukach ekonomicznych konkurencyjność jest zagadnieniem złożonym. W ocenie konkurencyjności z jednej strony znaczenie mają podmioty kształtujące konkurencyjność gospodarki krajowej, a z drugiej - za istotne uznaje się znaczenie warunków otoczenia, w których funkcjonują podmioty, jako czynników oddziałujących na konkurencyjność tych podmiotów. W nauce dostrzega się tutaj występujące sprzężenie zwrotne, w którym konkurencyjność podmiotów wyznacza konkurencyjność kraju, natomiast konkurencyjność kraju wyznacza konkurencyjność podmiotów gospodarczych. Analizując konkurencyjność należy zdawać sobie sprawę z wieloaspektowości tego zagadnienia 5 .

To sprzężenie zwrotne jest zauważane również w analizie konkurencyjności w rolnictwie ${ }^{6}$. Wydajność gospodarcza rolników i ich dochodowość wyznacza konkurencyjność kraju. Natomiast konkurencyjność sektora rolnego jest wyznaczana przez pozycję danego państwa także $w$ innych sektorach, takich jak przemysł, czy transport. Analizując instrumenty prawne WPR, wpływające na konkurencyjność rolnictwa, nie można tego robić w oderwaniu od pozostałych gałęzi gospodarki. Przykładowo, fundusze przeznaczone na inwestycje drogowe na wsiach, niepochodzące z WPR, wpływają istotnie na poziom alokacji zasobów i wzrost dochodowości rolników.

Ta pierwsza obserwacja badawcza wpływa na konstrukcję dalszych analiz. Ocena efektywności prawnej i ekonomicznej poszczególnych instrumentów prawnych WPR nie może być czyniona w oderwaniu od analiz innych aktów prawnych, które bezpośrednio lub pośrednio oddziałują na konkurencyjność rolnictwa.

W tym zakresie najczęstszą postawą nauki, próbującą określić ramy konkurencyjności, jest odwołanie do znaczenia pojęcia konkurencji. Definiuje się ją jako proces, za pomocą którego uczestnicy rynku, dążąc do zaspokojenia swoich interesów, przedstawiają korzystniejsze od innych oferty pod względem ceny (konkurencja cenowa), jakości, albo innych charakterystyk (konkurencja pozacenowa), wpływających na decyzje o zawarciu transakcji. W tym zakresie konkurencyjność wpływa przede wszystkim na ceny lub inne pozacenowe czynniki. Konkurencja ${ }^{8}$ jest procesem, na który składa się wiele czynników. Dlatego też konkurencyjność w rolnictwie i ocena pojedynczych instrumentów prawnych napotyka trudności związane z oceną

5 W. Poczta, P. Siemański, Konkurencyjność rolnictwa polskiego po przystapieniu do Unii Europejskiej, Poznań 2010, s. 11.

6 W. Kleinhanss, Konkurencyjność głównych typów gospodarstw rolniczych w Niemczech, ,Zagadnienia Ekonomiki Rolnej”, 2015, nr 1, s. 25-41.

7 D.R. Kamerschen, R.B. McKenzie, C. Nardinelli, Ekonomia, Gdańsk 1991.

8 P. Czechowski, W. Ziętara, Konkurencja a regulacja w rolnictwie, Warszawa 1995. 
sektorową. Nie można dziś oceniać np. efektywności rent strukturalnych w oderwaniu od systemu płatności obszarowych, czy wsparcia dla młodego rolnika. Instrumenty te, pomimo że formalnie stanowią odrębne mechanizmy prawne, są ze sobą połączone w procesie inwestycyjnym i pomocowym.

Na konkurencyjność należy patrzeć jako na zjawisko wielorakie, na którego wpływ mają różne czynniki. Takie podejście powoduje powstawanie problemów badawczych w zakresie wyodrębnienia tylko jednego kryterium, według którego można oceniać efektywność. Dlatego też najczęstszym sposobem badania konkurencyjności jest ocena ex ante, a następnie ex post. Tak m.in. jest oceniania realizacja PROW jako mechanizmu, który służy w skali kraju do realizacji polityki rozwoju obszarów wiejskich. Wzbogaca się ją także o ocenę średniookresową, czy też analizę SWOT ${ }^{9}$. Tak wieloaspektowe podejście pozwala na zmianę odpowiednich strumieni finansowych i bieżące reagowanie na poszczególne zdarzenia ekonomiczne. Pozwala to również ocenić konkurencję zewnętrzną i wewnętrzną ${ }^{10} \mathrm{~W}$ perspektywie długo- i krótkookresowej.

Konkurencyjność jest ujmowana również jako konkretny stan - poziom konkurencji. Ten poziom jest jedną z właściwości określających konkurencyjnośćc ${ }^{11}$. Problemem jest tylko dobór momentu oceny konkurencyjności. Inaczej będzie ona wyglądała, kiedy dany instrument prawny będzie dopiero w początkowej fazie stosowania, a inaczej w sytuacji, kiedy środki będą rozliczane. W tym zakresie mogą w odniesieniu do jednego i tego samego mechanizmu prawnego występować różne poziomy konkurencyjności w odpowiednich okresach.

Należy też zwrócić uwagę, przez jakiego uczestnika rynku konkurencyjność jest oceniania. W tym samym czasie inaczej może być oceniana konkurencyjność podmiotów gospodarczych (rolników), sektorów gospodarek narodowych (rolnictwa), a jeszcze inaczej konkurencyjność krajów ${ }^{12}$ i regionów. Ocena ta dokonana w tym samym czasie może się różnić. Wspólna Polityka Rolna wydaje się te różnice dostrzegać i przewiduje pewne instrumenty wsparcia dla obszarów, które mogą ze względu na swoje właściwości naturalne być w gorszej pozycji konkurencyjnej. Dla przykładu można wskazać tylko wsparcie dla obszarów o niekorzystnych warunkach gospodarowania (ONW), czy obszarów cennych przyrodniczo jako obszary Natura 2000. Ocena stosowania tych instrumentów musi brać pod uwagę szerszy kontekst przyrodniczy. Dlatego podkreślić jeszcze raz należy, że konkurencyjność jest zjawiskiem złożonym,

9 Analiza SWOT stanowi podstawową metodę analizy strategicznej przedsiębiorstwa. Nazwa metody jest akronimem angielskich słów: strengths (mocne strony), weaknesses (słabe strony), opportunities (szanse potencjalne lub zaistniałe w otoczeniu), threats (zagrożenia prawdopodobne lub istniejące w otoczeniu).

10 A. Woś, Konkurencyjność potencjalna polskiego rolnictwa, Warszawa 2001.

11 H. Adamkiewicz, Uwarunkowania konkurencyjności przedsiębiorstw w gospodarce rynkowej, Gdynia 1999, s. 5 i nast.

12 M. Gorynia, Innowacyjność, produktywność i konkurencyjność gospodarki a międzynarodowa wspótpraca gospodarcza, ,Ruch Prawniczy, Ekonomiczny i Socjologiczny”, 2018, z. 4, s. 209-228. 
gdzie wskazanie tylko jednej wyłącznej przyczyny, a nie osiągnięcia zakładanych celów może wydać się dość trudne.

Konkurencyjność gospodarki w nauce jest formułowana przez określenia związane $\mathrm{z}$ teorią wymiany międzynarodowej oraz teorie, mające charakter ogólnych albo odcinkowych efektów osiąganych ${ }^{13}$ przez gospodarkę narodową, posiadające swoje źródło w teorii wzrostu, albo w rozwoju gospodarczym ${ }^{14}$.

W teoriach wymiany międzynarodowej pojęcie konkurencyjności wiąże się z korzyściami uzyskiwanymi z handlu międzynarodowego, a sama konkurencyjność rozumiana jest jako umiejętność utrzymywania lub zwiększania udziałów rynkowych w wymianie rynkowej. Badacze skupiają się na analizie udziałów w rynku, tzn. na poziomie oraz dynamice zmian, penetracji importowej i eksportowej15. WPR w tym zakresie posiada szereg instrumentów w zakresie organizacji jednolitego wspólnego rynku. Można tu wyróżnić mechanizmy czysto interwencyjne, takie jak ceny, czy kontyngenty, po subsydiowanie importu i eksportu. Niewątpliwie poddane w kolejnych rozdziałach instrumenty prawne dotyczą podnoszenia konkurencyjności produktów europejskich eksportowanych poza Unię Europejską oraz ochrony własnego rynku od konkurencyjnych produktów importowanych.

Konkurencyjność rozumiana jako utrzymywanie lub zwiększanie udziałów rynkowych w wymianie rynkowej jest w sferze rolnej najbardziej wyeksponowana ze wszystkich wspólnotowych rynków. Zachowania związane z utrzymaniem poziomu konkurencyjności rynku europejskiego można było zaobserwować przy negocjacjach takich umów, jak TTIP ${ }^{16}$ czy CETA ${ }^{17}$, a ostatnio umów handlowych UE z Japonią ${ }^{18}$. Zasada preferencji europejskiej jest jednym z fundamentów funkcjonowania wspólnego rynku rolnego. Rynek europejski, w szczególności w sektorze rolnym podlegał wieloaspektowej analizie zmierzającej do protekcjonistycznej ochrony ${ }^{19}$. To właśnie

13 R. Harasym, R. Pater, T. Skica, Konkurencyjność i rozwój Polski Wschodniej, „Samorząd Terytorialny", 2018, nr 5, s. 64-76.

14 M. Lubiński, Konkurencyjność gospodarki. Pojęcie i sposób mierzenia, [w:] Międzynarodowa konkurencyjność gospodarki Polski - uwarunkowania i perspektywy. Raporty. Studia nad konkurencyjnościa, Warszawa 1995.

15 W. Poczta, P. Siemański, Konkurencyjność..., dz. cyt., s. 12.

16 Transatlantyckie Partnerstwo w dziedzinie Handlu i Inwestycji (ang. Transatlantic Trade and Investment Partnership, TTIP).

17 Kompleksowa Umowa Gospodarczo-Handlowa (Comprehensive Economic and Trade Agreement, CETA); P. Wojciechowski, Nadzór nad żywnościa GMO w kontekście umowy CETA, „Bezpieczeństwo i Higiena Żywności”, 2016, nr 4.

18 EU-Japan Economic Partnership Agreement, http://trade.ec.europa.eu/doclib/press/index.cfm?id $=1684$ [data dostępu 6 marca 2019 r.].

19 Por. wyrok TS z dnia 11 czerwca 1985 r. w sprawie 288/83 Komisja Wspólnot Europejskich przeciwko Irlandii, Zb. Orz. 1985, s. 1761; wyrok TS z 10 października 1973 r. w sprawie 34/73 Fratelli Variola S.p. a przeciwko Administrazione italiana delle Finanze, Zb. Orz. 1973, s. 981; wyrok TS z dnia 5 marca 1996 r. w połączonych sprawach C-46/93 i C-48/93 Brasserie du Pêceur SA przeciwko Bundesrepublik Deutschland i The Queen przeciwko Secretary of State for Transport, ex parte: Factorame Ltd. i innym, 
ochrona własnego rynku przed towarami z USA ${ }^{20}$ czy Kanady stała się przyczyną długich negocjacji tych umów. Różnic nie należy upatrywać tylko w pozycji ekonomicznej stron poszczególnych umów, ale przede wszystkim w różnym podejściu prawnym do własnego rynku. Sztandarową kwestią sporną pozostawało przede wszystkim wprowadzanie do obrotu produktów rolnych genetycznie modyfikowanych. Odmienne instrumenty prawne stosowane w państwach Ameryki Północnej i w Europie bezpośrednio kształtują konkurencyjność tych sektorów. Ostatecznie nie podpisano umowy z USA, a umowa z Kanadą podlega wdrożeniu. Jej efekty, zostaną zauważane pewnie za kilka lat i będą bezpośrednio oddziaływać na konkurencyjność rolnictwa każdego z państw członkowskich.

W kolejnym podejściu do konkurencyjności znaczenie mają przede wszystkim zasoby czynników produkcji, poziom efektywności wykorzystania czynników produkcji, a także tempo i kierunek zmian strukturalnych oraz skuteczność, będącą w związku z teorią rozwoju gospodarczego. Zofia Wysokińska wskazuje, iż konkurencyjność to efektywne wykorzystywanie zasobów czynników produkcji, a także zmiany strukturalne zachodzące $\mathrm{w}$ gospodarce, które prowadzą do zwiększenia efektywności gospodarowania ${ }^{21}$. Oznacza to konieczność wykorzystywania dostępnych środków produkcji do podnoszenia konkurencyjności rolnictwa. WPR w tym zakresie stara się wspierać te najważniejsze czynniki produkcji, takie jak ziemia, czy praca rolników. W najnowszych podejściach do realizacji modelu rolnictwa europejskiego jednym z czynników rozwojowych ma być docenienie innowacyjności.

Czynnikiem produkcji ma się stać know-how na podniesienie jakości produkcji, a także w związku z malejącą liczbą pracowników w sektorze rolnym, wprowadzenie większej technicyzacji rolnictwa. Niewątpliwie te czynniki produkcji, aby wpłynąć na konkurencyjność, muszą być dostosowane do przemian strukturalnych w całej gospodarce. Obecnie można zaobserwować opóźnienie w zakresie wprowadzania nowoczesnych maszyn do masowej produkcji rolnej. Większość gospodarstw rolnych korzysta z urządzeń, które nie spełnią już nowych wymogów. Dlatego innowacyjność, robotyka i zautomatyzowanie produkcji rolnej będzie jednym z kluczowych czynników produkcji, wpływających na podniesienie poziomu konkurencyjności22.

Z oceną czynnika ludzkiego wiąże się podejście Kazimierza Meredyka, który wskazuje, że konkurencyjność jest właściwością wzrostu gospodarczego i wynika

Zb. Orz. 1996, s. I-1029; wyrok TS z dnia 20 kwietnia 1978 r. w połączonych sprawach 80 i 81/77 Société Les Commissionnaires Réunis SARL przeciwko Receveur des douanes; SARL Les fils de Henri Ramel przeciwko Receveur des douanes, Zb. Orz. 1978, s. 927.

20 K. Marciniuk, Problematyka rolna $w$ świetle nowej umowy handlowej UE-USA (Transatlantic Trade \& Investment Agreement), „Studia Iuridica Agraria”, Białystok 2013, t. 11, s. 227-241; M. Janowicz-Lomott, K. Łyskwa, Wspieranie rolnictwa w USA z wykorzystaniem instrumentów ubezpieczeniowych (FARM BILL 2014), „Studia Oeconomica Posnaniensia”, 2015, t. 3, nr 123.

21 Z. Wysokińska, Konkurencyjność w międzynarodowym, globalnym handlu technologiami, Warszawa 1999.

22 J. Bieluk, Zmiana paradygmatu prawa rolnego, ,Studia Iuridica Agraria”, Białystok 2015, t. 13. 
bezpośrednio z ilości oraz jakości pracy ${ }^{23}$. Niewątpliwie poprawa jakości pracy powinna podnosić poziom konkurencyjności. W WPR wiąże się z tym pomoc dla młodych rolników oraz zaprzestanie dotowania prowadzenia działalności rolniczej przez osoby starsze. Temu służą instrumenty prawne z zakresu pomocy dla młodych rolników, czy do niedawna renty strukturalne. Oczywiście, z poprawą jakości pracy wiąże się także finansowanie szkoleń, przekwalifikowanie się rolników, czy też przeorientowanie kierunków produkcji.

Niewątpliwie jednym z ważnych czynników wpływających na konkurencyjność rolnictwa jest jakość produktów rolnych i żywnościowych. W literaturze przedmiotu podkreśla się, że „konkurencyjność opiera się w coraz większym stopniu przede wszystkim na dwóch wzajemnie powiązanych filarach, efektywności i jakości. Nie trzeba bowiem szeroko uzasadniać, że jakość produktów warunkuje nie tylko możliwość zbytu, ale i cenę"24. $Z$ tych też względów jakość produktów, a przede wszystkim produktów ekologicznych ${ }^{25}$, jest szczególnie wspierana w polityce rolnej Europy. Służą temu nie tylko celowane w ten sektor dotacje, ale także cały system instrumentów prawnych, związanych z kontrolą jakości produktów rolnych i żywnościowych. Niezachowanie jakości produktów, czy też nieuczciwe praktyki producentów, wpływające na jakość produktów, skutkują brakiem zaufania do danego produktu, a w efekcie do obniżeniem jego konkurencyjności.

Dość jaskrawym przykładem oddziaływania jakości produktu na konkurencyjność jest szeroko opisywana w mediach działalność jednej z ubojni w Polsce, która z chęci zysku doprowadzała do wprowadzania na rynek wołowiny pochodzącej z bydła padłego lub chorego. Ujawniony proceder zachwiał zaufaniem konsumentów co do jakości tego produktu i drastycznie obniżył sprzedaż wołowiny. Takie jednostkowe przypadki, które świadczą o nierespektowaniu jakości produktów rolnych, właściwie spowodowały zniszczenie konkurencyjności polskiej wołowiny. Ten bieżący i głośny przykład jest tylko egzemplifikacją wpływu kryteriów jakościowych na konkurencyjność rolnictwa. Stosowane współcześnie instrumenty prawne kontroli jakości oraz produkcji rolnej w zgodzie $\mathrm{z}$ ochroną środowiska wydają się sprzyjać wzmacnianiu konkurencyjności rolnictwa poprzez podnoszenie jakości produktów rolnych. Ze względu na fakt, iż tylko gospodarka posiadająca potencjał rozwojowy może stać się konkurencyjna w perspektywie długookresowej, dlatego konkurencyjność w ujęciu ogólnym powinna utożsamiać się z bodźcami wzrostu gospodarczego.

Michael E. Porter, autor jednej z podstawowych teorii (model tzw. „diamentu” Portera), wyróżnił cztery podstawowe czynniki uzyskania przewagi konkurencyjnej:

${ }^{23}$ K. Meredyk, Przesłanki wzrostu konkurencyjności gospodarki polskiej, [w:] Konkurencyjność gospodarki Polski w dobie integracji z UE i globalizacji, J. Bossak, W. Bieńkowski (red.), Warszawa 2001.

24 M. Słodowa-Hełpa, Wieś i rolnictwo w regionalnych i lokalnych strategiach rozwoju, [w:] Wieś i rolnictwo $w$ procesie integracji w UE, E. Kośmicki, H. Januszek, W.L. Janik (red.), Poznań 1998.

25 B. Jeżyńska, Proekologiczne instrumenty wsparcia zrównoważonego rozwoju obszarów wiejskich, „Studia Iuridica Agraria”, Białystok 2012, t. 10, s. 251-264. 
czynniki produkcji, warunki popytu, branże powiązane i wspierające oraz strategie firm i strukturę branży oraz konkurentów ${ }^{26}$. Co prawda, czynniki te znajdują zastosowanie przede wszystkim do oceny konkurencyjności przedsiębiorstw, ale można zastosować je per analogiam także do analiz w sektorze rolnym²7.

Z punktu widzenia celów pracy czynniki wyróżnione przez Portera odgrywają ważną rolę w określeniu przewagi konkurencyjnej rolnictwa. Stąd należy wskazać, iż warunki wynikające z czynników produkcji to: jakość kapitału ludzkiego, osiągalne zasoby, technologie oraz infrastruktura ${ }^{28}$. Wszystkie te cztery czynniki w większym lub mniejszym stopniu znajdują swoje odzwierciedlenie w określaniu instrumentów WPR, które mają wspierać konkurencyjność. Tytułem przykładu można wskazać, że jakość kapitału ludzkiego jest wspierana przez system doradztwa rolniczego. Osiągalne zasoby - przykładowo ziemia jest chroniona przepisami dotyczącymi zachowania bioróżnorodności. Technologie, czy innowacje ${ }^{29}$ stają się współcześnie czynnikiem determinującym rozwój rolnictwa. W końcu infrastruktura jest wspierana chociażby przez działania modernizacji gospodarstw rolnych, czy procesy scaleniowe. Czynniki popytowe określają naturę popytu lokalnego, w szczególności rozmiary rynku lokalnego. W tym zakresie to rynek lokalny i lokalni producenci uzyskują większe wsparcie.

M.E. Porter wskazuje również jako kolejny czynnik, mający wpływ na konkurencyjność, strukturę danej branży w kontekście branż wspomagających i powiązanych ${ }^{30}$. W tym zakresie w kontekście europejskim można wyróżnić strukturę całego rolnictwa, ale także rolnictwo w poszczególnych państwach członkowskim. Ono od siebie się znacznie różni. Stosowane instrumenty prawne wspierające np. produkcję wina będą inaczej funkcjonowały w Polsce, a inaczej we Francji ${ }^{31}$.

Dobór instrumentów prawnych dla polskiego rolnictwa musi być podyktowany oceną ekonomiczną, demograficzną, rozwojową i technologiczną. Wybieranie tylko poszczególnych instrumentów prawnych bez ich umiejscowienia w całym sektorze polskiego rolnictwa, może być nie tylko marnowaniem środków finansowych, lecz także może oddziaływać kontrefektywnie na konkurencyjność rolnictwa.

26 M.E. Porter, The Competitive Advantage of Nations, New York 1990, za: R.J. Stimson, R.R. Stough, R.H. Roberts, Regional Economic Development. Analysis and Planning Strategy, Berlin 2006, s. 207.

27 A. Judzińska, Instrumenty wsparcia rolnictwa $w$ ramach WPR, [w:] Wplyw Wspólnej Polityki Rolnej na rolnictwo, W. Łopaciuk (red.), Warszawa 2011.

28 M.E. Porter, The Competitive..., dz. cyt., s. 207.

29 J. Kulawik, Regulacje środowiskowe i innowacje a konkurencyjność, „Zagadnienia Ekonomiki Rolnej”, 2016, t. 346, nr 1, s. 3-21.

30 I. Srivastara, S.S. Batie, P.E. Norris, The Porter Hypothesis, Property Rights, and Innovation Offstets: The Case of Southwest Michigan Pork Producer, Submitted for the Annual Meeting of the American Agricultural Economic Association, Nashville, Tennesse, August 8-11 1999.

31 Reforma wspólnej organizacji rynku wina - dotychczasowe postęy (przedstawione na mocy art. 287 ust. 4 akapit drugi TFUE), Sprawozdanie specjalne, Europejski Trybunał Obrachunkowy, $2012, \mathrm{nr} 7$. 
Do cech istotnych poprawiających konkurencję można zaliczyć także stopień powiązań pomiędzy poszczególnymi podmiotami ${ }^{32}$. Wbrew pozorom, powstanie odizolowanych gospodarczo podmiotów czy całych branż nie wpływa na poprawę konkurencyjności danego sektora. W tym zakresie stworzono instrumenty prawne, mające za zadnie sprzyjać współpracy rolników. Służą temu przede wszystkim takie działania jak pomoc dla grup producentów rolnych, czy promocja produktów rolnych. Niewątpliwie rolnicy muszą współpracować z branżą przetwórców i sprzedawców detalicznych. Na tym polu pozostaje jeszcze wiele do zrobienia. Samo doskonalenie chociażby umowy kontraktacji ${ }^{33}$ może okazać się nieskuteczne. Potrzeba wypracowania mechanizmów prawnych, które będą zabezpieczać rolników w negocjacjach z dużymi koncernami i nie pozwolą wykorzystać ich pozycji dominującej.

Jednym z ostatnich czynników wskazanych przez M.E. Portera jest wyodrębnienie impulsu rozwojowego danej branży w postaci strategii firm ${ }^{34}$, struktury branży ${ }^{35}$ i licznych konkurentów ${ }^{36}$. Występowanie tych czynników pozwala na poprawę konkurencyjności, jeżeli oczywiście te czynniki są efektywnie wykorzystywane. Realizacja tego czynnika przejawia się w szeregu instrumentów prawnych, mających wpływ na konkurencyjność rolnictwa. Należy przede wszystkim wskazać, że ubiegając się o pomoc inwestycyjną rolnicy są zobowiązani do określenia biznesplanów (planów rozwoju gospodarstwa) ${ }^{37}$. Precyzują w nim nie tylko strategię swojej działalności, ale także określają swoją pozycję na rynku względem podmiotów konkurujących. Sama ta ocena pozwala na racjonalne określenie możliwości konkurencyjnych danego rolnika. Umożliwia również ocenę celowości pomocy finansowanej ze środków publicznych. W końcu na rozliczeniu środków istnieje możliwość oceny ex ante i ex post podję-

32 M.E. Porter, A. Nicholas, A. McGahan, An Interview with Michael Porter, „The Academy of Management Executive (1993-2005)", 2020, s. 43-52.

33 B. Zdziennicki, Umowa kontraktacji, [w:] Prawo rolne, P. Czechowski (red.), Warszawa 2017, s. 511-515; A. Stelmachowski, Kontraktacja, [w:] System prawa prywatnego, t. 7: Prawo zobowiazań, J. Rajski (red.), Warszawa 2004; A. Stelmachowski, B. Zdziennicki, Prawo rolne, Warszawa 1987, s. 115 i nast.; B. Zdziennicki, Kontraktacja produktów rolnych. Funkcje, problemy organizacyjne, Warszawa 1975; I. Lipińska, Kontraktacja jako ogniwo tańcucha agrologistycznego, „Logistyka”, 2012, z. 4; B. Zdziennicki, Kierunki usprawnień organizacyjnych kontraktacji produktów rolnych, Warszawa 1976; D. Łobos-Kotowska, Wspótczesne funkcje umowy kontraktacji, [w:] Wspótczesne problemy prawa rolnego i cywilnego. Księga jubileuszowa Profesor Teresy Kurowskiej, D. Łobos-Kotowska, P. Gała, M. Stańko (red.), Warszawa 2018; A. Stelmachowski, Kontraktacja produktów rolnych, Warszawa 1960; K. Leśkiewicz, I. Lipińska, Prawne aspekty kwalifikacji stosunku prawnego jako umowy kontraktacji w świetle orzecznictwa sądów powszechnych, „Studia Iuridica”, 2016, t. 66.

34 M.E. Porter, Competitive advantage: Creating and sustaining superior performance, New York 2008.

35 M.E. Porter, V.E. Millar, How information gives you competitive advantage, New York 1985.

36 M.E. Porter, M.R. Kramer, The link between competitive advantage and corporate social responsibility, „Harvard Business Review”, 2006, nr 84, s. 78-92.

37 M. Milewska, Pomoc publiczna w rolnictwie - wybrane aspekty, „Acta Scientiarum PolonorumOeconomia", 2009, nr 8. 
tych działań. Rolnik sam może ocenić swoją pozycję konkurencyjną na rynku i efekty podejmowanych przedsięwzięć inwestycyjnych.

Opisany dobór czterech czynników i system zależności pomiędzy nimi pozwala na określenie pozycji konkurencyjnej danej branży (w tym sektora rolnego), a także na wskazanie możliwych udoskonaleń w każdym z czynników, co powinno pozytywnie wpłynąć na konkurencyjność danej branży ${ }^{38}$. Zasygnalizowane oddziaływanie poszczególnych czynników pokazuje, że nie istnieje jeden dominujący czynnik, który rozstrzyga o przewadze konkurencyjnej. Dopiero współwystępowanie wszystkich zależności może doprowadzić do określenia konkurencyjności rolnictwa, a co za tym idzie umożliwić ocenę jego wzrostu. Należy o tym pamiętać analizując kolejne instrumenty prawne, mające pomóc rolnikom. Wydaje się już na tym wstępnym etapie rozważań, że brak podejścia horyzontalnego, które uwzględniałoby wszystkie czynniki wpływające na konkurencyjność, jest jedną z wad konstruowanych mechanizmów prawnych WPR.

M.E. Porter wyszczególnia również dodatkowe dwa czynniki: szanse, rozumiane jako potencjał umożliwiający poprawę zdolności konkurencyjnej, oraz rząd (w tym także lokalny), który ma możliwość stworzenia środowiska sprzyjającego poprawie konkurencyjności ${ }^{39}$. Niewątpliwie posiadany potencjał, czy to naturalny, czy też inny, ma znaczny wpływ na konkurencyjność rolnictwa. Czynnikiem trudnym do oceny jest polityka i klimat wokół niej stwarzany przez rządy państw członkowskich oraz władze samorządowe. Tam, gdzie władza jest nastawiona na dialog z obywatelami, gdzie wsłuchuje się w ich potrzeby można zaobserwować szybszy postęp, a co za tym idzie zwiększenie poziomu konkurencyjności.

W polskiej nauce Wojciech Bieńkowski przez konkurencję rozumie „taki stan (kondycja) gospodarki, kiedy dany kraj może w warunkach wolnego i uczciwego rynku produkować dobra i usługi, które sprostają wymogom rynku międzynarodowego, a jednocześnie zachowa lub podniesie dochody realne swoich obywateli" 40 . Zaprezentowana definicja wydaje się niezwykle przydatna i mająca zastosowanie dla dalszych analiz, jako że najtrafniej odpowiada istocie prowadzenia strategicznej polityki rozwoju regionalnego ${ }^{41}$. Rozwój ten zakłada nie tylko zwiększenie poziomu konkurencyjności rolnictwa, jako sektora gospodarki, lecz także podniesienie dochodów poszczególnych rolników. Dopiero synergia tych dwóch czynników może pozwolić na ocenę konkurencyjności rolnictwa.

38 J.N. Foss, Research in strategy, economics, and Michael Porter, „Journal of Management Studies", 1996, nr 33, s. 1-24.

39 M. E. Porter, The Competitive..., dz. cyt., s. 207.

40 W. Bieńkowski, Reaganomika i jej wpływ na konkurencyjność amerykańskiej gospodarki, Warszawa 1995, s. 28.

41 Klastry w strategii rozwoju konkurencyjności na Mazowszu, A.Z. Nowak (red.), Warszawa 2009, s. 36. 
W nauce jest prezentowane także rozumienie konkurencyjności, w którym „gospodarka konkurencyjna to taka, która w dłuższym okresie, na tle innych krajów osiąga wyższą dynamikę wzrostu gospodarczego, poziom zatrudnienia i zwiększa poziom życia swoich obywateli szybciej niż inne kraje [...]. To również gospodarka, która umacnia swoją pozycję i wpływ na międzynarodowe stosunki ekonomiczne"42. W tym zakresie porównuje się konkurencyjność gospodarek i sektorów w poszczególnych państwach. Najtrudniejszym problemem wydaje się być znalezienie mierników, które skutecznie będą mogły służyć do oceny konkurencyjności. Każdy z nich ma swoje wady i zalety.

Zgodnie z European Competitiveness Report ${ }^{43}$ z 2001 roku za gospodarkę konkurencyjną uważa się taką gospodarkę, w której społeczeństwo jest w stanie utrzymać długotrwały, wysoki oraz rosnący standard życia, wysoki poziom zatrudnienia, zakładając jednocześnie równowagę bilansu płatniczego i brak zagrożenia dobrobytu kolejnych pokoleń. Definicja ta znajduje zastosowanie w przypadku obserwacji długofalowych działań ekonomicznych. Do zastosowania oceny poziomu konkurencyjności danego sektora należy uwzględnić nie tylko takie mierniki, jak poziom zatrudnienia, czy równowagę bilansu płatniczego, lecz także dość trudny w jednoznacznej ocenie dobrobyt przyszłych pokoleń. $Z$ tego też względu stosowanie tej definicji może okazać się problematyczne.

Poddając analizie zagadnienie konkurencyjności należy podkreślić, iż jest ona kategorią wartościującą, opisującą stan do którego się dąży ${ }^{44}$. Takie wartościowanie służy nie tylko tworzeniu rankingów, ale również budowaniu mechanizmów, które sprawdziły się w państwach o wysokim poziomie konkurencyjności i przenoszeniu ich do państw, gdzie takiej konkurencji nie ma. Zatem konkurencyjność, niezależnie czy rozważana w aspekcie gospodarki krajowej, pozycji międzynarodowej, czy analizując sektor czy region stanowi stan pożądany. Brak konkurencji prowadzi do monopolu, który w świetle teorii wolnego rynku nie powinien mieć miejsca.

Przedstawione powyżej teorie nie wyczerpują pełnego katalogu teorii konkurencyjności. $Z$ uwagi na zakres pracy, jakim jest analiza instrumentów prawnych wpływających na konkurencyjność polskiego rolnictwa prezentowane teorie skłaniają do skupienia uwagi na tym aspekcie. Przedstawione teorie uwzględniają możliwość przeprowadzenia badań dotyczących kształtowania i efektywności poszczególnych mechanizmów WPR.

O konkurencyjności polskiego rolnictwa decyduje efektywność wykorzystania potencjału produkcyjnego determinowana strukturami produkcyjnymi, a także sposobnością lokowania części produkcji na rynkach zagranicznych. Nie bez znaczenia

42 J. Bossak, Międzynarodowa konkurencyjność gospodarki polskiej - ujęcie instytucjonalne, [w:] H. Podedworny, J. Grabowiecki, H. Wnorowski, Konkurencyjność gospodarki polskiej a rola państwa przed akcesja do Unii Europejskiej, Białystok 2000.

43 European Competitiveness Report, European Commission, Luxemburg 2001.

44 W. Poczta, P. Siemański, Konkurencyjność..., dz. cyt., s. 13. 
pozostaje tutaj pomoc finansowa, pochodząca $\mathrm{z}$ budżetu unijnego oraz pomoc publiczna państwa. Dopiero uwzględnienie tych wszystkich czynników rozstrzyga o poziomie konkurencyjności polskiego rolnictwa. UE dąży do harmonizacji rolnictwa i dlatego konkurencyjność staje się niezwykle istotna, „o randze zagadnienia konkurencyjności polskiego sektora żywnościowego, w tym rolnictwa, świadczy najlepiej fakt, że taki warunek postawiła Unia Europejska wszystkim krajom ubiegającym się o członkostwo, aby po akcesji mogły skuteczniej przeciwstawiać się konkurencji rynkowej Wspólnoty"45. Konkurencyjność polskiego rolnictwa stanowi potencjał dla rozwoju kraju. Zgodne są poglądy, iż w tym aspekcie przed polskim rolnictwem stoi wiele wyzwań ponieważ „, procesie kształtowania konkurencyjności polskiej gospodarki najsłabsze ogniwo stanowi właśnie rolnictwo, wymagające daleko idącej przebudowy"46.

\subsection{Zasoby a konkurencyjność rolnictwa w Polsce}

Jednym z ważniejszych czynników wpływających na konkurencyjność rolnictwa jest dostęp do zasobów ${ }^{47}$. Państwa i gospodarki, który taki dostęp posiadają w większym zakresie niewątpliwie zwiększają swoją konkurencyjność. Ważnym czynnikiem jest również umiejętne wykorzystanie zasobów oraz dostosowanie $\mathrm{z}$ ich korzystania $\mathrm{w}$ procesie zmian.

Do zasobów i ich optymalnej alokacji odwołuje się także art. 39 ust. 1 lit. a Traktatu o funkcjonowaniu Unii Europejskiej wskazując, że celem WPR jest ,zwiększenie wydajności rolnictwa przez wspieranie postępu technicznego, racjonalny rozwój produkcji rolnej, jak również optymalne wykorzystanie czynników produkcji, zwłaszcza siły roboczej"48. Te czynniki mają doprowadzić do wzrostu konkurencyjności.

Poniższa analiza najważniejszych zasobów z punktu widzenia rolnictwa jest jednocześnie zobrazowaniem kierunków wsparcia WPR. Wychodząc od podstawowego dla rolnictwa czynnika produkcji, jakim jest ziemia - zarówno początkowo, jak i współcześnie dotacje dla zachowania rolnego charakteru ziemi były i są znaczące. Dbanie o zasoby ziemi staje się jednym z głównych wyznaczników polityki rolnej w Europie. Przejawia się ono nie tylko poprzez kolejne środki finansowe, ale także w aktach prawnych, które zmierzają do zachowania rolnego charakteru ziemi i zapobieżeniu nadmiernym procesom urbanizacji oraz spekulacji gruntami.

45 M. Słodowa-Hełpa, Konkurencyjność - główne wyzwanie dla polskiego sektora rolno-żywnościowego w zintegrowanej Europie, [w:] Rolnictwo polskie we Wspólnej Polityce Rolnej Unii Europejskiej, Z.W. Puślecki, M. Walkowski (red.), Poznań 2004.

46 M. Słodowa-Hełpa, Konkurencyjność..., dz. cyt., Poznań 2004.

47 O. Stefko, Podstawowe zasoby gospodarstwa rolniczego i ich zagospodarowania, [w:] Podstawy wiedzy o rolnictwie i agrobiznesie, M. Kozera, R. Ryś-Jurek, M. Tabert (red.), Poznań 2012.

48 Traktat o funkcjonowaniu Unii Europejskiej (Dz. U. z 2004 r. poz. 864 z późn. zm.). 
Ważnym zasobem, który wpływa na konkurencyjność jest także dostęp do zasobów pracy. To od liczby rolników oraz od struktury wiekowej, a także wykształcenia zależy jakość produkcji oraz jej efektywność. Dlatego też szereg instrumentów WPR jest ukierunkowana na rozwój młodych rolników, na ich dokształcanie. Pomoc jest przeznaczana także na przekwalifikowanie, czy w niektórych przypadkach zaprzestanie działalności rolniczej. Określenie wielkości zasobów pracy w rolnictwie staje się kluczowym wyzwaniem w szczególności w perspektywie zmniejszającej się liczby rolników aktywnych zawodowo.

Ważnym zasobem jest struktura produkcji rolnej, dostępność do środków trwałych, czy ostatnio efektywność wykorzystywania innowacji w działalności rolniczej. Zasoby te zostaną poddane tylko wybranej analizie wskaźnikowej, z uwagi na prawny charakter badań. Jednocześnie nie można pominąć ścisłego powiązania przyjmowanych rozwiązań legislacyjnych z analizą efektów ekonomicznych.

Efektywna alokacja zasobów to podstawowy problem ekonomii ${ }^{49}$. Połączenie wszystkich zasobów i racjonalne ich współdziałanie może przynieść dopiero zamierzone efekty. Samo posiadanie zasobów bez umiejętności ich wykorzystania nie będzie podnosiło poziomu konkurencyjności.

Poniższa analiza przedstawia tylko najważniejsze zasoby, uwzględniając wielkość kierowanych środków pomocowych oraz wagę ich alokacji dla rozwoju rolnictwa. Pozostałe zasoby występujące w mniejszych ilościach są także ważne, ale ich poziom wsparcia nie jest aż tak znaczny. Badając konkurencyjność alokacji zasobów, główną uwagę zwraca się na wyposażenie rolnictwa w zasoby produkcyjne odnośnie co do ilości oraz jakości, a także bada się struktury rolne oddziałujące na wykorzystany potencjał produkcyjny wyrażany przez zasoby ${ }^{50}$. Niewątpliwie każdy PROW rozpoczyna się od analizy dostępności zasobów. Ich identyfikacja determinuje dobór poszczególnych instrumentów prawnych.

Prawo odgrywa istotną rolę $\mathrm{w}$ procesach relacji pomiędzy zasobami a konkurencyjnością.

\subsubsection{Zasoby ziemi}

Ziemia jest podstawowym zasobem, który determinuje konkurencyjność rolnictwa oraz jego rozwój ${ }^{51}$. Dostęp do dobrej jakości nieruchomości rolnych, o wysokiej klasyfikacji gleboznawczej jest wyznacznikiem możliwości produkcyjnych. Zasób ziemi zostanie jednakże optymalnie wykorzystany, gdy będzie odpowiednio chroniony nie tylko przed ingerencją intensywnego rolnictwa, lecz także przed przeznaczaniem go na cele inne niż rolnicze. W tym zakresie wypracowuje się szereg mechanizmów

\footnotetext{
49 T. Przybyciński, Polityka konkurencji a ład rynkowy, Warszawa 2002.

50 W. Poczta, P. Siemański, Konkurencyjność..., dz. cyt., Poznań 2010, s. 21.

51 J. Wilkin, Ziemia rolnicza - dobro wielofunkcyjne, „Wieś i Rolnictwo”, 2014, t. 162, nr 1.
} 
prawnych, które mają zapobiec procesom dezagraryzacji ${ }^{52}$. Istnieje również w prawie krajowym szereg instrumentów prawnych, które wpływają na dostępność ziemi i obrót nieruchomościami rolnymi. Dość wspomnieć w tym miejscu o instytucji prawnej rolnika indywidualnego, który obecnie jest uprzywilejowanym nabywcą nieruchomości rolnych ${ }^{53}$.

W Polsce areał użytków rolnych ulega stałemu zmniejszeniu. W roku 2017 w porównaniu do roku 2010 zasoby te zmniejszyły się o ponad 240 tys. ha ${ }^{54}$. Pod względem powierzchni użytków rolnych Polska zajmuje trzecie miejsce wśród państw UE $^{55}$. W 2009 roku w całej UE odnotowano ponad $188 \mathrm{mln}$ ha użytków rolnych, w tym w Polsce 18,9 mln ha. Oznacza to konieczność przedsięwzięcia działań dla zachowania rolnego charakteru nieruchomości. Biorąc pod uwagę wyczerpalność tego zasobu niewątpliwie realizując zasadę zrównoważonego rozwoju ${ }^{56}$ należy już na wstępnym etapie analiz założyć konieczność zwiększenia mechanizmów prawnych, które zachęciłyby rolników do prowadzenia działalności rolniczej na posiadanych gruntach.

W danych statystycznych powierzchnia gospodarstw rolnych wyniosła 14056,64 tys. ha, a w zestawieniu z danymi z 2010 r. była mniejsza o 103484 ha $^{57}$. Ponad $74 \%$ gospodarstw rolnych stanowią gospodarstwa o powierzchni użytków rolnych do 10 ha, $15,1 \%$ stanowią gospodarstwa o powierzchni $10-20$ ha, a nieco mniej gospodarstw (10\%) posiada powierzchnię użytków rolnych powyżej 20 ha $^{58}$. Oznacza to, że większość pomocy dla rolników w Polsce trafia do gospodarstw małych. Toteż dobór instrumentów prawnych powinien być dostosowany do potencjalnego ich beneficjenta. Oczywiście nie można zapominać o gospodarstwach powyżej 20 ha użytku-

$52 \mathrm{O}$ mechanizmach tych szerzej w rozdziale 4 niniejszej publikacji. W tym miejscu wystarczy przywołać chociażby mechanizmy określone w rezolucji Parlamentu Europejskiego z dnia 27 kwietnia 2017 r. w sprawie aktualnego stanu koncentracji gruntów rolnych w UE: jak ułatwić rolnikom dostęp do gruntów?, http://www.europarl.europa.eu/sides/getDoc.do?pubRef=-//EP//TEXT+TA+P8-TA-2017$0197+0+$ DOC + XML + V0// PL\&language $=$ PL.

53 Por. szerzej K. Marciniuk, Prawne instrumenty ingerencji władzy publicznej w obrót nieruchomościami rolnymi jako środki kształtowania ustroju rolnego, Białystok 2019.

${ }^{54}$ Rocznik statystyczny rolnictwa 2018 r., s. 68.

55 Dane z 2017 r. na podstawie Rocznik statystyczny rolnictwa 2018 r.

56 Z. Bukowski, Koncepcja zrównoważonego rozwoju w działalności publicznej, [w:] Administracja publiczna - człowiek a ochrona środowiska. Zagadnienia społeczno-prawne, M. Górski, J. Bucińska, M. Niedziółka, R. Stec, D. Strus (red.), Warszawa 2011, s. 17-32; M.E. Szymańska, Zasada zrównoważonego rozwoju rolnictwa $w$ świetle uregulowań gatęzi prawa i polityki rolnej, „Studia Iuridica Lubliniensa”, 2016, t. 25, nr 1, s. 121-136; D. De Knecht, Zrównoważony rozwój, „Innowacje”, 2005 nr 25; W. Wołpiuk, Zasada zrównoważonego rozwoju. Zasada konstytucyjna czy zasada polityki społecznoekonomicznej w zakresie ochrony środowiska, „Zeszyty Naukowe Wyższej Szkoły Informatyki, Zarządzania i Administracji w Warszawie", 2003, z. 1, s. 7-18; S. Kozłowski, Strategia zrównoważonego rozwoju Unii Europejskiej i jej implikacje dla Polski, „Biuletyn Polskiego Klubu Ekologicznego”, 2004.

57 Dane z 2017 r. na podstawie Rocznik statystyczny rolnictwa 2018 r., s. 89.

58 Tamże, s. 89. 
jących 76957,9 tys. ha użytków rolnych ${ }^{59}$. Stanowią one blisko połowę dotowanych gruntów. Problemem wydaje się wyważenie wsparcia dla gospodarstw niskotowarowych, których jest znacznie więcej, a pomocą dla dużych gospodarstw, których co prawda jest mało, ale zajmują znaczny areał.

W całej UE jest 14482 tys. gospodarstw rolnych, w tym w Polsce 2391 tys. ${ }^{60}$. W porównaniu z rokiem 2007 wzrosła liczba gospodarstw grup obszarowych użytków rolnych o bardzo małej powierzchni, tj. do $1 \mathrm{ha}$, oraz tych średnich, tj. powyżej $10 \mathrm{ha}$. Większość grup obszarowych użytków rolnych $(53,3 \%$ ogólnej liczby gospodarstw rolnych) odnotowała spadek liczby gospodarstw rolnych.

Najnowsze badania wskazują, że zauważalne są zmiany w strukturze całego rolnictwa. W 2017 roku ponad 50\% użytków rolnych było skoncentrowanych w gospodarstwach o powierzchni co najmniej 20 ha. Takie skupienie ziemi nie jest równoznaczne z wyrównaniem warunków z pozostałymi krajami UE. Porównywalny wskaźnik w Czechach przewyższał 90\%, natomiast w Bułgarii $(83,8 \%)$, Danii $(82,2 \%)$, Estonii $(81,1 \%)$, Francji $(84,1 \%)$, Luksemburgu $(86,6 \%)$ i Wielkiej Brytanii $(87,1 \%)$ $80 \%$. Podobna koncentracja ziemi (powyżej 70\%) była skupiona w gospodarstwach o powierzchni co najmniej 50 ha w Niemczech i Hiszpanii61. Tempo zmian struktury obszarowej gospodarstw w Polsce, prowadzących do poprawy sytuacji, które można zmierzyć wzrostem przeciętnej powierzchni, jest oceniane za niedostateczne, szczególnie jeśli porównamy je z krajami leżącymi w środkowej i północnej części Europy ${ }^{62}$.

Prezentacja tylko niektórych danych dotyczących zasobów ziemi nakazuje poszukiwania kilku rodzajów mechanizmów prawnych, które będą w stanie poprawić konkurencyjność polskiego rolnictwa. Biorąc pod uwagę tylko zasoby ziemi, należy wypracować mechanizmy prawne, wspierające gospodarstwa małe. $Z$ uwagi na ich liczbę wsparcie to powinno być ukierunkowane na działania o charakterze inwestycyjnym. Niewątpliwie na sile powinny przybrać mechanizmy prawne, które pozwolą małym rolnikom na nabywanie nieruchomości rolnych w celu powiększania swoich areałów.

Analiza zasobów ziemi wskazała również, że o konkurencyjności rolnictwa decydują także gospodarstwa rolne o powierzchni powyżej 20 ha. W tym zakresie należy wskazać na role mechanizmów wspierających jakość produkcji rolnej oraz jej promocję. Nie bez znaczenia będą także mechanizmy prawne zmierzające do ochrony środowiska i klimatu. Tylko pobieżna analiza polityki zazieleniania podaje, że większość wymogów dotyczy gospodarstw rolnych o powierzchni powyżej 15 ha. To na

59 Rocznik statystyczny rolnictwa 2018 r., s. 73.

60 Dane za rok 2010, Rocznik statystyczny rolnictwa $2011 \mathrm{r}$.

61 F.J. Burgaz, The Spanish Agricultural Insurance Scheme: National Experiences and Recommendations Looking at the CAP Post 2013, Brussels 2010.

62 W. Poczta, Change in agriculture with particular focus on structural transformations, [w:] J. Wilkin, I. Nurzyńska, Rural Poland 2012 Rural Development Report, Warszawa 2012, s. 82. 
dużych gospodarstwach spoczywa obecnie obowiązek zachowania rolnego charakteru nieruchomości oraz jakość środowiska i klimatu.

Niewątpliwe znaczenie ma także wspieranie tych nieruchomości, które znajdują się w warunkach uniemożliwiających podstawową działalność rolniczą. Należy kontynuować wsparcie dla obszarów o niekorzystnych warunkach gospodarowania, czy obszarów Natura 2000 (te ostatnie zajmują ponad 20\% powierzchni Polski ${ }^{63}$ ). Problemem jest także zachowanie w dobrej kulturze rolnej nieruchomości o najwyższej klasyfikacji bonitacyjnej ${ }^{64}$. Dlatego też projektowane zmiany WPR po $2020 \mathrm{r}$. nastawione jeszcze bardziej na ochronę klimatu powinny odzwierciedlać konieczność takich rozwiązań prawnych, aby dążyć do ochrony nieruchomości o najlepszej jakości.

\subsubsection{Zasoby pracy}

Ważnym czynnikiem, mającym wpływ na konkurencyjność rolnictwa, jest dostęp do zasobów pracy. Rolnictwo, które wymaga znaczących nakładów siły roboczej jest analizowane przede wszystkim pod kątem wieku osób prowadzących działalność rolniczą. Istnieją instrumenty wspierające rolników, którzy po kilkudziesięciu latach pracy chcą zakończyć swoją działalność 65 . Przykładem takiej pomocy są renty strukturalne. Czynnik demograficzny ma tutaj dość duże znaczenie. Zasoby pracy są wspierane także przez dotowanie rolników, którzy zaczynają swoją działalność. Przede wszystkim znaczenia nabiera pomoc dla młodych rolników. Obecnie jest to kompleks powiązanych instrumentów, który daje znaczne przywileje rolnikom poniżej 40. roku życia66.

Statystycznie w rolnictwie, łowiectwie i leśnictwie w Polsce w 2018 roku pracowało ponad 2386,0 tys. osób. W porównaniu z rokiem 2010 liczba pracujących w rolnictwie wzrosła o 10 tys. osób ${ }^{67}$. Na stałym poziomie utrzymuje się liczba pracujących $\mathrm{w}$ gospodarstwach indywidualnych (2262,2 tys.). Zasoby pracy w analizowanym aspekcie konkurencyjności pozostają te same w ostatnim dziesięcioleciu. Problemem

63 Obszary te to 849 obszarów siedliskowych oraz 145 obszarów ptasich. A. Kozińska, Wdrażanie unijnego prawa ochrony środowiska w Polsce w latach 2001-2011, [w:] M. Rudnicki, A. Haładyj, K. Sobieraj, Dekada harmonizacji w prawie ochrony środowiska, Lublin 2011.

64 P. Skłodowski, A. Bielska, Właściwości i urodzajność gleb Polski-podstawa do ksztattowania relacji rolno-środowiskowych, „Woda, Środowisko, Obszary Wiejskie”, 2009, t. 9, z. 4.

65 R. Pastuszko, Kwalifikacja prawna umów zawieranych w zwiazku z przekazaniem gospodarstwa rolnego w celu uzyskania świadczeń emerytalno-rentowych, [w:] Obrót gospodarczy w prawie rolnym, B. Jeżyńska (red.), Lublin 2009.

66 B. Kiełbasa, J. Puchała, Innowacyjność młodych rolników i ich postawy wobec zmian na przyktadzie gospodarstw rolnych położonych $w$ regionie rozdrobnionego rolnictwa, „Roczniki Naukowe SERiA”, 2015, t. 17, nr 1, s. 107-111; H. Kałuża, A. Ginter, Innowacje w gospodarstwach rolniczych młodych rolników, „Prace Naukowe Uniwersytetu Ekonomicznego we Wrocławiu. Agrobiznes”, 2014, nr 361, s. 89-98.

67 Rocznik statystyczny rolnictwa 2018 r., s. 106. 
jest jednakże starzenie się rolników i dość nikły napływ nowej siły roboczej. Wyzwaniem nie tylko dla określenia granic prawnych, lecz także dla polityki rolnej staje się takie określenie pomocy dla młodych rolników, aby mogli oni się swobodnie rozwijać. To od ich udziału w rynku pracy w rolnictwie zależy w dużym stopniu poziom konkurencyjności rolnictwa.

W 2009 roku w UE aktywnych zawodowo w rolnictwie odnotowano ponad $11 \mathrm{mln}$, w tym w Polsce ponad 2 mln osób. Udział ludności aktywnej zawodowo w rolnictwie w 2009 roku w liczbie zatrudnionych ogółem wynosił 7,9\%. W zestawieniu z rokiem 2000 udział ten zmalał o 1,9 pkt. proc. Dane europejskie wskazują także na odpływ pracowników rolnych. Utrzymanie aktualnego stanu zatrudnienia może wydać się jeszcze trudniejsze z uwagi na rozwój innowacji w rolnictwie. Coraz częściej można zaobserwować, że proces zastępowania człowieka maszynami nie tylko usprawnia działalność, ale powoduje wzrost bezrobocia. WPR po 2020 r. nastawiona na wspieranie innowacji w rolnictwie powinna wziąć pod uwagę w większym stopniu ochronę osób pracujących w rolnictwie.

W sektorze polskiego rolnictwa poziom zatrudnienia jest bardzo wysoki, choć ostatnio można zaobserwować stagnację. Wynosił on około 15\% ogółu pracujących w gospodarce. Oznacza to, że aż co piąty rolnik pracujący w Unii Europejskiej jest Polakiem. W rezultacie produktywność pracy wynosi $30 \%$ średniej produktywności w rolnictwie UE i 1/4 średniej wydajności w polskiej gospodarce. Biorąc pod uwagę ten aspekt, gorsza sytuacja występuje tylko w Rumunii, Bułgarii i na Łotwie. Wsparcie na inwestycje w rolnictwie, przede wszystkim zaś modernizacja gospodarstw rolnych, powinny przynieść w tym zakresie poprawę. Zakup nowych urządzeń i maszyn, powiększając produktywność polskich rolników przyczyni się do wzrostu konkurencyjności rolnictwa. Dlatego też jedną z ważnych hipotez pracy uczyniono doskonalenie instrumentów prawnych w rolnictwie, które mają charakter inwestycyjny. Efekt ich działania nie tylko poprawia jakość pracy i produktów rolnych, ale zwiększa produktywność rolników.

W prowadzonych analizach zauważa się także niższą produktywność ziemi, która wykazywała o 34\% mniejszą wartość od średniej dla całej Unii w 2017 roku ${ }^{68}$. W tym zakresie nieodzowne stają się działania pomocowe zmierzające do zachowania rolnego charakteru terenów o najwyższej przydatności bonitacyjnej.

Problemem jest ulokowanie zasobów pracy w odpowiednich strukturach gospodarstw rolnych. Niemal 68\% ogółu osób wnoszących wkład pracy w gospodarstwo rolne znajduje się na gospodarstwach nieprzekraczających 7 ha. W gospodarstwach tych pracuje rolnik i jego rodzina. Praca własna stanowi główne źródło utrzymania rodzin rolniczych, ale także jest głównym wyznacznikiem konkurencyjności prowadzonych przez nich gospodarstw. Dlatego też dążąc do utrzymania optymalnej

68 Kujawsko-Pomorski Ośrodek Doradztwa Rolniczego, http://www.kpodr.pl [data dostępu 24 października 2018 r.]. 
wielkości gospodarstwa trzeba zwrócić uwagę na jego oddziaływanie na rynek pracy. Może się okazać, że gospodarstwa o powierzchni 10 ha będą za duże, aby rolnik sam na nich pracował, a za małe, aby mógł nająć siłę roboczą. Dlatego też obok wspierania mechanizmów powiększania gospodarstw rolnych, jak chociażby tych przewidzianych w rezolucji Parlamentu Europejskiego o ułatwianiu dostępu do ziemi rolnej, należy zadbać o wsparcie rynku pracy.

$\mathrm{W}$ analizowanym aspekcie znaczenia nabiera korzystanie $\mathrm{z}$ siły najemnej w rolnictwie. Dotyczy to przede wszystkim gospodarstw o powierzchni powyżej $30 \mathrm{ha}$. W Polsce jest obserwowany wzrost pracy najemnej w województwie: zachodniopomorskim, lubuskim, warmińsko-mazurskim, pomorskim oraz wielkopolskim. W tych regionach przeważają gospodarstwa duże i wielkopowierzchniowe ${ }^{69}$. Trudno obecnie znaleźć kompleksowe mechanizmy prawne, które wspierałyby rolników, chcących poprawić status swoich pracowników. Brakuje również zachęt do podnoszenia kwalifikacji pracowników najemnych. Trzeba także zwrócić uwagę, że duża część tych pracowników to pracownicy sezonowi związani z cyklem produkcyjnym w rolnictwie. Jednocześnie obserwowany wzrost kosztów pracy uniemożliwia rolnikom prowadzenie racjonalnej gospodarki finansowej swojej działalności. Do rangi symbolu urasta problem na rynku jabłek w Polsce ${ }^{70}$. Producentom opłaca się pozostawienie owoców w sadzie, niż ich zbiór i sprzedaż. Wsparcie mechanizmem oddziaływania na ceny skupu wydaje się koniecznością ingerencji w tę sferę rynku ${ }^{71}$.

Problemem rynku pracy w rolnictwie jest także dość niskie wykształcenie rolników. W zdecydowanej większości (2/3) posiadają oni wykształcenie najwyżej zasadnicze, a osoby mające wykształcenie podstawowe stanowią blisko połowę ogólnej liczby ludności rolniczej. Obserwowalna jest tutaj poprawa, czemu sprzyjają też prawne wymogi kwalifikacji rolniczych (chociażby w odniesieniu do normatywnej definicji rolnika indywidualnego ${ }^{72}$ ). Ma to znaczenie, gdyż WPR po $2020 \mathrm{r}$. zakłada w dużej części dotowanie innowacji w rolnictwie. Wymaga to specjalistycznej wiedzy i umiejętności obsługi skomplikowanych maszyn. Brak odpowiedniego przygotowania

69 W. Dzun, Duże gospodarstwa rolne przed i po wejściu do UE, [w:] Polska wieś i rolnictwo w Unii Europejskiej. Dylematy i kierunki przemian, Warszawa 2008; B. Karwat-Woźniak, Możliwości rozwojowe chlopskiego rolnictwa na przyktadzie gospodarstw wysokotowarowych. Raport nr 10, IERiGŻ, Warszawa 2005; B. Karwat-Woźniak, Gospodarstwa wysokotowarowe w rolnictwie chłopskim. Synteza wyników badań 2005-2009, Warszawa 2009, s. 27.

70 E. Makosz, Przyszłość polskich jabłek, „Biuletyn Informacyjny ARR”, 2015, nr 3.

71 S. Prutis, Dobór instrumentów prawnych slużacych wsparciu rozwoju obszarów wiejskich, „Studia Iuridica Agraria”, Białystok 2009, t. 7, s. 192-203; W. Ziętara, J. Sobierajewska, Konkurencyjność polskich gospodarstw sadowniczych, „Zagadnienia Ekonomiki Rolnej”, 2017, t. 350, nr 1, s. 101-116.

72 P. Blajer, Koncepcja rolnika indywidualnego w prawie polskim na tle porównawczym, Kraków 2009; K. Stefańska, Model indywidualnego gospodarstwa rolnego w świetle znowelizowanego kodeksu cywilnego, „Państwo i Prawo”, 1992, nr 3, s. 3; P. Blajer, Pojęcia gospodarstwa rodzinnego i rolnika indywidualnego w ustawie o kształtowaniu ustroju rolnego z dnia 5 sierpnia 2015 r., „Krakowski Przegląd Notarialny", 2016, nr 1. 
merytorycznego może okazać się znaczącą przeszkodą we wdrażaniu tego mechanizmu do polskiego rolnictwa.

Trudno zatem nie zgodzić się ze stwierdzeniem, że „znaczenie różnych czynników produkcji (zasobów organizacji) w miarę rozwoju gospodarczego zmienia się. Dawniej dominującą rolę odgrywała ziemia oraz ludzie (w sensie ilościowym). Początki kapitalizmu to kres wzrostu znaczenia kapitału, zarówno w sensie rzeczowym, jak i finansowym. We współczesnym rozwoju gospodarczym coraz większą rolę odgrywa wiedza i związana z nią technologia. Wiedza pozwala bowiem na lepsze wykorzystanie innych zasobów, a nawet można mówić o subsydiowaniu innych nakładów wiedzą"73.

Wykształcenie ludności rolniczej stanowi także barierę uniemożliwiającą albo też ograniczającą $\mathrm{w}$ dużym stopniu odchodzenie $\mathrm{z}$ rolnictwa, aby podejmować pracę poza tym sektorem. Niemożność przekwalifikowania się ze względu na brak umiejętności, z jednoczesną stagnacją sposobu prowadzenia działalności rolniczej może prowadzić w najlepszym stopniu do zahamowania konkurencyjności, a nie do jej wzrostu. Mechanizmy prawne, wspierające dokształcanie rolników, podnoszenie ich kwalifikacji, czy też przygotowanie do zmiany zawodu ${ }^{74}$, stanowią nadal małą część wydatków na finansowanie rolnictwa. Jego specjalizacja będzie wymuszała pozostanie jako rolników aktywnych zawodowo, tylko tych, którzy będą w stanie przyswoić sobie innowacyjne rozwiązania.

Niskie wykształcenie wpływa negatywnie na podejmowanie decyzji gospodarczych przez rolników ${ }^{75}$. Samo pozyskanie środków, opracowanie biznesplanów ${ }^{76}$, czy oszacowanie ryzyka staje się problemem w rozwoju rolnictwa ${ }^{77}$. Należy docenić działalność jednostek doradztwa rolniczego ${ }^{78}$. To zadania wsparcia merytorycznego rolników powinny stanowić jedno z nowych wyzwań dla polityki rolnej. Dobrze przygotowany merytorycznie rolnik do pozyskiwania pomocy na swoją działalność i znający podstawowe zagadnienia prowadzenia produkcji rolnej niewątpliwie wpłynie na poprawę konkurencyjności rolnictwa.

73 B. Klepacki, Wyksztatcenie jako czynnik różnicujacy zasoby, organizację i wyniki ekonomiczne gospodarstw rolniczych, Warszawa 2005.

74 P. Bórawski, Wykształcenie rolników i sytuacja ekonomiczna gospodarstw posiadajacych alternatywne dochody, ,Zeszyty Naukowe SGGW. Problemy Rolnictwa Światowego”, 2010, t. 10, nr 2, s. 5-11.

$75 \mathrm{~B}$. Kiełbasa, Education as a determinant of the implementation of innovation in agriculture in the light of empirical research, „Roczniki Naukowe SERiA”, t. 18, nr 1, s. 111-116.

76 D. Łobos-Kotowska, Planowanie inwestycji z udziałem środków EFRROW na obszarach wiejskich, „Studia Iuridica Agraria”, Białystok 2016, t. 14.

77 A. Ginter, H. Kałuża, S. Szarek, Wiedza czy mądrość? Czynniki ksztattujące przewagę konkurencyjna gospodarstw rolnych, „Wieś i Rolnictwo”, 2010, t. 149, nr 4, s. 120-129.

78 Por. Ustawa z dnia 22 października 2004 r. o jednostkach doradztwa rolniczego (Dz. U. z 2013 r. poz. 474); M.A. Król, Model doradztwa rolniczego w Polsce na tle rozwiązań przyjętych $w$ wybranych krajach członkowskich Unii Europejskiej, Warszawa 2013; J. Ryznar, Doradztwo rolnicze w zarysie, Wrocław 1995. 
Nowoczesne gospodarowanie na wsi jest rozumiane jako sztuka dopasowania się do zmieniających się warunków. Naukowe badania nad relacją powierzchni gospodarstwa rolnego i poziomem wykształcenia przeprowadził Bogdan Klepacki ${ }^{79}$. Rolnicy, posiadający wykształcenie podstawowe, zasadnicze lub średnie byli właścicielami podobnej wielkości gospodarstw, które w przeciągu sześciu lat powiększyli w przybliżonej skali ${ }^{80}$. Zupełnie odmienne wyniki dały gospodarstwa rolników z wykształceniem wyższym, którzy powiększyli powierzchnię swoich gospodarstw ponad dwukrotnie ${ }^{81}$. Oznacza to, że im większy poziom wykształcenia rolników, tym wykazywali oni większe zainteresowanie rozwojem prowadzonej działalności i byli skuteczniejsi w pozyskiwaniu środków produkcji, w tym przede wszystkim ziemi.

Rolnictwo stało się sektorem skomplikowanym ${ }^{82}$, który do sukcesu, tak jak i inne działy gospodarki, wymaga posiadania wiedzy i umiejętności, a także elastyczności oraz innowacyjności ${ }^{83}$. Niestety, wciąż wykształcenie polskich rolników jest czynnikiem hamującym rozwój rolnictwa i wpływającym negatywnie na konkurencyjność zasobów ludzkich ${ }^{84}$. Kwalifikacje rolnicze są także kryterium dostępu do nieruchomości rolnych. $\mathrm{Na}$ ich wagę wskazuje chociażby, szczegółowo analizowana w rozdziale czwartym rezolucja Parlamentu Europejskiego z dnia 27 kwietnia 2017 r. w sprawie aktualnego stanu koncentracji gruntów rolnych w UE: jak ułatwić rolnikom dostęp do gruntów? 85 .

\subsubsection{Inne wybrane zasoby, mające wpływ na konkurencyjność rolnictwa}

Omówione w dwóch poprzedzających podrozdziałach zasoby ziemi i pracy należy uznać za kluczowe dla funkcjonowania rolnictwa. One również stanowią najbardziej finansowany element w zakresie pomocy europejskiej. Istnieją jednakże mechanizmy prawne, które także oddziałują na inne zasoby w rolnictwie.

79 Por. M. Pietrzak, J. Paliszkiewicz, B. Klepacki, The application of the balanced scorecard (BSC) in thehigher education setting of a Polish university, „Online Journal of Applied Knowledge Management”, 2015, t. 3, nr 1, s. 151-164; B. Klepacki, E. Radochońska-Wasiewicz, Znaczenie programów wspierania konkurencyjności w opinii kierowników malych i średnich przedsiębiorstw, „Roczniki Naukowe Stowarzyszenia Ekonomistów Rolnictwa i Agrobiznesu", 2017, t. 19, nr 4, s. 117-123.

80 A. Nowak, T. Kijek, E. Wójcik, Wplyw wyksztatcenia rolników na produktywność pracy w towarowych gospodarstwach rolnych $w$ Polsce, ,Roczniki Naukowe Stowarzyszenia Ekonomistów Rolnictwa i Agrobiznesu", 2016, t. 18, nr 1.

81 B. Klepacki, Wyksztatcenie..., dz. cyt., 2005.

82 A. Harasim, A. Madej, A. Górnik, Innowacyjność różnych typów rolniczych gospodarstw w opinii rolników z makroregionu Mazowsza i Podlasia, „Roczniki Naukowe Stowarzyszenia Ekonomistów Rolnictwa i Agrobiznesu", 2017, t. 19, s. 70-76.

83 B. Klepacki, E. Radochońska-Wasiewicz, Sytuacja ekonomiczna matych i średnich przedsiębiorstw korzystających z programu wzrostu konkurencyjności, „Zeszyty Naukowe Szkoły Głównej Gospodarstwa Wiejskiego", 2017, nr 119, s. 5-21.

84 W. Poczta, P. Siemański. Konkurencyjność..., dz. cyt., Poznań 2010, s. 64.

85 Zob. http://www.europarl.europa.eu/sides/getDoc.do?pubRef=-//EP//TEXT+TA+P8-TA-20170197+0+DOC+ XML+V0// PL\&language=PL [data dostępu 30 marca 2019 r.]. 
Tradycyjnie pojmowana koncepcja ziemi, pracy i kapitału wpisuje się w prawo rynków. Sformułowane przez Jean-Baptiste Say'a na przełomie XVIII i XIX w. prawo rynku zakładało udział w nim także kapitału ${ }^{86}$. Aktualnie kapitał można określić zbiorczo jako środki trwałe i obrotowe. Stanowią one razem z ziemią i pracą podstawę zarówno faktycznego, jak i naukowego funkcjonowania zasad wolnego rynku. Są wynagrodzeniem za produkcję dla ich właściciela oraz wykonawcy. Wysokość tego wynagrodzenia jest zależna od poziomu konkurencji, który zdaniem Say'a w dużych miastach jest większy, niż na wsiach, gdzie wybór produktów jest ograniczony ${ }^{87}$.

Jednym z zasobów szczególnie finansowanym, chociażby przez modernizację gospodarstw rolnych, są środki trwałe ${ }^{88}$. Porównując lata 2010 (3716,0 mln zł) do 2017 roku (5270,4 mln zł) ${ }^{89}$ można zaobserwować znaczny wzrost nakładów na inwestycje w środki trwałe ${ }^{90}$. Dotyczą one nie tylko wspomnianych środków transportu, takich jak ciągniki ${ }^{91}$, ale także innych maszyn oraz urządzeń, czy inwestycji w budowle i budynki. Największy wzrost inwestycji można na tym polu analiz zaobserwować właśnie w modernizację̨2 $\mathrm{i}$ budowę budynków w gospodarstwach rolnych. W najbliższej perspektywie finansowej niewątpliwie należałoby dopracować te mechanizmy prawne, które pozwalają na szybsze przeprowadzanie tych inwestycji. Dotyczy to nie tylko instrumentów finansowych WPR ${ }^{93}$, ale także prawa budowlanego, czy planowania i zagospodarowania przestrzennego.

Powyższe dane pozwalają wysnuć jeszcze jedną obserwację. Inwestycje w rolnictwie powinny być skoordynowane na poziomie regulacji europejskich i krajowych. Pozostawienie rolników tylko z przyznaną pomocą finansową i narażenie ich na długoterminowe procedury uzyskiwania zezwoleń może spowodować zachwianie zauważalnego trendu wzrostowego. Nakłady na budownictwo w rolnictwie wyniosły $45 \%$ wszystkich pieniędzy inwestowanych w środki trwałe ${ }^{94}$.

86 J.B. Say, Traktat o ekonomii politycznej czyli prosty wyktad sposobu, w jaki się tworza, rozdzielaja i spożywaja bogactwa, Warszawa 1960.

87 J.B. Say, Le Traité d'économie politique, Paris 1803.

88 J. Zwolak, Ocena reprodukcji środków trwatych w rolnictwie polskim po 1990 roku, „Zagadnienia Ekonomiki Rolnej”, 2007, nr 1, s. 96-104; J. Pawlak, Efektywność środków trwatych mechanizacji w rolnictwie polskim w latach 1995-2013, „Problemy Inżynierii Rolniczej”, 2016, z. 24, s. 17-25.

89 Rocznik statystyczny rolnictwa 2018 r., s. 109.

90 W. Poczta, J. Średzińska, A. Standar, Sytuacja finansowa gospodarstw rolnych krajów UE wedtug potencjatu produkcyjnego, ,Journal of Agribusiness and Rural Development”, 2008, nr 10.

91 Rocznik statystyczny rolnictwa 2018 r., s. 114.

92 R. Pietrzykowski, L. Wicki, Regionalne zróżnicowanie wykorzystania środków z programów Wspólnej Polityki Rolnej na modernizację rolnictwa, „Roczniki Naukowe Rolnictwa”, Seria G, 2011, z. 4, s. 7-22.

93 W. Czubak, Wykorzystanie funduszy Unii Europejskiej wspierajacych inwestycje w gospodarstwach rolnych, „Journal of Agribusiness and Rural Development”, 2012, t. 25, nr 3, s. 57-67.

94 Rocznik statystyczny rolnictwa 2018 r., s. 110. 
Ważnym zasobem wpływającym na konkurencyjność rolnictwa są także środki obrotowe ${ }^{95}$. Można chociażby zaliczyć do nich produkcję nawozów ${ }^{96}$, środki ochrony roślin ${ }^{97}$, materiał siewny. Tylko te przykładowe elementy - ich dostępność oraz prawna możliwość stosowania - stanowią o możliwości podniesienia poziomu konkurencyjności rolnictwa. Zakładając realizację przedstawionych celów WPR po $2020 \mathrm{r}$. należy wskazać, że większy nacisk zostanie położony nie tylko na ochronę środowiska i klimatu ${ }^{98}$, ale także na innowacyjność 99 . Otwiera to drogę do wykorzystywania w produkcji rolnej nowoczesnych środków i materiałów siewnych, które nie tylko zapewnią bezpieczeństwo konsumenta, ale także podwyższą dochód rolnika.

W tym ostatnim aspekcie niezwykle ważnym zasobem w rolnictwie są pieniądze ${ }^{100}$. Poza środkami pochodzącymi z budżetu europejskiego rolnicy dysponują także środkami własnymi. Wartość produkcji rolnej wyraźnie wzrasta w porównaniu roku 2010 (84 484,2mln zł) do 2017 roku (115 611,7 mln zł) ${ }^{101}$. Rośnie przy tym dynamika nominalnych dochodów $\mathrm{w}$ gospodarstwach indywidualnych ${ }^{102}$. W przywołanym okre-

95 A. Tarnowska, Środki obrotowe a wielkość produkcji wybranych ziemiopłodów $w$ dolnoślaskich gospodarstwach rolnych na tle kraju w latach 1999-2014, „Optimum. Studia Ekonomiczne”, 2016, t. 82 , nr 4, s. $167-184$.

96 F. Czyzyk, Ocena zużycia nawozów mineralnych $w$ gospodarstwach rolnych $w$ aspekcie ochrony środowiska, „Problemy Inżynierii Rolniczej”, 2011, nr 3.

97 Krajowy plan działania na rzecz ograniczania ryzyka zwiąanego ze stosowaniem środków ochrony roślin na lata 2013-2017, Ministerstwo Rolnictwa i Rozwoju Wsi, Warszawa 2012; S. Stobiecki, System gromadzenia danych o sprzedaży i zużyciu środków ochrony roślin w Polsce na tle wymogów Unii Europejskiej. Stan obecny i perspektywy, „Postęp w Ochronie Roślin”, 2006, t. 1, nr 46.

98 W. Józwiak, Zagrożenia przyrodniczo-klimatyczne dla gospodarstw rolnych osób fizycznych na tle ich sytuacji dochodowej, „Zagadnienia Ekonomiki Rolnej”, 2016, t. 348, z. 3, s. 24-40; A. Kagan, Procesy dostosowawcze wielkotowarowych gospodarstw rolnych w kontekście średniookresowego przegląu WPR oraz polityki klimatyczno-środowiskowej UE, Instytut Ekonomiki Rolnictwa i Gospodarki Żywnościowej - Państwowy Instytut Badawczy, Warszawa, 2018.

99 W polskim PROW 2014-2020 można przeczytać, że: „Innowacyjność jest ważnym czynnikiem poprawy produktywności, wzrostu i konkurencyjności sektora rolnego oraz doskonalenia jakości produktów, a przez to sposobem na poprawę dochodów rolników. Jednocześnie, rozwiązania innowacyjne mogą sprzyjać dostosowaniu działalności rolniczej do potrzeb środowiska. Ze względu na niski poziom innowacyjności sektora rolno-spożywczego, istnieje potrzeba zwiększenia nakładów na działalność badawczo-rozwojową (w tym dotyczących rozwiązań przyjaznych dla środowiska i klimatu), liczby wdrożonych rozwiązań innowacyjnych oraz transfer nowoczesnych i już znanych rozwiązań. Dla zwiększenia innowacyjności konieczne jest stworzenie warunków sprzyjających jej rozwojowi. Podniesienie świadomości (w tym ekologicznej) i kwalifikacji rolników oraz większa dostępność informacji o istniejących rozwiązaniach pociąga za sobą wzrost popytu”, s. 50.

100 W. Poczta, J. Średzińska, A. Mrówczyńska-Kamińska, Determinanty dochodów gospodarstw rolnych Unii Europejskiej wedlug typów rolniczych, „Zeszyty Naukowe SGGW. Ekonomika i Organizacja Gospodarki Żywnościowej”, 2009, nr 76, s. 17-30.

101 Rocznik statystyczny rolnictwa 2018 r., s. 126.

102 P. Bórawski, A. Lewczyk, Zróżnicowanie wyników ekonomicznych indywidualnych gospodarstw rolnych w zależności od potencjału konkurencyjnego, a zwłaszcza ziemi, „Roczniki Naukowe SERiA”, 2008, t. 10, z. 3. 
sie siedmiu lat był to wzrost o 41,5\% ${ }^{103}$. Dane te wskazują, że globalna sytuacja rolników ulega poprawie. Trzeba jednakże dokonać analiz poszczególnych mechanizmów prawnych, aby odpowiedzieć na pytanie: czy nie opóźniają one działań wzrostowych, czy też nie można w nich dokonać pewnych ulepszeń?

W pracy będą analizowane dla potrzeby ilustracji efektów pewnych instrumentów prawnych inne dane ekonomiczne. $Z$ uwagi jednakże na prawny charakter pracy przedstawiona analiza poszczególnych zasobów ma jedynie wskazać na najbardziej pożądane kierunki zmian.

\subsection{Rodzaje konkurencyjności}

W nauce można wyróżnić kilka rodzajów konkurencyjności. W zależności od wyboru danego poglądu i klasyfikacji można zacząć determinować wybory prawne w zakresie wsparcia poszczególnych sektorów, nastawiając się na skalę makro- czy mikroekonomiczną ${ }^{104}$, kładąc większy nacisk na zwiększenie konkurencyjności $\mathrm{w}$ aspekcie międzynarodowym. Poniższy krótki przegląd doskonale pokazuje jak wybór konkretnego podejścia do konkurencyjności determinuje rozwiązania prawne.

\subsubsection{Konkurencyjność sektorowa}

Jedna $\mathrm{z}$ podstawowych teorii konkurencyjności sektorowej (przemysłowej) wskazuje, że sektor to grupa podmiotów gospodarczych (przedsiębiorstw), które wytwarzają zbliżone produkty, wykorzystując podobne techniki wytwarzania i konkurujących ze sobą o zaspokojenie konkretnych potrzeb konsumentów ${ }^{105}$. Zgodnie z powyższą teorią konkurencja $\mathrm{w}$ danym sektorze zależy od pięciu zasadniczych sił, a mianowicie:

1) groźby pojawienia się na rynku nowych produktów,

2) groźby wejścia na rynek dóbr substytucyjnych,

3) siły przetargowej firm dostarczających produkty,

4) siły przetargowej konsumentów,

5) rywalizacji pomiędzy funkcjonującymi na rynku konkurentami ${ }^{106}$.

Rolnictwo jest niewątpliwie sektorem, na którym działa wszystkie pięć sił Portera. Znajdują one również odzwierciedlenie w celach WPR, wskazujących na pozycję

103 Rocznik statystyczny rolnictwa 2018 r., s. 192.

104 A. Czyżewski, A. Henisz, Makroekonomiczne determinanty przemian strukturalnych $w$ rolnictwie, [w:] Nowoczesne zarzadzanie przedsiębiorstwem, J. Stankiewicz (red.), Zielona Góra 2002.

105 M.E. Porter, The Competitive..., dz. cyt., s. 207.

106 W. Poczta, P. Siemański. Konkurencyjność..., dz. cyt., Poznań 2010, s. 22. 
konsumentów i w dbaniu o rolnictwo jako osobny sektor gospodarki. Określenie intensywności poszczególnych sił wpływa na wybór pozycji konkurencyjnej niwelującej oddziaływanie powyższych sił. Takie postępowanie pozwala dokonać wyboru jednej z dwóch głównych strategii konkurencji: niskich kosztów wytwarzania, co umożliwia osiąganie wysokich zysków w odniesieniu do konkurentów czy zróżnicowania produkcji, co umożliwia oferowanie dóbr o wyższej jakości. Dywersyfikacja produkcji rolnej jest jednym ze współczesnych wyznaczników polityki zazieleniania.

Opisywana teoria Portera za podstawę konkurowania przedsiębiorstw uznaje zdolność reagowania na zagrożenia oraz szanse wypływające $\mathrm{z}$ otoczenia. W tym zakresie osiągnięcie korzyści konkurencyjnych stanowi podstawę uzyskania ponadprzeciętnych długookresowych wyników i pozostaje w trwałym związku ze zdolnością wykorzystywania przewag konkurencyjnych ${ }^{107}$. Przewagi te stanowią o wzroście konkurencyjności nie konkretnego rolnika, ale także całego sektora ${ }^{108}$.

Od 1 maja 2004 r., czyli od akcesji Polski do UE, rolnictwo polskie musi sprostać i wygrać rywalizację z nowymi rolnikami z UE, a także musi być przygotowane na to, że w każdej chwili na rynku może pojawić się nowy produkt lub dobro substytucyjne. Produkt ten może pochodzić nie tylko z państw trzecich, takich jak Kanada, czy Japonia (w wyniku podpisanych umów handlowych), ale także z innych państw UE. Konkurencyjność polskiego rolnictwa jest również pod wpływem oddziaływania nowych konsumentów z obszaru UE, których siła przetargowa jest znacznie większa aniżeli dostawców. Rolnictwo zarówno polskie, jak innych państw członkowskich nie posiada gospodarstw rolnych o tak dużej sile rynkowej, aby mogły one samodzielnie działać na rynku, ,ich potencjał jest zbyt mały, aby były w stanie prowadzić samodzielną politykę produkcyjną i eksportową. Ich zdolności konkurencyjne na rynkach międzynarodowych w decydującym stopniu zależą od polityki państwa [...] rolnictwo i jego zdolności konkurencyjne są produktem unijnej polityki rolnej, która przewiduje głęboko sięgającą protekcję"109. Konkurencyjność sektorową rolnictwa kształtują instrumenty polityki ekonomicznej, a przede wszystkim WPR, które mogą wpływać bezpośrednio lub pośrednio na możliwości konkurencyjne rolnictwa ${ }^{110}$.

Konkurencyjność sektorowa pozwala także na wspieranie w ramach rolnictwa poszczególnych gałęzi produkcji rolnej. Obserwowalne jest to przede wszystkim na jednolitym wspólnym rynku wina, czy oliwek. Mechanizmy te ulegają w każdym nowym okresie programowania modyfikacjom legislacyjnym.

107 Tamże, s. 22.

108 T. Dołęgowski, Konkurencyjność a procesy integracyjne w Europie, Warszawa 2000.

109 A. Woś, Makroekonomiczne uwarunkowania rozwoju sektora żywnościowego, [w:] Analiza produkcyjno-ekonomicznej sytuacji rolnictwa i gospodarki żywnościowej w 2002 roku, Warszawa 2003.

110 W. Poczta, P. Siemański. Konkurencyjność..., dz. cyt., Poznań 2010, s. 23. 


\subsubsection{Konkurencyjność regionalna}

Jednym z głównych założeń WPR jest niwelowanie różnic rozwojowych rolnictwa w poszczególnych państwach członkowskich. W tym zakresie jest wspierany rozwój regionalny. Określone instrumenty prawne celowane są na poszczególne działania, które ze względu na odpowiednie ukształtowanie terenu, czy walory przyrodnicze przyniesie najlepsze efekty ekonomiczne.

Konkurencyjność regionalna jest określana jako umiejętność zapewnienia trwałego oraz długookresowego wzrostu, który jest pojmowany jako stan gospodarki określonego regionu, umożliwiający poprawę poziomu życia ludności tego regionu, wzrost dochodów, poprawę zatrudnienia, a także zachowanie przywództwa technologicznego ${ }^{111}$. Można zaobserwować, że regiony winnic we Francji, oliwy z oliwek w Hiszpanii112, czy serów we Włoszech ${ }^{113}$ skutecznie wykorzystują przewagę regionalną. W tym zakresie tworzone są instrumenty prawne, jak chociażby ochrona geograficznych nazw pochodzenia ${ }^{114}$. Chroni to produkty rolne, pochodzące $\mathrm{z}$ danych regionów, przed nieuprawnioną konkurencją.

Definicja konkurencyjności międzynarodowej ograniczona do poziomu regionu, za konkurencyjność regionu uznaje umiejętność podmiotów gospodarczych działających w danym regionie do uzyskiwania ze społecznego podziału pracy wyższych korzyści w porównaniu z konkurentami funkcjonującymi w innych regionach, żeby powiększyć rozmiar dochodu oraz jeszcze $\mathrm{w}$ większym stopniu zaspokajać rozmaite potrzeby konsumentów, doprowadzając do szeroko rozumianego rozwoju społecznogospodarczego danego regionu ${ }^{115}$.

W nauce wskazuje się, iż regiony ${ }^{116}$ są konkurencyjne, „gdy dzięki długofalowej, zintegrowanej, kompleksowej polityce ich rozwoju charakteryzują się ekonomicznymi,

111 Na podstawie: The world competitiveness report, www.imd.org.

112 A.M. Gutiérez, Ochrona rodzinnego gospodarstwa rolnego w prawie hiszpańskim, [w:] Prawne mechanizmy wspierania i ochrony rolnictwa rodzinnego w Polsce i innych państwach Unii Europejskiej, P. Litwiniuk (red.), Warszawa 2015, s. 293-307; T.V. Ruano, Repercusión del Avance Tecnológico en la Ampliación del Comercio de Productos Agroalimentarios en un Mercado Globalizado, „Przegląd Prawa Rolnego", 2017, t. 21, nr 2, s. 13-30.

113 F. Adornato, Ochrona rodzinnego gospodarstwa rolnego we Włoszech, [w:] Prawne mechanizmy wspierania i ochrony rolnictwa rodzinnego w Polsce i innych państwach Unii Europejskiej, P. Litwiniuk (red.), Warszawa 2015, s. 283-291; F. Adinolfi, U. Altomare, L. Boanini, M. Di Domenico, F. Capitanio, G. Casadio, M. Guido, F. Trezza, Sviluppo rurale 2014-2020: Studio per l'attuazione in Italia dello strumento di stabilizzazione del reddito delle imprese agricole, Roma 2015.

114 A. Wróbel, Modele ochrony oznaczeń geograficznych w Unii Europejskiej i Stanach Zjednoczonych - problematyka prawna, Łódź, 2015; R. Skubisz, P. Gała, E. Całka, Prawo własności przemysłowej, Warszawa 2017; C. Tallia, L. Fornabaio, The new decrees regarding mandatory origin labeling in France and Italy: some guidelines, „Dritto Agrario”, 2017, z. 1, s. 109-123; A. Kapała, Legal Determinants of Quality Policy for Agricultural Products and Foodstuffs, „Studia Iuridica Lublinensia”, 2017, t. 26, s. 489.

115 W. Poczta, P. Siemański. Konkurencyjność..., dz. cyt., Poznań 2010, s. 24.

116 W. Sługocki, Rola funduszy Unii Europejskiej w budowaniu konkurencyjności polskich regionów, „Marketing i Rynek”, 2016, z. 10, s. 517-533. 
społecznymi i technicznymi warunkami umożliwiającymi, a zarazem wymuszającymi, wysoką jakość produkcji, wysoką efektywność firm, wdrażanie nowych produktów i nowych zasobooszczędnych technologii, skracanie czasu wytwarzania produktu finalnego, wzrost wydajności pracy oraz szybką rynkową realizację produktów"117. Podejście to pozwala uznać, iż każdy region odpowiednio do posiadanych zasobów dysponuje konkretnymi możliwościami rozwoju konkurencyjnego ${ }^{118}$. Należy podkreślić, że regiony, które do tej pory nie były uważane za konkurencyjne mogą stać się takimi w przyszłości, jednocześnie zasada ta działa w drugą stronę, a więc regiony konkurencyjne dziś w przyszłości mogą stracić tę właściwość119. Dlatego też konkurencyjność regionalna powinna być ciągle wspierana i doskonalona.

\subsubsection{Konkurencyjność mikroekonomiczna}

Ważnym elementem oceny poziomu konkurencyjności i efektywności wydatkowanych środków jest ocena konkurencyjności mikroekonomicznej ${ }^{120}$. Charakteryzuje ona umiejętność danego podmiotu gospodarczego do stałego tworzenia tendencji rozwojowej, a także wzrostu mikroproduktywności i efektywnego rozwijania rynków zbytu, podczas gdy konkurenci oferują nowe, lepsze, a przede wszystkim tańsze produkty ${ }^{121}$. Ocena funkcjonowania działalności rolniczej w skali mikro pozwala dokonać wyboru właściwych instrumentów prawnych w celu realizacji celów WPR. Rolnik po wykorzystaniu środków pomocowych przedstawia jego rozliczenie, gdzie wskazuje nie tylko poprawę dochodowości, ale także inne wskaźniki, jak chociażby GVA ${ }^{122}$. To wzrost wartości dodanej staje się wyznacznikiem oceny skuteczności rozwiązań prawnych. Powstaje pytanie: czy tak silny związek czynników ekonomicznych z prawem w dhuższej perspektywie nie będzie szkodził rozwiązaniom prawnym?

$\mathrm{Na}$ konkurencyjność mikroekonomiczną wpływają czynniki różnego rodzaju. Pierwszym rodzajem czynników są to czynniki zewnętrzne, które są niezależne od

117 K. Kuciński, Konkurencyjność jako zagadnienie regionalne, Warszawa 1998.

118 M. Grębowiec, Produkty regionalne i tradycyjne jako element budowania konkurencyjnej oferty produktów żywnościowych w Polsce i innych krajach Europy, „Zeszyty Naukowe Szkoły Głównej Gospodarstwa Wiejskiego w Warszawie - Problemy Rolnictwa Światowego", 2017, t. 17, z. 2, s. 65-80.

119 W. Poczta, P. Siemański, Konkurencyjność..., dz. cyt., Poznań 2010, s. 24

120 A. Niewiadomska, Konkurencyjność w rolnictwie - wybrane aspekty, [w:] Wplyw funduszy strukturalnych na poprawę konkurencyjności polskiego rolnictwa, A.Z. Nowak (red.), Warszawa, 2013, s. 81.

121 H.G. Adamkiewicz, Wewnętrzne i zewnętrzne uwarunkowania konkurencyjności przedsiębiorstw, [w:] Konkurencyjność gospodarki Polski w warunkach integracji z Uniq Europejska i globalizacji, J. Staszewski (red.), Warszawa 2004.

122 GVA - ang. gross value added, czyli wzrost wartości dodanej brutto gospodarstwa rolnego, porównując rok bazowy (moment ubiegania się o dofinansowanie) do 5 roku trwania operacji. GVA oblicza się według wzoru: GVA = Wartość produkcji w gospodarstwie rolnym (przychody) - koszty produkcji w gospodarstwie rolnym (koszty uzyskania przychodu), przy czym warto wiedzieć, że przyjmuje się stałe ceny płodów rolnych, jak i koszty środków produkcji dla roku bazowego, jak i całego okresu 5 lat działania programu. GVA występuje obok określania wielkości gospodarstwa za pomocą jednostek ESU. 
podmiotu gospodarczego, a sam podmiot nie ma właściwie na nie wpływu. Do nich można zaliczyć zjawiska chorobowe wśród zwierząt, susze, powodzie, wichury ${ }^{123}$. W tym zakresie regulacje WPR przewidują odpowiednie narzędzia pomocowe. Drugim rodzajem czynników, tzw. wewnętrznych, podmiot może kierować, ustalając stosowne ich kombinacje w czasie procesu produkcyjnego. Do tych czynników można zaliczyć: formę własności podmiotu gospodarczego, system organizacji oraz zarządzania, poziom kwalifikacji pracowników ${ }^{124}$, właściwość decyzji, które zostają podjęte w odniesieniu do procesu produkcyjnego, czy relacje zachodzące między podmiotem gospodarczym a rynkiem. Wiele wśród tych decyzji zależy od samego rolnika. Dlatego też ważnym aspektem przyznawanej pomocy jest etap wnioskowania, gdzie wymaga się m.in. przedstawienia założeń biznesowych prowadzonej działalności.

W najnowszych badaniach naukowych konkurencyjność mikroekonomiczna zależy w głównej mierze od kosztów produkcji oraz cen, a także od jakości towarów i zachodzących procesów ekonomicznych. Regulacje WPR w dużej mierze dotykają instrumentów cenowych, ustalając odpowiedni poziom zarówno na rynku wewnętrznym UE ${ }^{125}$, jak i w handlu z państwami trzecimi. Obecny okres programowania, a także perspektywa realizacji WPR po $2020 \mathrm{r}$. zakładają zwiększenie roli mechanizmów prawnych oddziałujących na jakość produkcji rolnej. W rezultacie konkurencyjność w tym ujęciu sprowadza się do sytuacji finansowej podmiotu gospodarczego, do wyniku finansowego tego podmiotu ${ }^{126}$. Wynik ten, jak podkreślano, zależy zarówno od czynników zewnętrznych, jak i wewnętrznych. Prowadzi to do trudności w jednoznacznej ocenie, które z tych czynników i w jakim stopniu przyczyniły się do określonego poziomu konkurencyjności danego podmiotu.

W uznanej literaturze można odnaleźć ponadto pogląd, iż kryterium oceny konkurencyjności mikroekonomicznej stanowi realizowany długookresowy zysk podmiotu, a także znaczący poziom parametrów eksploatacyjnych oraz własności użytkowych dóbr dostarczanych na dany rynek ${ }^{127}$. Efektywność staje się w tym zakresie kluczem do oceny nie tylko poszczególnych przedsięwzięć biznesowych, lecz także rozwiązań prawnych. Umiejętność gospodarstwa do generowania zysku jest wskaźnikiem dobrego wykorzystania posiadanego kapitału zarówno ludzkiego, jak i rzeczowego - optymalnego jak wskazuje art. 39 TFUE wykorzystania zasobów. Tymczasem

123 Różne formy pomocy klęskowej dla rolników i rybaków, „Biuletyn Informacyjny MRiRW”, 2018, $\mathrm{nr} 9$.

124 P. Blajer, Wymóg kwalifikacji rolniczych w obrocie nieruchomościami. Studium prawnoporównawcze, „Przegląd Prawa Rolnego”, 2008, nr 2, s. 52 i nast.

125 Por. wyrok TS z 10 stycznia 1985 r. w sprawie 229/83 Association des Centres distributeurs Éduard Leclers i inni przeciwko SARL „Au blé” i inni, Zb. Orz. 1985, s. 1.

126 T. Gołębiewski, TRANS'99: Wspólna Europa. Międzynarodowa konkurencyjność polskich przedsiębiorstw, Warszawa 1999.

127 J. Biernat, Polska gospodarka w świetle niektórych kryteriów oceny konkurencyjności gospodarki, [w:] Konkurencyjność gospodarki Polski w warunkach integracji z Unia Europejska i globalizacji, J. Staszewski (red.), Warszawa 2004. 
straty oznaczają konieczność przekształcenia sposobu działania prowadzonego do tej pory ${ }^{128}$. Stąd nie można nie zgodzić się ze stwierdzeniem, iż aby stać się konkurencyjnym na danym rynku, działalność musi charakteryzować się efektywnym sposobem prowadzenia ${ }^{129}$. Konkurencyjność podmiotu gospodarczego w rolnictwie można zatem mierzyć, badając rynkową konkurencyjność rolnictwa, a także analizując umiejętność podmiotów gospodarczych do generowania dochodów (konkurencyjność wytwarzania) ${ }^{130}$.

\subsection{Konkurencyjność jako kategoria prawna w regulacjach rolnych}

Konkurencyjność stała się ważnym wyznacznikiem również dla realizowania WPR. Przywołany już fragment art. 39 TFUE wyraźnie wskazuje, że wzrost ekonomiczny poprzez optymalne wykorzystanie zasobów, a zwłaszcza siły roboczej staje się jednym z głównych celów WPR. Problemem tylko pozostaje dopasowanie odpowiednich instrumentów prawnych do realizacji tak zakreślonego celu. W europejskiej nauce prawa rolnego, wskazuje się, że określanie konkurencyjności stało się częścią regulacji umownie istniejących kodyfikacji rolnych ${ }^{131}$.

Konkurencyjność i konkurencja nie zostały w wystarczający sposób zdefiniowane w aktach prawnych. Odnalezienie znaczącej definicji legalnej tych pojęć jest niemożliwe. Analizowane regulacje rolne, ale także inne akty prawne, jak chociażby te dotyczące ochrony konkurencji i konsumentów, nie posługują się definicjami legalnymi konkurencyjności. Oznacza to, że zgodnie z wykładnią językową należy ją thumaczyć poprzez pryzmat znaczeń słownikowych. Tu powstaje problem. „Słownik języka polskiego" nie notuje tego pojęcia. Można odnaleźć tylko znaczenie słowa konkurencja. Sama ta kwerenda pokazuje, że do oceny mechanizmów prawnych, w jakim stopniu realizują one cele WPR w zakresie konkurencyjności, trudno będzie dobrać jednoznaczne mechanizmy.

Dlatego też poczynione powyżej wywody dotyczące konkurencyjności w nauce przybierają na znaczeniu. To zaprezentowane podejścia naukowe stają się punktem odniesienia dla oceny rozwiązań prawnych. Aby móc ocenić, czy zrealizowano cel wzrostu konkurencyjności należy wiedzieć, czym jest konkurencyjność.

Konkurencyjność stała się elementem polskich aktów prawnych dotyczących rolnictwa. W Programie Rozwoju Obszarów Wiejskich 2014-2020 (PROW 2014-2020) wskazano, że „najistotniejszą kwestią dla sektora rolnego, realizowaną w Programie

128 T. Przybyciński, Polityka konkurencji a ład rynkowy, Warszawa 2002.

129 W. Poczta, P. Siemański, Konkurencyjność..., dz. cyt., Poznań 2010, s. 25.

130 A. Woś, Konkurencyjność potencjalna polskiego rolnictwa, Warszawa 2001.

131 F. Albisini, Europejskie kodeksy rolnictwa i ponowne odkrycie rolnictwa jako działalności produkcyjnej, [w:] Kwestia agrarna. Zagadnienia prawne i ekonomiczne, P. Litwiniuk (red.), Warszawa 2016, s. 352. 
będzie poprawa jego konkurencyjności. Potrzeba będzie realizowana poprzez wsparcie inwestycyjne takich gospodarstw rolnych, które na skutek interwencji uzyskają trwałą rentowność"132. Należy podkreślić, że konkurencyjność jest uznawana przez WPR oraz krajowe regulacje za najważniejszą i najistotniejszą cechę sektora rolnego. Wszystkie analizowane mechanizmy prawne są podporządkowane wzrostowi konkurencyjności, a sama konkurencyjność stała się determinantą rozwojową rolnictwa ${ }^{133}$. Pogląd ten ulega jednak ewolucji w dokumentach dotyczących przyszłej WPR po $2020 \mathrm{r}$.

W regulacjach europejskich nie tylko konkurencyjność została wyraźnie określona, dopracowano także reguły konkurencji. Określono je w Traktacie o funkcjonowaniu Unii Europejskiej, a później doprecyzowano w szeregu rozporządzeń europejskich ${ }^{134}$. Szczególnie ważny wydaje się tutaj art. 40 ust. 1 TFUE. Wskazano w nim, że zależnie od produktów, organizacja rynku rolnego przybiera także wspólne reguły konkurencji. Zasady te dotyczą relacji na rynku wewnątrz Unii (jak: interwencja rynkowa, dopłaty do prywatnego przechowania, system cen, specjalne wsparcie dla poszczególnych produktów rolnych ${ }^{135}$ ), czy też handlu z państwami trzecimi ${ }^{136}$ (nomenklatura scalona, wspólny taryfikator celny, certyfikaty importowe i eksportowe, kwoty przywozowe ${ }^{137}$ ). To realizacja głównego założenia - wzrostu konkurencyjność rolnictwa doprowadziła to wypracowania i ewolucji tych mechanizmów prawnych.

Ewolucja ta już jest obserwowalna w debacie nad przyszłą WPR po $2020 \mathrm{r}$. W Komunikacie Komisji do Parlamentu Europejskiego, Rady, Europejskiego Komitetu

132 PROW 2014-2020, s. 51.

133 Szerzej na ten temat por. A. Niewiadomska, Konkurencyjność jako determinanta prawna europejskiej polityki rolnej, „Studia Iuridica”, 2017, t. 72, s. 267-278.

134 Rozporządzenie Parlamentu Europejskiego i Rady (UE) nr 1308/2013 z dnia 17 grudnia 2013 r. ustanawiające wspólną organizację rynków produktów rolnych oraz uchylające rozporządzenia Rady (EWG) nr 922/72, (EWG) nr 234/79, (WE) nr 1037/2001 i (WE) nr 1234/2007 (Dz. Urz. UE L z 2013 r. nr 347, s. 671 ze zm.); wcześniej Rozporządzenie Rady (WE) nr 1234/2007 z 22 października 2007 r. ustanawiające wspólną organizację rynków rolnych oraz przepisy szczegółowe dotyczące niektórych produktów rolnych (,rozporządzenie o jednolitej wspólnej organizacji rynku”), Dz. Urz. UE L 299 z 16 listopada 2007 r., s. 1-149 ze zm.

135 Np. rozporządzenie wykonawcze Komisji (UE) nr 428/2014 z dnia 25 kwietnia 2014 r. przyjmujące nadzwyczajne środki wspierania rynku wieprzowiny na Litwie i zmieniające rozporządzenie wykonawcze (UE) nr 324/2014 przyjmujące nadzwyczajne środki wspierania rynku wieprzowiny w Polsce (Dz. Urz. UE L z 2014 r. Nr 125 s. 64); rozporządzenie wykonawcze Komisji (UE) nr 324/2014 z dnia 28 marca 2014 r. przyjmujące nadzwyczajne środki wspierania rynku wieprzowiny w Polsce (Dz. Urz. UE L z 2014 r. Nr 95 s. 24); rozporządzenie wykonawcze Komisji (UE) 2016/760 z dnia 13 maja 2016 r. w sprawie nadzwyczajnych środków wsparcia dla sektorów jaj i mięsa drobiowego we Włoszech (Dz. Urz. UE L z 2016 r. Nr 126, s. 63); I. Lipińska, Nadzwyczajne środki wsparcia jako prawna ochrona unijnego rynku rolnego, „Przegląd Prawa Rolnego”, 2017, t. 20, nr 1, s. 81-96.

136 P. Czechowski, A. Niewiadomski, Europejskie rynki rolne, [w:] Prawo rolne, P. Czechowski (red.), Warszawa 2015, s. 390-405.

137 E. Tomkiewicz, Limitowanie produkcji w ustawodawstwie rolnym Wspólnoty Europejskiej, Warszawa 2000. 
Ekonomiczno-Społecznego i Komitetu Regionów „Przyszłość rolnictwa i produkcji żywności" z dnia 29 listopada 2017 r. ${ }^{138}$ określa się ramy polityczne dla nowej legislacji rolnej. W każdym podejmowanym działaniu celem przyszłych regulacji ma być nie tylko pogłębianie zasad ochrony środowiska, zmiany klimatu, bezpośrednie wsparcie, ale także ciągłe zwiększanie konkurencyjności. Konkurencyjność staje się już może nie najważniejszym czynnikiem rozwojowym, ale jednym z kluczowych elementów całego sektora rolnego. Odejście od konkurencyjności na rzecz ochrony środowiska, zmiany klimatu musi jednak za sobą pociągać obawy, czy rolnicy będą akceptować te nowe zasady, godząc się być może na mniejsze zyski.

Trend godzenia jakości produkcji ze wzrostem konkurencyjności jest obserwowany już w obecnym okresie programowania. Wskazuje się, że „,wzrostowy trend popytu na produkty wysokiej jakości, wytwarzane z zachowaniem wymogów środowiskowoklimatycznych, tworzy możliwość dalszego podnoszenia konkurencyjności, a zarazem podnoszenia dochodowości producentów rolnych. Do wykorzystania tej szansy przyczyniają się nowe technologie poprawiające produktywność i jakość produktów rolnych oraz pozytywnie wpływające na stan środowiska. Kierunek zmian preferencji konsumentów pozwala również wnioskować, że szansą rozwojową dla polskich producentów, zwłaszcza tych o niewielkiej skali działania, będą produkty niszowe lub sprzedaż bezpośrednia niskoprzetworzonych produktów spożywczych, wytwarzanych w gospodarstwach rolnych" 139 .

Jakość staje się dziś ważnym uzupełnieniem konkurencyjności. W cytowanym PROW 2014-2020 wskazuje się, że ,polskie rolnictwo (podobnie jak rolnictwo europejskie) traci przewagi cenowo-kosztowe. Utrzymanie konkurencyjności produktów na rynku UE i światowym wymaga w związku z tym położenia większego nacisku na wysoką jakość. Proces poprawy jakości dotyczy zarówno zmian w produkcji rolnej, przetwórstwie, jak i dalszego rozwinięcia rynku ,produktów wysokojakościowych”. Poziom rozpoznawalności produktów wytwarzanych w systemach jakości żywności jest niski, co obecnie ogranicza możliwość uzyskania wyższych dochodów przez producentów tych produktów. W rezultacie utrzymuje się zarówno niski popyt, jak i niska podaż tych produktów" 140 .

Konkurencyjność w prawie nie jest jednoznacznym pojęciem. Używana jest ona bardziej jako określenie domyślne, pożądanego stanu rozwojowego sektora rolnego. Brak jednoznacznej definicji niewątpliwie utrudnia wszelkie analizy prawne. Ocena czy konkretny instrument prawny poprawia, czy pogarsza konkurencyjność rolnictwa, może być obarczona pierwotnym błędem, wynikającym z niezrozumienia istoty konkurencyjności. Już na tym etapie de lege ferenda należałoby postulować wypracowanie

$138 \mathrm{Zob}$. https://ec.europa.eu/agriculture/sites/agriculture/files/future-of-cap/future_of food and farming_communication_pl.pdf [data dostępu 20 grudnia 2017 r.].

139 PROW 2014-2020, s. 35.

140 Tami̇e, s. 45. 
definicji konkurencyjności. Ułatwi to rozumienie celów WPR oraz wprowadzanych dla realizacji tej polityki instrumentów.

\subsection{Podsumowanie}

Zaprezentowane w rozdziale pierwszym podejścia do teorii konkurencyjności i jej rozumienia $\mathrm{w}$ nauce oraz prawie pozwalają wysnuć kilka ogólnych obserwacji dla dalszych rozważań. Konkurencyjność nie jest pojęciem jednolitym, gdzie można by było podać tylko jedną uznaną i powszechnie akceptowalną definicję. Do tego wraz z rozwojem technologicznym pojęcie to ewoluuje, uwzględniając w kolejnych częściach jego określenia nowe elementy.

Nie istnieje obecnie jedna uznana w nauce teoria konkurencyjności, która umożliwiałaby mierzalne badania efektywności wykorzystywania środków przeznaczanych na wsparcie danego sektora. Oznacza to, że nie istnieje kompleksowy model oceny efektów wykorzystywanych środków. Istnieją różnego rodzaju mierniki (jak poziom zatrudnienia, PKB, PNB, dochodowość itp.), które pozwalają na ich podstawie sformułować pewne ogólne oceny konkurencyjności danego sektora, w tym rolnictwa. Tylko poprzez analizę tych jednostkowych wskaźników, można wysnuć wnioski co do poprawy lub pogorszenia konkurencyjności danej dziedziny życia.

Konkurencyjność rolnictwa należy rozpatrywać co najmniej w dwóch wymiarach krajowym i międzynarodowym. Inaczej będzie prezentować się konkurencyjność polskiego rolnictwa w analizie czynników krajowych, a zupełnie inaczej, jeżeli uwzględnimy instrumenty, wpływające na handel międzynarodowy. Dlatego też dla dalszych analiz wybrano najważniejsze mechanizmy prawne, które w znaczący sposób mogą oddziaływać zarówno na wewnętrzną, jak i zewnętrzną konkurencyjność rolnictwa. Wszystkie te instrumenty znajdują swoje źródło w WPR.

Niewątpliwie ważną obserwacją jest także to, że współczesna WPR nie może się rozwijać bez rzetelnych analiz ekonomicznych. Badane mechanizmy prawne będą wtedy skuteczne, kiedy będzie można zaobserwować ich rzeczywisty efekt i ocenić, czy spowodowały wzrost konkurencyjności. Niejednokrotnie poszczególne rozwiązania prawne są determinowane poprzez wynik analiz ekonomicznych.

Przedstawione teorie pozwalają wysunąć w odniesieniu do rolnictwa czynniki, które należy uznać za kluczowe w zakresie konkurencyjności. Należy do nich zaliczyć warsztat pracy rolnika (czyli ziemię), pracę, urządzenia oraz transfery finansowe przeznaczone na inwestycje. Do czynników tych w ostatnich latach zalicza się także jakość produktów, innowacyjność oraz poprawę środowiska i klimatu. Przez pryzmat tych czynników można oceniać skuteczność poszczególnych instrumentów WPR, które mają poprawić konkurencyjność. Analiza ta będzie obejmowała tylko te elementy, a to umożliwia w niektórych przypadkach uwzględnienie także innych czynników, jak 
chociażby działania o charakterze społecznym, np. renty strukturalne, czy integracyjnym, jak np. tworzenie grup producentów rolnych.

Jednym z podstawowych wniosków płynących z tego rozdziału jest konstatacja, iż konkurencyjność staje się jednym z głównych determinantów rozwoju gospodarczego. Przeznaczana pomoc na wszystkie sektory gospodarki jako jeden z ważniejszych efektów powinna uwzględniać wzrost poziomu konkurencyjności. W kolejnym rozdziale dotyczącym ewolucji WPR w podejściu do konkurencyjności, można wyraźnie zauważyć, że wzrost konkurencyjności staje się przesłanką sine qua non rozliczenia przyznanej pomocy. Bez wykazania, że środki zostały w ten sposób spożytkowane, że osiągnięto wskaźniki podnoszące konkurencyjność, pomoc ta może być zwracana. Problemem jest, że ani nauka, ani przepisy prawa nie potrafiły wykształcić mierników do badania poziomu konkurencyjności, które nie budziłyby wątpliwości.

Dla dalszych rozważań za konkurencyjność będzie przyjmowana ocena sumy zasobów czynników produkcji, poziom efektywności wykorzystania czynników produkcji, a także tempo i kierunek zmian strukturalnych oraz efektywność, będącą w związku $\mathrm{z}$ teorią rozwoju gospodarczego. Podejście to pozwoli na w miarę racjonalną ocenę poszczególnych instrumentów prawnych, zarówno w zakresie regulacji oddziałujących na rynek wewnętrzny, jak i na unormowania międzynarodowe.

Konkurencyjność w odniesieniu do każdego analizowanego instrumentu prawnego będzie badana z zastosowaniem różnych podejść. Niektóre mechanizmy, jak renty strukturalne, czy ułatwianie startu młodym rolnikom wymagają analizy zasobów ludzkich, inne działania, jak zwiększanie wartości dodanej podstawowej produkcji rolnej i leśnej, czy modernizacja gospodarstw rolnych analizy środków trwałych. Trudność w badaniu instrumentów prawnych wpływających na konkurencyjność polskiego rolnictwa polega na wieloaspektowym podejściu do całości programowania.

Prawno-ekonomiczna analiza dostępności najważniejszych zasobów pozwoliła także zidentyfikować możliwe do wykorzystania mechanizmy prawne, które mają wpływ na konkurencyjność rolnictwa. Zestawienie tendencji na rynku ziemi rolnej, czy na rynku pracy rolniczej pozwala dokonać oceny pro futuro oczekiwanych rozwiązań prawnych. 


\section{Rozdział 2}

\section{Ewolucja Wspólnej Polityki Rolnej a konkurencyjność rolnictwa}

Konkurencyjność jest kluczowym wyznacznikiem realizacji WPR. Od 1957 r. aż do dnia dzisiejszego jednym z traktatowych celów polityki rolnej jest poprawa jakości życia rolników poprzez optymalne wykorzystanie środków produkcji ${ }^{1}$. Przez kolejne okresy finansowe oraz reformy polityczno-gospodarcze państw Unii Europejskiej oraz samej Wspólnoty dobierano odpowiednie instrumenty prawne, których zadaniem było jak największe podniesienie poziomu konkurencyjności rolnictwa.

Ewolucja tych instrumentów jest następstwem decyzji politycznych dotyczących rozwoju rolnictwa. Przejście od systemu pomocy finansowej bez stawiania beneficjentom większych wymagań, po połączenie konkurencyjności z ochroną środowiska i klimatu staje się coraz większym wyzwaniem dla legislacji europejskiej. Obecnie konkurencyjność jest ważnym, ale już nie najważniejszym, czynnikiem kształtującym politykę rolną w Europie. Ewolucja konkurencyjności od głównej determinanty rozwojowej po jeden $\mathrm{z}$ ważnych celów pomocy finansowej jest efektem ponad sześćdziesięciu lat ewolucji WPR².

Różne podejścia do instrumentów prawnych wpływających na konkurencyjność rolnictwa można zaobserwować zarówno w wymiarze polityki wewnątrz Unii, jak i w relacjach z państwami trzecimi ${ }^{3}$. Instrumenty polityki handlowej w sektorze rolnym zawsze wymagały koordynacji z głównymi celami WPR. Zapewniały konkurencyjność europejskich produktów rolnych na rynkach międzynarodowych. Podpisane umowy handlowe z Kanadą, czy Japonią są nowym etapem ewolucji mechanizmów wspólnotowego rynku. Ocena, czy będą one zwiększać konkurencyjność rolnictwa w Europie, będzie wymagała czasu oraz analiz związanych nie tylko z problemami prawnymi, ale przede wszystkim z wynikami ekonomicznymi.

1 A. Lichorowicz, Wspólna Polityka Rolna, [w:] J. Barcz, Prawo Unii Europejskiej, Warszawa 2004, s. 851 i nast.

2 A. Jurcewicz, Charakterystyka wspólnej polityki rolnej, [w:] A. Jurcewicz, B. Kozłowska, E. Tomkiewicz, Polityka rolna Wspólnoty Europejskiej w świetle ustawodawstwa i orzecznictwa, Warszawa 1995, s. 50, 51.

3 A. Jurcewicz, [w:] Prawo i polityka rolna Unii Europejskiej. System prawa Unii Europejskiej. Podręcznik, A. Jurcewicz (red.), t. XXVI, Warszawa 2010, s. 32. 
W kilku ostatnich latach można zaobserwować także odchodzenie od instrumentów prawnych ukierunkowanych tylko na pomoc finansową, czy też regulujących funkcjonowanie jednolitego rynku rolnego. Coraz częstszym zjawiskiem staje się wprowadzanie regulacji o charakterze soft law ${ }^{4}$, które ma oddziaływać na rynek i rolnictwo Takim przykładem są przywołane w rozdziale pierwszym rezolucja Parlamentu Europejskiego o ułatwieniach w dostępie do ziemi rolnej, czy komunikat Komisji Europejskiej, będący odpowiedzią na te zagadnienia. Takie podejście może być zjawiskiem powszechnym, umożliwiającym realizowanie polityki rolnej, niezależne od przeznaczanych na nią funduszy.

Poniższa analiza ewolucji WPR w zakresie podejścia do rozumienia i określenia prawnego konkurencyjności stanowi tylko wyimek ze złożonej problematyki oddziaływania polityki rolnej na działalność rolniczą. Zaprezentowane podejścia w ewolucji ogólnych celów WPR znajdowały swoje odzwierciedlenie w podejmowaniu konkretnych decyzji legislacyjnych, które determinowały wybór odpowiednich mechanizmów prawnych.

\subsection{Powstanie Wspólnej Polityki Rolnej i założeń konkurencyjności rolnictwa}

Podpisany 24 marca 1957 r. tzw. Traktat Rzymski określił w art. 39 ust. 1 cele WPR ${ }^{6}$. Od tego czasu nie uległy one co do zasady zmianie w swojej językowej treści. W zakresie konkurencyjności na pierwsze miejsce wysuwa się cel określony w art. 39 ust. 1 lit. a Traktatu, w którym podkreślono, że celem WPR jest ,Zwiększenie wydajności rolnictwa przez wspieranie postępu technicznego, racjonalny rozwój produkcji rolnej, jak również optymalne wykorzystanie czynników produkcji, zwłaszcza siły roboczej"7. Głównym zadaniem w tym okresie okazało się stymulowanie wzrostu produkcji rolnej przede wszystkim w obliczu niedoborów żywności. Miały służyć temu także inne cele WPR określone w Traktacie.

4 A. Jurcewicz, Soft law w prawie Wspólnot Europejskich, „Przegląd Legislacyjny”, 1997, nr 4, s. 31-44; M. Zirk-Sadowski, Wykladnia i rozumienie prawa w Polsce po akcesji do Unii Europejskiej, [w:] Polska kultura prawna a proces integracji europejskiej, S. Wronkowska (red.), Kraków 2005; A. Jurcewicz, Rola ,miękkiego prawa” w praktyce i instytucjach Wspólnoty Europejskiej, [w:] Implementacja prawa integracji europejskiej w krajowych porzadkach prawnych, C. Mik (red.), Toruń 1998, s. 111 i nast.

5 Por. wyrok TS z dnia 7 marca 1972 r. sprawie 84/71 SpA Marimex przeciwko Ministero delle Finanze, Zb. Orz. 1972, s. 89.

6 Zob. https://eur-lex.europa.eu/legal-content/DE/TXT/PDF/?uri=CELEX:11957E/TXT\&from=PL [data dostępu 27 marca 2019].

7 Do pozostałych celów WPR w art. 39 ust. 1 TFUE zaliczono: ,zapewnienie w ten sposób odpowiedniego poziomu życia ludności wiejskiej, zwłaszcza przez podniesienie indywidualnego dochodu osób pracujących w rolnictwie; stabilizacja rynków; zagwarantowanie bezpieczeństwa dostaw; zapewnienie rozsądnych cen w dostawach dla konsumentów". 
We wstępnej fazie realizacji celów WPR najprostszym instrumentem prawnym, który miał pomóc rolnikom okazały się dotacje cen środków produkcji. Stosowane były one jako mechanizm wspierający jeszcze przed formalnym ustanowieniem WPR. Szybko jednak z nich zrezygnowano, ustanawiając jednolite ceny na produkty rolnicze. Ten mechanizm miał ułatwić konkurowanie rolników ze Wspólnoty pomiędzy sobą i zapewnić odpowiedni poziom dochodów rolniczych.

Ustanowiono w tym czasie także podstawowe zasady rynku wspólnotowego, które są obowiązujące do chwili obecnej. Można do nich zaliczyć zasadę preferencji Unii Europejskiej, zgodnie z którą produkty pochodzące z państw członkowskich mają pierwszeństwo przed produktami państw trzecich ${ }^{8}$. Zasada ta jest podstawą dla funkcjonowania instrumentów wspierających konkurencyjność na jednolitym wspólnym rynku europejskim. Pozwala wypracować takie mechanizmy, jak: limitowanie eksportu i importu, określenie cen na produkty rolne, wprowadzenie certyfikatów oraz norm jakościowych. Przykładowe powyższe wyliczenie możliwych mechanizmów prawnych, wypływających z zasady preferencji europejskiej, nie wyczerpuje różności konstrukcji prawnych stosowanych od 1957 r. dla realizacji tej zasady. Należy ją uznać za nadrzędną zasadę WPR.

Drugą z zasad WPR stała się zasada solidarności. Rozumie się ją jako solidarny udział każdego państwa członkowskiego w finansowaniu WPR. Pozwala ona także zapewnić bezpieczeństwo finansowe rolnictwa oraz możliwość uzyskania pomocy z budżetu wspólnotowego w przypadku zdarzeń losowych. Zasada ta znajduje swoje odzwierciedlenie chociażby w takich instrumentach prawnych, które dopuszczają pomoc publiczną w sytuacji, gdy na rynku danego produktu rolnego dochodzi do zdarzeń obiektywnie niekorzystnych ekonomicznie. Przykładem tego są chociażby mechanizmy prawne uruchamiane w sytuacji wystąpienia różnych chorób odzwierzęcych, jak ptasia grypa, czy ASF9. Dzięki zasadzie solidarności UE może reagować na załamanie rynku danego produktu rolnego i utrzymać w tym zakresie wzrost konkurencyjności w dłuższej perfektywnie czasowej. Zasada ta wypracowana w 1957 r. jest aktualna do dnia dzisiejszego, a wraz z pojawianiem się nowych zagrożeń, zyskuje na aktualności.

Za trzecią zasadę WPR uznaje się zasadę jednolitego rynku. Pozwala ona na równe traktowanie producentów rolnych ze wszystkich krajów UE. Doprowadziło to do zniesienia ograniczeń wewnętrznych na rynku produktów rolnych Wspólnoty. Przede

8 G. Theimeyer, The failure of Green Pool and the success of the CAP, [w:] Fertile Ground for Europe? The History of European Integration and the Common Agricultural Policy science 1945, K.K. Patel (red.), Baden-Baden 2009, s. 50-52.

9 Afrykański pomór świń (African Swine Fever); J.M. Sánchez-Vizcaíno, L. Mur, B. Martínez-López, African swine fever (ASF): five years around Europe, „Veterinary Microbiology”, 2013, nr 165, s. 45-50; Z. Pejsak, M. Pomorska-Mól, Program eradykacji wirusa afrykańskiego pomoru świń realizowany w Hiszpanii w latach 1985-1995, „Życie Weterynaryjne”, 2018, nr 93, s. 96-99; M. Flis, Nowe rozwiazania prawno-administracyjne w zakresie zwalczania afrykańskiego pomoru świń, „Życie Weterynaryjne”, 2018 nr 93, s. 93-95; rozporządzenie Ministra Rolnictwa i Rozwoju Wsi z dnia 31 marca 2014 r. w sprawie środków podejmowanych w związku z wystąpieniem u dzików afrykańskiego pomoru świń (Dz. U. poz. 420). 
wszystkim zlikwidowano cła, ograniczenia ilościowe w przepływie produktów rolnych i żywnościowych, czy też wprowadzono jednolite normy jakościowe.

Te trzy zasady wypracowane wraz z określeniem celów WPR są wyznacznikiem wszystkich kolejnych analizowanych instrumentów prawnych, które mają przyczynić się do wzrostu konkurencyjności w rolnictwie. Dlatego też dokonując kolejnych ocen prawnych, trzeba je analizować poprzez pryzmat zasad WPR oraz traktatowych celów.

Wypracowane w Traktacie Rzymskim cele WPR przyczyniły się do koncentracji czynników produkcji poprzez wsparcie postępu technicznego w rolnictwie. Ponadto, nie powstrzymały odpływu siły roboczej z rolnictwa do przemysłu. Industrializacja gospodarki w tym zakresie wymogła w kolejnych okresach finansowych wypracowanie nowych instrumentów, zachęcających rolników do pozostawania w gospodarstwach rolnych. Nastąpił również wzrost podaży surowców rolniczych, a to zapewniło stopniowy wzrost dochodów rolniczych.

Pierwotne instrumenty WPR miały przyczynić się do zaspokojenia potrzeb żywnościowych Europy. Stosowane mechanizmy dotacji produkcji rolnej tylko częściowo pozwoliły na podniesienie poziomu konkurencyjności rolników mierzonej wzrostem dochodowości prowadzonej działalności rolniczej. Konkurencyjność w tym okresie miała zapewnić UE samowystarczalność żywnościową. Efekty tej działalności nie były jednakże dość zadowalające. Dlatego też w kolejnych perspektywach finansowych zaczęto poszukiwać bardziej zaawansowanych instrumentów pomocowych.

Trzeba jednakże podkreślić, że wypracowane w tym okresie zasady WPR i normatywnie ujęte $\mathrm{w}$ Traktacie cele WPR pozostały w swojej treści niezmienione do dnia dzisiejszego. Kolejne etapy ewolucji tej polityki polegały na określeniu nowych instrumentów prawnych i ekonomicznych, które miały te cele urzeczywistnić. Proces ten trwa nadal.

\subsection{Mechanizmy protekcjonistyczne Wspólnej Polityki Rolnej}

Zastosowane instrumenty prawne zaczęły poprawiać sytuacje $\mathrm{w}$ rolnictwie ${ }^{10}$. Jednocześnie pojawił się wzrost podaży na żywność. Łącznie zaczęły się obniżać dochody rolnicze ${ }^{11}$. Ponadto, względny powojenny spokój umożliwił zwiększenie importu tańszej żywności spoza UE ${ }^{12}$. Te czynniki zewnętrzne skłoniły UE do poszukiwania nowych instrumentów prawnych, mających za zadanie realizację WPR, podniesienie konkurencyjności i długotrwałą poprawę sytuacji rolników.

10 A. Jurcewicz, B. Kozłowska, E. Tomkiewicz, Wspólna Polityka Rolna. Zagadnienia prawne, Warszawa 2006.

11 A. Wiatrak, Dochody ludności rolniczej (tworzenie, podziat, funkcje), „Ruch Prawniczy, Ekonomiczny i Socjologiczny”, 1981, z. 1.

12 M. Mikołajczyk, Francuska batalia o wspólna politykę rolna w okresie rządów generała Charles'a de Gaulle'a w latach 1958-1969, „Przegląd Zachodni”, 2014, t. 4, nr 353, s. 218-239. 
W takiej sytuacji ekonomicznej zaczęto wprowadzać mechanizmy interwencjonizmu państwowego o charakterze protekcjonistycznym. Miały one na celu ochronę cen i stabilizację rynku. Ponadto, nowe podejście w WPR miało wspomóc dochody rolnicze. Sam protekcjonizm i ingerencja w wolny rynek kłóciła się z zasadą liberalnego handlu stosowanego w innych sektorach gospodarki. Trzeba podkreślić, że rolnictwo było zawsze, a w tym okresie szczególnie, traktowane jako sektor o doniosłym znaczeniu gospodarczym oraz społecznym. Zapewnienie wyżywienia ludności Europy poprzez pomoc producentom rolnym stało się jednym z kluczowych wyznaczników okresu silnego protekcjonizmu europejskiego w polityce rolnej.

Zaczęto stosować takie instrumenty prawne jak ceny gwarantowane na produkty rolne. Miały one zapewnić stały dochód rolnikom ${ }^{13}$ i umożliwić zbyt produkowanej żywności. Gwarantowały również preferencyjne warunki zbytu, niwelując różnice w dochodach producentów. Były one ustalane administracyjnie co roku na poziomie wyższym niż światowy.

Ponadto, wprowadzono opłaty wyrównawcze ${ }^{14}$ poprzez Plan Mansholta ${ }^{15}$ w $1960 \mathrm{r}$. do dochodów rolniczych. Opłaty te miały pobudzić handel międzynarodowy pomiędzy UE a krajami trzecimi. W zmienionej formie są stosowane one do chwili obecnej jako jeden z instrumentów wspólnego rynku produktów rolnych. Opłaty wyrównawcze zostały wsparte mechanizmem subsydiów eksportowych ${ }^{16}$. Pozwoliło to na zwiększenie produkcji żywności, a co za tym idzie podniesienie dochodów rolniczych.

Jednym z ważniejszych instrumentów prawnych wprowadzonych w tym okresie było wsparcie dla gospodarstw na obszarach o niekorzystnych warunkach gospodarowania, a także na obszarach dzierżawionych ${ }^{17}$. Mechanizm ten przetrwał do dnia dzisiejszego. Jego zadaniem jest pomoc finansowa dla rolników, którzy prowadzą swoją działalność na obszarach, które uniemożliwiają lub utrudniają produkcję rolniczą.

13 M. Podstawka, A. Ginter, Sytuacja dochodowa gospodarstw rolniczych w warunkach różnego poziomu rozwoju rolnictwa, „Roczniki Naukowe Stowarzyszenia Ekonomistów Rolnictwa i Agrobiznesu SERiA", 2006, t. 8, z. 1. Informacje o dochodach rolniczych są zbierane w systemie FADN.

14 Opłaty wyrównawcze należy rozumieć jako różnicę między niższą ceną towaru importowanego a wyższą, ustaloną i gwarantowaną przez państwo ceną wewnętrzną towaru produkowanego w kraju. Podstawowym celem jest podniesienie ceny towaru importowanego do poziomu ceny towaru krajowego w celu zrównania ich konkurencyjności. Opłaty wyrównawcze są zmienne, ponieważ zależą od wahań cen na rynku międzynarodowym towarów importowanych. W przypadku, gdy ceny ulegają obniżeniu opłaty wyrównawcze rosną, w przypadku przeciwnym - maleją.

15 S. Mansholt, The Mansholt Plan, „Studies: An Irish Quarterly Review”, 1970, nr 59, s. 404-418.

$16 \mathrm{~K}$. Więznowska, Wspólna polityka rolna-instrumenty interwencji, „Prace Naukowe Akademii Ekonomicznej we Wrocławiu", 2002, nr 958, s. 167-173.

17 A. Lichorowicz, Potrzeba prawnego uregulowania dzierżawy rolnej w Polsce (na podstawie doświadczeń krajów Unii Europejskiej), „Przegląd Prawa Rolnego”, 2010, t. 7, nr 2, s. 63-78; J. Nadler, Dzierżawa, [w:] Komentarz do Kodeksu cywilnego, E. Gniewek (red.), Warszawa 2011; W. Pańko, Dzierżawa gruntów rolnych, Warszawa 1975. 
Efektem podejmowanych działań była koncentracja w rolnictwie i powstawanie wyspecjalizowanych ferm ${ }^{18}$. Sprzyjała temu intensyfikacja produkcji ze względu na postęp chemiczny i biologiczny. Zastosowane mechanizmy pozwoliły także na wzrost podaży surowców rolniczych i żywności.

W 1961 r. uzupełniono Plan Mansholta ${ }^{19}$ o kwestie socjalne. Dotyczyły one przede wszystkim wsparcia edukacji młodzieży wiejskiej oraz organizowania szkoleń dla rolników, którzy zrezygnują z prowadzenia działalności rolniczej. Mechanizmy te nie były zorientowane wprost na podnoszenie konkurencyjności, ale miały wpłynąć na jakość prowadzonej produkcji poprzez podnoszenie kwalifikacji rolniczych. Część $\mathrm{z}$ tych instrumentów w zmienionej formie jest stosowana także w obecnej perspektywie finansowej.

Rok później - w 1962 roku podpisano porozumienia, na mocy których powstał wspólnotowy rynek zbóż, wieprzowiny, drobiu, owoców i warzyw. Zaczęto tworzyć także pierwsze elementy rynku wina. Powstanie zasad dotyczących organizacji rynków rolnych było ważnym wyznacznikiem w handlu z państwami trzecimi. Dalsza ewolucja systemu wspólnego rynku rolnego polegała na dołączaniu kolejnych sektorów do tych reguł i wypracowaniu jednolitych instrumentów prawnych ${ }^{20}$.

Zwieńczeniem tego okresu ewolucji WPR w odniesieniu do konkurencyjności było utworzenie w kwietniu 1964 r. Europejskiego Funduszu Orientacji i Gwarancji Rolnej ${ }^{21}$, który stanowił podstawę rozwoju obszarów wiejskich aż do 2007 r. Finansowane działania poprzez funkcjonowanie tego funduszu w wydatny sposób przyczyniły się do wzrostu konkurencyjności rolnictwa.

\subsection{Instrumenty prawno-organizacyjne ograniczenia produkcji rolnej}

Wprowadzone mechanizmy wsparcia o charakterze protekcjonistycznym w dłuższym okresie nie dały zadowalających efektów ${ }^{22}$. Pojawiły się nadwyżki żywności i rosnące koszty ich zagospodarowania. Ponadto, rolnictwo europejskie nadal

18 A. Lichorowicz, O instytucji rodzinnego gospodarstwa rolnego-de lege ferenda, „Rejent”, 1996 , nr 7-8, s. 31-50.

19 D.R. Stead, The Mansholt Plan Forty Years On Le plan Mansholt quarante ans après Der Mansholt-Plan vierzig Jahre später, „EuroChoices”, 2007, nr 63, s. 40-45; M. Petit, Michel, J.B. Viallon, Reflexions sur le plan Mansholt, „Economie rurale”, 1970, nr 86, s. 43-50.

20 L. Costato, Wplyw wspólnotowego prawa rolnego na prawo rolne wewnętrzne, „Przegląd Prawa Rolnego", 2007, nr 1, s. 12-25.

21 R. Zwierzchoniewski, Europejski Fundusz Orientacji i Gwarancji Rolnej [FEOGA]. Informator, Ośrodek Doradztwa Rolniczego Bonin, 1993; J. Wilkin, Kierunki i uwarunkowania wykorzystania instrumentów Wspólnej Polityki Rolnej w odniesieniu do polskiego rolnictwa i obszarów wiejskich, „Wieś i Rolnictwo", 2003, nr 1, s. 50-74.

22 Resolution on the New Guidelines for the Common Agricultural Policy z 25 maja 1971 r. (Dz. Urz. C 52 z 27.05.1971, s. 1). 
cechowały wysokie koszty produkcji, a przez to istniała mała szansa na konkurowanie z gospodarkami państw trzecich. Wprowadzone dotacje i subwencje w eksporcie oraz imporcie nie osiągnęły zakładanego celu.

Dość słaba integracja pomiędzy poszczególnymi państwami UE powodowała dalszą konkurencję pomiędzy członkami Wspólnoty. Zwiększenie intensywnej produkcji rolnej spowodowało także niekorzystne oddziaływanie na środowisko przyrodnicze. W tych warunkach należało poszukać nowych instrumentów prawnych, które realizując cele WPR będą powodowały wzrost konkurencyjności rolnictwa europejskiego.

Za cel główny w tym okresie postawiono sobie zmniejszenie nadwyżek produktów rolniczych oraz stabilizację rynków. Wykorzystano do tego opłaty współodpowiedzialności ${ }^{23}$ (coresponsibility levy) ${ }^{24}$. Zaczęto również wprowadzać mechanizmy ograniczające produkcję rolną, określając wielkość produkcji, powyżej której nie przysługuje cena gwarantowana ${ }^{25}$. Pozostawiając nadal mechanizmy o charakterze protekcjonistycznym próbowano ograniczać produkcję rolną, zniechęcając rolników do produkowania ponad określone, opłacalne pułapy. Po raz pierwszy w tym okresie (w 1984 r.) wykorzystano instrument kwot mlecznych ${ }^{26}$. Mechanizm ten przetrwał następne kilkadziesiąt lat ${ }^{27}$.

Ograniczanie produkcji początkowo obejmowało tylko niektóre produkty, które ze względu na powszechność występowania miały znaczący wpływ na poziom

23 W. Osdoba, Ksztaltowanie jednolitej wspólnej regulacji rynków rolnych w Unii Europejskiej i Polsce, „Studia Iuridica”, 2017, t. 72, s. 295-308.

24 J.L. Hubbard, The co-responsibility levy a misnomer?, „Food Policy”, 1986, nr 11, s. 197-201; H. De Gorter, Harry, K.D. Meilke, Efficiency of alternative policies for the EC's Common Agricultural Policy, „American Journal of Agricultural Economics”, 1989, nr 71, s. 592-603.

25 A. Kowalski, W. Rembisz, Ekonomia polityczna ryzyka cenowego w rolnictwie, [w:] Ryzyko w gospodarce żywnościowej - teoria i praktyka, J. Góral, M. Wigier (red.), Warszawa 2017.

26 A. Suchoń, Rechtliche und ökonomische Aspekte des Milchmarkts in Polen - aktueller Stand und Entwicklungsperspektiven, „Agrar und Umweltrecht”, 2014, z. 1; R. Grochowska, Niespójność dziatań interwencyjnych na unijnym rynku mleka, „Zeszyty Naukowe Szkoły Głównej Gospodarstwa Wiejskiego w Warszawie Problemy Rolnictwa Światowego”, 2017, t. 17, nr 32, z. 3, s. 93-100; J. Bieluk, D. Łobos-Kotowska, Kwoty mleczne jako przedmiot obrotu - wybrane zagadnienia, „Studia Iuridica Agraria”, Białystok 2011, t. 9, s. 294-305; A. Suchoń, Dairy cooperatives as milk purchasing and processing entities in a milk products supply chain, „Logistyka”, 2014, nr 6, s. 13790-13793; A. Oleszko, „Dziedziczenie” kwot produkcyjnych oraz płatności w rolnictwie, [w:] „Annales Universitatis Mariae Curie-Skłodowska", Lublin, vol. LII/LIII, sectio G, 2005-2006.

27 A. Suchoń, Funkcjonowanie rynku mleka po likwidacji kwotowania - wybrane aspekty prawne, „Studia Iuridica Agraria”, Białystok 2016, t. 14, s. 297-313; A. Baer-Nawrocka, E. Kiryluk-Dryjska, Wpływ likwidacji kwot mlecznych na sytuacje produkcyjna i ekonomiczna producentów mleka w Unii Europejskiej (wyniki symulacji modelowych), „Wieś i Rolnictwo”, 2010, nr 3; P. Szajner, Wplyw likwidacji kwot mlecznych $i$ zmian regulacji rynku mleka na perspektywy rozwoju polskiego mleczarstwa, IERiGŻ, s. 12; P. Szajner, Ocena wpływu likwidacji kwot mlecznych na konkurencyjność polskiego mleczarstwa w kontekście teorii ekonomii, „Zeszyty Naukowe Szkoły Głównej Gospodarstwa Wiejskiego w Warszawie. Problemy Rolnictwa Światowego“, 2012, t. 12, nr 27, s. 104-112. 
dochodów rolniczych. Mechanizm oddziaływania na produkcję rolną poprzez kształtowanie jej wielkości determinował rozwój takich rynków, jak mleka, cukru, czy skrobi ziemniaczanej. Limitowanie produktów dotyczyło także eksportu i importu. Pomimo wprowadzania stopniowych mechanizmów liberalizujących rynek rolny nadal konkurencyjność rolnictwa była uzależniona od silnych oddziaływań protekcjonistycznych.

\subsection{Reforma MacSharry'ego, czyli odejście od silnego protekcjonizmu}

Instrumenty o charakterze stricte protekcjonistycznym wraz z rozwojem gospodarczym przestały spełniać swoją rolę przede wszystkim ze względu na wysokie koszty i absorbcję znacznych środków budżetowych ${ }^{28}$. Duże znaczenie dla dalszego rozwoju instrumentów prawnych WPR, wpływających na konkurencyjność rolnictwa, miały czynniki zewnętrzne. Przede wszystkim negocjacje związane z GATT29 i reorientacją polityki handlowej na świecie ${ }^{30}$.

Prowadzona dotychczas polityka protekcjonistyczna oraz ograniczenie produkcji doprowadziło do zmniejszenia nadwyżek żywności. WPR stanęła przed koniecznością dywersyfikacji produkcji oraz podtrzymania dochodów rolniczych, nie tylko poprzez mechanizmy cenowe ${ }^{31}$.

W 1992 r. Ray MacSharry zgłosił projekt reformy WPR. Celem nowego podejścia miała być poprawa równowagi na rynkach rolnych; bardziej ekstensywne sposoby gospodarowania (w celu ochrony środowiska i likwidacji nadwyżek); redystrybucja dochodów na korzyść drobnych gospodarstw oraz wzmocnienie wewnętrznej i zewnętrznej konkurencyjności cenowej ${ }^{32}$.

Głównym instrumentem w handlu międzynarodowym stały się cła, które zastąpiły opłaty wyrównawcze ${ }^{33}$. Jednocześnie zredukowano stawki celne i subsydia eksportowe. Wprowadzono jeden z głównych mechanizmów prawnych współczesnego

28 M. Błąd, Reformy wspólnej polityki rolnej w Unii Europejskiej w latach dziewięćdziesiątych, „Acta Scientifica Academiae Ostroviensis”, 2000, nr 6.

29 A. Hajdukiewicz, Kierunki zmian Wspólnej Polityki Rolnej Unii Europejskiej w kontekście negocjacji handlowych na forum WTO i Brexitu, „Horyzonty Polityki”, 2017, nr 8, s. 109-130; K. Marciniuk, Rolnictwo wobec integracji europejskiej i globalizacji. Problematyka prawna, Warszawa 2013.

30 R. Budzinowski, Międzynarodowy czynnik rozwoju prawa rolnego, „Przegląd Prawa Rolnego”, 2007, nr 2, s. 28-44.

31 S. Kowalski, Realizacja wspólnej polityki rolnej Unii Europejskiej i jej konsekwencje dla europejskiego rolnictwa, ,Zeszyty Naukowe PWSZ w Płocku. Nauki Ekonomiczne”, 2017, t. 25.

32 A. Czyżewski, Ł. Wawrzyniak, Wspólna Polityka Rolna Unii Europejskiej po reformie MacSharry'ego $w$ warunkach różnych opcji polityki gospodarczej, ,Wieś i Rolnictwo”, 2004, nr 4, s. 31.

33 F. Tomczak, Ewolucja wspólnej polityki rolnej UE i strategia rozwoju rolnictwa polskiego, Warszawa 2009. 
rolnictwa - system dopłat kompensacyjnych ${ }^{34}$. Aktualnie ich rolę pełnią płatności bezpośrednie ${ }^{35}$. Uzyskiwane z nich dochody dla rolników stanowią jedną z głównych podstaw wzrostu konkurencyjności rolnictwa.

Wraz z nową reformą wprowadzono oddziaływanie na politykę demograficzną na wsi. Zaczęto stosować system wczesnych emerytów w celu poprawy struktury obszarowej. W późniejszym okresie instrumentem tym były renty strukturalne ${ }^{36}$. Zaczęto stosować zachęty do ekstensyfikacji produkcji rolnej, w czym obecnie można upatrywać początków polityki proekologicznej UE ${ }^{37}$.

Efektem prowadzonej reformy było obniżenie cen produktów rolnych, częściowa ekstensyfikacja produkcji rolniczej, początek odłogowania ziemi oraz stabilizacja dochodów rolniczych poprzez system kompensacji ${ }^{38}$. Zapewnienie rolnikom w wyni$\mathrm{ku}$ tych reform minimum potrzebnego dla prowadzenia działalności rolniczej było jednym z przełomowych działań poprawiających konkurencyjność rolnictwa. Jednocześnie reforma aktywizowała rolników. Powodowała, że musieli zacząć przedstawiać biznesowe założenia swojej działalności, a pomoc była bardziej ukierunkowana na konkretne działania inwestycyjne.

\subsection{Polityka rozwoju obszarów wiejskich i polityka prośrodowiskowa}

Prowadzona reforma MacSharry'ego przyniosła ograniczone efekty ekstensyfikacji produkcji. Finansowanie rolnictwa i jego rozwój przyniosły obserwowalne zagrożenia dla środowiska naturalnego ${ }^{39}$. Dlatego też podjęto próbę określenia na nowo instrumentów prawnych realizujących cele WPR.

Dlatego też w 1997 r. przedłożono pakiet reform zwany Agendą 2000. Zakładał on podniesienie konkurencyjności na rynku wewnętrznym i zagranicznym. Jednym z głównych celów WPR stało się bezpieczeństwo i jakość żywności. Odejście od

34 A. Germano, Reforma Wspólnej Polityki Rolnej w 2003 r. i reżim platności jednolitej, „Przegląd Prawa Rolnego", 2007, nr 1, s. 49.

35 J. Bieluk, D. Łobos-Kotowska, Płatności bezpośrednie, [w:] Prawo rolne, P. Czechowski (red.), Warszawa 2015.

36 T. Kurowska, Zadania i funkcje instrumentów prawnych wspierania rozwoju obszarów wiejskich, „Studia Iuridica Agraria”, Białystok 2005, t. 4.

37 P. Gała, Ochrona bioróżnorodności jako determinanta Wspólnej Polityki Rolnej, „Studia Iuridica Lublinensia”, 2017, t. 26, s. 193-209; M.A. Król, Ekologizacja Wspólnej Polityki Rolnej - zagadnienia prawne, „Zeszyty Naukowe Szkoły Głównej Gospodarstwa Wiejskiego w Warszawie. Polityki Europejskie, Finanse i Marketing", 2013, t. 59, nr 10, s. 402-421; A. Lichorowicz, Problematyka struktur agrarnych w ustawodawstwie Wspólnoty Europejskiej, Kraków 1996, s. 152-154.

38 J. Bieluk, Zmiana paradygmatu prawa rolnego, ,Studia Iuridica Agraria”, Białystok 2015, t. 13, s. $65-76$.

39 A. Bołtromiuk, Przyczyny i skutki wzrostu zainteresowania aspektem środowiskowym w polityce rolnej UE, „Roczniki Naukowe SERiA”, 2006, t. 8, z. 4. 
kryteriów ilościowych jest stosowane do chwili obecnej. Podjęto próbę stabilizacji dochodów rolniczych, a także tworzenia pozarolniczych źródeł dochodów. W końcu założono zintegrowanie z celami i działaniami WPR celów ochrony środowiska przyrodniczego.

Jedną z podstawowych spraw uczyniono reformę systemu płatności bezpośrednich. Wprowadzono ich uproszczenie i oderwanie od produkcji (decoupling) ${ }^{40}$. Określono zasady wzajemnej zgodności ${ }^{41}$ (cross compliance) ${ }^{42}$. Pozwalały one na spełnienie minimalnych wymagan $\mathrm{w}$ zakresie ochrony środowiska ${ }^{43}$ oraz dobrostanu zwierząt. $\mathrm{Z}$ czasem stały się podstawowym instrumentem prawnym, który stanowił warunek konieczny do spełnienia w celu ubiegania się o środki finansowe. Zasady wzajemnej zgodności stały się także mechanizmem, który jest gwarantem minimalnych standardów zachowywanych w działalności rolniczej. Niewątpliwie wpisywały się w politykę poprawy jakości produktów rolnych i żywnościowych. Zaczęto również stosować mechanizm modulacji ${ }^{44}$ płatności bezpośrednich ${ }^{45}$.

Reforma wprowadzana w ramach Agendy 2000 pozwoliła na rozpoczęcie finansowania projektów, które miały na celu ochronę środowiska naturalnego w procesie produkcji rolnej. Przede wszystkim zaczęto wprowadzać programy rolnośrodowiskowe ${ }^{46}$. Premiowały one rolników, którzy w ramach swojej działalności stosowali specjalne

40 D. Moro, P. Sckokai, Modelling the CAP arable crop regime in Italy: degree of decoupling and impact of Agenda 2000, „Cahiers d'Economie et de Sociologie Rurales”, 1998, nr 53, s. 49-73; O. Balkhausen, M. Banse, H. Grethe, Modelling CAP decoupling in the EU: a comparison of selected simulation models and results, „Journal of Agricultural Economics”, 2008, nr 59, s. 57-71.

41 M.A. Król, ,Zasada wzajemnej zgodności” - nowy instrument ochrony środowiska, [w:] Dekada harmonizacji w prawie ochrony środowiska, M. Rudnicki, A. Haładyj, K. Sobieraj (red.), Lublin 2011.

42 B. Jeżyńska, Znaczenie i funkcje zasady cross-compliance $w$ systemie rolniczych dopłat bezpośrednich, „Studia Iuridica Lublinensia”, 2010, t. 13, s. 35-50; A. Hawrylewicz-Łuka, Spetnianie wymogów wzajemnej zgodności (cross-compliance) przy ubieganiu się przez rolników o płatności bezpośrednie jako poszanowanie środowiska naturalnego, [w:] Administracja publiczna - człowiek a ochrona środowiska. Zagadnienia społeczno-prawne, M. Górski, J. Bucińska, M. Niedziółka, R. Stec, D. Strus (red.), Warszawa 2011, s. 130-155; A. Korycińska, Przyszłość cross-compliance w świetle dyskusji o systemie płatności bezpośrednich po 2013 r., Warszawa 2009.

43 M.A. Król, Środowiskowy wymiar płatności w ramach systemów wsparcia bezpośredniego - zagadnienia prawne, [w:] Prawne instrumenty ochrony środowiska, B. Jeżyńska, E. Kruk (red.), Lublin 2016, s. 295 i nast.

44 D. Milanowska, Instrument modulacji w nowym systemie dopłat bezpośrednich, „Studia Iuridica Agraria", Białystok, 2007, t. 6.

45 D. Żmija, System płatności bezpośrednich $w$ Polsce $w$ kontekście rozwiazań stosowanych $w$ Unii Europejskiej, „Problems of World Agriculture/Problemy Rolnictwa Światowego”, 2011, t. 11, z. 1, s. 193-201.

46 M.A. Król, Rola programów rolnośrodowiskowych w ochronie obszarów cennych pod względem przyrodniczym, „Studia Prawno-Ekonomiczne”, 2012, nr 86, s. 67-91; T. Marcysiak, P. Prus, Programy rolnośrodowiskowe jako instrument zrównoważonej modernizacji rolnictwa i obszarów wiejskich na przykładzie wybranych krajów UE, „Zeszyty Naukowe Szkoły Głównej Gospodarstwa Wiejskiego w Warszawie. Polityki Europejskie, Finanse i Marketing”, 2009, nr 2. 
praktyki zwiększające nie tylko poziom ekologizacji ich produktów rolnych, ale także były przyjazne środowisku ${ }^{47}$.

Przeorientowanie polityki od wsparcia produkcji rolnej i żywnościowej w kierunku jakości wytwarzanych produktów jest zmianą wpływającą na konkurencyjność rolnictwa ${ }^{48}$. Od Agendy 2000 rolnictwo europejskie konkuruje nie tylko ilością wytwarzanych produktów, ale także ich jakością i bezpieczeństwem. Większego znaczenia nabrały także aspekty środowiskowe i ekologiczne ${ }^{49}$.

\subsection{Zazielenienie jako kierunek rozwoju Wspólnej Polityki Rolnej}

Zmiany WPR wymusiła kolejna perspektywa finansowa. Agenda 2000, inicjując odejście od dotychczasowych mechanizmów wsparcia zainicjowała nowy kierunek WPR premiujący gospodarstwa rolne ${ }^{50}$, które przy inwestycjach oraz podczas prowadzenia działalności rolniczej będą uwzględniały wymogi środowiskowe ${ }^{51}$.

Nowe podejście do realizacji celów WPR zbiegło się z malejącą akceptacją społeczeństwa UE dla WPR ${ }^{52}$, która skupiała się wyłącznie na wspomaganiu dochodów rolniczych. Europejczycy chcieli mieć również z polityki rolnej wymierne efekty oddziałujące na całe społeczeństwo ${ }^{53}$. Związane to było nie tylko z nowym budżetem UE, lecz także ze zmianami w polityce energetycznej UE, nastawionej na ochronę środowiska naturalnego. Rolnictwo w tym zakresie nie mogło być gorszym sektorem, postanowiono zatem wypracować mechanizmy wsparcia, które będą chroniły nie tylko środowisko, lecz także klimat. Postęp wprowadzanych zmian został niejako wymuszony presją międzynarodową, związaną z pełną realizacją postanowień GATT i WTO.

47 A. Klisowska, Miejsce programów rolnośrodowiskowych w polityce rolnej po integracji Polski z Unia Europejska, „Wieś i Rolnictwo”, 2001, nr 3.

48 J. Miecznikowska, Dyskusja nad kształtem Wspólnej Polityki Rolnej a ocena funkcjonowania reformy z lat 2003-2004, „Przegląd Europejski”, 2008, nr 1.

49 A. Kaźmierska-Patrzyczna, M.A. Król, Prawne instrumenty ochrony krajobrazu wiejskiego w ramach systemów wsparcia bezpośredniego do gruntów rolnych oraz rozwoju obszarów wiejskich na lata 2014-2020, „Acta Universitatis Carolinae - Iuridica”, 2015, $\mathrm{nr} 2$.

50 W. Poczta, Wspólna Polityka Rolna po 2013 roku - wizja zmian, [w:] Projekty inwestycyjne w agrobiznesie a zasady Wspólnej Polityki Rolnej po 2013 roku, A. Czyżewski, W. Poczta (red.), Poznań 2011.

51 M.A. Król, Legal protection framework of environmental law for agricultural production in Poland, „Zeszyty Naukowe SGGW. Polityki Europejskie, Finanse i Marketing” 2015, t. 62, nr 13; A. Jurcewicz, E. Tomkiewicz, Wspólna Polityka Rolna po 2013 r., [w:] Z zagadnień prawa rolnego, cywilnego i samorzadu terytorialnego. Ksiegga jubileuszowa Profesora Stanisława Prutisa, T. Mróz, J. Bieluk, A. Doliwa, A. Malarewicz-Jakubów (red.), Białystok 2012, s. 106 i nast.

52 Ogólna ocena pakietu legislacyjnego WPR na lata 2014-2020 i zatożenia do Stanowiska Rza$d u R P$, s. $1-5$.

53 M.A. Król, Przejawy europeizacji w prawie rolnym, „Studia Iuridica Agraria”, Białystok 2009, t. 7. 
Obok konkurencyjności rolnictwa ważnym elementem WPR, który stanowi o wielkości uzyskiwanej pomocy, jest polityka zazieleniania ${ }^{54}$ (greeningu) ${ }^{55}$. Polityka ta wprowadziła przede wszystkim zmiany w systemie dostępu do płatności bezpośrednich $^{56}$, wiążąc je silniej z wymogami środowiskowymi ${ }^{57}$. Polega ono na przedsięwzięciu przez rolnika szeroko rozumianych i opisanych w rozporządzeniach europejskich ${ }^{58}$ praktyk korzystnych dla klimatu. W zamian za to rolnik otrzymuje dodatkowe wsparcie w ramach tzw. płatności za zazielenienie.

Kluczowym elementem wsparcia stało się także rolnictwo ekologiczne ${ }^{59}$. Nastawione jest ono nie tylko na wysoki poziom bezpieczeństwa produktów rolnych i żywności ${ }^{60}$, lecz także oddziałuje na konkurencyjność rolnictwa poprzez wsparcie jakości produktów rolnych ${ }^{61}$. To nowe podejście wzrostu konkurencyjności poprzez inwestycję w podnoszenie jakości produktów staje się współczesnym wyznacznikiem przyszłości rolnictwa. Już obecnie większość dotacji, oprócz podstawowych wymogów zasad wzajemnej zgodności, premiuje wykorzystywanie instrumentów prawnych związanych z szeroko rozumianą ekologizacją produkcji rolnej62.

54 S. Lakner, J. Schmitt, S. Schüler, Y. Zinngrebe, Naturschutzpolitik in der Landwirtschaft: Erfahrungen aus der Umsetzung von Greening und der ökologischen Vorrangfäche 2015, Getynga 2016; J. Martinez, Das Greening der Gemeinsamen Agrarpolitik, „Natur und Recht“, 2013, nr 35; M.A. Król, A. Niewiadomski, Rodzinne gospodarstwa rolne $w$ systemie prawnym ochrony środowiska i zrównoważonego rozwoju, [w:] Ekonomiczne i prawne mechanizmy wspierania i ochrony rolnictwa rodzinnego, M. Podstawka (red.), Warszawa 2015, s. 240-255; A. Niewiadomski, The direct payments system in European and Polish agriculture with particular emphasis on the greening policy, „Studia Iuridica”, Warszawa 2016, t. 66, s. 287-300.

55 A. Niewiadomski, Prośrodowiskowe determinanty polskiej i europejskiej polityki rolnej, „Studia Iuridica Lublinensia”, 2017, t. 26, s. 271-286; D. Milanowska, Płatność za zazielenienie w nowym modelu dopłat bezpośrednich, „Studia Iuridica Agraria”, Białystok 2015, t. 13, s. 7-18.

56 W. Czubak, W. Poczta, A. Sadowski, Wplyw proponowanej reformy systemu dopłat bezpośrednich po 2013 roku na sytuacje polskiego rolnictwa, „Wieś i rolnictwo”, 2011, nr 4.

57 M.A. Król, Nowe rozwiąania prawne w zakresie platności w ramach systemów wsparcia bezpośredniego, „Studia Iuridica Agraria”, Białystok 2015, t. 13.

58 Rozporządzenie 1307/2013.

59 S. Prutis, Ochrona środowiska za pomoca instrumentów prawno-finansowych Wspólnej Polityki Rolnej, „Studia Iuridica Agraria”, Białystok 2015, t. 13, s. 39-64; M.A. Król, Koncepcja rolnictwa ekologicznego, [w:] Prawo rolne. Problemy teorii i praktyki, R. Budzinowski, A. Zieliński (red.), Kluczbork 2002; S. Prutis, Regulacje prawne produkcji ekologicznej w rolnictwie polskim, „Studia Iuridica Agraria", Białystok 2013, t. 11, s. 39-60; M. Korzycka-Iwanow, P. Wojciechowski, Żywność ekologiczna w prawie USA i Unii Europejskiej, „Studia Iuridica Agraria”, Białystok 2015, t. 13, s. $19-38$.

60 K. Leśkiewicz, System jakości produktów rolnictwa ekologicznego. Aspekty prawne, Poznań 2011.

61 P. Wojciechowski, Gospodarstwo rodzinne jako gospodarstwo ekologiczne w prawie polskim $i$ prawie UE, [w:] Prawne mechanizmy wspierania i ochrony rolnictwa rodzinnego $w$ Polsce $i$ innych państwach Unii Europejskiej, P. Litwiniuk (red.), Warszawa 2015, s. 117-140.

62 M.A. Król, Ocena modelu prawnej ochrony środowiska we Wspólnej Polityce Rolnej, „Studia Iuridica Lublinensia”, 2017, t. 26, s. 227-254. 
Nowe podejście było związane również ze zwiększeniem roli bioróżnorodności63 w procesie produkcji rolnej. Zróżnicowanie produkcji nie tylko ma korzystnie wpływać na zachowanie środowiska naturalnego, ale także na zwiększenie możliwości konkurencyjnych poprzez dywersyfikację ${ }^{64}$ produkcji. Wsparcie oferowane w PROW, poprzez kolejne działania zwiększające bioróżnorodność, jest jednym z podstawowych instrumentów prawnych aktualnej WPR, wpływającej na konkurencyjność rolnictwa. Niewątpliwe takie podejście jest związane ze wzrostem ryzyka w rolnictwie z powodu zmian klimatycznych i wahan rynkowych w rolnictwie ${ }^{65}$. Przykładem znaczenia tego problemu była susza w Polsce w 2018 r., w wyniku której rolnicy ponieśli dotkliwe straty. Przejawem zwiększonej troski o otoczenie naturalne rolnictwa jest znaczne rozszerzenie działań rolno-środowiskowo-klimatycznych ${ }^{66}$. Podkreślenie znaczenia ochrony klimatu ${ }^{67}$ jest kolejnym wyznacznikiem formułowania nowych instrumentów WPR, mających wpływać na konkurencyjność rolnictwa w kolejnych latach ${ }^{68}$. Jednocześnie tak rozumiane rolnictwo będzie sprzyjało realizacji innych celów UE w zakresie ochrony klimatu nie tylko w sektorze rolnym.

\subsection{Przyszłość Wspólnej Polityki Rolnej w aspekcie konkurencyjności rolnictwa po 2020 roku}

Ewolucja polityki rolnej w Europie będzie miała ciąg dalszy. Trwają obecnie intensywne prace nad kształtem budżetu oraz instrumentów prawych, które mają być wprowadzone w perspektywie 2021-2027. Dyskusję nad nowymi rozwiązaniami WPR rozpoczęto już w 2017 r. ${ }^{69}$ Przeprowadzono pierwszą formalną dyskusję Rady UE, gdzie zarysowano główne założenia rozwoju rolnictwa europej-

63 P. Gała, Problematyka bioróżnorodności w nowym PROW na lata 2014-2020, „Studia Iuridica Agraria”, Białystok 2015, t. 13, s. 165-178.

64 D. Łobos-Kotowska, M. Stańko, Dywersyfikacja działalności rolniczej jako instrument wspierania rozwoju gospodarstwa rodzinnego na przyktadzie agroturystyki, [w:] Prawne mechanizmy wspierania i ochrony rolnictwa rodzinnego w Polsce i innych państwach Unii Europejskiej, P. Litwiniuk (red.), Warszawa 2015, s. 393-406.

65 P. Litwiniuk, Prawna ochrona bioróżnorodności jako element polityki zrównoważonego rozwoju obszarów wiejskich, [w:] Prawne instrumenty ochrony środowiska, B. Jeżyńska, E. Kruk (red.), Lublin 2016, s. 313-326.

66 E. Nawrotek, Działanie rolno-środowiskowo-klimatyczne jako instrument ochrony środowiska w rolnictwie, [w:] Prawne instrumenty ochrony środowiska, B. Jeżyńska, E. Kruk (red.), Lublin 2016, s. 353-366.

67 M.A. Król, Rola gospodarstw rodzinnych w prawnej ochronie zasobów środowiska i różnorodności biologicznej, [w:] Prawne mechanizmy wspierania i ochrony rolnictwa rodzinnego $w$ Polsce i innych państwach Unii Europejskiej, P. Litwiniuk (red.), Warszawa 2015, s. 153-174.

68 W. Wigier, Wspólna Polityka Rolna po 2013 roku - zagadnienia wybrane, Warszawa 2013.

69 Szerzej na ten temat: A. Niewiadomska, Środowisko i konkurencja - Wspólna Polityka Rolna po $2020 r$., „Studia Iuridica”, 2018, t. 78. 
skiego ${ }^{70}$. Wskazano na konieczność uproszczenia WPR ${ }^{71}$. Postulat ten ma doprowadzić do wypracowania prostych instrumentów prawnych, które poza nowym otwarciem WPR ma ułatwić dostęp do funduszy europejskich dla większej liczby rolników.

W 2017 r. założono budowanie odporności, które wiązałoby się ze wspieraniem dochodów, wsparciem dla małych i średnich gospodarstw ${ }^{72}$. To podejście wyraźnie wskazuje na wsparcie zmierzające do zachowania konkurencyjności rolnictwa europejskiego, a nawet jego zwiększania ${ }^{73}$. Wzrost konkurencyjności ma następować przede wszystkim w sektorze gospodarstw małych i średnich. Zastosowanie do nich będą miały nie tylko instrumenty prawne WPR, ale także te, które oddziałują na obrót nieruchomościami rolnymi.

W dokumencie Rady z 2017 r. wskazano na konieczność reagowania na wyzwania środowiskowe. Reagowanie ma się odbywać „poprzez zwiększanie zrównoważonego charakteru rolnictwa, przeciwdziałanie zmianie klimatu, zapewnianie środowiskowych dóbr publicznych oraz wywiązywanie się ze zobowiązań międzynarodowych, zarówno tych, które dotyczą klimatu i które podjęto na konferencji UNFCCC COP 21, jak i tych, które dotyczą bardziej ogólnych celów przewidzianych w agendzie na rzecz zrównoważonego rozwoju 2030"74. Takie podejście powoduje postawienie w centralnym punkcie nowej legislacji rolnej wymogów środowiskowych oraz klimatycznych ${ }^{75}$. W zaprezentowanym stanowisku wypracowano także: zasadę inwestowania $\mathrm{w}$ rentowność i witalność obszarów wiejskich, zapewnienie wymiany pokoleniowej, zachowanie orientacji rynkowej, wzmacnianie pozycji rolników w łańcuchu żywnościowym, zarządzanie ryzykiem ${ }^{76}$, innowacje ${ }^{77}$; kwestie

$70 \mathrm{http}: / /$ data.consilium.europa.eu/doc/document/ST-6766-2017-INIT/PL/pdf [data dostępu 30 marca 2019 r.].

71 P. Litwiniuk, Uproszczenia Wspólnej Polityki Rolnej - nośny slogan czy absolutna konieczność?, „Studia Iuridica Agraria”, Białystok 2015, t. 13, s. 101-116.

72 D. Łobos, Model gospodarstwa rodzinnego w ustawodawstwie Wspólnot Europejskich oraz w ustawodawstwach narodowych państw członkowskich Wspólnot Europejskich, [w:] Prawo rolne u progu Unii Europejskiej, S. Prutis (red.), Białystok 1998, s. 267-272; T. Kurowska, Gospodarstwo rodzinne czy gospodarstwo rozwojowe. Dylematy wyboru, [w:] Prawo rolne u progu Unii Europejskiej, S. Prutis (red.), Białystok 1998, s. 109-118.

73 J. Sozański, Reformy Wspólnej Polityki Rolnej i prawa rolnego Unii Europejskiej po 1990 roku, „Ius Novum”, 2011, nr 1.

$74 \mathrm{http} / / /$ data.consilium.europa.eu/doc/document/ST-6766-2017-INIT/PL/pdf [data dostępu $30 \mathrm{mar}-$ ca 2019 r.].

75 W. Wołpiuk, Zasada zrównoważonego rozwoju. Zasada konstytucyjna czy zasada polityki spoteczno-ekonomicznej w zakresie ochrony środowiska, „Zeszyty Naukowe Wyższej Szkoły Informatyki, Zarządzania i Administracji w Warszawie, 2003, z. 1, s. 7-18; S. Kozłowski, Strategia zrównoważonego rozwoju Unii Europejskiej i jej implikacje dla Polski, „Biuletyn Polskiego Klubu Ekologicznego”, 2004.

76 I. Lipińska, Instrumenty ograniczania ryzyka produkcyjnego na rynku rolnym w aspekcie globalizacji - wybrane zagadnienia prawne i ekonomiczne, „Zeszyty Naukowe Szkoły Głównej Gospodarstwa Wiejskiego Problemy Rolnictwa Światowego", 2016, nr 31, s. 199-208.

77 J. Martinez, Chancen und Risiken der Digitalisierung in der Landwirtschaft - die rechtliche Dimension, „Przegląd Prawa Rolnego”, 2016, t. 19, nr 2, s. 13-44. 
proporcji między wsparciem bezpośrednim a rozwojem wsi. Wyzwaniem pozostaje wypracowanie konkretnych propozycji rozwiązań prawnych, które urzeczywistniłyby to podejście.

Kolejnym etapem w dyskusji nad przyszłością WPR było wydanie 29 listopada 2017 r. Komunikatu Komisji do Parlamentu Europejskiego, Rady, Europejskiego Komitetu Społeczno-Ekonomicznego i Komitetu Regionów - Przyszłość rolnictwa i produkcji żywności COM (2017) $713^{78}$. W komunikacie tym Komisja zaproponowała nowy model realizacji WPR, zgodnie z którym UE określa podstawowe parametry polityki, czyli cele, rodzaje interwencji i podstawowe wymagania, a państwa członkowskie opracowują strategiczne plany oparte o unijną strategię i przepisy w zakresie środowiska i klimatu. Takie podejście ma realizować jedne z głównych celów, jakim jest uproszczenie WPR.

Takie podejście jest nowością w spojrzeniu na WPR. Łamie ono dotychczasowe jednolite zasady planowania polityki rolnej na poziomie wspólnotowym na rzecz realizacji krajowych rozwiązań i strategii. Należy również zwrócić uwagę, że już w początkowych rozwiązaniach tego komunikatu zwrócono uwagę, że rozwiązania krajowe mają być zgodne ze strategiami i przepisami związanymi ze środowiskiem $\mathrm{i}$ klimatem. Ten dokument ponownie w centrum uwagi stawia przed rolnictwem europejskim nowe wyzwanie, jakim jest ochrona środowiska. Niewątpliwie przeniesienie ciężaru związanego z wyborem instrumentów WPR może okazać się ryzykowne ${ }^{79}$. W poszczególnych państwach będą obowiązywać zróżnicowane podejścia do finansowania rolnictwa, a co za tym idzie wzrost konkurencyjności w wybranych państwach może przyspieszyć albo spowolnić.

Przygotowane przez państwa członkowskie plany powinny obejmować interwencje w ramach obu filarów WPR, czyli wsparcie bezpośrednie i rozwój obszarów wiejskich ${ }^{80}$. Jak wskazano w komunikacie, zadaniem Komisji ma być ocena i zatwierdzanie planów strategicznych państw członkowskich. W planach tych państwa członkowskie powinny uwzględnić takie cele WPR, jak: wykorzystanie badań naukowych i innowacji; wspieranie inteligentnego i odpornego sektora rolnictwa; zwiększanie troski o środowisko i intensyfikacja działań w dziedzinie klimatu; umacnianie społeczno-gospodarczej struktury obszarów wiejskich; odpowiedź na obawy związane z bezpieczeństwem i jakością żywności; norm środowiskowych i odnoszących się do dobrostanu zwierząt. Konkurencyjność jest celem wynikającym z TFUE i nie została wprost wymieniona $\mathrm{w}$ tym dokumencie. Niewątpliwa troska o klimat jest wpisana

$78 \mathrm{https}: / /$ ec.europa.eu/agriculture/sites/agriculture/files/future-of-cap/future_of_food_and_farming communication_pl.pdf [data dostępu 30 marca 2019 r.].

79 M. Korzycka-Iwanow, Obszar ryzyka $w$ regulacjach prawa rolnego $i$ żywnościowego, „Studia Iuridica Agraria", Białystok 2001, t. 2.

80 A. Niewiadomska, Środowisko i konkurencja - Wspólna Polityka Rolna po 2020 r., „Studia Iuridica", 2018, t. 78. 
w szerszy kontekst globalnej polityki zmierzającej do ochrony niekorzystnych zjawisk klimatycznych ${ }^{81}$.

Dla realizacji zakładanych celów ważne są odpowiednie środki finansowe. 2 maja 2018 r. ukazał się Komunikat Komisji - Nowoczesny budżet dla Unii, która chroni, wspiera i broni Wieloletnie ramy finansowe na lata 2021-2027 COM (2018) $321^{82}$ oraz wniosek dotyczący Rozporządzenia Rady, określającego wieloletnie ramy finansowe na lata 2021-202783. Analiza tych dokumentów wskazuje, iż: zaplanowano obniżkę środków w programach wspólnej polityki rolnej; zwiększenie nacisku na problematykę środowiska ${ }^{84}$ i klimatu; zwiększenie poziomu współfinansowania krajowego w ramach rozwoju obszarów wiejskich; wprowadzenie nowego modelu realizacji polityki opartej na osiąganiu wspólnych celów, wyznaczonych na poziomie UE i wdrażanej w sposób elastyczny na szczeblu krajowym; skierowanie większych środków na pomoc dla małych i średnich gospodarstw na rozwój obszarów wiejskich; utworzenie nowej rezerwy kryzysowej. Połączono w tym zakresie dość ambitne cele $\mathrm{z}$ jednoczesnym obniżeniem poziomu finansowania europejskiego, zwiększonego zaangażowania środków krajowych.

Przedstawione propozycje mogą przynieść odwrotny efekt. Podniesienie wymogów środowiskowych i klimatycznych wraz ze zmniejszeniem wielkości środków pomocowych może zniechęcić rolników do sięgania po pomoc europejską i respektowania jej zasad. W zamian mogą zacząć realizować własne plany według zasad rolnictwa intensywnego. W krótkim okresie może przyczynić się to do podniesienia konkurencyjności, ale w dłuższej perspektywie może spowodować utratę zaufania konsumentów dla poszczególnych produktów rolnych. Zniweczy to nie tylko dotychczasowe zabiegi związane z realizowaną pomocą, ale przede wszystkim nie spowoduje osiągnięcia nowych celów WPR.

W nowej perspektywie budżetowej przewiduje się także możliwość zmniejszenia finansowania, jeżeli dane państwo członkowskie nie będzie przestrzegać zasad i reguł europejskich. W tym zakresie przygotowano wniosek dotyczący rozporządzenia Parlamentu Europejskiego i Rady w sprawie ochrony budżetu Unii w przypadku uogólnionych braków w zakresie praworządności w państwach członkowskich COM (2018) 32485.

${ }^{81}$ K. Błażejewska, Klimatyczne wyzwania Wspólnej Polityki Rolnej po 2013 r., „Przegląd Prawa Rolnego", 2011, nr 8, s. 135-158; M. Cardwell, European Union Agricultural Policy and Practice: The New Challenge of Climate Change, „Environmental Law Review”, 2011, nr 4, s. 271-295.

$82 \mathrm{https} / / /$ eur-lex.europa.eu/legal-content/PL/TXT/?qid=1526553268422\&uri=CELEX:52018DC0321 [data dostępu 30 marca 2019 r.].

83 https://eur-lex.europa.eu/legal-content/PL/TXT/?qid=1526550660947\&uri=CELEX:52018PC0322 [data dostępu 30 marca 2019 r.].

84 B. Jeżyńska, Funkcja środowiskowa gospodarstw rolnych, [w:] Prawne aspekty gospodarowania zasobami środowiska. Korzystanie z zasobów środowiska, B. Rakoczy, M. Szalewska, K. Karpus (red.), Toruń 2014, s. 70 i nast.

85 Zob. https://eur-lex.europa.eu/legal-content/PL/TXT/?qid=1526553554668\&uri=CELEX:52018 PC0324 [data dostępu 30 marca 2019 r.]. 
Regulacja ta w sposób szczególny może dotknąć Polskę, biorąc pod uwagę toczące się procedury przed organami Unii Europejskiej. Pozostaje oczywiście pytanie na ile tego typu dokumenty są polityczną grą, a na ile realnym zagrożeniem. Należy jednakże w najbliższej perspektywie uwzględnić ryzyko stosowania również takich zabiegów związanych z poziomem finansowania rolnictwa.

Założenia przyszłej WPR zaprezentowano także w drugiej połowie 2018 r., Parlament Europejski przyjął 30 maja 2018 r. rezolucję w sprawie przyszłości produkcji żywności i rolnictwa ${ }^{86}$. Parlament Europejski zajął w tym zakresie trzy podstawowe stanowiska.

Po pierwsze, dookreślił nowe stosunki między Unią Europejską, państwami członkowskimi, regionami i rolnikami. Na jednym z pierwszych miejsc tej rezolucji wysunięto znaczenie wzmacniania zrównoważonego zarządzania zasobami naturalnymi i przyczyniania się do osiągnięcia celów w zakresie środowiska i klimatu w ramach WPR. Samo umiejscowienie tego celu przed wszystkimi innymi wskazuje na nowy, jeszcze bardziej ,zielony” charakter polityki rolnej ${ }^{87}$. Producent rolny, chcący korzystać ze środków pomocowych z Unii Europejskiej, powinien przestrzegać wszelkich wspólnotowych wymogów środowiskowych ${ }^{88}$. Biorąc pod uwagę doświadczenia z realizacji perspektywy finansowej 2014-2020 oraz nastawienie rolników do polityki zazieleniania należy okazywać dużą ostrożność co do efektów zamierzonych celów. Rolnikom może się finansowo nie opłacać przestrzeganie zasad środowiskowych kosztem ewentualnej utraty dochodów. Ceny środowiska niestety nie da się określić. Jest ono dobrem niezbywalnym i często nieodtwarzalnym ${ }^{89}$. Niewątpliwie to podejście, zmierzające od odejścia od mechanizmów nastawionych na wsparcie finansowe w zamian z określoną ilość produkcji, może okazać się dużym wyzwaniem dla rolników. Producenci rolni mogą nie chcieć czekać na długofalową politykę proekologiczną. Będą może oczekiwali zysku zaraz po inwestycji. Jeżeli za nowymi wymogami nie zostaną przeznaczone odpowiednio wysokie środki finansowe, może okazać się, że WPR w obecnej formie nie będzie już tak atrakcyjna dla rolników.

Parlament $w$ rezolucji podkreślił potrzebę elastyczności w ramach WPR, ale jednocześnie odrzucił możliwość nacjonalizacji WPR, zachowując jednocześnie znaczną

$86 \mathrm{http}$ //www.europarl.europa.eu/sides/getDoc.do?pubRef=-//EP//TEXT+TA+P8-TA-20180224+0+DOC+XML+V0//PL\&language=PL [data dostępu 30 marca 2019 r.].

87 M.A. Król, Obszary o wysokich wartościach przyrodniczych i ich znaczenie w ochronie różnorodności biologicznej na obszarach wiejskich, [w:] Administracja publiczna a ochrona przyrody. Zagadnienia ekonomiczne, społeczne oraz prawne, M. Górski, D. Niedziółka, R. Stec, D. Strus (red.), Warszawa 2012, s. 47-66.

88 A. Niewiadomska, Środowisko i konkurencja - Wspólna Polityka Rolna po 2020 r., „Studia Iuridica", 2018, t. 78.

89 G. Anderson, J. Śleszyński, Ekonomiczna wycena środowiska przyrodniczego, [w:] Wartościowanie dóbr i zasobów środowiska, J. Śleszyński (red.), Białystok 1996; M.A. Król, K. Bańkowska, Wynagradzanie za środowiskowe dobra publiczne dostarczane przez rolnictwo, [w:] Dobra publiczne w administracji, M. Wożniak, M. Pierzchałka (red.), Warszawa 2014. 
elastyczność krajową w zakresie przygotowywanych planów strategicznych. Pozytywnie ocenił propozycję nowego modelu realizacji WPR, wskazując jednak, że będzie on przez kilka lat wymagał udoskonalania i zmian, tak aby rolnicy nie byli karani za przejście do nowego modelu. Zmiany te nie sprzyjają postulatowi uproszczenia WPR. Rolnicy, przyzwyczajeni do otrzymywania środków głównie na inwestycje i rozliczani ze wzrostu wartości swojego gospodarstwa, będą musieli w jeszcze większym stopniu przestrzegać zasad ochrony środowiska. W krótkiej perspektywie może się to wiązać dla nich z kosztami, a nie z dochodami. Może to także powodować obniżenie poziomu konkurencyjności nie tylko poszczególnych gospodarstw, ale całego sektora rolnego.

W rezolucji Parlament jednocześnie sprzeciwił się cięciom w budżecie na rozwój obszarów wiejskich, przewidzianych w proponowanych wieloletnich ramach finansowych (WRF). Stawia to pod znakiem zapytania wypracowanie przyszłego budżetu, który miałby rozwiązać problemy związane z zachęceniem rolników do realizacji nowych celów WPR. Pogodzenie ograniczenia finansowania WPR oraz nowych wyzwań stawianych przed rolnikami może być główną przeszkodą, w efektywnej realizacji zakładanych celów.

Po drugie, Parlament w rezolucji wskazał, że inteligentna, skuteczna, zrównoważona i sprawiedliwa WPR powinna służyć rolnikom, obywatelom, obszarom wiejskim i środowisku. W tej zbiorczej deklaracji podkreśla się występowanie innowacyjnego rozwoju oraz ochrony środowiska. Parlament domaga się utrzymania lub zwiększenia budżetu WPR w następnych WRF. W rezolucji podkreślono, że kryteria spójnościowe powinny nadal odgrywać ważną rolę w dystrybucji środków $\mathrm{z}$ drugiego filaru ${ }^{90}$. Ponadto, Parlament domaga się modernizacji obecnego systemu obliczania płatności bezpośrednich w pierwszym filarze. To ostatnie rozwiązanie jest wpisaniem się w trwającą od wielu lat dyskusję o przyszłości płatności bezpośrednich $^{91}$. Niektóre z prezentowanych koncepcji zakładają ich ujednolicenie, jeszcze inne ich zupełną likwidację. $\mathrm{Z}$ pewnością regulacje dotyczące płatności bezpośrednich - jako podstawowego mechanizmu wsparcia rolnictwa będą podlegały dalszej ewolucji. Pozostawienie jednakże określania szczegółowych wymogów państwom

90 B. Wieliczko, Czy warto stosować instrumenty finansowe w programach rozwoju obszarów wiejskich, „Zeszyty Naukowe SGGW w Warszawie. Problemy Rolnictwa Światowego”, 2016, t. 16, nr 1, s. $245-254$.

91 Z. Trojanowski, Prawne pojęcie producenta rolnego wedlug ustawy o krajowym systemie ewidencji producentów, ewidencji gospodarstw rolnych oraz ewidencji wniosków o przyznanie płatności w świetle orzecznictwa, „Przegląd Prawa Rolnego”, 2013, t. 12, nr 1, s. 85-100; J. Bieluk, D. ŁobosKotowska, Płatności bezpośrednie, [w:] Prawo rolne, P. Czechowski (red.), Warszawa 2015, s. 410-423; E. Kremer, Wybrane zagadnienia z problematyki rozwoju obszarów wiejskich, płatności bezpośrednich $w$ orzecznictwie sądów administracyjnych, „Studia Iuridica Agraria”, Białystok 2009, t. 7, s. 142-162; A. Germano, Reforma Wspólnej Polityki Rolnej z 2003 r. i reżim ptatności jednolitej, „Przegląd Prawa Rolnego", 2007, nr 1; T. Kurowska, Zadania i funkcje instrumentów prawnych wspierania rozwoju obszarów wiejskich, „Studia Iuridica Agraria”, Białystok 2005, t. 4. 
członkowskim uznaje się za wysoko dyskusyjne. Spowoduje to istnienie w najlepszym przypadku kilku, jeżeli nie ponad dwudziestu, różnych systemów wsparcia bezpośredniego.

Elementem próbującym pogodzić konkurencyjność rolnictwa oraz ochronę środowiska jest pkt 43 rezolucji, w którym wskazano, że „,dalsza liberalizacja rynku i związane z nią obniżenie ochrony rolników wiążą się z potrzebą rekompensaty dla sektora rolnictwa, a szczególnie dla tych gospodarstw rolnych, które znajdują się w niekorzystnej sytuacji z punktu widzenia konkurencji - przede wszystkim ze względu na trudności dotyczące użytkowania gruntów rolnych lub prowadzenia działalności na obszarach górskich - oraz że tylko takie środki kompensacyjne mogą zagwarantować ekstensywne gospodarowanie gruntami rolnymi i zachowanie krajobrazu kulturowego". Dotowanie obszarów o szczególnym znaczeniu przyrodniczym, aby podnosić ich konkurencyjność przy jednoczesnym zachowaniu ekstensywnego charakteru prowadzenia działalności rolniczej może się udać tylko w przypadku zachowania dość znacznego poziomu finansowania takiej działalności. Już obecnie płatności w ramach ONW wydają się nie rekompensować rolnikom prowadzącym tam działalność ponoszonych obciążeń i ograniczeń, wynikających z prawa własności nieruchomości. Brak odpowiedniego finansowania może spowodować, że gospodarstwa na tych terenach albo zbankrutują, albo będą musiały prowadzić działalność o charakterze intensywnym.

Jednocześnie w pkt 93 rezolucji Parlament „wzywa Komisję do dopilnowania, aby zapisane w drugim filarze działania rolno-środowiskowo-klimatyczne na rzecz rozwoju obszarów wiejskich rekompensowały dodatkowe koszty i uszczuplenie dochodów związane z dobrowolnym wdrażaniem przez rolników praktyk przyjaznych dla środowiska i klimatu oraz dawały możliwość dodawania zachęty do inwestowania w ochronę środowiska, różnorodność biologiczną i zasobooszczędność; uważa, że programy te powinny zostać uproszczone, lepiej ukierunkowane i być wydajniejsze, tak aby rolnicy mogli w sposób skuteczny wywiązywać się z ambitnych celów polityki w odniesieniu do ochrony środowiska, różnorodności biologicznej, gospodarki wodnej oraz działań w dziedzinie klimatu i łagodzenia zmian klimatu, przy jednoczesnym zapewnianiu minimalnego poziomu biurokracji na szczeblu gospodarstw oraz - przy uwzględnieniu warunków lokalnych - odpowiedniej kontroli ze strony państw członkowskich". Takie stanowisko oznacza konieczność znacznych preferencji dla działań o charakterze środowiskowym. Obecnie są one za niskie. Nie zachęcają rolników do prowadzenia działalności ekstensywnej i prośrodowiskowej. Parlament także, w przywołanym pkt 93 dostrzega dotychczasowy brak skuteczności realizacji celów WPR w zakresie ochrony środowiska.

Po trzecie, Parlament w rezolucji wskazał na silną pozycję rolników w globalnym systemie żywnościowym - w tym m.in. zwrócił się do KE o uznanie rolnictwa za działalność strategiczną w ramach negocjacji handlowych. Pozwala to na utrzymanie rolnictwa w głównym nurcie gospodarczym Unii Europejskiej. Wpisane jest także 
w negocjacje handlowe, które mają doprowadzić do zawarcia umów na wzór z Kanadą czy Japonią.

Dotychczasowym zwieńczeniem prac nad WPR po 2020 r. było przesłanie przez Komisję 1 czerwca 2018 r. trzech wniosków legislacyjnych z zakresu realizacji negocjowanych celów WPR.

Pierwszy z nich dotyczy wniosku o rozporządzenie Parlamentu Europejskiego i Rady ustanawiające przepisy dotyczące wsparcia na podstawie planów strategicznych sporządzanych przez państwa członkowskie w ramach wspólnej polityki rolnej (planów strategicznych WPR) i finansowanych z Europejskiego Funduszu Rolniczego Gwarancji (EFRG) i z Europejskiego Funduszu Rolnego na rzecz Rozwoju Obszarów Wiejskich (EFRROW) oraz uchylające rozporządzenie Parlamentu Europejskiego i Rady (UE) nr 1305/2013 i rozporządzenie Parlamentu Europejskiego i Rady (UE) nr 1307/201392. Wskazano w nim cele ogólne i szczegółowe WPR. Zaliczono do nich w art. 6 ust. 1 projektowanego rozporządzenia przede wszystkim: wspieranie godziwych dochodów gospodarstw rolnych i odporności w całej Unii (w celu wzmocnienia bezpieczeństwa żywnościowego); zwiększenie zorientowania na rynek i konkurencyjności, w tym większe ukierunkowanie na badania naukowe, technologię i cyfryzację; poprawę pozycji rolników w łańcuchu wartości. W aspekcie środowiskowym przyczynianie się do łagodzenia zmiany klimatu i przystosowywania się do niej, a także wykorzystanie zrównoważonej energii; wspieranie zrównoważonego rozwoju i wydajnego gospodarowania zasobami naturalnymi, takimi jak woda, gleba i powietrze. Takie działania mają przyczyniać się do ochrony różnorodności biologicznej, wzmacniania usług ekosystemowych oraz ochrony siedlisk i krajobrazu. Ponadto, ma zostać zintensyfikowane przyciąganie młodych rolników i ułatwianie rozwoju działalności gospodarczej na obszarach wiejskich; promowanie zatrudnienia, wzrostu, włączenia społecznego i rozwoju lokalnego na obszarach wiejskich, w tym biogospodarki i zrównoważonego leśnictwa. Poprawy wymaga również stopień reakcji rolnictwa UE na potrzeby społeczne dotyczące żywności i zdrowia, w tym bezpiecznej, bogatej w składniki odżywcze i zrównoważonej żywności, jak też dobrostanu zwierząt.

Każdy z określonych powyżej w projekcie rozporządzenia celów WPR po $2020 \mathrm{r}$. dotyczy ochrony środowiska, klimatu i bioróżnorodności. Konkurencyjność i dochodowość rolnictwa w tym zakresie jest traktowana na równi z tymi celami, a nie jak dotychczas priorytetowo. Nowe zorientowanie WPR na „zielone rolnictwo” może przynieść dość nieoczekiwany efekt ekonomiczny, z uwagi na koszt produkcji produktów ekologicznych.

W projektowanym rozporządzeniu określono wymogi odnoszące się do planów strategicznych i interwencji państw członkowskich, alokacji środków finansowych w podziale na państwa członkowskie i fundusze oraz określono stopień elastyczności

92 Zob. https://eur-lex.europa.eu/legal-content/PL/TXT/?uri=CELEX:52018PC0392\&qid=1528452 097687 [data dostępu 30 marca 2019 r.]. 
dozwolony przy przesunięciach środków między funduszami. Wskazano na nowe zasady opracowywania i zmiany planów strategicznych oraz ich zatwierdzania przez Komisję, zasady dotyczące koordynacji i zarządzania, ramy realizacji, monitorowania i ewaluacji. Te bardzo techniczne rozwiązania w dużej mierze przesuwają realizację i określanie szczegółowych zadań WPR na państwa członkowskie, którym w przyszłej perspektywie finansowej pozostawia się dość dużą dowolność. Pozwala to nie tylko dość swobodnie kształtować poszczególne instrumenty prawne państwom członkowskim, ale przede wszystkim stwarza zagrożenie dla określenia zróżnicowania na rynku europejskim. Takie podejście może znacząco wpłynąć na konkurencyjność poszczególnych produktów na rynku europejskim.

Drugi z przesłanych przez Komisję projektów dotyczy rozporządzenia Parlamentu Europejskiego i Rady w sprawie finansowania wspólnej polityki rolnej, zarządzania nią i monitorowania jej oraz uchylające rozporządzenie (UE) nr 1306/201393. Dostosowano w nim przepisy horyzontalne do nowego modelu realizacji polityki. Określono zasady finansowania różnych interwencji i środków wchodzących w zakres WPR z budżetu ogólnego Unii, które odbywa się poprzez: Europejski Fundusz Rolniczy Gwarancji (EFRG) oraz Europejski Fundusz Rolny na rzecz Rozwoju Obszarów Wiejskich (EFRROW).

Trzecim przesłanym przez Komisję projektem jest rozporządzenie Parlamentu Europejskiego i Rady zmieniające rozporządzenia: (UE) nr 1308/2013 ustanawiające wspólną organizację rynków produktów rolnych, (UE) nr 1151/2012 w sprawie systemów jakości produktów rolnych i środków spożywczych, (UE) nr 251/2014 w sprawie definicji, opisu, prezentacji, etykietowania i ochrony oznaczeń geograficznych aromatyzowanych produktów sektora wina, (UE) nr 228/2013 ustanawiające szczególne środki w dziedzinie rolnictwa na rzecz regionów najbardziej oddalonych w Unii Europejskiej i (UE) nr 229/2013 ustanawiające szczególne środki dotyczące rolnictwa dla mniejszych wysp Morza Egejskiego ${ }^{94}$. Przewidziano w nim uchylenie przepisów dotyczących interwencji sektorowych, które zostaną uregulowane rozporządzeniem dotyczącym planu strategicznego WPR i będą częścią planów strategicznych państw członkowskich. Oznacza to odejście od dotychczasowego podejścia horyzontalnego do rynków rolnych i przeniesienie interwencji do państw członkowskich. Zmiana tej polityki kształtowanej od 2007 r. jest powrotem do sektorowej regulacji rynków rolnych. Pozostawienie kształtowania mechanizmów prawnych WPR w większej części w gestii państw członkowskich może okazać się zabiegiem ryzykownym. W projekcie rozporządzenia przewidziano także zmiany w przepisach dotyczących rynku wina, zmiany w przepisach dotyczących oznaczeń geograficznych.

93 Zob. https://eur-lex.europa.eu/legal-content/PL/TXT/?uri=CELEX:52018PC0393\&qid=1528452 398071 [data dostępu 30 marca 2019 r.].

94 Zob. https://eur-lex.europa.eu/legal-content/PL/TXT/?uri=CELEX:52018PC0394\&qid=1528452 463620 [data dostępu 30 marca 2019 r.]. 
Zaprezentowane projekty rozporządzeń spotkały się ze stanowiskiem polskiego rządu z sierpnia 2018 r. ${ }^{95}$. Polska przede wszystkim opowiada się przeciwko zmniejszeniu finansowania WPR. Stanowisko to należy poprzeć. Zaprezentowane przyszłe instrumenty prawne WPR wymuszają na rolnikach zmianę sposobu produkcji i inwestycje w nowe technologie. Bez odpowiedniego finansowania ze środków europejskich cele te nie będą mogły być zrealizowane. Zwiększenie budżetu na sektor rolny wydaje się obecnie mało realne. Budzi to istotne obawy czy wypracowywane instrumenty prawne będą mogły być skuteczne, bez odpowiednio wysokiego poziomu finansowania.

Polska w stanowisku swojego rządu przeciwstawia się także zwiększeniu zaangażowania krajowego w politykę rozwoju obszarów wiejskich, zwracając uwagę, że mniej zamożne państwa nie będą w stanie uczestniczyć w niej na takim samym poziomie, co zaburzy konkurencyjność na rynku europejskim. Podkreślane jest to przede wszystkim w związku z nasileniem celów prośrodowiskowych. Polska przedstawia stanowisko, iż wymagają one podnoszenia nakładów budżetowych. Zwiększenie finansowania polityki rolnej poprzez państwa członkowskie może sprzyjać utracie podstawowych instrumentów wpływających na konkurencyjność. Państwa uboższe będą miały inne priorytety budżetowe niż rolnictwo.

Rząd polski zwraca również uwagę na kwestię wyrównywania płatności bezpośrednich w różnych państwach członkowskich. Postulat ten prezentowany ponownie w kolejnej debacie nad przyszłością WPR - nadal nie znajduje szerszego zrozumienia. Zróżnicowane tempo dochodzenia do jednolitej wielkości płatności istotnie zaburzy reguły konkurencji na wspólnym europejskim rynku. W tym zakresie wiele kontrowersji budzą tzw. ekoprogramy, jako element dotychczasowego wsparcia w ramach płatności bezpośrednich.

W cytowanym stanowisku rządu zawarto jeszcze wiele szczegółowych uwag, które wykraczają poza ramy aktualnego opracowania. Należy podkreślić, że większość tych uwag wydaje się być zasadną, w szczególności jeżeli weźmiemy pod uwagę czas, jaki pozostał na wdrożenie nowej polityki rolnej oraz zmniejszone finansowanie.

\subsection{Podsumowanie}

Przedstawiona analiza ewolucji instrumentów prawnych WPR wpływających na konkurencyjność rolnictwa pozwala wysnuć kilka wniosków. Już historycznoprawna ocena zaprezentowanych mechanizmów prawnych wskazuje na niejednorodność w interpretacji traktatowych celów WPR. Treść tych ostatnich nie uległa większym

95 Zob. https://www.gov.pl/documents/912055/913531/Za\%C5\%826_Stanowisko_RP_dot_pakietu_ WPR_po_2020_roku_-_COM\%282018\%29_392_393_394.pdf/cd795 bba-aabf-6b 2a-2c9e-f6d8dc $51826 \mathrm{c}$ [data dostępu 30 marca 2019 r.]. 
zmianom od 1957 r. Natomiast od Traktatów Rzymskich można zaobserwować dostosowywanie w zależności od efektów ekonomicznych poszczególnych instrumentów prawnych do zmieniającego się otoczenia sektora rolnego. Prawo służyło w tym zakresie realizacji celów ekonomicznych ${ }^{96}$. Kiedy regulacje prawne okazywały się nieskuteczne w kolejnym okresie programowania przestawały istnieć, bądź istotnie je zmieniano.

W ostatnich prawie siedemdziesięciu latach funkcjonowania WPR można zaobserwować wiele instrumentów o charakterze interwencyjnym. Łączy ich jedna wspólna cecha - ingerencji w wolny rynek. Różni - intensywność nasilenia stopnia ingerencji oraz ocena oczekiwanych efektów. Przejście od silnego protekcjonizmu, poprzez stopniową liberalizację, po wypracowanie mechanizmów środowiskowych i klimatycznych wpływało na poziom konkurencyjności rolnictwa.

Pierwotnie instrumenty prawne miały wspierać dochody rolnicze oraz produkcję. Następnie dotowano ograniczanie produkcji poprzez systemy kwotowania, w celu zachowania płynności niektórych rynków rolnych. Obecnie można zaobserwować próbę wypracowania takich mechanizmów prawnych, które będą wpływały nie tylko na rolnictwo, ale także poprzez swoje ekologiczne aspekty, będą oddziaływały na inne sektory. Dlatego też analiza mechanizmów prawnych w zakresie polityki zazieleniania, czy bioróżnorodności musi być rozpatrywana w szerszym kontekście. Oczywiście, będzie ona wpływać na konkurencyjność samego rolnictwa, przede wszystkim poprzez podniesienie jakości produktów, ale także powinna wywrzeć odpowiednie skutki w pozostałych sektorach gospodarki.

Analiza współczesnych instrumentów WPR w oderwaniu od stanu całej gospodarki i jej otoczenia wydaje się niezwykle utrudniona. Wymagania stawiane rolnikom oddziałują na funkcjonowanie ochrony przyrody w szerszym spektrum. Niewątpliwie również przesunięcie instrumentów prawnych WPR w kierunku działań środowiskowo-klimatycznych utrudnia analizy ekonomiczne umożliwiające rzetelną ocenę poziomu konkurencyjności. Trudno jest wycenić wartość ochrony środowiska naturalnego w procesie produkcji rolnej. Trzeba także przedsięwziąć działania informacyjne konsumentów o pochodzeniu danego produktu i stosowanych metodach produkcji. Konsument, mając do wyboru tańszy produkt wyprodukowany metodami prawie przemysłowymi i droższy pochodzący od rolników, którzy przestrzegają zasad ochrony środowiska, może kierować się w swoim wyborze kryterium ceny.

Powstaje pytanie: dokąd zmierza ewolucja instrumentów WPR, które wpływają na konkurencyjność rolnictwa? Które elementy systemu europejskiej polityki rolnej odegrają ważną rolę w kształtowaniu rolnictwa w UE? Proponowane reformy pogłębiają nacisk nie na ilość produktów rolnych, ale na ich jakość, na zapewnienie ich bezpieczeństwa. Służy temu preferowanie produkcji ekologicznej, czy też takiej,

96 J. Goździewicz-Biechońska, The role of agriculture in circular economy (legal per-spective), „Przegląd Prawa Rolnego”, 2016, t. 18, nr 1. 
w której będą przestrzegane zasady ochrony środowiska. Jakość i bezpieczeństwo produktów rolnych stają się jednym z ważniejszych wyznaczników konkurencyjności rolnictwa.

Przedstawione $\mathrm{w}$ ostatnim podrozdziale analizy, związane $\mathrm{z}$ dwoma elementami nowej WPR - środowiskiem i konkurencyjnością, są tylko częścią największej pod względem legislacyjnym i budżetowym europejskiej polityki. W każdym okresie programowania wyznaczanym przez ramy budżetowe w odmienny sposób kształtowano szczegółowe instrumenty ${ }^{97}$ ingerencji, tudzież pomocy dla rolników. Aktualne propozycje odchodzą od wspierania tylko rolnika, na rzecz dbania o dobro ogółu. Centralnym dobrem chronionym ma być nie tylko rolnik i jego działalność, lecz także środowisko i klimat.

Próba wyważenia pomiędzy interesami rolnika, który chce zwiększać dochodowość i konkurencyjność swojego gospodarstwa, a ochroną środowiska jest zadaniem trudnym. Staje się ono prawie niewykonalne, jeżeli weźmiemy pod uwagę realną groźbę istotnego zmniejszenia finansowania WPR ze środków europejskich i zwiększenie udziału środków krajowych. Może się okazać, że w rachunku ekonomicznym proponowane rozwiązania prawne w zakresie WPR nie będą zachęcać rolników do korzystania $\mathrm{z}$ tej formy wsparcia. Wtedy instrumenty prawne WPR, wpływające na konkurencyjność, mogą nie znajdować zastosowania, bo rolnicy nie będą zainteresowani ich wykorzystaniem. Dla nich może być bardziej opłacalnym prowadzenie rolnictwa intensywnego, nastawionego na wielkość produkcji, a nie wdrażającego ekoprogramy ${ }^{98}$ i wprowadzającego na rynek produkty, którymi będzie interesować się wąska grupa konsumentów.

Zidentyfikowane zagrożenia, wynikające z relacji środowiska i konkurencyjności rolnictwa, należy już obecnie zminimalizować. Najprostszym sposobem będzie oczywiście zwiększenie w budżecie zachęt finansowych dla rolników. Odpowiedni system kompensacji w zamian za wdrażanie praktyk korzystnych dla klimatu ${ }^{99}$ i środowiska może okazać się kluczem do sukcesu WPR. Poza tym równie ważnym elementem jest edukacja zarówno rolników, jak i konsumentów z zakresu korzyści płynących $\mathrm{z}$ ochrony bioróżnorodności $\mathrm{w}$ procesie produkcji rolnej. Bez tych dwóch podstawowych elementów nawet najlepiej opisane mechanizmy WPR mogą okazać się nieskuteczne.

97 S. Prutis, Instrumenty prawne wsparcia rozwoju rolnictwa ze środków UE (w świetle orzecznictwa Wojewódzkiego Sądu Administracyjnego w Białymstoku), „Studia Iuridica Agraria”, Białystok 2007, t. 6.

98 J. Goździewicz-Biechońska, Nowe paradygmaty ochrony ziemi jako zasobu środowiska w prawie rolnym, „Przegląd Prawa Rolnego”, 2017, t. 21, nr 2, s. 77-92.

99 P. Sulewski, S. Czekaj, Zmiany klimatyczne oraz instytucjonalne a przewidywane wyniki ekonomiczne gospodarstw, „Zagadnienia Ekonomiki Rolnej” 2015, nr 1; Climate Change and Agriculture in the United States: Effects and Adaptation, C.L. Walthall (red.), „USDA Technical Bulletin”, 2012, nr 193. 
Jednocześnie powyższa analiza wykazała, że uproszczenie WPR może nie być łatwym i szybkim procesem. Planowane przeniesienie dużej części regulacji na poziom krajowy nie uprości stosowanych procedur pomocowych, a właściwy dobór instrumentów prawnych wydaje się kluczowym zagadnieniem ${ }^{100}$. Skutek będzie prawdopodobnie przeciwny. Aktualne regulacje związane z warunkami koniecznymi do ubiegania się o pomoc oraz stosowane do nich procedury istotnie zniechęcają ${ }^{101}$ rolników do korzystania ze środków finansowych. Należy postulować nie tylko w sferze ideologii o ich uproszczenie, ale o stworzenie realnej pomocy dla rolników. Można w tym zakresie wykorzystać chociażby program doradztwa rolniczego ${ }^{102}$.

100 S. Prutis, Dobór instrumentów prawnych stużących wsparciu rozwoju obszarów wiejskich, „Studia Iuridica Agraria”, Białystok 2009, t. 7, s. 192-203.

101 W. Czubak, A. Sadowski, Dostępność informacji oraz czynniki utrudniające ubieganie się o doplaty bezpośrednie, „Wieś i Rolnictwo”, 2010, nr 3.

102 M.A. Król, Model doradztwa rolniczego $w$ Polsce na tle rozwiąań przyjętych $w$ wybranych krajach członkowskich Unii Europejskiej, Warszawa 2013. 


\section{Rozdział 3}

\section{Podstawy prawne rozdysponowywania funduszy europejskich wpływających na konkurencyjność rolnictwa}

Ewolucja Wspólnej Polityki Rolnej postępowała nie tylko wraz z kolejnymi pomysłami politycznymi, lecz przede wszystkim obejmowała liczne zmiany prawa. Polegały one na wydawaniu w każdym okresie finansowania nowych rozporządzeń europejskich oraz pewnych aktów o charakterze soft law (takich jak wytyczne, rezolucje, komunikaty). Niezmiennym w tym zakresie pozostawały tylko regulacje traktatowe w odniesieniu do zakładanych celów WPR.

Za zmianami unormowań europejskich szły nowe regulacje krajowe. W Polsce przekładały się one na nowe ustawy lub ich nowelizacje. Każde z działań PROW wymagało co najmniej jednego rozporządzenia wykonawczego. Do tego dochodziły różnego typu formularze, instrukcje oraz standardy postępowań. Kontrowersyjną sprawą w polskiej nauce prawa jest także status prawny PROW, który nie jest aktem prawa powszechnie obowiązującego, ale wywołuje skutki prawne1.

Liczne zmiany prawne nie sprzyjały pewności prawa oraz bezpieczeństwu obrotu. Niejednokrotnie też zachęcając do pozyskiwania pomocy ingerowały w prawa podmiotowe, jak chociażby prawo własności nieruchomości przy kolejnych wymogach, związanych $\mathrm{z}$ dostępem do płatności bezpośrednich. Niewątpliwie już na tym etapie należy wyrazić postulat wskazujący na konieczność ujednolicenia stosowanych procedur oraz pozostawiania instrumentów prawnych, które się sprawdzily w dość stałej formie.

Wyzwaniem staje się również nowe podejście do wprowadzania instrumentów WPR wpływających na konkurencyjność po 2020 roku. Zaprezentowana w poprzednim rozdziale informacja o aktualnym stanie prac nad reformą WPR, jako jeden $\mathrm{z}$ ważnych czynników wskazała wzrost znaczenia legislacji krajowej w przyszłej perspektywie. Regulacje rolne wkroczą w nową fazę, gdzie od postanowień unormowań państwa członkowskiego będą zależały szczegółowe warunki i kryteria udzielania pomocy.

Podjęta w tym rozdziale analiza ma również wykazać, że na konkurencyjność rolnictwa składa się obecnie szereg unormowań. Ostateczna ocena ekonomicznych efektów nie zależy tylko od jednego aktu prawnego, ale od całego systemu regulacji. To,

1 P. Litwiniuk, Program Rozwoju Obszarów Wiejskich jako dokument programowy i źródło prawa rolnego, Warszawa 2018. 
czy przykładowo działania związane ze wsparciem młodych rolników się sprawdzą, będzie zależało także od dostępności ziemi dla młodych rolników. Dopiero oceniając całokształt unormowań można dokonać oceny, czy służą one wzrostowi konkurencyjności. Zaprezentowane akty prawne dotyczą tylko okresu programowania 2014-2020, chociaż niektóre z nich odnoszą się także do lat 2007-2013. Czasami w kilku miejscach dokonano analizy historycznoprawnej, aby ukazać ewolucję niektórych aktów prawnych.

\subsection{Regulacje europejskie dotyczące konkurencyjności rolnictwa}

Na poziomie europejskim największe znaczenie ma TFUE. Z niego wynikają główne zasady związane $\mathrm{z}$ funkcjonowaniem nie tylko całej UE, lecz także rolnictwa. Ponadto, istnieją regulacje związane z konkurencyjnością rolnictwa w zakresie wykonywania poszczególnych zadań związanych z instrumentami prawnymi WPR. Zaprezentowane poniżej rozporządzenia dotyczą przede wszystkim funkcjonowania funduszy europejskich. Nie należy jednak zapominać o rozporządzeniach pośrednio związanych z unormowaniami rolnymi.

Osobnym katalogiem aktów prawnych są akta o charakterze soft law. Dotyczą one nie tylko wytycznych, czy zaleceń związanych z podziałem środków europejskich, lecz coraz częściej zaczynają pośrednio oddziaływać na regulacje krajowe. Dużego znaczenia $\mathrm{w}$ ostatnim okresie nabierają akty prawne związane $\mathrm{z}$ funkcjonowaniem rynku ziemi oraz obrotu nieruchomościami rolnymi. Kształt tego obrotu, a także instrumenty prawne tam stosowane w sposób bezpośredni wpływają na warsztat pracy rolnika, a co za tym idzie na poziom konkurencyjności.

\subsubsection{Podstawy traktatowe}

Podstawowym przepisem dla określania instrumentów wpływających na konkurencyjność rolnictwa jest art. 39 ust. 1 lit. a Traktatu o funkcjonowaniu Unii Europejskiej². W tym przepisie wskazano, że celem WPR jest „zwiększenie wydajności rolnictwa przez wspieranie postępu technicznego, racjonalny rozwój produkcji rolnej, jak również optymalne wykorzystanie czynników produkcji, zwłaszcza siły roboczej"3. Do tak określonego celu przez kolejne dziesięciolecia poszukiwano właściwych instrumentów prawnych dla podniesienia konkurencyjności rolnictwa.

Niewątpliwie pozostałe cele $\mathrm{WPR}^{4}$ wymienione w art. 39 TFUE również oddziałują na określanie instrumentów prawnych w ramach finansowania polityki rolnej.

2 A. Jurcewicz, Traktatowe podstawy unijnego prawa rolnego w świetle orzecznictwa. Zagadnienia wybrane, Warszawa 2012.

3 Traktat o funkcjonowaniu Unii Europejskiej (Dz. U. z 2004 r. poz. 864 z późn. zm.).

4 Przywołano je w poprzednim rozdziale. 
Stanowią one w tym zakresie połączony ze sobą mechanizm celów, które jako całość mają za zadanie poprawić sytuację ekonomiczną rolnika.

W Traktacie można również odnaleźć przepisy, chociażby pośrednio nawiązujące do organizacji rynków rolnych, czy też reguły konkurencji ${ }^{5}$. Tylko dla przykładu można wskazać art. 40 ust. 1 TFUE stanowiący, że na wspólnym rynku produktów rolnych obowiązują wspólne reguły konkurencji; obowiązkowa koordynacja różnych krajowych organizacji rynkowych; czy europejska organizacja rynkowa ${ }^{6}$. W następnym ustępie tego przepisu wskazuje się na możliwe instrumenty prawne, które mają urzeczywistnić wspólne reguły konkurencji. Do tych instrumentów w art. 40 ust. 2 TFUE zaliczono: regulację cen, subwencje służące produkcji i wprowadzaniu na rynek różnych produktów, systemy magazynowania i przewozu oraz wspólne mechanizmy stabilizacji przywozu i wywozu?

Tego typu rozwiązania są tylko przykładem na to, że na konkurencyjność w rolnictwie nie wpływa tylko jeden pojedynczy instrument prawny. Muszą zaistnieć odpowiednie systemy tych instrumentów, które będą na siebie wzajemnie oddziaływały i uzupełniały się. Dopiero wówczas nastąpi oczekiwany przez deklarowane cele WPR wzrost konkurencyjności. Ocenianie skuteczności danego instrumentu tylko poprzez pryzmat jego efektywności może okazać się kontrproduktywne. Rolnictwo w tym zakresie powinno stać się wielofunkcyjne 8 .

Innym przykładem regulacji traktatowych wpływających na konkurencyjność rolnictwa jest art. 42 TFUE. Ustanawia on szczególne reguły konkurencji na rynku rolnym i umożliwia wyłączenie ogólnych zasad ${ }^{9}$. Jest to odstępstwo od ogólnych reguł konkurencji ${ }^{10}$. W szczególnych przypadkach, zgodnie z tym przepisem, Rada, na wniosek Komisji, może zezwolić na przyznanie pomocy: na ochronę gospodarstw znajdujących się w niekorzystnym położeniu ze względu na warunki strukturalne lub przyrodnicze; w ramach programów rozwoju gospodarczego ${ }^{11}$. Oznacza to normatywne usankcjonowanie możliwości ingerencji w system wolnego rynku. Pozwala zatem

5 P. Czechowski, A. Niewiadomski, Tendencje rozwoju polskiego prawa rolnego $w$ zwiąku z nabyciem czlonkostwa Polski w Unii Europejskiej, „Studia Iuridica Agraria”, Białystok 2009, t. 7, s. 30-45.

6 P. Czechowski, Proces dostosowywania polskiego prawa rolnego i żywnościowego do prawa Unii Europejskiej, Warszawa 2001

7 Prawo i polityka rolna Unii Europejskiej, A. Jurcewicz (red.), Warszawa 2010.

8 J. Mikołajczyk, Współczesne funkcje obszarów wiejskich na tle koncepcji multifunkcjonalnego rolnictwa, „Studia Iuridica Agraria”, Białystok 2012, t. 10, s. 367-384.

9 Wyrok Trybunału z dnia 15 listopada 1979 r. w sprawie 36/79, Denkavit Futtermittel GmbH v. Finanzamt Warendorf, ECR 1979, s. 03439.

10 P. Czechowski, Reguły konkurencji oraz pomoc publiczna w rolnictwie, Warszawa 2001; A. Jurkowska-Gomułka, T. Skoczny, Wspólne reguły konkurencji Unii Europejskiej. System Prawa Unii Europejskiej, J. Barcz (red.), t. XXIV, Warszawa 2010; S. Emmis, Competition and Regulation in Agriculture, OECD ,Journal of Competition Law and Policy”, 2007, t. 9, nr 2, s. 93 i nast.

11 Wyrok Trybunału z dnia 16 grudnia $1975 \mathrm{r}$. w połączonych sprawach $\mathrm{nr} 40-48,50,54-56,111,113$ i 114/73, Coöperatieve Vereniging „Suiker Unie” UA and others v. Commission, ECR 1975, s. 01663. 
na pomoc publiczną, która będzie możliwa po spełnieniu odpowiednich wymogów proceduralnych i faktycznych ${ }^{12}$.

Konkurencji dotyczy także art. 44 i omawiana w poprzednim rozdziale opłata wyrównawcza ${ }^{13}$. Stosuje się ją wtedy, kiedy w państwie członkowskim produkt jest przedmiotem krajowej organizacji rynkowej lub regulacji wewnętrznej o skutku równoważnym, która wpływa na pozycję konkurencyjną produktu podobnego w innym państwie członkowskim. Wtedy państwa członkowskie stosują w przywozie opłatę wyrównawczą na taki produkt pochodzący z państwa członkowskiego, w którym istnieje taka organizacja lub regulacja, chyba że państwo to stosuje opłatę wyrównawczą przy wywozie.

Przywołane regulacje traktatowe są tylko przykładem na oddziaływanie unormowań na poziomie najwyższego aktu prawnego na konkurencyjność rolnictwa. Szczegółowa analiza innych przepisów TFUE, znacznie wykraczająca poza ramy tego rozdziału, byłaby potwierdzeniem tezy o funkcjonowaniu systemu przepisów wpływających na konkurencyjność rolnictwa.

Oczywistym jest również, że regulacje traktatowe stanowią bezpośrednią podstawę prawną do wydawania wszystkich pozostałych aktów prawnych, czyli rozporządzeń, dyrektyw oraz aktów prawnych o charakterze soft law.

\subsubsection{Rozporządzenia europejskie}

Do rozporządzeń europejskich oddziałujących na konkurencyjność rolnictwa można zaliczyć akty prawne o charakterze bardzo ogólnym dotyczącym przykładowo budżetu, czy finansowania WPR. Najważniejsze instrumenty prawne wpływające na konkurencyjność rolnictwa unormowane są jednakże w rozporządzeniach szczegółowych, takich jak o działaniu funduszy rolnych, czy organizacji rynku rolnego.

Można zaobserwować, że rozporządzenia szczegółowe są zmieniane na nowe z każdym kolejnym okresem programowania. Oznacza to z punktu widzenia legislacyjnego rozpisywanie i kształtowanie instrumentów prawnych od nowa. Umożliwia to ich ewolucję i dostosowanie do aktualnych warunków ekonomicznych.

Poniżej omówione rozporządzenia są tylko wybranymi aktami prawnymi z uwagi na cele rozprawy. Nie wyczerpują całości przeglądu rozporządzeń, które w sposób pośredni lub bezpośredni wpływają na wzrost konkurencyjności rolnictwa. Zasygnalizowano również najważniejsze rozporządzenia wykonawcze ${ }^{14}$ i delegowane.

12 Wyrok z dnia 13 października 1982 r. w połączonych sprawach 213-215/81, Norddeutsches Vieh- und Fleischkontor Herbert Will, Trawako, Transit-Warenhandels-Kontor GmbH \& Co., i Gedelfi, Großeinkauf GmbH \& Co., v. Bundesanstalt für landwirtschaftliche Marktordnung, ECR 1982, s. 03583.

13 M. Szydło, Konkurencja regulacyjna w prawie spółek, Warszawa 2008.

14 M. Żabicka-Kłopotek, Rozporządzenie wykonawcze jako element systemu źródel prawa powszechnie obowiazującego. Wybrane zagadnienia, ,Przegląd Legislacyjny”, 2011, nr 2-4 (76-78). 


\subsubsection{Rozporządzenie $1303 / 2013$}

Jednym z podstawowych aktów prawnych jest rozporządzenie Parlamentu Europejskiego i Rady (UE) nr 1303/2013 z dnia 17 grudnia 2013 r. ustanawiające wspólne przepisy dotyczące Europejskiego Funduszu Rozwoju Regionalnego, Europejskiego Funduszu Społecznego, Funduszu Spójności, Europejskiego Funduszu Rolnego na rzecz Rozwoju Obszarów Wiejskich oraz Europejskiego Funduszu Morskiego i Rybackiego oraz ustanawiające przepisy ogólne dotyczące Europejskiego Funduszu Rozwoju Regionalnego, Europejskiego Funduszu Społecznego, Funduszu Spójności i Europejskiego Funduszu Morskiego i Rybackiego oraz uchylające rozporządzenie Rady (WE) nr 1083/200615.

Jak wskazano w tytule tego aktu prawnego, rozporządzenie zgodnie $\mathrm{z}$ art. 1 ustanawia wspólne zasady, mające zastosowanie do: Europejskiego Funduszu Rozwoju Regionalnego (EFRR), Europejskiego Funduszu Społecznego (EFS), Funduszu Spójności, Europejskiego Funduszu Rolnego na rzecz Rozwoju Obszarów Wiejskich (EFRROW) oraz Europejskiego Funduszu Morskiego i Rybackiego (EFMR), które działają w ramach wspólnych ram (europejskie fundusze strukturalne i inwestycyjne - „EFSI”). Ponadto, ustanawia ono również przepisy niezbędne do zapewnienia skuteczności EFSI, a także koordynacji tych funduszy między sobą oraz z innymi instrumentami Unii.

Zgodnie z art. 19 rozporządzenia 1303/2013 ustanowiono cele tematyczne, które stanowią przedmiot wsparcia opisywanych funduszy. Pośród jedenastu celów ${ }^{16}$, które wszystkie w sposób pośredni dotyczą spójnego wzrostu i konkurencyjności, w pkt. 3 wskazano jako jeden z celów wzmacnianie konkurencyjności MŚP, sektora rolnego (w odniesieniu do EFRROW) oraz sektora rybołówstwa i akwakultury (w odniesieniu do EFMR).

15 Rozporządzenie Parlamentu Europejskiego i Rady (UE) nr 1303/2013 z dnia 17 grudnia 2013 r. ustanawiające wspólne przepisy dotyczące Europejskiego Funduszu Rozwoju Regionalnego, Europejskiego Funduszu Społecznego, Funduszu Spójności, Europejskiego Funduszu Rolnego na rzecz Rozwoju Obszarów Wiejskich oraz Europejskiego Funduszu Morskiego i Rybackiego oraz ustanawiające przepisy ogólne dotyczące Europejskiego Funduszu Rozwoju Regionalnego, Europejskiego Funduszu Społecznego, Funduszu Spójności i Europejskiego Funduszu Morskiego i Rybackiego oraz uchylające rozporządzenie Rady (WE) nr 1083/2006 (Dz. Urz. UE L Nr 342, s. 320 z późn. zm.).

16 Do innych celów zaliczono: wzmacnianie badań naukowych, rozwoju technologicznego i innowacji; zwiększenie dostępności, stopnia wykorzystania i jakości TIK; wspieranie przejścia na gospodarkę niskoemisyjną we wszystkich sektorach; promowanie dostosowania do zmian klimatu, zapobiegania ryzyku i zarządzania ryzykiem; zachowanie i ochrona środowiska naturalnego oraz wspieranie efektywnego gospodarowania zasobami; promowanie zrównoważonego transportu i usuwanie niedoborów przepustowości w działaniu najważniejszej infrastruktury sieciowej; promowanie trwałego i wysokiej jakości zatrudnienia oraz wsparcie mobilności pracowników; promowanie włączenia społecznego, walka z ubóstwem i wszelką dyskryminacją; inwestowanie w kształcenie, szkolenie oraz szkolenie zawodowe na rzecz zdobywania umiejętności i uczenia się przez całe życie; wzmacnianie zdolności instytucjonalnych instytucji publicznych i zainteresowanych stron oraz sprawności administracji publicznej. 
$\mathrm{Na}$ zasadach ogólnych rozporządzenie reguluje także zawieranie umów partnerstwa ${ }^{17}$ pomiędzy krajami członkowskimi a instytucjami UE w zakresie finansowania konkretnych celów szczegółowych ${ }^{18}$. Na tej podstawie udzielana jest dalsza pomoc finansowa. Ponadto, w rozporządzeniu określono procedurę ustanawiania programów, które określają strategię dotyczącą wkładu programu do unijnej strategii na rzecz inteligentnego i zrównoważonego wzrostu sprzyjającego włączeniu społecznemu, która jest zgodna $\mathrm{z}$ rozporządzeniem, przepisami dotyczącymi poszczególnych funduszy i z treścią umowy partnerstwa ${ }^{19}$. Określa się także instrumenty finansowe dostępne w ramach funduszy ${ }^{20}$.

Rozporządzenie to jest podstawą rozdysponowania funduszy europejskich oraz określa procedury związane z programowaniem pomocy. Ma charakter instrukcji techniczno-proceduralnych. Jego stosowanie umożliwia finansowanie wszystkich funduszy rolnych, monitorowanie, ewolucję oraz rozliczanie poszczególnych instrumentów finansowych ${ }^{21}$. Stanowi ono podstawę do określania dalszych instrumentów prawnych kształtujących cele WPR.

\subsubsection{Rozporządzenie $1305 / 2013$}

Kluczowym dla dalszych analiz przedstawianych w rozdziale czwartym instrumentów prawnych jest rozporządzenie Parlamentu Europejskiego i Rady (UE) nr 1305/2013 z dnia 17 grudnia 2013 r. w sprawie wsparcia rozwoju obszarów wiejskich przez Europejski Fundusz Rolny na rzecz Rozwoju Obszarów Wiejskich (EFRROW) i uchylające rozporządzenie Rady (WE) nr 1698/200522. Rozporządzenie to zgodnie

17 K. Bandarzewski, Umowa partnerstwa jako podstawa realizacji nowej perspektywy finansowania rozwoju regionalnego w latach 2014-2020, [w:] Rozwój regionalny-instrumenty realizacji i rola samorządu województwa, K. Bandarzewski, M. Stec (red.), Warszawa 2015.

18 A. Harasimowicz, Fundusze Strukturalne i Fundusz Spójności jako instrumenty realizacji polityki regionalnej Unii Europejskiej, Białystok 2012; R. Poździk, Zasady wdrażania funduszy unijnych w latach 2014-2020, „Europejski Przegląd Sądowy”, 2014, nr 12, s. 4-11.

19 B. Jóźwik, M. Sagan, T. Stępniewski, Polityka spójności Unii Europejskiej. Doświadczenia, wnioski i rekomendacje na lata 2014-2020, Lublin 2012.

$20 \mathrm{~K}$. Brysiewicz, Dofinansowanie ze środków europejskich w orzecznictwie Sądu Najwyższego i sądów powszechnych, „Monitor Prawniczy”, 2014, nr 17, s. 895-903.

21 J. Łacny, Korekty finansowe nakładane przez Komisję Europejska na państwa członkowskie za niezgodne z prawem wydatkowanie funduszy Unii Europejskiej, Warszawa 2017.

22 Rozporządzenie Parlamentu Europejskiego i Rady (UE) nr 1305/2013 z dnia 17 grudnia 2013 r. w sprawie wsparcia rozwoju obszarów wiejskich przez Europejski Fundusz Rolny na rzecz Rozwoju Obszarów Wiejskich (EFRROW) i uchylające rozporządzenie Rady (WE) nr 1698/2005 (Dz. Urz. UE L Nr 347, s. 487 z późn. zm.); por. także rozporządzenie delegowane Komisji (UE) nr 807/2014 z dnia 11 marca 2014 r. uzupełniające rozporządzenie Parlamentu Europejskiego i Rady (UE) nr 1305/2013 w sprawie wsparcia rozwoju obszarów wiejskich przez Europejski Fundusz Rolny na rzecz Rozwoju Obszarów Wiejskich (EFRROW) i wprowadzające przepisy przejściowe (Dz. Urz. UE L Nr 227, s. 1); rozporządzenie wykonawcze Komisji (UE) nr 808/2014 z dnia 17 lipca 2014 r. ustanawiające zasady stosowania rozporządzenia Parlamentu Europejskiego i Rady (UE) nr 1305/2013 w sprawie wsparcia 
$\mathrm{z}$ art. 1 ustanawia ogólne przepisy regulujące wsparcie Unii dla rozwoju obszarów wiejskich, finansowane z Europejskiego Funduszu Rolnego na rzecz Rozwoju Obszarów Wiejskich (EFRROW) oraz ustanowione rozporządzeniem (UE) nr 1306/2013. Określa ono cele, do realizacji których ma przyczyniać się polityka rozwoju obszarów wiejskich, oraz odpowiednie priorytety unijne w zakresie polityki rozwoju obszarów wiejskich. W tym rozporządzeniu nakreśla się kontekst strategiczny polityki rozwoju obszarów wiejskich oraz określa się działania, jakie należy podjąć w celu realizacji polityki rozwoju obszarów wiejskich. Ponadto, ustanawia ono przepisy dotyczące programowania, tworzenia sieci kontaktów, zarządzania, monitorowania i ewaluacji na podstawie obowiązków dzielonych przez państwa członkowskie i Komisję oraz przepisy służące zapewnieniu koordynacji EFRROW z innymi instrumentami unijnymi.

Jako jeden z celów przyczyniających się do rozwoju obszarów wiejskich w art. 4 deklaruje się wspieranie konkurencyjności rolnictwa. Ponadto, co odpowiada ewolucji WPR w kierunku prośrodowiskowym, określa się zapewnienie zrównoważonego zarządzania zasobami naturalnymi oraz działania w dziedzinie klimatu, a także osiągnięcie zrównoważonego rozwoju terytorialnego wiejskich gospodarek i społeczności ${ }^{23}$, w tym tworzenie i utrzymywanie miejsc pracy. Deklarowany główny cel w tym rozporządzeniu wskazuje na nadal silną pozycję instrumentów prawnych wspierających konkurencyjność rolnictwa.

Wskazuje się również w art. 5 pkt 1 rozporządzenia jako jeden z celów tematycznych zwiększenie rentowności gospodarstw i konkurencyjności wszystkich rodzajów rolnictwa we wszystkich regionach oraz promowanie innowacyjnych technologii w gospodarstwach i zrównoważonego zarządzania lasami, obejmujące następujące cele szczegółowe, takie jak: poprawa wyników gospodarczych wszystkich gospodarstw oraz ułatwianie restrukturyzacji i modernizacji gospodarstw, szczególnie z myślą o zwiększeniu uczestnictwa w rynku i zorientowania na rynek, a także zróżnicowania produkcji rolnej oraz ułatwianie wejścia rolników, posiadających odpowiednie umiejętności do sektora rolnictwa, a w szczególności wymiany pokoleń. Konkurencyjność staje się jednym z podstawowych priorytetów polityki rozwoju obszarów wiejskich.

Rozporządzenie określa również procedurę uchwalania, zawartość oraz ocenę programów rozwojów obszarów wiejskich. Są to obszerne dokumenty programowe, w których dane państwo przeprowadza analizę ekonomiczną, a przede wszystkim określone w art. 8 ust. 1 lit. b analizy SWOT. Głównym elementem PROW jest opis każdego z wybranych działań. Państwo członkowskie samo dokonuje wyboru $\mathrm{z}$ zaproponowanych $\mathrm{w}$ rozporząadzeniu instrumentów prawnych i wdraża je w prawie

rozwoju obszarów wiejskich przez Europejski Fundusz Rolny na rzecz Rozwoju Obszarów Wiejskich (EFRROW) (Dz. Urz. UE L Nr 227, s. 18).

23 M. Szymańska, Zasada zrównoważonego rozwoju rolnictwa $w$ świetle uregulowań gatęzi prawa i polityki rolnej, „Studia Iuridica Lublinensia”, 2016, t 25, nr 1. 
krajowym. Spośród kilkudziesięciu mechanizmów prawnych (część z nich szczegółowo jest opisana w następnym rozdziale) państwo dokonuje wyboru kilkunastu (czasami około 20) instrumentów prawnych, które mają osiągnąć cele WPR ${ }^{24}$.

Przeprowadzenie właściwej oceny ekonomicznej oraz analizy SWOT jest kluczem do wskazania na przyszłą efektywność wybranych mechanizmów prawnych. Ich niewłaściwy dobór może spowodować w najlepszym przypadku brak zainteresowania rolników i konieczność zwrotu środków do budżetu UE. W najgorszym zaś, przy niewłaściwym wykorzystaniu środków przez rolników nałożenie na nich kar. Dlatego też dobór odpowiednich mechanizmów nie tylko powinien urzeczywistniać cele WPR, ale także być systemem zachęt dla rolników.

\subsubsection{Rozporządzenie $1306 / 2013$}

Rozporządzenie Parlamentu Europejskiego i Rady (UE) nr 1306/2013 z dnia 17 grudnia 2013 r. w sprawie finansowania wspólnej polityki rolnej, zarządzania nią i monitorowania jej oraz uchylające rozporządzenia Rady: (EWG) $\mathrm{nr}$ 352/78, (WE) nr 165/94, (WE) nr 2799/98, (WE) nr 814/2000, (WE) nr 1290/2005 i (WE) nr 485/200825 dotyczy m.in. finansowania wydatków w ramach wspólnej polityki rolnej (WPR), w tym wydatków na rozwój obszarów wiejskich; systemu doradztwa rolniczego; systemów zarządzania i kontroli, które mają być wprowadzone przez państwa członkowskie; systemu zasady wzajemnej zgodności; czy rozliczenia rachunków. Szczegółowo określa wydatki poprzez Europejski Fundusz Rolniczy Gwarancji (EFRG) oraz Europejski Fundusz Rolny na rzecz Rozwoju Obszarów Wiejskich (EFRROW).

Określa ponadto ramy instytucjonalne przyznawania pomocy, w szczególności wskazując na akredytację agencji płatniczych ${ }^{26}$. W tym zakresie pewność stosowanych rozwiązań oraz jakość rozdysponowywania środków poprzez wyspecjalizowane instytucje staje się gwarantem proceduralnym konkurencyjności.

\subsubsection{Rozporządzenie 1307/2013}

Podstawowym aktem prawnym, który wprowadza powszechność pomocy dla rolników jest rozporządzenie Parlamentu Europejskiego i Rady (UE) nr 1307/2013 z dnia 17 grudnia 2013 r. ustanawiające przepisy dotyczące płatności bezpośrednich

24 Por. A. Germanò, G. Strambi, Wdrażanie Programów Rozwoju Obszarów Wiejskich we Włoszech na podstawie rozporządzenia 1305/2013, „Przegląd Prawa Rolnego”, 2016, t. 19, nr 2.

25 Rozporządzenie Parlamentu Europejskiego i Rady (UE) nr 1306/2013 z dnia 17 grudnia 2013 r. w sprawie finansowania wspólnej polityki rolnej, zarządzania nią i monitorowania jej oraz uchylające rozporządzenia Rady: (EWG) nr 352/78, (WE) nr 165/94, (WE) nr 2799/98, (WE) nr 814/2000, (WE) nr 1290/2005 i (WE) nr 485/2008 (Dz. Urz. UE L Nr 347, s. 549 z późn. zm.).

26 A. Stelmachowski, Agencje interwencyjne: Agencja Rynku Rolnego oraz Agencja Restrukturyzacji i Modernizacji Rolnictwa, [w:] Prawo rolne, A. Stelmachowski (red.), Warszawa 2009, s. 430-443. 
dla rolników na podstawie systemów wsparcia w ramach wspólnej polityki rolnej oraz uchylające rozporządzenie Rady (WE) nr 637/2008 i rozporządzenie Rady (WE) nr 73/200927. Określa ono zasady przyznawania płatności bezpośrednich. Stanowi również podstawę prawną do wprowadzania do systemu prawnego instrumentów związanych z polityką zazieleniania WPR. Szczegółowa analiza instrumentów prawnych w tym zakresie znajduje się w rozdziale czwartym.

Rozporządzenie 1307/2013 jest podstawowym aktem prawnym, który wpływa na konkurencyjność rolnictwa. Powszechność udzielanej pomocy w zakresie wsparcia bezpośredniego wskazuje na zasadniczy wpływ tego instrumentu prawnego na kształt współczesnego rolnictwa europejskiego. Trzeba również zwrócić uwagę, że mechanizm płatności bezpośrednich jest instrumentem prawnym, który podlegał największym zmianom w każdym okresie programowania ${ }^{28}$. Opisywana polityka zazieleniania jest przykładem takiej zmiany, a co za tym idzie stanowi podstawę analiz oddziaływania tego mechanizmu na konkurencyjność rolnictwa.

\subsubsection{Rozporządzenie $1308 / 2013$}

Ostatnim omawianym rozporządzeniem, mającym bezpośrednio wpływ na konkurencyjność rolnictwa, jest rozporządzenie Parlamentu Europejskiego i Rady (UE) $\mathrm{nr}$ 1308/2013 z dnia 17 grudnia 2013 r. ustanawiające wspólną organizację rynków produktów rolnych oraz uchylające rozporządzenia Rady (EWG) nr 922/72, (EWG) nr 234/79, (WE) nr 1037/2001 i (WE) nr 1234/200729. Określa ono nie tylko wewnętrzną organizację rynku rolnego $\mathrm{UE}^{30}$, lecz także wskazuje na ważne mechanizmy prawne w handlu z państwami trzecimi. Ich szczegółowa analiza znajduje się w rozdziale czwartym ${ }^{31}$.

27 Rozporządzenie Parlamentu Europejskiego i Rady (UE) nr 1307/2013 z dnia 17 grudnia 2013 r. ustanawiające przepisy dotyczące płatności bezpośrednich dla rolników na podstawie systemów wsparcia w ramach wspólnej polityki rolnej oraz uchylające rozporządzenie Rady (WE) nr 637/2008 i rozporządzenie Rady (WE) nr 73/2009 (Dz. Urz. UE L Nr 347, s. 608 z późn. zm.).

28 E. Tomkiewicz, Wspólna polityka rolna po reformie z 2003 r., „Studia Iuridica Agraria”, Białystok 2005 , t. 5 , s. $211-220$.

29 Rozporządzenie Parlamentu Europejskiego i Rady (UE) nr 1308/2013 z dnia 17 grudnia 2013 r. ustanawiające wspólną organizację rynków produktów rolnych oraz uchylające rozporządzenia Rady (EWG) nr 922/72, (EWG) nr 234/79, (WE) nr 1037/2001 i (WE) nr 1234/2007 (Dz. Urz. UE L Nr 347, s. $671 \mathrm{z}$ późn. zm.).

30 P. Czechowski, M. Korzycka-Iwanow, S. Prutis, A. Stelmachowski, Polskie prawo rolne na tle ustawodawstwa Unii Europejskiej, Warszawa 2002, s. 206-223; P. Czechowski, Proces dostosowania polskiego prawa rolnego i żywnościowego do prawa Unii Europejskiej, Warszawa 2001, s. 201-246; P. Czechowski, Dostosowanie polskiego prawa rolnego i żywnościowego do prawa wspólnotowego po akcesji do Unii Europejskiej, Warszawa 2005, s. 38-49.

31 O krajowej organizacji rynków rolnych por. P. Czechowski, A. Niewiadomski, Europejskie rynki rolne, [w:] Prawo rolne, A. Stelmachowski (red.), Warszawa 2009, s. 369-412. 
Należy wskazać, że od 2008 r. jest utrzymywane podejście horyzontalne w organizacji jednolitego rynku rolnego ${ }^{32}$. Oznacza to możliwości wypracowania wspólnych mechanizmów obowiązujących w poszczególnych branżach ${ }^{33}$. Niewątpliwie takie podejście wpisuje się w uproszczenie WPR, a co za tym idzie sprzyja wzrostowi konkurencyjności rolnictwa.

Należy również wskazać na ograniczanie „twardych” mechanizmów protekcjonistycznych, takich jak przykładowo interwencja publiczna. Obecnie sprowadza się ona do bardzo szczególnych przypadków określonych produktów rolnych w odpowiednich okresach czasowych. Stosowanie instrumentów mniej ingerujących w rynek rolny wydaje się mechanizmem skuteczniejszym, a także poprawiającym jakość produktów. Dość wspomnieć tutaj nomenklaturę scaloną, czy nadzwyczajne środki interwencji w przypadku pojawienia się chorób odzwierzęcych.

\subsubsection{Dyrektywy europejskie}

Ważnym rodzajem aktów prawnych, wpływających na konkurencyjność rolnictwa, są dyrektywy europejskie. Co prawda nie są to akty prawne o bezpośrednim skutku ${ }^{34}$ i są adresowane do państw członkowskich, ale ich odpowiednia recepcja do prawa krajowego bezpośrednio wpływa na konkurencyjność rolnictwa ${ }^{35}$.

Jednym z przykładów takich aktów prawnych jest tzw. dyrektywa wodna, czyli dyrektywa 2000/60/WE Parlamentu Europejskiego i Rady z dnia 23 października 2000 r. ustanawiająca ramy wspólnotowego działania w dziedzinie polityki wodnej ${ }^{36}$. Jej celem jest ustalenie ram dla ochrony śródlądowych wód powierzchniowych,

32 I. Lipińska, Nowe przepisy w zakresie organizacji wspólnotowego rynku rolnego, „Przegląd Prawa Rolnego", 2008, nr 1, s. 179; P. Czechowski, Standardy harmonizacji prawa, [w:] Prawo polskie a prawo Unii Europejskiej, E. Piontek (red.), Warszawa 2003, s. 67-72.

33 P. Pytlak, Znaczenie i charakter umów w systemie mechanizmów regulujacych branżowe rynki rolne, „Rejent”, 2006, nr 3, s. 93.

34 M. Domańska, Implementacja dyrektyw unijnych przez sądy krajowe, Warszawa 2014.

35 L. Costato, Wplyw wspólnotowego prawa rolnego na prawo rolne wewnętrzne, „Przegląd Prawa Rolnego", 2007, nr 1.

36 Dyrektywa 2000/60/WE Parlamentu Europejskiego i Rady z dnia 23 października 2000 r. ustanawiająca ramy wspólnotowego działania w dziedzinie polityki wodnej (Dz. Urz. UE L Nr 327, s. 1). Inne dyrektywy dotyczące gospodarki wodnej na obszarach wiejskich to: dyrektywa Rady 91/271/EWG z dnia 21 maja 1991 r. dotycząca oczyszczania ścieków komunalnych (Dz. Urz. WE L Nr 135, s. 40 z późn. zm.); dyrektywa Rady 91/676/EWG z dnia 12 grudnia 1991 r. dotycząca ochrony wód przed zanieczyszczeniami powodowanymi przez azotany pochodzenia rolniczego (Dz. Urz. WE L Nr 375, s. 1 z późn. zm.); dyrektywa 2006/7/WE Parlamentu Europejskiego i Rady z dnia 15 lutego 2006 r. dotycząca zarządzania jakością wody w kąpieliskach i uchylająca dyrektywę 76/160/EWG (Dz. Urz. UE L nr 64, s. 37 z późn. zm.); dyrektywa 2006/118/WE Parlamentu Europejskiego i Rady z dnia 12 grudnia 2006 r. w sprawie ochrony wód podziemnych przed zanieczyszczeniem i pogorszeniem ich stanu (Dz. Urz. UE L Nr 372, s. 19 z późn. zm.); dyrektywa Parlamentu Europejskiego i Rady 2008/105/WE z dnia 16 grudnia 2008 r. w sprawie środowiskowych norm jakości w dziedzinie polityki wodnej, zmieniającą i w następstwie uchylającą dyrektywy Rady 82/176/EWG, 83/513/EWG, 84/156/EWG, 84/491/EWG i 86/280/EWG 
wód przejściowych, wód przybrzeżnych oraz wód podziemnych, które m.in. zapobiegają dalszemu pogarszaniu oraz chronią i poprawiają stan ekosystemów wodnych oraz, w odniesieniu do ich potrzeb wodnych, ekosystemów lądowych i terenów podmokłych bezpośrednio uzależnionych od ekosystemów wodnych. Niewątpliwe podejście do wykorzystania wody w produkcji rolnej po wydaniu tej dyrektywy i wdrożeniu jej do polskiego ustawodawstwa wpłynęło na rolnictwo oraz na jego konkurencyjność.

Innym przykładem są dyrektywy ${ }^{37}$, które umożliwiły stworzenie w Polsce obszarów Natura 2000. Pozwoliły one w ustawie z dnia 16 kwietnia 2004 r. o ochronie przyrody ${ }^{38}$ na określenie aktów prawnych normujących sytuację prawną rolnika na obszarach Natura $2000^{39}$. Plany zadań ochronnych, które są zarządzeniami Regionalnego Dyrektora Ochrony Środowiska kształtują prawo własności nieruchomości rolnych. Poprzez system wprowadzanych zakazów i nakazów wpływają na konkurencyjność rolnictwa na tych terenach.

Przedstawione dyrektywy są tylko przykładami z kilkuset innych, które oddziałują na działalność rolniczą. Ich omówienie ze względu na status prawny i cel rozprawy wydaje się niecelowe. Jednakże warto o nich pamiętać, gdyż określane przez nich założenia w bezpośredni sposób wpływają na krajowe instrumenty prawne powodujące wzrost konkurencyjności rolnictwa.

\subsubsection{Akty o charakterze nienazwanym typu soft law}

W katalogu źródeł prawa europejskiego znajduje się szereg aktów prawnych, które nie są zaliczane do prawa powszechnie obowiązującego ${ }^{40}$. Są one zaleceniami, określeniami celów, czy też odpowiednimi wytycznymi do przygotowywania aktów

oraz zmieniającą dyrektywę 2000/60/WE Parlamentu Europejskiego i Rady (Dz. Urz. UE L Nr 348, s. 84 z późn. zm.). W Polsce na jej podstawie ustanowiono Ustawę z dnia 20 lipca 2017 r. Prawo wodne (Dz. U. z 2018 r. poz. 2268 z późn. zm.).

37 Dyrektywa 79/409/EWG Rady z dnia 2 kwietnia 1979 r. o ochronie dziko żyjących ptaków (Dz. Urz. UE L z 1979 r. Nr 103, s. 1 z późn. zm.), która została zastąpiona nową dyrektywą 2009/147/WE Parlamentu Europejskiego i Rady z dnia 30 listopada 2009 r. w sprawie ochrony dzikiego ptactwa (Dz. Urz. UE L z 2010 r. Nr 20, s. 7 z późn. zm.) oraz dyrektywa 92/43EWG Rady z dnia 21 maja 1992 r. w sprawie ochrony siedlisk przyrodniczych oraz dzikiej fauny i flory (Dz. Urz. UE L z 1992 r. Nr 206, s. 7 z późn. zm.)

38 Ustawa z dnia 16 kwietnia 2004 r. o ochronie przyrody (Dz. U. z 2015 r. poz. 1651 z późn. zm.)

39 A. Habuda, Prawne skutki utworzenia obszaru Natura 2000 z perspektywy wtaściciela nieruchomości, [w:] Gospodarowanie w dolinach rzecznych na obszarach Natura 2000 - problemy działalności inwestycyjnej, B. Pawluśkiewicz (red.), Warszawa 2015, s. 41-53; A. Niewiadomski, Publicznoprawny i prywatnoprawny konflikt interesów na przykladzie Europejskiej Sieci Ekologicznej Natura 2000, Warszawa 2017; B. Jeżyńska, Obszary Natura 2000 w ramach Wspólnej Polityki Rolnej Unii Europejskiej, [w:] Problemy wdrażania systemu Natura 2000 w Polsce, A. Kaźmierska-Patrzyczna, M.A. Król (red.), Szczecin-Łódź-Poznań, 2013; M.A. Król, Sytuacja prawna prowadzacego działalność rolnicza na obszarach Natura 2000, [w:] Problemy wdrażania systemu Natura 2000 w Polsce, A. KaźmierskaPatrzyczna, M.A. Król (red.), Szczecin-Łódź-Poznań, 2013.

40 F. Beveridge, S. Nott, a Hard Look on the Soft Law, [w:] Lawmaking in the European Union, P. Craig, C. Harlow (red.), Boston 1998. 
prawnych. Nie oddziałują bezpośrednio na konkurencyjność rolnictwa. Jednakże ich odpowiednie zastosowanie wpływa na kształt polityki rolnej oraz dobór instrumentów prawnych dla jej realizacji.

Wspomniane komunikaty Komisji w rozdziale 2 odnoszące się do przyszłości WPR po 2020 r. są doskonałym tego przykładem. Ustalanie stanowisk pomiędzy organami UE zaowocowało przesłaniem konkretnych projektów rozporządzeń. Ich wydanie jest poprzedzone właśnie regulacjami o charakterze soft law $w^{41}$.

Innym przykładem tego typu aktów prawnych jest rezolucja Parlamentu Europejskiego z dnia 27 kwietnia 2017 r. w sprawie aktualnego stanu koncentracji gruntów rolnych w UE: jak ułatwić rolnikom dostęp do gruntów? ${ }^{42}$. Wskazuje ona na możliwości wprowadzenia do regulacji krajowych odpowiednich instrumentów prawnych (np. kwalifikacje rolnicze, kontrola obrotu) oddziałujących na obrót nieruchomościami rolnymi ${ }^{43}$. Te mechanizmy pośrednio wpływają na konkurencyjność rolnictwa poprzez kształtowanie dostępności do warsztatu pracy rolnika, jakim jest gospodarstwo rolne. Podobne mechanizmy, aczkolwiek w niektórych miejscach wykluczające te przewidziane w rezolucji, określa „Komunikat wyjaśniający Komisji w sprawie nabywania gruntów rolnych i prawa Unii Europejskiej” z 18 października 2017 r. ${ }^{44}$

Powyższe przykłady wskazują na poszerzanie się aktów prawnych, które kształtują instrumenty prawne wpływające na konkurencyjność w rolnictwie. Trzeba brać pod uwagę, że rola tego typu dokumentów będzie wzrastała. Podobnie zresztą jak ich ilość. Dla nauki prawa rolnego będzie to problem z uwagi na dość niski status tych aktów w hierarchii źródeł prawa.

\subsection{Regulacje krajowe dotyczące konkurencyjności rolnictwa}

Podobnie jak na gruncie europejskim, tak i w polskim systemie prawa istnieją regulacje prawne, które systemowo wpływają na konkurencyjność rolnictwa. Określenie regulacji kształtujących dany instrument prawny wymaga poszukiwania jego powiązań w kilku, czasami kilkunastu aktach prawnych.

41 W. Bańczyk, ,Miękkie prawo, ale prawo”, czyli o obowiązu przestrzegania soft law, „Internetowy Przegląd Prawniczy TBSP UJ", 2016, nr 1.

$42 \mathrm{http}: / /$ www.europarl.europa.eu/sides/getDoc.do?pubRef=-//EP//TEXT+TA+P8-TA-2017-0197+0+ $\mathrm{DOC}+\mathrm{XML}+\mathrm{V} 0 / /$ PL\&language $=\mathrm{PL}$ [data dostępu 30 marca 2019 r.].

43 E. Ura, K. Heliniak, Ograniczenia własności nieruchomości w administracyjnym prawie materialnym, [w:] Jednostka wobec działań administracji publicznej, E. Ura (red.), Rzeszów 2001; M. Szewczyk, Ingerencja publicznoprawna w prawo własności jednostki $w$ demokratycznym państwie prawnym, [w:] Jednostka w demokratycznym państwie prawa, J. Filipek (red.), Bielsko-Biała 2003.

$44 \mathrm{https}$ ://eur-lex.europa.eu/legal-content/PL/TXT/?uri=CELEX\%3A52017XC1018\%2801\%29 [data dostępu 30 marca 2019 r.]. 
Przedstawiony poniżej przegląd najważniejszych źródeł prawa w tym zakresie został skonstruowany z uwagi na cele rozprawy. Nie wyczerpuje on pełnego katalogu regulacji krajowych, które dotyczą konkurencyjności rolnictwa.

\subsubsection{Regulacje konstytucyjne}

W Konstytucji $\mathrm{RP}^{45} \mathrm{w}$ art. 23 określono, iż podstawą ustroju rolnego jest gospodarstwo rodzinne ${ }^{46}$. Sama ta konstatacja pozwala domniemać uprzywilejowanie, a co za tym idzie wypracowanie mechanizmów ułatwiających konkurencję $\mathrm{z}$ dużymi podmiotami rolnymi. Gospodarstwo rodzinne ${ }^{47}$ znajduje swoje odzwierciedlenie w ustawie o kształtowaniu ustroju rolnego ${ }^{48}$. Przyznanie preferencji dla rolników indywidualnych w nabywaniu nieruchomości rolnej wpływa na podniesienie poziomu ich konkurencyjności. W gospodarstwach o tradycyjnym charakterze czynnik ziemi nadal stanowi istotny składnik alokacji zasobów.

Z przywołanej normy konstytucyjnej na razie wypływają tylko konsekwencje związane z obrotem nieruchomościami rolnymi ${ }^{49}$. Nic nie stoi jednak na przeszkodzie, aby w przyszłości przyznać rolnikom prowadzącym gospodarstwa rodzinne dalsze uprawnienia. Do tego zmierzają także unormowania europejskie, które już obecnie preferują gospodarstwa rodzinne.

\subsubsection{Unormowania ustawowe}

W dalszej części pracy zostaną zaprezentowane najważniejsze ustawy dotyczące konkurencyjności rolnictwa. W dużej mierze są one efektem obowiązujących unormowań europejskich i omawianych w poprzednim podrozdziale rozporządzeń.

45 Konstytucja Rzeczypospolitej Polskiej z dnia 2 kwietnia 1997 r. (Dz. U. poz. 483 z późn. zm.).

46 M. Zubik, Gospodarstwo rodzinne - niedoceniona szansa współksztaltowania konstytucyjnych podstaw ustroju rolnego poprzez sadownictwo konstytucyjne, [w:] Prawne mechanizmy wspierania i ochrony rolnictwa rodzinnego w Polsce i innych państwach Unii Europejskiej, P. Litwiniuk (red.), Warszawa 2015; D. Puślecki, Prawne pojęcie gospodarstwa rodzinnego, „Zeszyty Naukowe SERiA”, 2016, $\mathrm{nr}$ 2; M. Korzycka, Kontekst historyczno-polityczny i naukowy normy konstytucyjnej o ustroju rolnym państwa polskiego, [w:] Państwo i Prawo. Księga Jubileuszowa Prokuratorii Generalnej Rzeczypospolitej Polskiej, L. Bosek (red.), Warszawa 2017.

47 D. Łobos, Model gospodarstwa rodzinnego w ustawodawstwie Wspólnot Europejskich oraz w ustawodawstwach narodowych państw członkowskich Wspólnot Europejskich, [w:] Prawo rolne u progu Unii Europejskiej, S. Prutis (red.), Białystok 1998; A. Lichorowicz, Status prawny gospodarstw rodzinnych w ustawodawstwie krajów Europy Zachodniej, Białystok 2000; T. Kurowska, Gospodarstwo rodzinne czy gospodarstwo rozwojowe. Dylematy wyboru, [w:] Prawo rolne u progu Unii Europejskiej, S. Prutis (red.), Białystok 1998.

48 Ustawa z dnia 11 kwietnia 2003 r. o kształtowaniu ustroju rolnego (Dz. U. z 2017 r. poz. 2196 z późn. zm.).

49 A. Jurcewicz, Przemiany własności w rolnictwie - kontekst systemowy z perspektywy prawa krajowego i unijnego, „Studia Prawnicze”, 2014, nr 1. 
Analizowane ustawy nie wyczerpują wszystkich unormowań dotyczących konkurencyjności rolnictwa. Poza zakresem rozważań pozostaje system podatkowy, ubezpieczenia społeczne rolników, czy unormowania wynikające z prawa żywnościowego. $\mathrm{Z}$ uwagi na cel rozprawy badaniu poddano tylko te ustawy, które w bezpośredni sposób dotyczą konkurencyjności rolnictwa ${ }^{50}$.

\subsubsection{Ustawa o wspieraniu rozwoju obszarów wiejskich z udziałem środków Europejskiego Funduszu Rolnego na rzecz Rozwoju Obszarów Wiejskich w ramach Programu Rozwoju Obszarów Wiejskich na lata 2014-2020}

Podstawową ustawą określającą ramy konkurencyjności rolnictwa jest ustawa z dnia 20 lutego 2015 r. o wspieraniu rozwoju obszarów wiejskich z udziałem środków Europejskiego Funduszu Rolnego na rzecz Rozwoju Obszarów Wiejskich w ramach Programu Rozwoju Obszarów Wiejskich na lata 2014-202051. Nawiązuje ona do rozporządzenia nr 1305/2013. Określa, zgodnie z art. 1, zadania oraz właściwość organów i jednostek organizacyjnych w zakresie dotyczącym wspierania rozwoju obszarów wiejskich z udziałem środków Europejskiego Funduszu Rolnego na rzecz Rozwoju Obszarów Wiejskich w ramach Programu Rozwoju Obszarów Wiejskich na lata 2014-2020. Ponadto, precyzuje proceduralne warunki i tryb przyznawania, wypłaty i zwrotu pomocy finansowej przede wszystkim w ramach działań i poddziałań objętych programem.

Ustawa wskazuje również zasady wdrażania instrumentów finansowych w zakresie nieokreślonym w przepisach rozporządzeń europejskich lub przewidzianym $w$ tych przepisach do określenia przez państwo członkowskie Unii Europejskiej. W art. 3 ustawy wskazano instrumenty prawne, które Polska wybrała jako te w najlepszy sposób odpowiadające potrzebom polskiego rolnictwa. Ich szczegółowa analiza zostanie przedstawiona w kolejnym rozdziale. Tu należy tylko wspomnieć, że obejmuje ona zarówno mechanizmy prośrodowiskowe, inwestycyjne, jak i społeczne.

Ustawa określa także procedury związane z uzyskiwaną pomocą. Wskazuje również na delegacje ustawowe umożliwiające wydanie rozporządzeń wykonawczych. Określa elementy decyzji przyznającej płatność, umowy o płatność, czy postępowanie z wnioskiem o płatność. W końcu reguluje już podnoszoną przeze mnie bardzo ważną kwestię doradztwa dla rolników w zakresie możliwości uzyskiwania pomocy.

Ponadto, w ustawie utworzono Krajową Sieć Obszarów Wiejskich (KSOW) do której należy instytucja zarządzająca - jako jednostka centralna; samorządy województw

50 Por. także ustawa z dnia 27 maja 2015 r. o finansowaniu wspólnej polityki rolnej (Dz. U. z 2018 r. poz. 719 z późn. zm.); ustawa z dnia 20 lutego 2015 r. o rozwoju lokalnym z udziałem lokalnej społeczności (Dz. U. z 2018 r. poz. 140 z późn. zm.).

51 Ustawa z dnia 20 lutego 2015 r. o wspieraniu rozwoju obszarów wiejskich z udziałem środków Europejskiego Funduszu Rolnego na rzecz Rozwoju Obszarów Wiejskich w ramach Programu Rozwoju Obszarów Wiejskich na lata 2014-2020 (Dz. U. z 2018 r. poz. 627 z późn. zm.). 
- jako jednostki regionalne; wojewódzkie ośrodki doradztwa rolniczego - jako jednostki realizujące w poszczególnych województwach zadania KSOW; CDR - jako jednostka koordynująca realizację zadań KSOW.

W tej ustawie znajduje się większość instrumentów prawnych wynikających z PROW 2014-2020 oraz rozporządzenia 1305/2013 (tych, które wybrała Polska). Stanowią one osobny szczegółowy przedmiot analizy w rozdziale czwartym.

\subsubsection{Ustawa o płatnościach $w$ ramach systemów wsparcia bezpośredniego}

Aktem prawnym nawiązującym do rozporządzenia 1307/2013 jest ustawa z dnia 5 lutego 2015 r. o płatnościach w ramach systemów wsparcia bezpośredniego ${ }^{52}$. Określa ona zadania oraz właściwość organów i jednostek organizacyjnych w zakresie dotyczącym płatności bezpośrednich: jednolitej płatności obszarowej, płatności za zazielenienie, płatności dla młodych rolników, płatności dodatkowej, płatności związanych do powierzchni upraw, płatności związanych do zwierząt i płatności dla małych gospodarstw. Instrumenty te zostaną omówione w odrębnym podrozdziale rozdziału czwartego.

Ponadto, w ustawie określono zasady i tryb przyznawania rolnikom płatności bezpośrednich i płatności niezwiązanej do tytoniu; przeprowadzania kontroli w zakresie płatności bezpośrednich oraz płatności niezwiązanej do tytoniu, a także wypłaty rolnikom płatności bezpośrednich i płatności niezwiązanej do tytoniu.

Bardzo szczegółowe określenie kryteriów dostępu do poszczególnego rodzaju płatności jest odwzorowaniem regulacji europejskich ${ }^{53}$. Z uwagi na powszechność płatności bezpośrednich jako mechanizmu wsparcia rolnictwa pozyskiwane w ten sposób środki wpływają na konkurencyjność sektora rolnego.

\subsubsection{Akty wykonawcze}

W kształtowaniu konkurencyjności polskiego rolnictwa oraz określaniu instrumentów prawnych wpływających na konkurencyjność duże znaczenia mają akty wykonawcze o statusie rozporządzeń wydanych na mocy ustawy. Szczególnego znaczenia nabierają rozporządzenia określające warunki uzyskania pomocy na poszczególne działania PROW 2014-2020. Duża część z nich jest analizowana szczegółowo w rozdziale czwartym przy omawianiu poszczególnych instrumentów prawnych. Rozporządzeń tych jest ponad sto ${ }^{54}$. Ich omawianie znacznie wykroczyłoby poza cele stawiane w pracy.

52 Ustawa z dnia 5 lutego 2015 r. o płatnościach w ramach systemów wsparcia bezpośredniego (Dz. U. z 2018 poz. 1312 z późn. zm.).

53 J. Bieluk, D. Łobos-Kotowska, Płatności bezpośrednie, [w:] Prawo rolne, P. Czechowski (red.), Warszawa 2015, s. 410-423.

54 Dla przykładu można podać rozporządzenie Ministra Rolnictwa i Rozwoju Wsi z dnia 1 marca 2019 r. w sprawie szczegółowych warunków i trybu przyznawania oraz wypłaty pomocy finansowej na 
Określają one kryteria dostępu oraz szczegółowe elementy wniosku o przyznanie pomocy, a także o przyznanie płatności. W praktyce to od ich postanowień zależy kształt i skuteczność poszczególnych instrumentów prawnych.

Ponadto, istnieje wiele rozporządzeń horyzontalnych dotyczących PROW. Obejmują one swoim zakresem części wspólne dotyczące wszystkich instrumentów prawnych z polityki rozwoju obszarów wiejskich. Duża ich część ma tylko charakter proceduralny ${ }^{55}$, czy też finansowy ${ }^{56}$.

Rozporządzenia stanowią ważny materiał badawczy w procesie stosowania poszczególnych instrumentów prawnych. Pojawiające się problemy dotyczą zazwyczaj niewłaściwego wykonania dyspozycji ustawowej, czy niezgodności niektórych postanowień rozporządzeń z aktami wyższego rzędu. Tego typu sytuacje występują, co prawda rzadko, ale wpływają na konkurencyjność rolnictwa, tworząc niepewność prawa.

\subsubsection{Akty o charakterze quasi prawnym}

W systemie prawa polskiego dostrzeżono w prawie rolnym także akty prawne nie znajdujące się w katalogu źródeł prawa, ale mające wpływ na jego stosowanie.

Wiele zainteresowania budzi pozycja prawna PROW. W latach 2007-2013 był on wprowadzony do systemu prawa polskiego poprzez obwieszczenie Ministra Rolnictwa i Rozwoju Wsi ${ }^{57}$. Taka pozycja w hierarchii źródeł prawa w Polsce nie obowiązuje

operacje typu „Inwestycje odtwarzające potencjał produkcji rolnej” w ramach poddziałania „Wsparcie inwestycji w odtwarzanie gruntów rolnych i przywracanie potencjału produkcji rolnej zniszczonego w wyniku klęsk żywiołowych, niekorzystnych zjawisk klimatycznych i katastrof" objętego Programem Rozwoju Obszarów Wiejskich na lata 2014-2020 (Dz. U. poz. 431); rozporządzenie Ministra Rolnictwa i Rozwoju Wsi z dnia 23 października 2015 r. w sprawie szczegółowych warunków i trybu przyznawania oraz wypłaty pomocy finansowej na operacje typu „Rozwój przedsiębiorczości - rozwój usług rolniczych” w ramach poddziałania „Wsparcie inwestycji w tworzenie i rozwój działalności pozarolniczej” objętego Programem Rozwoju Obszarów Wiejskich na lata 2014-2020 (Dz. U. poz. 1843).

55 Przykładowo: rozporządzenie Ministra Rolnictwa i Rozwoju Wsi z dnia 24 marca 2015 r. w sprawie warunków, jakie powinny spełniać jednostki organizacyjne, którym agencja płatnicza może powierzyć wykonywanie czynności kontrolnych w ramach Programu Rozwoju Obszarów Wiejskich na lata 2014-2020 (Dz. U. poz. 473); rozporządzenie Ministra Rolnictwa i Rozwoju Wsi z dnia 13 sierpnia 2015 r. w sprawie danych niezbędnych do właściwego monitorowania realizacji i ewaluacji Programu Rozwoju Obszarów Wiejskich na lata 2014-2020 (Dz. U. poz. 1397); rozporządzenie Ministra Rolnictwa i Rozwoju Wsi z dnia 21 sierpnia 2015 r. w sprawie warunków i trybu przeprowadzania czynności kontrolnych w ramach Programu Rozwoju Obszarów Wiejskich na lata 2014-2020 (Dz. U. poz. 1344).

56 Por. rozporząazzenie Rady Ministrów z dnia 14 września 2015 r. w sprawie pożyczek z budżetu państwa na wyprzedzające finansowanie w ramach Programu Rozwoju Obszarów Wiejskich na lata 2014-2020 (Dz. U. poz. 1558); rozporządzenie Ministra Rolnictwa i Rozwoju Wsi z dnia 3 listopada 2015 r. w sprawie zaliczek w ramach Programu Rozwoju Obszarów Wiejskich na lata 2014-2020 (Dz. U. poz. 1857).

57 Obwieszczenie Ministra Rolnictwa i Rozwoju Wsi z dnia 12 października 2007 r. w sprawie Programu Rozwoju Obszarów Wiejskich na lata 2007-2013 (M.P. poz. 1035 z późn. zm.). 
i była kontestowana w nauce polskiej ${ }^{58}$ oraz w orzecznictwie ${ }^{59}$. Aktualny PROW na lata 2014-2020 został wprowadzony do systemu prawa polskiego zgodnie z procedurą opisaną w rozporządzeniu 1305/2013. W czerwcu 2015 r. ukazał się Komunikat Ministra Rolnictwa i Rozwoju Wsi o zatwierdzeniu przez Komisję Europejską Programu Rozwoju Obszarów Wiejskich na lata 2014-202060. Również takie umiejscowienie tak kluczowego dokumentu budzi wątpliwości wśród znawców problemu ${ }^{61}$. Należy postulować de lege ferenda inne zakotwiczenie PROW w polskim systemie prawa. Rodzi to przede wszystkim problemy, gdy dochodzi do niezgodności pomiędzy PROW a postanowieniami ustawy, czy rozporządzeń wykonawczych. Taki stan prawny w istotny sposób wpływa na treść instrumentów prawnych oddziałujących na konkurencyjność rolnictwa.

Kolejnym przykładem są uchwały dotyczące różnych programów rządowych, czy dokumentów koncepcyjnych. Takim przykładem może być uchwała nr 163 Rady Ministrów z dnia 25 kwietnia 2012 r. w sprawie przyjęcia „Strategii zrównoważonego rozwoju wsi, rolnictwa i rybactwa" na lata 2012-202062. Uchwała jako akt prawny nie znajduje się w konstytucyjnym katalogu źródeł prawa. Jednocześnie przywoływana strategia jest podstawą podejmowania decyzji związanych z wdrażaniem poszczególnych instrumentów prawnych.

Osobnym elementem dokumentów, które wpływają na konkurencyjność są różnego rodzaju wytyczne i instrukcje dla beneficjentów pomocy ${ }^{63}$. Są to dokumenty z którymi rolnik styka się w pierwszej kolejności. Z nich czerpie zazwyczaj całą swoją wiedzę o danym instrumencie prawnym. Dlatego też tak ważna jest $w$ tych broszurach precyzja słowa i ich zgodność z prawem. Jeżeli tego typu dokumenty będą odzwierciedlać postanowienia prawa są one czynnikiem pozytywnie wpływającym na konkurencyjność. Jednakże kiedy się zdarzy błąd w zakresie interpretacji postanowień ustawowych i tych przekazanych w broszurze, to fakt ten będzie negatywnie oddziaływał na efektywność danego mechanizmu prawnego.

58 P. Wojciechowski, Charakter prawny Programu Rozwoju Obszarów Wiejskich, [w:] Prawo rolne, P. Czechowski (red.), Warszawa 2017.

59 Wyrok TS UE z dnia 4 czerwca 2009 r. w sprawie C-241/07.

60 Komunikat Ministra Rolnictwa i Rozwoju Wsi z dnia 17 czerwca 2015 r. zatwierdzeniu przez Komisję Europejską Programu Rozwoju Obszarów Wiejskich na lata 2014-2020 (M.P. poz. 541).

61 P. Litwiniuk, Program Rozwoju Obszarów Wiejskich jako dokument programowy i źródło prawa rolnego, Warszawa 2018.

62 Uchwała nr 163 Rady Ministrów z dnia 25 kwietnia 2012 r. w sprawie przyjęcia „Strategii zrównoważonego rozwoju wsi, rolnictwa i rybactwa" na lata 2012-2020 (M.P. poz. 839).

63 Por. przykładowo broszurę dotyczącą płatności bezpośrednich, https://www.arimr.gov.pl/fileadmin/pliki/PB_2019/Kampania_2019/zalaczniki/ARiMR_Broszura_Platnosci_bezposrednie_w_2019. pdf [data dostępu 30 marca 2019 r.]. 


\subsection{Podsumowanie}

Zaprezentowane akty prawne europejskie i krajowe dotyczące celów WPR oraz instrumentów prawnych, mających powodować wzrost konkurencyjności rolnictwa, są zróżnicowane. Można wśród nich znaleźć zarówno regulacje traktatowe i konstytucyjne, ustawowe i rozporządzenia europejskie, jak i rezolucje Parlamentu Europejskiego, czy obwieszczenia Ministra Rolnictwa i Rozwoju Wsi. Powyższa analiza wykazała, że instrumenty prawne dotyczące konkurencyjności w rolnictwie stanowią część systemu prawa europejskiego i krajowego.

Każdy z tych instrumentów badany osobno, bez jego umiejscowienia w innych aktach prawnych, może okazać się nieskuteczny. Dlatego też ocenę efektywności danego mechanizmu prawnego, mającego poprawić konkurencyjność rolnictwa, należy czynić w szerszym kontekście. Różnorakie zakotwiczenie legislacyjne poszczególnych instrumentów prawnych nastręcza jednakże trudności w wykładni przepisów. Może się zdarzyć, że określone w rozporządzeniu europejskim mechanizmy zostaną niewłaściwie określone w PROW, a później w rozporządzeniach krajowych wykonawczych. Tego typu sytuacja zdarza się szczególnie często, gdy dochodzi do problemów z odpowiednim zrozumieniem przedstawianych pojęć oraz ich thumaczeniem językowym ${ }^{64}$.

Ponadto, przeprowadzona analiza udowodniła, że w kolejnych aktach prawnych następuje dopasowanie odpowiednich instrumentów prawnych do określonych celów WPR. Przy niezmienności tych ostatnich dobór poszczególnych instrumentów podyktowany jest aktualnym politycznym kształtem polityki rolnej oraz możliwościami finansowania poszczególnych mechanizmów. To dostosowanie w dłuższej perspektywie nie sprzyja rolnikom z uwagi na zmienność zasad przyznawania pomocy i zmienność przepisów. Planowanie działalności rolniczej podzielone na kolejne okresy

$64 \mathrm{O}$ problemach tłumaczenia aktów prawnych por. m.in. A. Jopek-Bosiacka, Przekad prawny i sądowy, Warszawa 2008; B. Kielar, Zarys translatoryki, Warszawa 2003, s. 28; D. Kierzkowska, Ttumaczenia prawnicze, Warszawa 2002, rozdz. 2 i nast.; A. Neubert, Textlinguistics of Translation, The textual Approach to Translation, Birmingham 1996, s. 101; J.S. Holmes, Translation theory, translation theories, translation studies, and the translator, [w:] Translated! Papers on Literary Translation and Translation Studies, J.S. Holmes (red.), Amsterdam 1998, s. 93-98; S.J. Schmidt, Texttheorie. Probleme einer Linguistik der sprachlichen Kommunikation, München 1976, s. 145; K. Reiss, H.J. Vermeer, Grundlegung einer allgemeinen Translationstheorie, Tübingen 1984; B.Z. Kielar, Language of the Law in the Aspect of Translation, Warszawa 1977; S. Šarčević, The new approach to legal translation, The Hague 2000; J.E. Joseph, Indeterminacy, Translation and the Law, [w:] Translation and the Law, M. Morris (red.), Amsterdam/Philadelphia 1995, s. 15-35; A. Matulewska, K. Gortych, Translacyjne problemy wyrażania modalności denotycznej $w$ tekstach aktów normatywnych $w$ języku polskim, angielskim i greckim, [w:] Prawo i język, A. Mróz, A. Niewiadomski, M. Pawelec (red.), Warszawa 2009, s. 65-78; A. Matulewska, Problemy przekładu terminologii wieloznacznej wystęującej w polskich tekstach aktów normatywnych, [w:] Prawo i język, A. Mróz, A. Niewiadomski, M. Pawelec (red.), Warszawa 2009, s. 85-94. 
finansowania nie sprzyja inwestowaniu długoterminowemu w rolnictwo, a co za tym idzie nie zachęca do prowadzenia działalności rolniczej.

Zaprezentowane akty prawne przedstawiają nie tylko różnorodność instrumentów prawnych oraz ich współzależność, ale także dość duży stopień skomplikowania legislacyjnego. Rolnik bez pomocy prawników, doradców, czy też odpowiednich instrukcji może się zniechęcić do korzystania z oferowanej pomocy finansowej. Już obecnie w Polsce duża część rolników nie korzysta z tych środków. Oznacza to, że nie tylko nie wpłyną one na poprawę konkurencyjności rolnictwa, ale skomplikowane prawo może spowodować w tym zakresie regres. Należy postulować de lege ferenda wypracowanie takich instrumentów prawnych, które za pomocą dość ograniczonej liczby wymogów dla rolnika, będą w stanie zachęcić go do skorzystania z nich.

Dokonana analiza źródeł prawa wpływających na konkurencyjność rolnictwa wskazała także na wzrastające znaczenie aktów prawnych o charakterze soft law. To te „miękkie” zalecenia formułowane na szczeblu europejskim w dość znaczny sposób oddziałują na kształt chociażby obrotu nieruchomościami rolnymi w poszczególnych państwach członkowskich. $Z$ jednej strony zapewnia to autonomię tych państw w kształtowaniu stosunków własnościowych nieruchomości rolnych. $Z$ drugiej jednakże tworzy niebezpieczny precedens przyznawania quasi prawotwórczej roli tych przepisów. 


\section{Rozdział 4}

\section{Instrumenty prawne Wspólnej Polityki Rolnej wpływające na konkurencyjność rolnictwa}

Sygnalizowane w poprzednich rozdziałach instrumenty prawne WPR wpływające na konkurencyjność rolnictwa mają swoje różne źródła. Bardzo duża część z nich służy realizacji polityki rozwoju obszarów wiejskich. Należą do nich zarówno instrumenty o charakterze inwestycyjnym, społecznym, jak i środowiskowo-klimatycznym. Każdy z nich ma wypełnić inną rolę. Jednocześnie wszystkie razem mają przyczynić się do ogólnej poprawy dochodowości gospodarstw rolnych, a co za tym idzie zwiększenia ich konkurencyjności.

Trzeba jednakże zwrócić uwagę, że efekty niektórych z tych instrumentów nie będą bezpośrednio oddziaływały na gospodarkę, a z pewnością nie będą zauważalne w krótkiej perspektywie czasu. Dotyczy to przede wszystkim instrumentów społecznych, czy tych związanych ze środowiskiem i klimatem. Na działanie tych instrumentów trzeba będzie poczekać co najmniej kilkanaście lat. Tak długa perspektywa w dość szybko zmieniającym się świecie i warunkach gospodarczych zaburza badania ekonomiczne, ale także i prawne. Legislatorzy, kształtując instrumenty na bieżący okres programowania, muszą mieć w pamięci perspektywę ich oddziaływania w szerszym zakresie. Przykładowo, nie istniejące już renty strukturalne nadal funkcjonują z uwagi na krąg beneficjentów i około dziesięcioletnie okresy ich pobierania. Dlatego też na każdy z tych instrumentów prawnych trzeba patrzeć nie tylko poprzez pryzmat aktualnej potrzeby, ale oceniać jego skuteczność w dłuższej perspektywie.

Analizie poddane zostaną także instrumenty prawne WPR, które funkcjonują na jednolitym rynku europejskim. Oddziałują one przede wszystkim na obrót produktami rolnymi wewnątrz UE. Są efektem ewolucji WPR i dołączania do wspólnego rynku kolejnych produktów rolnych. Duże znaczenie mają również mechanizmy prawne związane $\mathrm{z}$ handlem z państwami trzecimi. One w bezpośredni sposób wpływają na konkurencyjność eksporterów oraz produktów rolnych na rynkach obcych.

Trzeba także podkreślić na wzrastającą rolę instrumentów prawnych, które są określane w aktach typu soft law. Przykładem tutaj są unormowania europejskie dotyczące obrotu nieruchomościami rolnymi i zachowanie ich rolnego charakteru. Tego typu instrumenty będą zyskiwały na znaczeniu, a ich różna implementacja w kolejnych 
państwach członkowskich będzie skutkowała zróżnicowaniem tempa wzrostu konkurencyjności.

Ostatnim analizowanym elementem są instrumenty prawne stosowane w innych państwach europejskich. O ile na jednolitym rynku rolnym nie ma tutaj większych różnic, o tyle wybór odpowiednich mechanizmów z polityki rozwoju obszarów wiejskich może wpływać na konkurencyjność rolnictwa.

Poniższa analiza jest wyborem najważniejszych instrumentów prawnych. Sporządzony katalog nie wyczerpuje złożoności tematu i ma być tylko asumptem do rozwijania badań na pograniczu prawa i ekonomii w zakresie konkurencyjności rolnictwa.

\subsection{Instrumenty inwestycyjne}

Bardzo ważną rolę we wzroście konkurencyjności rolnictwa odgrywają instrumenty prawne, które są ukierunkowane na inwestycje. Pozwalają one przeznaczać fundusze europejskie na konkretny cel biznesowy. Można w tym zakresie rozliczyć taką inwestycję poprzez zaobserwowanie mierzalnych efektów ekonomicznych. Kupno nowego sprzętu rolniczego, budowa lub modernizacja budynków poprawiają możliwości gospodarcze prowadzenia działalności rolniczej, a przez to pozytywnie wpływają na jej dochodowość.

Przedstawione poniżej mechanizmy w dużej części to działania określone w PROW 2014-2020 jako te, które są odpowiednie dla polskiego rolnictwa. Ich wybór był determinowany wielkością przeznaczanych środków oraz popularnością wśród rolników.

\subsubsection{Inwestycje w środki trwałe}

Podstawowym instrumentem prawnym, mającym poprawić dochodowość gospodarstw rolnych jest działanie PROW 2014-2020 Inwestycje w środki trwałe1. Zgodnie z art. 17 rozporządzenia 1305/2013 inwestycje te mają poprawiać ogólne wyniki i zrównoważenie gospodarstwa rolnego. Ponadto, dotyczą przetwarzania, wprowadzania do obrotu lub rozwoju produktów rolnych objętych załącznikiem I do TFUE lub bawełny. Przede wszystkim dotyczą infrastruktury związanej z rozwojem, modernizacją lub dostosowaniem rolnictwa i leśnictwa, w tym dostępu do gruntów rolnych i leśnych, scalania i poprawy gruntów oraz dostaw i oszczędzania energii i wody. Obejmują one w tym zakresie inwestycje o charakterze materialnym i niematerialnym.

${ }_{1}$ Działanie to w części swojej konstrukcji odpowiada działaniu Modernizacja gospodarstw rolnych określonym w PROW 2007-2013. P. Cichalewska, S. Brodecki, Wpływ Programu Rozwoju Obszarów Wiejskich 2007-2013 na konkurencyjność polskiego rolnictwa, „Studia Iuridica Agraria”, Białystok 2012, t. 10, s. 355-365; P. Wojciechowski, A. Niewiadomski, Modernizacja gospodarstw rolnych, [w:] Prawo rolne, P. Czechowski (red.), Warszawa 2011, s. 432-433. 
Ponadto, w art. 17 ust. 1 lit. d rozporządzenia 1305/2013 powiązano inwestycje w ramach tego działania z inwestycjami nieprodukcyjnymi związanymi z osiąganiem celów rolno-środowiskowo-klimatycznych, realizowanych na mocy przepisów europejskich.

Zgodnie z art. 17 ust. 2 cytowanego rozporządzenia w przypadku inwestycji wspierających restrukturyzację gospodarstw państwa członkowskie ukierunkowują wsparcie dla gospodarstw zgodnie z analizą SWOT, przeprowadzoną w odniesieniu do unijnego priorytetu rozwoju obszarów wiejskich ,zwiększenie rentowności gospodarstw i konkurencyjności wszystkich rodzajów rolnictwa we wszystkich regionach oraz promowanie innowacyjnych technologii w gospodarstwach rolnych i zrównoważonego zarządzania lasami”. Oznacza to, że działanie „Inwestycje w środki trwałe" jest utożsamiane jako główne działanie, mające zwiększyć konkurencyjność rolnictwa.

Zgodnie z PROW 2014-2020 działanie „Inwestycje w środki trwałe” obejmuje następujące poddziałania:

- „Pomoc na inwestycje w gospodarstwach rolnych”,

- „Pomoc na inwestycje w przetwórstwo/marketing i rozwój produktów rolnych (przetwórstwo i marketing produktów rolnych)",

- „Scalanie gruntów”2.

Pierwsze z tych poddziałań jest podzielone na trzy typy operacji: „Modernizacja gospodarstw rolnych”, „Inwestycje w gospodarstwach położonych na obszarach Natura 2000” oraz „Inwestycje, mające na celu ochronę wód przed zanieczyszczeniami azotanami pochodzącymi ze źródeł rolniczych". Z punktu widzenia celów rozprawy największy zasięg oddziaływania i poziom wpływu na konkurencyjność ma ten pierwszy rodzaj operacji.

Zgodnie z PROW 2014-2020 celem instrumentu prawnego, jakim jest „Modernizacja gospodarstw rolnych" jest zwiększenie rentowności i konkurencyjności gospodarstw w następujących obszarach: rozwój produkcji prosiąt; rozwój produkcji mleka krowiego; rozwój produkcji bydła mięsnego; racjonalizacja technologii produkcji, wprowadzenie innowacji, zmiana profilu produkcji, zwiększenie skali produkcji, poprawa jakości produkcji lub zwiększenie wartości dodanej produktu4 4 Ponadto, znaczenia nabierają nawodnienia w gospodarstwie rolnym. Szczegółowe zasady przyznawania tej pomocy określa rozporządzenie Ministra Rolnictwa i Rozwoju Wsi z dnia 21 sierpnia 2015 r. w sprawie szczegółowych warunków i trybu przyznawania oraz wypłaty pomocy finansowej na operacje typu „Moderniza-

2 PROW 2014-2020 pkt 8.2.4.

3 P. Będźmirowska, Modernizacja gospodarstw rolnych, [w:] Prawo rolne, P. Czechowski (red.), Warszawa 2015, s. 432-434.

4 PROW 2014-2020 pkt 8.2.4.3.3.1. 
cja gospodarstw rolnych" objętego Programem Rozwoju Obszarów Wiejskich na lata $2014-2020^{5}$.

Zgodnie z PROW pomoc jest udzielana na materialne lub niematerialne inwestycje poprawiające ogólne wyniki (ogólną wydajność) gospodarstw rolnych, prowadzących zarobkową działalność rolniczą ${ }^{6}$. W ramach tego instrumentu wsparcia mogą być realizowane wyłącznie takie rodzaje operacji, które będą przyczyniały się do poprawy ogólnych wyników gospodarstwa. W PROW wskazano, że przez poprawę ogólnych wyników gospodarstwa rolnego rozumie się poprawę konkurencyjności i zwiększenie rentowności gospodarstwa rolnego w wyniku jego restrukturyzacji. Mierzalnym efektem tego instrumentu prawnego ma być doprowadzenie do wzrostu wartości dodanej brutto (GVA) w gospodarstwie, w szczególności w wyniku racjonalizacji technologii produkcji lub wprowadzenia innowacji, zmiany profilu lub skali produkcji, poprawy jakości produkcji lub zwiększenia wartości dodanej produktu, co najmniej o 10\% $\mathrm{w}$ odniesieniu do roku bazowego w okresie 5 lat od dnia przyznania pomocy ${ }^{7}$. Samo wyliczenie GVA oraz jego wykazanie w okresie 5 lat może okazać się trudne dla rolników.

Poprzez użycie tego instrumentu rolnik może uzyskać refundację części kosztów kwalifikowanych. Do najważniejszych z nich zalicza się koszty budowy lub modernizacji budynków lub budowli; koszty zakupu (w tym również instalacji) lub leasingu, zakończonego przeniesieniem prawa własności, nowych maszyn i wyposażenia do wartości rynkowej majątku; koszty zakupu (w tym również instalacji) lub budowy elementów infrastruktury technicznej; koszty zakładania sadów i plantacji krzewów owocowych owocujących efektywnie dłużej niż 5 lat; koszty zakupu lub rozwoju oprogramowania komputerowego i zakupu patentów, licencji, praw autorskich, znaków towarowych. Oznacza to ekonomiczną alokację zasobów w środki trwałe. Poprzez unowocześnienie sprzętu ma nastąpić podniesienie poziomu konkurencyjności oraz wydajności gospodarstw rolnych ${ }^{8}$.

Jednocześnie z pomocy tej mogą skorzystać rolnicy, którzy posiadają gospodarstwo rolne w rozumieniu Kodeksu cywilnego ${ }^{9}$, o powierzchni użytków rolnych co

5 Rozporządzenie Ministra Rolnictwa i Rozwoju Wsi z dnia 21 sierpnia 2015 r. w sprawie szczegółowych warunków i trybu przyznawania oraz wypłaty pomocy finansowej na operacje typu „Modernizacja gospodarstw rolnych" objętego Programem Rozwoju Obszarów Wiejskich na lata 2014-2020 (Dz. U. poz. 1371 z późn. zm.).

6 Przez prowadzenie działalności w celach zarobkowych rozumie się prowadzenie działalności, której podstawowym celem jest osiągnięcie dochodu. Prowadzenie działalności w celach naukowo-badawczych nie stanowi prowadzenia działalności w celach zarobkowych.

7 T. Kurowska, Założenia konstrukcyjne umowy przyznania pomocy z Europejskiego Funduszu Rolnego na rzecz Rozwoju Obszarów Wiejskich, „Studia Iuridica Agraria”, Białystok 2009, t. 7, s. 163-178.

8 B. Wieliczko, Mechanizmy oddziatywania funduszy strukturalnych na konkurencyjność polskiego rolnictwa, „Studia Iuridica Agraria”, Białystok 2012, t. 10, s. 443-457.

9 K. Stefańska, Pojęcia ,nieruchomość rolna” $i$,, gospodarstwo rolne” w ujęciu kodeksu cywilnego i ich znaczenie dla legislacji prawnorolnej, „Studia Iuridica Agraria”, Białystok 2009, t. 7, s. 93-103; 
najmniej 1 ha, i kierują tym gospodarstwem. Ponadto, wielkość ekonomiczna gospodarstwa uprawnionego do otrzymania pomocy stanowi co najmniej równowartość 13 tys. euro i nie jest większa niż 250 tys. euro. Jest to instrument wyraźnie skierowany do gospodarstw małych i średnich. Ten instrument dyskryminuje w wyraźny sposób gospodarstwa duże nastawione na produkcję wielkotowarową. Jest to jedna z kontrowersyjnych cech tego instrumentu prawnego. Powoduje ona nierówne traktowanie wszystkich rolników, co zakłóca konkurencję rynkową. Jednocześnie jako usprawiedliwienie takiego podejścia można znaleźć w przeorientowaniu całej polityki rolnej w Europie. Preferuje ona gospodarstwa rodzinne. Pozwala to jednocześnie oddziaływać na strukturę zaludniania na wsi i zachęcać rolników do pozostawania w swoich gospodarstwach.

Poziom udzielonej pomocy to $60 \%$ kosztów kwalifikowalnych operacji w przypadku młodych rolników i inwestycji zbiorowych, albo 50\% kosztów kwalifikowalnych w przypadku pozostałych operacji nie mniej niż 30\% kosztów kwalifikowalnych. Maksymalna wysokość pomocy udzielonej jednemu beneficjentowi i na jedno gospodarstwo rolne, w tym na realizację projektów zbiorowych, w ramach poddziałania, w okresie realizacji PROW 2014-2020, nie może przekroczyć: 900000 zł - w przypadku operacji realizowanej w ramach obszaru ${ }^{10}$.

Pozostałe operacje w ramach tego poddziałania obejmują także inwestycje w środki trwałe czy to na obszarach Natura 2000, czy na terenach OSN. Kierunek tego instrumentu jest dość jasny - refundować rolnikowi zakup środków trwałych, w zamian za co on musi wykazać wzrost wskaźnika GVA. Problemem jest refundacja. Oznacza to, że rolnik powinien najpierw wyłożyć własne środki lub też zgromadzić ich znaczną ilość na wkład własny, aby móc się starać o pomoc. Niepewność przyznania tej pomocy będzie zniechęcać rolników do inwestowania własnych pieniędzy. Będą oni woleli nadal pracować na starym sprzęcie, w niezmodernizowanych budynkach, ale z pewnością oczekiwanego zysku. Ryzyko w tym zakresie może się okazać dla nich zbyt duże. Dlatego też należy postulować de lege ferenda, aby ten instrument prawny zmodyfikować w kierunku dotacji, udzielanej przed zakupem środków lub promesy tej dotacji. Można również zintensyfikować działania na udzielanie niskooprocentowanych kredytów dla rolników chcących skorzystać z tego instrumentu.

„Modernizacja gospodarstw rolnych” jest tylko przykładem, w jaki sposób można ułatwiać dostęp do oferowanej pomocy, a co za tym idzie oddziaływać na konkurencyjność rolnictwa. Większa dostępność oferowanych środków finansowych będzie skutkowała większą ilością pieniędzy w gospodarce, a to przyczyni się do oczekiwanego wzrostu.

D. Kokoszka, Gospodarstwo rolne. Zagadnienia konstrukcyjne, „Kwartalnik Prawa Prywatnego”, 2008, nr 4, s. 985-1042.

10 PROW 2014-2020 pkt 8.2.4.3.3.11. 


\subsubsection{Wsparcie na przystępowanie do systemów jakości}

Jednym z nowych typów działań inwestycyjnych bazujących na projakościowych działaniach jest poddziałanie „Wsparcie na przystępowanie do systemów jakości”. Jest ono częścią działania „Systemy jakości produktów rolnych i środków spożywczych". Stanowi przykład nowego typu regulacji, które coraz większy nacisk kładą na bezpieczeństwo konsumenta i jakość żywności. Tego typu działania mają doprowadzić do wzrostu konkurencyjności rolnictwa.

Zgodnie z art. 16 ust. 1 rozporządzenia 1305/2013 wsparcie w ramach tego działania obejmuje nowe przystąpienie, lub przystąpienie w ostatnich pięciu latach, rolników i grup rolników do systemów jakości ustanowionych na mocy odrębnych przepisów europejskich. Ponadto, zakłada się przystąpienie rolników do systemów jakości, w tym systemów certyfikacji gospodarstw, produktów rolnych, bawełny lub środków spożywczych, uznanych przez państwa członkowskie za spełniające określone kryteria.

W ramach działania „Wsparcie na przystępowanie do systemów jakości” rolnik może otrzymać wsparcie, które ma charakter motywacyjny i ma na celu ułatwienie prowadzenia produkcji w nowych warunkach, wymaganych przez określony system jakości. Wsparcie ma na celu także umożliwienie pokrycia dodatkowych kosztów produkcji do momentu, kiedy będą one odzwierciedlone w wyższych cenach produktów na rynku ${ }^{11}$. Pomoc jest udzielana na podstawie rozporządzenia Ministra Rolnictwa i Rozwoju Wsi z dnia 6 sierpnia 2015 r. w sprawie szczegółowych warunków i trybu przyznawania wypłaty oraz zwrotu pomocy finansowej w ramach poddziałania „Wsparcie na przystępowanie do systemów jakości”12.

Beneficjentem programu może być tylko rolnik aktywny zawodowo ${ }^{13}$. Definicja rolnika aktywnego zawodowo została określona w art. 9 rozporządzenia 1307/2013. Wiąże to ten instrument prawny z płatnościami bezpośrednimi. Odpowiada również na postawioną hipotezę badawczą dotyczącą istnienia systemu przepisów prawnych, które łącznie wpływają na konkurencyjność rolnictwa. Przykład tego poddziałania jest tylko jedną z egzemplifikacji łączenia różnych instrumentów prawnych. Pociąga to za sobą konieczność stosowania wykładni systemowej prawa.

Koszty kwalifikowane obejmują koszty poniesione przy przystępowaniu do systemu jakości oraz roczną składkę za udział w tym systemie. Do kosztów kwalifikowalnych są zaliczane wydatki dotyczące kontroli zgodności z wymaganiami systemu. Beneficjent może otrzymać pomoc na poziomie do 2000 euro rocznie na gospodarstwo. Zasady udzielania pomocy preferują gospodarstwa o powierzchni od 5 do 10 ha

11 PROW 2014-2020 pkt 8.2.3.3.1.

12 Rozporządzenie Ministra Rolnictwa i Rozwoju Wsi z dnia 6 sierpnia 2015 r. w sprawie szczegółowych warunków i trybu przyznawania wypłaty oraz zwrotu pomocy finansowej w ramach poddziałania „Wsparcie na przystępowanie do systemów jakości” (Dz. U. poz. 1195 z późn. zm.).

13 P. Litwiniuk, Aktywny rolnik - nowy beneficjent wsparcia bezpośredniego w ramach WPR, ,Przegląd Prawa Rolnego", 2015, t. 16, nr 1, s. 211-228. 
użytków rolnych, które prowadzą wysokojakościową produkcję. Wymóg ten ponownie wskazuje, iż instrumenty wsparcia finansowego preferują gospodarstwa małe ${ }^{14}$, o charakterze rodzinnym.

Problemem tego instrumenty prawnego jest także brak możliwości pomiaru jego efektywności ${ }^{15}$. Trudno ocenić na ile udział w systemach jakości poprawi konkurencyjność rolnika. $Z$ pewnością uzyskanie certyfikatów, które mają przekonać konsumenta do odpowiedniej jakości będzie miało wpływ na sprzedaż takiego produktu rolnego. Trudno jest jednak zanalizować skalę tego wpływu. Instrument ten adresowany do bardzo wąskiej grupy beneficjentów ma dwojaki skutek. Po pierwsze, inwestycyjny. Stanowi on inwestycję w poprawę sposobu gospodarowania, pozyskiwania wiedzy i promocję produktu. Po drugie, stanowi element bezpieczeństwa produktów rolnych i żywnościowych poprzez zapewnienie odpowiedniego poziomu ich jakości.

\subsubsection{Wsparcie inwestycji związanych $\mathrm{z}$ tworzeniem, ulepszaniem lub rozbudową wszystkich rodzajów małej infrastruktury, w tym inwestycje w energię odnawialną i w oszczędzanie energii}

Jednym z działań o charakterze inwestycyjnym wykraczającym poza możliwości pojedynczego producenta rolnego jest działanie „Podstawowe usługi i odnowa wsi na obszarach wiejskich". Zgodnie z art. 20 ust. 1 rozporządzenia 1305/2013 wsparcie w ramach tego działania obejmuje w szczególności: sporządzanie i aktualizowanie planów rozwoju gmin i wsi na obszarach wiejskich i ich podstawowych usług oraz planów ochrony obszarów Natura 2000 i innych obszarów o wysokiej wartości przyrodniczej i planów zarządzania nimi; inwestycje związane z tworzeniem, ulepszaniem lub rozbudową wszystkich rodzajów małej infrastruktury, w tym inwestycje w energię odnawialną i w oszczędzanie energii. Ponadto, obejmuje ono inwestycje $\mathrm{w}$ infrastrukturę szerokopasmową ${ }^{16}, \mathrm{w}$ tym $\mathrm{w}$ jej tworzenie, ulepszanie i rozbudowę, pasywną infrastrukturę szerokopasmową oraz zapewnianie dostępu do łączności szerokopasmowej i rozwiązań z zakresu publicznej administracji; inwestycje w tworzenie, ulepszanie lub rozwijanie podstawowych usług lokalnych dla ludności wiejskiej, w tym rekreacji i kultury, oraz powiązanej infrastruktury; inwestycje w infrastrukturę rekreacyjną, informację turystyczną i infrastrukturę turystyczną o małej skali służącą publicznemu korzystaniu z tych usług ${ }^{17}$.

14 J. Stoksik, Formy pomocy unijnej dla matych gospodarstw rolnych w Polsce, „Zeszyty Prawnicze", 2016, nr 15, s. 205-229.

15 A. Kapała, Prawne determinanty polityki jakości produktów rolnych i środków spożywczych, „Studia Iuridica Lublinensia", 2017, t. 26, nr 1.

16 P. Wojciechowski, Infrastruktura telekomunikacyjna w rozwoju obszarów wiejskich, „Studia Iuridica Agraria", Białystok 2016, t. 14, s. 103-128.

17 Z. Wójcicki, Problemy modernizacji i rozwoju infrastruktury rolniczej i wiejskiej, „Infrastruktura i Ekologia Terenów Wiejskich", 2009, nr 4. 
$\mathrm{Z}$ tego działania można również finansować inwestycje w badania i inwestycje związane z utrzymaniem, odbudową i poprawą stanu dziedzictwa kulturowego i przyrodniczego wsi, krajobrazu wiejskiego i miejsc o wysokiej wartości przyrodniczej, w tym dotyczące powiązanych aspektów społeczno-gospodarczych oraz środków w zakresie świadomości środowiskowej; czy inwestycje ukierunkowane na przeniesienie działalności i przebudowę budynków lub innych obiektów położonych w osadach wiejskich lub w ich pobliżu, mające na celu poprawę jakości życia lub poprawę wyników osady w zakresie oddziaływania na środowisko.

W polskim PROW w ramach tego działania wskazano trzy poddziałania:

- „Wsparcie inwestycji związanych z tworzeniem, ulepszaniem lub rozbudową wszystkich rodzajów małej infrastruktury, w tym inwestycje w energię odnawialną i w oszczędzanie energii" - w jego ramach realizuje się operacje „Gospodarka wodno-ściekowa” oraz „Budowa i modernizacja dróg lokalnych”;

- „Wsparcie inwestycji w tworzenie, ulepszanie i rozwijanie podstawowych usług lokalnych dla ludności wiejskiej, w tym rekreacji i kultury, i powiązanej infrastruktury” - w jego ramach jest operacja „Ochrona zabytków i budownictwa tradycyjnego";

- „Wsparcie inwestycji w tworzenie, ulepszanie i rozwijanie podstawowych usług lokalnych dla ludności wiejskiej, w tym rekreacji i kultury, i powiązanej infrastruktury” - w jego ramach są operacje: „Inwestycje w obiekty pełniące funkcje kulturalne”, „Kształtowanie przestrzeni publicznej”, „Inwestycje w targowiska lub obiekty budowlane przeznaczone na cele promocji lokalnych produktów”.

Te trzy poddziałania wraz ze wskazanymi operacjami mają służyć rozwojowi otoczenia rolnictwa, a przez to także zwiększać jego konkurencyjność. Niewątpliwie budowa infrastruktury nie tylko ułatwia pracę rolnikowi, ale także pełni ważną rolę społeczną w zakresie kultury i dziedzictwa narodowego. Wszystkie wymienione instrumenty prawne są o charakterze inwestycyjnym. Przeznaczone są na zrealizowanie odpowiedniego projektu, który powinien służyć lokalnemu rolnictwu.

Jako przykład funkcjonowania tych instrumentów posłuży poddziałanie „Wsparcie inwestycji związanych z tworzeniem, ulepszaniem lub rozbudową wszystkich rodzajów małej infrastruktury, w tym inwestycje w energię odnawialną i w oszczędzanie energii"18 i operacje związane z budową i modernizacją dróg lokalnych. Szczegółowe zasady przyznawanej pomocy są regulowane w rozporządzeniu Ministra Rolnictwa i Rozwoju Wsi z dnia 4 września 2015 r. w sprawie szczegółowych warunków i trybu przyznawania oraz wypłaty pomocy finansowej na operacje typu „Budowa lub

18 Wyrok Wojewódzkiego Sądu Administracyjnego w Szczecinie z 16 kwietnia 2016 r., II SA/Sz 905/14; Por. także wyrok Wojewódzkiego Sądu Administracyjnego w Szczecinie z dnia 5 czerwca 2013 r. II SA/Sz 245/13, w którym wskazano, iż budowa urządzeń wytwarzających energię z odnawialnych źródeł energii stanowi budowę urządzeń infrastruktury technicznej; wyrok Naczelnego Sądu Administracyjnego z dnia 3 marca 2011 r., II OSK 2251/10. 
modernizacja dróg lokalnych” w ramach poddziałania „Wsparcie inwestycji związanych z tworzeniem, ulepszaniem lub rozbudową wszystkich rodzajów małej infrastruktury, w tym inwestycji w energię odnawialną i w oszczędzanie energii" objętego Programem Rozwoju Obszarów Wiejskich na lata 2014-202019.

Wsparcie w ramach tej operacji, jak sama nazwa wskazuje, obejmuje budowę lub modernizację dróg lokalnych i związanych z nimi urządzeń. Należy pamiętać, że działania te mają charakter niekomercyjny, ukierunkowany na zaspokajanie zbiorowych potrzeb wspólnot samorządowych ${ }^{20}$. Beneficjentami tego instrumentu prawnego mogą być gminy lub powiaty, a także ich związki²1. Wykluczono z tego mechanizmu samorząd wojewódzki. Nie znajduje to co prawda jakiegoś przekonującego uzasadnienia. De lege ferenda należałoby rozszerzyć ten mechanizm na wszystkie szczeble jednostek samorządu terytorialnego w Polsce.

Pomoc może być przyznana, jeśli operacja: jest realizowana w miejscowości należącej do: gminy wiejskiej lub gminy miejsko-wiejskiej, z wyłączeniem miast liczących powyżej 5 tys. mieszkańców, lub gminy miejskiej z wyłączeniem miejscowości liczących powyżej 5 tys. mieszkańców. Ponadto, operacja spełnia wymagania, wynikające $\mathrm{z}$ obowiązujących przepisów prawa, które mają zastosowanie do tej operacji oraz będzie realizowana na nieruchomości należącej do wnioskodawcy lub wnioskodawca posiada prawo do dysponowania nieruchomością na cele określone w operacji w czasie jej realizacji oraz przez okres związania celem. Operacja ma na celu połączenie jednostki osadniczej z istniejącą siecią drogową 22.

Problem, jaki można tutaj dostrzec, to wymaganie tytułu prawnego do dysponowania nieruchomością ${ }^{23}$. Oczywiście akt własności tutaj jest najlepszym rozwiązaniem. Jednakże budowa nowej drogi na gruntach, które tylko należą do gminny wydaje się aktualnie nierealna bez procedury wywłaszczenia ${ }^{24}$. Co prawda, droga publiczna jest

19 Rozporządzenie Ministra Rolnictwa i Rozwoju Wsi z dnia 4 września 2015 r. w sprawie szczegółowych warunków i trybu przyznawania oraz wypłaty pomocy finansowej na operacje typu „Budowa lub modernizacja dróg lokalnych” w ramach poddziałania „Wsparcie inwestycji związanych z tworzeniem, ulepszaniem lub rozbudową wszystkich rodzajów małej infrastruktury, w tym inwestycji w energię odnawialną i w oszczędzanie energii” objętego Programem Rozwoju Obszarów Wiejskich na lata 2014-2020 (Dz. U. poz. 1414 z późn. zm.).

20 PROW 2014-2020 pkt 8.2.7.2.

21 Przewiduje się preferencje dla operacji realizowanych na obszarach uboższych oraz charakteryzujących się wysokim wskaźnikiem bezrobocia, jak również operacje powiązane z inwestycjami dotyczącymi tworzenia infrastruktury szerokopasmowej. O wyborze operacji ponadto zdecydują uwarunkowania wynikające ze specyfiki regionu - PROW 2014-2020 pkt 8.2.7.3.1.7.

22 PROW 2014-2020 pkt 8.2.7.3.1.6.

${ }^{23}$ M. Hełdak, Zasady nabywania gruntów pod drogi publiczne w Polsce, ,Prace Naukowe Uniwersytetu Ekonomicznego we Wrocławiu", 2016, nr 418, s. 107-116.

24 M. Tomecki, Odpowiedzialność odszkodowawcza państwa z tytulu rozwoju infrastruktury drogowej, „Zeszyty Naukowe Uniwersytetu Ekonomicznego w Krakowie”, 2018, t. 975, nr 3, s. 145-157; A. Trembecka, Wplyw nieuregulowanych stanów prawnych nieruchomości na proces ustalania odszkodowań za nieruchomości wywtaszczone pod drogi, „Świat Nieruchomości”, 2017, nr 2, s. 23-30. 
celem publicznym zdefiniowanym w ustawie o gospodarce nieruchomościami, ale pojawia się problem aktów planistycznych i długotrwałych procedur $\mathrm{z}$ tym związanych. Ponadto, gmina musi przewidzieć słuszne odszkodowanie dla właściciela gruntu. Sprawy te zazwyczaj kończą się w sądzie i również wymagają czasu. Omawiana operacja oczywiście nie uznaje za koszt kwalifikowany odszkodowań związanych z wywłaszczeniem pod drogi publiczne ${ }^{25}$.

Problemem jest również dość wysoki wymóg udziału środków własnych gminy. Intensywność pomocy wynosi do $63,63 \%$ kosztów kwalifikowalnych operacji ${ }^{26}$. Wysokość pomocy ze środków EFRROW nie może przekroczyć 3000000 zł na beneficjenta w okresie realizacji Programu. Ponadto, wartość całkowitego kosztu operacji nie może przekroczyć dwukrotności wysokości pomocy ze środków EFRROW27. W aktualnych warunkach cenowych budownictwa w Polsce i dość dużym wzrostem cen na materiały budowlane, projektowanie 28 i wykonawstwo proponowane środki wydają się wystarczać na drobną modernizację małych dróg. Wydaje się, że mechanizm ten niezwykle atrakcyjny w założeniach i celach z uwagi na poziom finansowania może być niewłaściwie wykorzystywany.

De lege ferenda postuluje się pomoc publiczną dla gmin umożliwiającą znalezienie środków na wkład własny. Może nią być przykładowo udzielanie niskooprocentowanych kredytów na tę inwestycję. Bez tej pomocy na skorzystanie z tego instrumentu prawnego będzie stać tylko nieliczne gminy, które mają dość znaczne nadwyżki budżetowe ${ }^{29}$.

Analizowany mechanizm prawny jest przykładem potrzebnego instrumentu prawnego, który istotnie wpływa na konkurencyjność rolnictwa. Rozbudowana infrastruktura, a w szczególności drogi są warunkiem koniecznym dla rozwoju sektora rolnego. Dlatego też instrument ten należy utrzymać w przyszłej perspektywie uwzględniając zaproponowane zmiany ${ }^{30}$.

25 Za koszty kwalifikowane uznaje się: koszty budowy, przebudowy lub modernizacji obiektów budowlanych; koszty zakupu sprzętu, materiałów i usług, służących do realizacji operacji; koszty ogólne, bezpośrednio związane z przygotowaniem i realizacją operacji - PROW 2014-2020 pkt 8.2.7.3.1.5.

26 A. Stacherzak, M. Hełdak, J. Kazak, Obciązenia finansowe gmin kosztami realizacji dróg, „Prace Naukowe Uniwersytetu Ekonomicznego we Wrocławiu”, 2014, nr 331; K. Kozłowski, Finansowanie budowy dróg publicznych $w$ Polsce oraz wybrane prawne aspekty partnerstwa publiczno-prywatnego jako dodatkowej formy realizacji tych inwestycji, „Studia” BAS, 2017, nr 4, s. 143-164.

27 PROW 2014-2020 pkt 8.2.7.3.1.8.

28 W. Kozłowski, A. Surowiecki, Kierunki rozwoju konstrukcji nawierzchni dróg wiejskich, „Problemy Inżynierii Rolniczej”, 2011, nr 19, s. 173-183.

29 T. Miś, Przestrzenne zróżnicowanie wsparcia odnowy i rozwoju wsi z programów Unii Europejskiej, „Zagadnienia Doradztwa Rolniczego”, 2018, t. 93, nr 3, s. 5-19.

30 G. Trzciński, M. Pożyczka, K. Duk, Wpływ infrastruktury drogowej na zagospodarowanie obszarów wiejskich, „Studia i Materiały Centrum Edukacji Przyrodniczo-Leśnej”, 2016, nr 18. 


\subsection{Instrumenty o charakterze społecznym}

Ważnym czynnikiem rozwojowym jest dbałość o sprawy społeczne i walka z dyskryminacją i wykluczeniami. W polityce rolnej w Europie zbudowano w tym zakresie szereg instrumentów prawnych o różnej sile oddziaływania. Największa kategoria mechanizmów prawnych o charakterze społecznym, mająca wpływ na konkurencyjność rolnictwa, odnosi się do zmiany pokoleniowej na wsi ${ }^{31}$. Pomoc zarówno młodym rolnikom, jak i tym, którzy ze względu na wiek są zmuszeni zaprzestać prowadzenia działalności rolniczej wydaje się potrzebna. Oddziałuje ona przede wszystkim na sferę społeczną, zapewniając czy to pieniądze na rozpoczęcie działalności, czy to dofinansowanie możliwe do uzyskania po jej zaprzestaniu.

W PROW znajdują się instrumenty prawne zarówno mogące służyć ludziom młodym chcącym rozpocząć działalność rolniczą, jak i takie, które pomagają w podjęciu racjonalnej decyzji o jej zaprzestaniu. Instrumenty te czasami bywają ze sobą powiązane, co umożliwia pozostawanie większych środków w jednym gospodarstwie zamieszkiwanym przez dotychczasowego właściciela i jego następcę. Takie rozwiązania sprzyjają inwestycjom, a co za tym idzie oddziałują na konkurencyjność rolnictwa.

Ważnymi instrumentami społecznymi wpływającymi na funkcjonowanie rolnictwa są także dotacje związane $z$ edukacją i szeroko rozumianym doradztwem rolniczym. Poza spełnianiem waloru edukacyjnego, poprzez przepływ informacji pozwalają lepiej przygotowanym rolnikom konkurować na rynku.

Poniżej analizowane instrumenty prawne nie są tylko instrumentami o charakterze społecznym. Każde z nich, a przede wszystkim „Premie dla młodych rolników”, mają także walor inwestycyjny. $Z$ uwagi jednakże na przeważający cel poprawy struktury wiekowej producentów rolnych lub walor edukacyjny w rozprawie zaliczono je do instrumentów o charakterze społecznym. Jednoznaczna kwalifikacja tych instrumentów do danego rodzaju nie jest taka oczywista, ponieważ zawierają one oba komponenty: inwestycyjny i społeczny.

\subsubsection{Premia dla młodych rolników}

Działanie „Rozwój gospodarstw i działalności gospodarczej” jako jedno z poddziałań przewiduje „Pomoc w rozpoczęciu działalności gospodarczej na rzecz młodych rolników”32. Zgodnie z art. 19 ust. 1 rozporządzenia 1305/2013 wsparcie w ramach

31 R. Budzinowski, Formy prawne zmiany generacji inter vivos $w$ rolnictwie, [w:] Prawo rolne, P. Czechowski (red.), Warszawa 2011, s. 218-223; P. Blajer, Zmiana generacji w gospodarstwach rolnych $w$ Polsce w świetle polityki rozwoju obszarów wiejskich (aspekty prawne), „Przegląd Prawa Rolnego", 2010, t. 7, nr 2, s. 176 i nast.

32 Pozostałe poddziałania w tym działaniu to: „Pomoc na rozpoczęcie pozarolniczej działalności gospodarczej na obszarach wiejskich”; „Pomoc na rozpoczęcie działalności gospodarczej na rzecz rozwoju małych gospodarstw”; „Wsparcie inwestycji w tworzenie i rozwój działalności pozarolniczej”; „Płat- 
tego działania obejmuje pomoc na rozpoczęcie działalności gospodarczej na rzecz: młodych rolników ${ }^{33}$; działalności pozarolniczej na obszarach wiejskich; rozwoju małych gospodarstw. Ponadto, obejmuje inwestycje w tworzenie i rozwój działalności pozarolniczej oraz płatności roczne lub płatności jednorazowe dla rolników kwalifikujących się do systemu dla małych gospodarstw, którzy trwale przekazali swoje gospodarstwo rolne innemu rolnikowi.

Szczegółowe zasady przyznawania pomocy są uregulowane w rozporządzeniu Ministra Rolnictwa i Rozwoju Wsi z dnia 13 lipca 2015 r. w sprawie szczegółowych warunków i trybu przyznawania, wypłaty oraz zwrotu pomocy finansowej na operacje typu „Premie dla młodych rolników” w ramach poddziałania „Pomoc w rozpoczęciu działalności gospodarczej na rzecz młodych rolników” objętego Programem Rozwoju Obszarów Wiejskich na lata 2014-202034.

W PROW założono, że „Premie dla młodych rolników” przyczynią się do realizacji celu przekrojowego $\mathrm{w}$ zakresie innowacyjności dzięki skierowaniu wsparcia do młodych ludzi, którzy są bardziej skłonni do podejmowania ryzyka inwestycyjnego i wprowadzania innowacyjnych rozwiązań w gospodarstwie rolnym, związanych $\mathrm{z}$ organizacją produkcji, produktem oraz technologią produkcji ${ }^{35}$. Preferencje dla udziału młodych rolników w zorganizowanych formach współpracy producentów rolnych sprzyjają również wdrażaniu innowacyjnych rozwiązań ${ }^{36}$. Poddziałanie to ma zwiększyć konkurencyjność rolnictwa poprzez zmianę struktury zasobów pracy w rolnictwie na rzecz młodych rolników.

Pomoc w ramach operacji „Premii dla młodych rolników”, przyznaje się w związku z rozpoczynaniem prowadzenia gospodarstwa rolnego. Wsparcie dotyczy rozwoju działalności rolniczej w gospodarstwie rolnym, a także przygotowania do sprzedaży wytwarzanych w gospodarstwie produktów rolnych. Premię otrzymuje młody rolnik, czyli osoba, która ma nie więcej niż 40 lat, posiada odpowiednie kwalifikacje zawodowe ${ }^{37}$ oraz po raz pierwszy rozpoczyna prowadzenie działalności w gospodar-

ności na rzecz rolników kwalifikujących się do systemu małych gospodarstw, którzy trwale przekazali swoje gospodarstwo rolne innemu rolnikowi”.

33 M. Adamowicz, A. Szepeluk, Wsparcie młodych rolników jako element polityki rolnej Unii Europejskiej, „Zagadnienia Ekonomiki Rolnej”, 2016, t. 348, nr 3, s. 106-128.

34 Rozporządzenie Ministra Rolnictwa i Rozwoju Wsi z dnia 13 lipca 2015 r. w sprawie szczegółowych warunków i trybu przyznawania, wypłaty oraz zwrotu pomocy finansowej na operacje typu „Premie dla młodych rolników” w ramach poddziałania „Pomoc w rozpoczęciu działalności gospodarczej na rzecz młodych rolników" objętego Programem Rozwoju Obszarów Wiejskich na lata 2014-2020 (Dz. U. z 2018 r. poz. 759 z późn. zm.).

35 A. Kozłowski, K. Żok, Premie dla młodych rolników w PROW 2014-2020 - ocena naborów wniosków z lat 2015-2017, „Zagadnienia Doradztwa Rolniczego”, 2018, t. 91, nr 1, s. 16-31.

36 PROW 2014-2020 pkt 8.2.6.2.

37 Warunek dotyczący kwalifikacji zawodowych jest spełniony, jeżeli młody rolnik posiada kwalifikacje rolnicze, potwierdzone odpowiednim świadectwem lub dyplomem, lub odpowiedni staż pracy w rolnictwie, lub uzupełni kwalifikacje zawodowe (wykształcenie) w okresie 36 miesięcy od dnia doręczenia decyzji o przyznaniu pomocy. 
stwie rolnym jako jedyny kierujący gospodarstwem ${ }^{38}$. Oznacza to, że instrument ten premiuje nie tylko ludzi młodych, ale także takich, którzy posiadają odpowiednie kwalifikacje. Zmierza to do profesjonalizacji zawodu rolnika. Niewątpliwie z punktu założeń ekonomicznych prowadzenia działalności rolniczej przez podmioty do tego przygotowane będzie zwiększało to szanse na wzrost konkurencyjności.

Zgodnie z PROW osoba ubiegająca się o przyznanie pomocy powinna rozpocząć działalność w gospodarstwie rolnym przed dniem złożenia wniosku o przyznanie pomocy, lecz nie wcześniej niż w okresie 24 miesięcy przed jego złożeniem ${ }^{39}$. W tym miejscu należy zauważyć pewien problem związany z rozpoczynaniem działalności. Młoda osoba powinna ją rozpocząć zanim złoży wniosek. Oznacza to, że powinna zainwestować własne środki w rozpoczęcie działalności i liczyć na pozytywne rozpatrzenie jej wniosku w ramach omawianego poddziałania. Takie podejście skutecznie może zniechęcić młodych rolników do podejmowania działalności rolniczej i ubiegania się o tę pomoc. Ryzyko związane z utratą środków może okazać się zbyt duże. Jest to jeden z mankamentów tego instrumentu. De lege ferenda należałoby postulować zobowiązanie młodego rolnika do rozpoczęcia działalności już po otrzymaniu pomocy, albo wypłacenie jej w dniu zarejestrowania działalności.

Premia dla młodych rolników może być przyznana tylko raz, w okresie realizacji PROW 2014-2020, osobie i na gospodarstwo, tj. na grunty rolne, które wchodziły w skład gospodarstwa objętego pomocą, chyba że pomoc została przyznana, lecz nie została wypłacona $z$ powodu rezygnacji lub niespełnienia warunków wynikających z decyzji o przyznaniu pomocy ${ }^{40}$. Należy zaznaczyć, że wniosek o przyznanie tego rodzaju pomocy jest zakończony decyzją administracyjną. Pozwala to na

38 PROW 2014-2020 pkt 8.2.6.3.1.4.

39 Prowadzenie działalności w gospodarstwie rozpoczyna się co do zasady z dniem, gdy osoba ubiegająca się o przyznanie pomocy stała się właścicielem lub objęła w posiadanie gospodarstwo rolne o powierzchni co najmniej 1 ha użytków rolnych. W uzasadnionych przypadkach, gdy wystąpią okoliczności świadczące o tym, że mimo stania się właścicielem lub objęcia w posiadanie gospodarstwa, osoba ta nie prowadzi działalności w gospodarstwie, czynności w szczególności takie jak określono poniżej, mogą wyznaczyć późniejszą datę rozpoczęcia działalności w gospodarstwie: zgłoszenie zwierząt gospodarskich do rejestru w celu prowadzenia działalności rolniczej, wystąpienie o płatności bezpośrednie, wystąpienie o pomoc finansową dla rolników w ramach programów UE lub pomocy krajowej, prowadzenie działu specjalnego produkcji rolnej. Osoba ubiegająca się o przyznanie pomocy - przed dniem rozpoczęcia działalności w gospodarstwie nie dokonała żadnej z powyższych czynności - PROW 2014-2020 pkt 8.2.6.3.1.4.

40 PROW 2014-2020 pkt 8.2.6.3.1.4. Ponadto, premia nie może być przyznana osobie, której przyznano premię w ramach działania „Ułatwianie startu młodym rolnikom” PROW 2007-2013, ani na gospodarstwo, na które przyznano premię w ramach działania „Ułatwianie startu młodym rolnikom” PROW 2007-2013, ani na gospodarstwo, na które przyznano premię w ramach działania „Ułatwianie startu młodym rolnikom" PROW 2007-2013, chyba że pomoc została przyznana, lecz nie została wypłacona z powodu rezygnacji lub niespełnienia warunków wynikających z decyzji o przyznaniu pomocy. Por. A. Grontkowska, M. Frania, S. Bagieński, Ocena realizacji działania , ułatwianie startu młodym rolnikom” programu rozwoju obszarów wiejskich 2007-2013 wedlug województw, „Roczniki (Annals)”, 2016, nr 6 . 
uruchomienie drogi odwoławczej. Daje to zawsze większe szanse na zmianę decyzji, niż przyznawanie pomocy w drodze umowy (aczkolwiek i ona ma swoje niekwestionowane zalety).

Warunkiem uzyskania wsparcia jest również określenie powierzchni użytków rolnych w gospodarstwie, na którą jest udzielana pomoc na co najmniej średnią krajową, a w przypadku gospodarstw położonych w województwie o średniej niższej niż krajowa - równą co najmniej średniej wojewódzkiej, oraz nie większą niż 300 ha. Tego typu wymóg jest pewnym ewenementem w zakresie wspierania gospodarstw małych. Co prawda, średnia krajowa polskiego gospodarstwa rolnego nie jest imponująca, ale przyjęty mechanizm pozwala zastosować w miarę niedyskryminujące mierniki jako kryterium dostępu do pomocy. Pewne ograniczenie jest zawarte w wymogu, aby dotowane gospodarstwo miało wielkość ekonomiczną nie mniejszą niż 13 tys. euro i nie większą niż 150 tys. euro.

Beneficjent programu powinien przedstawić biznesplan i go realizować ${ }^{41}$. Efektem tego poddziałania powinno być uzyskanie wzrostu wielkości ekonomicznej gospodarstwa co najmniej o $10 \%$. Jest to jeden ze wskaźników, który pozwala ocenić w miarę rzetelnie wzrost konkurencyjności danego gospodarstwa. Jego spełnienie jest wymogiem koniecznym do rozliczenia pomocy.

Wymogiem stawianym w tym poddziałaniu jest także to aby beneficjent stał się rolnikiem aktywnym zawodowo najpóźniej w terminie 18 miesięcy od dnia doręczenia decyzji o przyznaniu pomocy. Ponadto, beneficjent zobowiązuje się do podlegania ubezpieczeniu społecznemu rolników na podstawie przepisów o ubezpieczeniu społecznym rolników jako rolnik z mocy ustawy i w pełnym zakresie przez okres co najmniej 12 miesięcy od dnia wypłaty pierwszej raty pomocy. W końcu beneficjent zobowiązuje się do prowadzenia działalności w gospodarstwie rolnym jako kierujący co najmniej do dnia upływu okresu związania celem. Kierujący gospodarstwem rolnym prowadzi działalność w gospodarstwie rolnym osobiście (pracuje w tym gospodarstwie i podejmuje wszelkie decyzje dotyczące gospodarstwa), na własny rachunek i we własnym imieniu, ponosi koszty i czerpie korzyści w związku z jego prowadzeniem $^{42}$. Spełnienie warunków wejściowych i końcowych umożliwia uzyskanie dotacji w wysokości 150 tys. zł.

Problemem jest również uniemożliwienie ubiegania się o pomoc przez jednego z małżonków, podczas gdy jeden z nich już tę pomoc otrzymał. $\mathrm{O}$ ile jest to uzasadnione, gdy prowadzą gospodarstwo rolne wspólnie, o tyle w sytuacji prowadzenia dwóch wyodrębnionych jednostek - gospodarstw rolnych wymóg ten powoduje nie-

41 Z programu są wyłączone gospodarstwa w zakresie chowu drobiu (nie dotyczy produkcji ekologicznej), prowadzenia plantacji roślin wieloletnich na cele energetyczne, prowadzenia niektórych działów specjalnych produkcji rolnej, w szczególności: hodowli zwierząt laboratoryjnych, hodowli ryb akwariowych, hodowli psów rasowych, hodowli kotów rasowych - PROW 2014-2020 pkt 8.2.6.3.1.6.

42 PROW 2014-2020 pkt 8.2.6.3.1.6. 
uzasadnioną dyskryminację jednego z małżonków ${ }^{43}$. W nauce prawa dostrzega się także inne bardziej złożone problemy prawne, związane $\mathrm{z}$ tym instrumentem przede wszystkim związane z kwalifikowaniem poszczególnych nieruchomości rolnych do obejmowania ich pomocą44.

Mankamentem tego poddziałania, który skutecznie zniechęca do ubiegania się o pomoc jest szereg warunków wstępnych, jak również nadzwyczajna ilość warunków wymaganych do rozliczenia działania ${ }^{45}$. Tego typu wymogi nie tylko powodują problemy prawne związane z ich interpretacją, ale skutecznie odstraszają potencjalnych zainteresowanych uzyskaniem pomocy. De lege ferenda należy już dziś sformułować postulat odpowiadający generalnemu uproszczeniu WPR. Analizowane poddziałanie jest doskonałym przykładałem jak dobrze pomyślany instrument ekonomiczny może zostać zaprzepaszczony poprzez stosowanie niewspółmiernych do wysokości udzielanej pomocy wymogów. W przypadku ich niespełnienia niebezpieczeństwo płacenia $\mathrm{kar}^{46}$, a co za tym idzie bankructwa młodego rolnika, skutecznie odstrasza od ubiegania się o tę pomoc. Nadmierność sankcji przy niespełnieniu chociażby jednego z wymogów może okazać się katastrofalna dla beneficjenta. Oznacza konieczność zwrotu całej otrzymanej dotacji. W większości przypadków młodych rolników nie będzie na to stać. Podobnie zresztą jak nie będą mieli możliwości finansowych skarżenia ARMiR przed sądem.

De lege ferenda zarówno w prawie krajowym, jak i europejskim trzeba postulować wyraźnie rozgraniczenie dotkliwości kar za niewykonanie poszczególnych wymogów ${ }^{47}$. Można je stosować chociażby w ujęciu proporcjonalnym do niewłaściwie wydatkowych środków. Przykładowo, gdy dotacja wynosiła 150 tys. zł, a ARMiR kwestionuje tylko $1500 \mathrm{zl}$ - to kara w tym przypadku mogłaby dotyczyć tego $1 \%$ niewłaściwie wydatkowanych środków. W przypadku gdy dotyczy ona całości dotacji powoduje najłagodniej określając, problemy finansowe młodego rolnika.

Instrument ten jest także przykładem na łączenie funkcji realizacji celów WPR. $Z$ jednej strony poprzez biznesplan, wymogi osiągnięcia ekonomicznych efektów jest to instrument inwestycyjny. Młody rolnik otrzymaną dotację powinien wydatkować zgodnie z przedstawionym biznesplanem. $Z$ drugiej strony $\mathrm{z}$ uwagi na zmianę pokoleniową w rolnictwie - preferencje dla osób z kwalifikacjami, które nie ukończyły

43 P. Litwiniuk, Z problematyki nadużycia prawa przez beneficjenta Wspólnej Polityki Rolnej, „Przegląd Prawa Rolnego", 2014, t. 15, nr 2, s. 45-63.

44 P. Litwiniuk, Program Rozwoju Obszarów Wiejskich jako dokument programowy i źródło prawa rolnego, Warszawa 2018, s. 86-90.

$45 \mathrm{~K}$. Giemza, Wdrażanie funduszy europejskich w polskim rolnictwie na przykładzie Programu Rozwoju Obszarów Wiejskich na lata 2014-2020, „Studia z Polityki Publicznej”, 2017, nr 15, s. 81-97.

46 B. Jeżyńska, Proporcjonalność sankcji $w$ działaniu PROW ,Utatwianie startu młodym rolnikom", [w:] Integracja europejska jako determinanta polityki wiejskiej. Aspekty prawne, P. Litwiniuk (red.), Warszawa 2017, s. 181-195 oraz judykatura tam cytowana.

47 P. Wojciechowski, Odpowiedzialność administracyjna i karna beneficjentów pomocy z Programu Rozwoju Obszarów Wiejskich, „Studia Iuridica Agraria”, Białystok 2012, t. 10, s. 281-306. 
40 roku życia można ten instrument prawny zakwalifikować do spełniania funkcji społecznej i kształtowania zasobów pracy w rolnictwie ${ }^{48}$.

Ponadto, należy również pamiętać, że uzyskanie statusu młodego rolnika wiąże się z możliwością uzyskiwania środków z innych instrumentów prawnych w ramach polityki rozwoju obszarów wiejskich, czy płatności bezpośrednich ${ }^{49}$. Powiązanie tych instrumentów skłania do stosowania wykładni systemowej prawa.

\subsubsection{Pomoc dla rolników zaprzestających prowadzenia działalności rolniczej}

Nie istnieje w aktualnym PROW działanie zbliżone do działania w PROW 2007-2013 „Renty strukturalne”, które pozwalało osobom, które ukończyły 55 lat na przekazanie swojego gospodarstwa odpowiednim podmiotom w zamian za rentę strukturalną ${ }^{50}$. Zasady przyznawania tej pomocy były uregulowane w rozporządzeniu Ministra Rolnictwa i Rozwoju Wsi z dnia 19 czerwca 2007 r. w sprawie szczegółowych warunków i trybu przyznawania pomocy finansowej w ramach działania „Renty strukturalne” objętego Programem Rozwoju Obszarów Wiejskich na lata 2007-201351. Połączone ono było także z działaniem „Ułatwianie startu młodym rolnikom”.

W poprzednim okresie programowania cieszyło się znaczną popularnością. Rolnik nie musiał przedstawiać żadnych biznesplanów. Otrzymywał dotację tylko ze względu na fakt trwałego zaprzestania prowadzenia działalności rolniczej. Niewątpliwie to działanie nie zwiększało bezpośrednio konkurencyjności poprzez system inwestycji, ale właśnie oddziaływało na sferę struktury wiekowej w polskim rolnictwie. Zdarzało się także, że przekazywane środki trafiały do rolnictwa w postaci inwestycji. Przykładowo, ojciec przekazując gospodarstwo synowi lub córce nadal pozostawał jako domownik w tym gospodarstwie i dokładał się do jego funkcjonowania ${ }^{52}$. Ocena

48 Por. Sprawozdanie specjalne Europejskiego Trybunału Obrachunkowego nr 10/2017 nt. Unijne wsparcie dla młodych rolników powinno być lepiej ukierunkowane. Tak aby zapewniało rzeczywisty wktad $w$ wymiane pokoleń (http://www.eca.europa.eu/Lists/ECA-Documents/SR17_10/SR_YOUNG_ FARMERS_PL.pdf [data dostępu 30 marca 2019 r.]; Opinia Europejskiego Komitetu EkonomicznoSpołecznego „W sprawie przyszłości młodych rolników w Europie” (Dz. U. UE C 2011 Nr 376, s. 19).

49 Por. https://www.gov.pl/web/rolnictwo/platnosc-dla-mlodych-rolnikow2 [data dostępu 30 marca 2019 r.].

50 B. Tańska-Hus, Renty strukturalne jako instrument poprawy struktury obszarowej rolnictwa i przyśpieszenia wymiany pokoleń, „Studia Iuridica Agraria”, Białystok 2012, t. 10, s. 404-423.

51 Rozporządzenie Ministra Rolnictwa i Rozwoju Wsi z dnia 19 czerwca 2007 r. w sprawie szczegółowych warunków i trybu przyznawania pomocy finansowej w ramach działania „Renty strukturalne” objętego Programem Rozwoju Obszarów Wiejskich na lata 2007-2013 (Dz. U. Nr 109 poz. 750 z późn. zm.).

52 M. Biczkowski, Instrumenty wspólnej polityki rolnej jako czynnik wspierajacy rozwój obszarów wiejskich. Studium na przykładzie regionu kujawsko-pomorskiego, Toruń 2018; M. Czekaj, Wybrane problemy sukcesji gospodarstw rolnych w Polsce, „Prace Naukowe Uniwersytetu Ekonomicznego we 
jednak skali tego zjawiska oraz próba analizy na ile środki z tego działania przyczyniły się do wzrostu konkurencyjności jest niemożliwa.

$Z$ tych też powodów w obecnym okresie programowania nie ma instrumentu prawnego, który byłby „kalką” albo kontynuacją rent strukturalnych ${ }^{53}$. Renty te nie spowodowały istotnych przemian strukturalnych $w$ rolnictwie ${ }^{54}$, a co za tym idzie wątpliwe jest czy spełniły cel podnoszenia konkurencyjności rolnictwa.

Pewnym odpowiednikiem tego działania, który mógłby spełniać podobną rolę jest wspomniane w poprzednim podrozdziale poddziałanie „Płatności na rzecz rolników kwalifikujących się do systemu małych gospodarstw, którzy trwale przekazali swoje gospodarstwo rolne innemu rolnikowi" 55 . Pomoc ta oczywiście nie jest ograniczona wiekowo i nie jest świadczeniem aż tak długoterminowym, jak renty strukturalne ${ }^{56}$. Jednakże starsi rolnicy mogą dostrzec w tym mechanizmie szansę (właściwie jedyną, jaką daje obecny PROW dla nich) na zyskanie dodatkowego finansowania w zamian za zakończenie prowadzenia działalności rolniczej.

Szczegółowe zasady przyznawania tej pomocy są uregulowane w rozporządzeniu Ministra Rolnictwa i Rozwoju Wsi z dnia 18 kwietnia 2016 r. w sprawie szczegółowych warunków o trybu przyznawania, wypłaty oraz zwrotu pomocy finansowej w ramach poddziałania „Płatności na rzecz rolników kwalifikujących się do systemu małych gospodarstw, którzy trwale przekazali swoje gospodarstwo rolne innemu rolnikowi” objętego Programem Rozwoju Obszarów Wiejskich na lata 2014-202057. Pomoc jest przyznawana tym rolnikom, którzy kwalifikują się do systemu dla małych gospodarstw ustanowionego w rozporządzeniu ws. płatności bezpośrednich i trwale przekazują swoje gospodarstwo rolne innemu rolnikowi ${ }^{58}$. Oznacza to pierwsze ograniczenie. Rolnik, który nie kwalifikuje się do systemu małych gospodarstw okre-

Wrocławiu", 2016, nr 439, s. 77-89; B. Wieliczko, Zmiany w WPR na lata 2014-2020 a modernizacja polskiej wsi i rolnictwa, „Journal of Agribusiness and Rural Development”, 2015, nr 3.

53 S. Kowalski, Oddziaływanie mechanizmów wspólnej polityki rolnej UE na przekształcenia strukturalne w polskim rolnictwie na przykładzie działania renty strukturalnej, ,Zarządzanie Finansami i Rachunkowość", 2015, nr 3, s. 31-44.

54 A. Mickiewicz, B. Mickiewicz, Charakterystyczne cechy nowego programu rozwoju obszarów wiejskich na lata 2014-2020, „Roczniki Naukowe Stowarzyszenia Ekonomistów Rolnictwa i Agrobiznesu", 2015, nr 17.

55 B. Jeżyńska, R. Pastuszko, Pakiet legislacyjny WPR 2014-2020 w świetle podstaw prawa UE i prawa międzynarodowego. Kompleksowa analiza prawna, Biuro Analiz i Dokumentów, OE - 186, marzec 2012.

56 E. Tomkiewicz, M. Bocheński, Polityka rozwoju obszarów wiejskich $w$ perspektywie lat 2014-2020 w kontekście nowych wyzwań, „Studia Iuridica Agraria”, Białystok 2012, t. 10, s. 239-250.

57 Rozporządzenie Ministra Rolnictwa i Rozwoju Wsi z dnia 18 kwietnia 2016 r. w sprawie szczegółowych warunków o trybu przyznawania, wypłaty oraz zwrotu pomocy finansowej w ramach poddziałania „Płatności na rzecz rolników kwalifikujących się do systemu małych gospodarstw, którzy trwale przekazali swoje gospodarstwo rolne innemu rolnikowi” objętego Programem Rozwoju Obszarów Wiejskich na lata 2014-2020 (Dz. U. poz. 598 z późn. zm.).

58 PROW 2014-2020 pkt 8.2.6.3.3.1. 
ślonych w rozporządzeniu 1307/2013 nie otrzyma wsparcia. Powoduje to znaczną dyskryminację, w szczególności rolników posiadających średnie dobrze prosperujące gospodarstwa.

Zgodnie z PROW pomoc może być przyznana rolnikowi, który w chwili składania wniosku o przyznanie pomocy kwalifikował się od przynajmniej jednego roku do uczestniczenia $\mathrm{w}$ systemie dla małych gospodarstw ${ }^{59}$, ustanowionym zgodnie $\mathrm{z}$ tytułem $\mathrm{V}$ rozporządzenia ws. płatności bezpośrednich, i który w drodze sprzedaży lub darowizny trwale przekaże swoje gospodarstwo rolne innemu rolnikowi ${ }^{60}$. Oznacza to konieczność trwałego wyzbycia się gospodarstwa rolnego na rzecz innego rolnika. Ponadto, po przekazaniu gospodarstwa beneficjent nie będzie podlegał ubezpieczeniu społecznemu rolników w Kasie Rolniczego Ubezpieczenia Społecznego.

W tym zakresie otrzymana roczna stawka pomocy, która odpowiada $120 \%$ rocznej płatności, do otrzymania której beneficjent kwalifikuje się w ramach systemu dla małych gospodarstw, może okazać się niewystarczająca. Wsparcie jest wypłacane $\mathrm{w}$ formie jednorazowej płatności od daty przekazania gospodarstwa rolnego do dnia 31 grudnia 2020 roku. Może się zdarzyć, że rolnik przekaże to gospodarstwo w formie darowizny na długo przed swoją emeryturą rolniczą. Jedynym jego środkiem utrzymania będzie wtedy ta jednorazowa płatność. Jest to duża wada tego instrumentu, która będzie zniechęcać starszych rolników do przekazywania swoich gospodarstw.

Analizowany instrument prawny jest z pogranicza instrumentów inwestycyjnych i społecznych. Z jednej strony prowadzi do poprawy struktury agrarnej, a nabywający rolnik inwestuje swoje pieniądze w gospodarstwo rolne. Prowadzi to do ukształtowania pożądanej wielkości gospodarstw, które na wolnym rynku powinny sprostać konkurencji nawet bez specjalnego wsparcia. $Z$ drugiej strony, gdyby ten instrument połączyć de lege ferenda z regulacjami dotyczącymi ubezpieczenia społecznego rolników cieszyłby się on większym zainteresowaniem rolników, którzy ze względu na wiek nie mogą już prowadzić swojej działalności. Zbliżyłby się wtedy w konstrukcji prawnej do rent strukturalnych. Byłby oczywiście znaczniej mniej atrakcyjny poprzez jednorazową dotację.

Założenia tego instrumentu prawnego $\mathrm{w}$ aktualnym kształcie nie przyniosą raczej spektakularnych efektów znacząco wpływających na konkurencyjność rolnictwa. Jed-

59 B. Mickiewicz, A. Mickiewicz, Problematyka matych gospodarstw rolnych $w$ rolnictwie polskim w latach 2014-2020 w świetle regulacji prawnych Parlamentu Europejskiego i Rady, „Problemy Drobnych Gospodarstw Rolnych", 2016, nr 1, s. 33-44; A. Chlebicka, J. Falkowski, T. Wołek, Małe gospodarstwa rolne - charakterystyka, Warszawa 2009; M. Dudzińska, K. Kocur-Bera, Definicja matego gospodarstwa rolnego, „Infrastruktura i Ekologia Terenów Wiejskich”, 2013, t. 4, nr 1, s. 17-30.

60 Gospodarstwo przejmujące grunty od beneficjenta musi posiadać lub osiągnąć, po przejęciu gruntów od beneficjenta działania, co najmniej wielkość odpowiadającą: średniej wielkości gospodarstwa w Polsce lub średniej wielkości gospodarstwa w danym województwie, jeśli średnia powierzchnia gospodarstw w danym województwie jest mniejsza niż średnia wielkość gospodarstwa w Polsce - PROW 2014-2020 pkt 8.2.6.3.3.6. 
norazowa roczna „premia” za zbycie gospodarstwa może okazać się niewystarczającą zachętą do zakończenia prowadzenia działalności rolniczej.

\subsubsection{Tworzenie grup producentów rolnych}

Instrumentem z pogranicza działań inwestycyjnych i społecznych jest działanie PROW „Tworzenie grup i organizacji producentów”. Zgodnie z art. 27 rozporządzenia 1305/2013 wsparcia w ramach tego działania udziela się w celu ułatwienia tworzenia grup i organizacji producentów w sektorach rolnictwa i leśnictwa do celów: dostosowania do wymogów rynkowych procesu produkcyjnego i produktów producentów, którzy są członkami takich grup lub organizacji; wspólnego wprowadzania towarów do obrotu, w tym przygotowania do sprzedaży, centralizacji sprzedaży i dostawy do odbiorców hurtowych. Ponadto, działanie to służy do celów ustanowienia wspólnych zasad dotyczących informacji o produkcji, ze szczególnym uwzględnieniem zbiorów i dostępności; oraz innych zadań, które mogą być prowadzone przez grupy i organizacje producentów, takich jak rozwijanie umiejętności biznesowych i marketingowych oraz organizowanie i ułatwianie procesów wprowadzania innowacji.

Działanie to sprzyja integracji rolników oraz tworzenia nowych form prowadzenia działalności rolniczej6 ${ }^{61}$. Zgodnie z przywołanym rozporządzeniem wsparcia udziela się grupom i organizacjom producentów, które zostały oficjalnie uznane przez właściwy organ państwa członkowskiego na podstawie planu biznesowego. Wsparcie to ogranicza się do grup i organizacji producentów, które są MŚP. Przedstawienie planu biznesowego dla grupy producentów rolnych może okazać się pewną zaporą, z uwagi na dość długi czas potrzebny do jego ustalenia, w przypadku gdy rolników jest więcej62. Ponadto, państwa członkowskie weryfikują, czy cele określone w planie biznesowym zostały osiągnięte $\mathrm{w}$ ciągu pięciu lat po uznaniu grupy lub organizacji producentów.

W PROW to działanie ma tylko jedno poddziałanie „Tworzenie grup i organizacji producentów w rolnictwie i leśnictwie”. Wsparcie stanowi procentowy ryczałt od wartości przychodów netto grupy lub organizacji producentów ze sprzedaży produktów lub grupy produktów, wytworzonych w gospodarstwach rolnych jej członków, w poszczególnych latach i sprzedanych odbiorcom niebędącym członkami grupy lub organizacji. Pomoc jest przyznawana w okresie pierwszych 5 lat funkcjonowania grupy/organizacji od dnia rejestracji/uznania ${ }^{63}$.

61 B. Jeżyńska, Organizacja rolniczej działalności wytwórczej w ramach klastra, „Studia Iuridica Agraria", 2011, t. 9, s. 257-270.

62 A. Suchoń, Grupy producentów rolnych jako instrument rozwoju agrologistyki, „Logistyka”, 2012, nr 4, s. 1258-1264.

63 PROW 2014-2020 pkt 8.2.9.3.1.2. 
Pomoc może być przyznana wnioskodawcy, który spełnia następujące warunki: grupa lub organizacja producentów została uznana ${ }^{64}$ na poziomie kraju na podstawie biznesplanu; łączy producentów jednego produktu lub grupy produktów, którzy nie byli członkami grupy producentów/wstępnie uznanej grupy producentów/ organizacji, utworzonej ze względu na ten sam produkt lub grupę produktów, której przyznano pomoc na rozpoczęcie działalności ze środków Unii Europejskiej po dniu 1 maja 2004 r. ${ }^{65}$. Ponadto, zgodnie z cytowanym powyżej rozporządzeniem, przedłoży biznesplan i zadeklaruje jego realizację w celu osiągnięcia jego założeń w trakcie trwania 5-letniego okresu wsparcia.

Szczegółowe zasady przyznawania pomocy zawarto w rozporządzeniu Ministra Rolnictwa i Rozwoju Wsi z dnia 2 sierpnia 2016 r. w sprawie szczegółowych warunków i trybu przyznawania, wypłaty oraz zwrotu pomocy finansowej w ramach działania „Tworzenie grup producentów rolnych i organizacji producentów objętego Programem Rozwoju Obszarów Wiejskich na lata 2014-2020”66. Zgodnie z PROW, przewiduje się preferencje w przyznawaniu pomocy dla grup i organizacji producentów, spełniających m.in. warunki zorganizowania w formie spółdzielni67. Może to rodzić zarzuty dotyczące nierównego traktowania podmiotów w tej samej sytuacji prawnej. Popierając ideę spółdzielczości w rolnictwie należy de lege ferenda rozważyć inne sposoby zachęt do tworzenia spółdzielni rolnych.

Wsparcie wynosi maksymalnie równowartość 100000 euro w każdym roku pięcioletniego okresu pomocy. Jest wypłacane procentowo przez pięć kolejnych lat.

Działanie to należy ocenić pozytywnie. Jednakże należy przedsięwziąć czynności informacyjne, aby zachęcić rolników do integracji i współpracy. Niewątpliwie nie jest

${ }^{64} \mathrm{~W}$ Polsce procedurę uznania reguluje ustawa z dnia 15 września 2000 r. o grupach producentów rolnych i ich związkach oraz o zmianie innych ustaw (Dz. U. z 2018 r. poz. 1026), a także w odniesieniu do branży mlecznej ustawa z dnia 20 kwietnia 2004 r. o organizacji rynku mleka i przetworów mlecznych (Dz. U. z 2018 r. poz. 724 z późn. zm.).

65 PROW 2014-2020 pkt 8.2.9.3.1.6.

66 Rozporządzenie Ministra Rolnictwa i Rozwoju Wsi z dnia 2 sierpnia 2016 r. w sprawie szczegółowych warunków i trybu przyznawania, wypłaty oraz zwrotu pomocy finansowej w ramach działania „Tworzenie grup producentów rolnych i organizacji producentów objętego Programem Rozwoju Obszarów Wiejskich na lata 2014-2020” (Dz. U. poz. 1284 z późn. zm.).

67 Ponadto, preferencje są dla grup zrzeszających producentów w następujących kategoriach: produkty wysokiej jakości objęte art. 16 rozporządzenia EFRROW, w szczególności rolnictwa ekologicznego; świnie żywe, prosięta, warchlaki, mięso wieprzowe: świeże, chłodzone, mrożone; bydło żywe: zwierzęta rzeźne lub hodowlane, mięso wołowe: świeże, chłodzone, mrożone; owce lub kozy żywe, zwierzęta rzeźne lub hodowlane, wełna owcza lub kozia strzyżona potna; mięso owcze lub kozie: świeże, chłodzone, mrożone, skóry owcze lub kozie surowe (suszone); miód naturalny lub jego produkty pszczele; rośliny w plonie głównym, całe lub rozdrobnione, uprawiane z przeznaczeniem na cele energetyczne lub do wykorzystania technicznego; szyszki chmielowe. Ponadto, grupy producentów zrzeszających jak największą liczbę członków w danej kategorii oraz zrzeszających producentów, w gospodarstwach, których produkcja została objęta dobrowolnym ubezpieczenie - PROW 2014-2020 pkt 8.2.9.3.1.7; por. także A. Suchoń, W kwestii nowego modelu spółdzielczości rolniczej, „Przegląd Prawa Rolnego”, 2013, t. 12 , nr 1 , s. $27-48$. 
to postulat ściśle prawny, ale wymaga on rozwagi. Trzeba także rozważyć, że potrzebnym jest tworzenie preferencji dla wybranych grup producentów rolnych. Tworzy to sztuczne podziały i hamuje wzrost konkurencyjności.

\subsubsection{Doradztwo rolnicze}

Jednym $z$ ważnych instrumentów prawnych i społecznych jest edukacja i pomoc doradcza ${ }^{68}$ dla rolników. Tylko przygotowany rolnik, który będzie posiadał odpowiednie informacje, będzie mógł skutecznie ubiegać się o pomoc, a co za tym idzie właściwie konkurować z innymi rolnikami. Służą temu wszelkie działania związane z doradztwem rolniczym. W tym zakresie w PROW 2014-2020 wprowadzono działanie „Usługi doradcze, usługi zarządzania gospodarstwem i usługi z zakresu zastępstw”.

Zgodnie z art. 15 ust. 1 rozporządzenia 1305/2013, wsparcia w ramach tego działania udziela się w celu udzielania pomocy rolnikom, młodym rolnikom, posiadaczom lasów, innym zarządcom gruntów i MŚP na obszarach wiejskich w korzystaniu z usług doradczych w celu poprawienia wyniku gospodarczego i wyników w zakresie oddziaływania na środowisko ich gospodarstw rolnych, przedsiębiorstw lub inwestycji, a także zwiększenia przyjazności tych gospodarstw, przedsiębiorstw lub inwestycji dla klimatu oraz ich odporności na zmianę klimatu. Ponadto, działanie to ma wspierać tworzenie usług z zakresu zarządzania gospodarstwem oraz usług z zakresu zastępstw i doradztwa w zakresie prowadzenia gospodarstwa, jak również usług doradczych w zakresie leśnictwa, w tym systemu doradztwa rolniczego ${ }^{69}$.

W ramach tego działania wyróżniono poddziałania: „Wsparcie korzystania z usług doradczych” oraz „Wsparcie dla szkolenia doradców”. Zasady przyznawania pomocy są regulowane przez rozporządzenia Ministra Rolnictwa i Rozwoju Wsi ${ }^{70}$. Programy te są skierowane co prawda do profesjonalistów świadczących usługi doradcze ${ }^{71}$, ale po ich wdrożeniu służą one rolnikom i umożliwiają pełne korzystanie z oferowanej pomocy.

68 B. Jeżyńska, Funkcje doradztwa rolniczego w europejskim partnerstwie innowacyjnym na rzecz wydajnego- i zrównoważonego rolnictwa EPI-AGRI, 2016, Opinie i Ekspertyzy, Kancelaria Senatu Biuro Analiz i Dokumentacji, Warszawa 2016.

69 A. Wiatrak, Doradztwo rolnicze w literaturze - stan badań krajowych i europejskich, [w:] Publiczne doradztwo rolnicze wobec wyzwań przyszłości i oczekiwań mieszkańców wsi, J. Kania, L. Leśniak (red.), Kraków 2013.

70 Rozporządzenie Ministra Rolnictwa i Rozwoju Wsi z dnia 22 marca 2017 r. w sprawie szczegółowych warunków przyznawania pomocy finansowej w ramach poddziałania „Wsparcie korzystania z usług doradczych" objętego Programem Rozwoju Obszarów Wiejskich na lata 2014-2020 oraz warunków i trybu jej wypłaty (Dz. U. poz. 692 z późn. zm.); rozporządzenie Ministra Rolnictwa i Rozwoju Wsi z dnia 21 marca 2017 r. w ramach poddziałania „Wsparcie dla szkolenia doradców” objętego Programem Rozwoju Obszarów Wiejskich na lata 2014-2020 oraz warunków i trybu jej wypłaty (Dz. U. poz. 642 z późn. zm.).

71 B. Jeżyńska, Wizja systemu doradztwa rolniczego w kontekście propozycji legislacyjnych Komisji Europejskiej, Warszawa 2012, BAS - 2405/12A. 
Pierwsze z tych poddziałań polega na udzieleniu pomocy finansowej podmiotom świadczącym usługi doradcze z zakresu zarządzania gospodarstwem, usługi z zakresu zastępstw, usługi doradcze $\mathrm{w}$ zakresie prowadzenia gospodarstwa lub usługi doradcze w zakresie leśnictwa. Beneficjentów wybiera się nie tylko w oparciu o przepisy przywołanych powyżej rozporządzeń, ale także na podstawie ustawy z dnia 29 stycznia 2004 r. Prawo zamówień publicznych ${ }^{72}$.

Doradztwo, z którego mogą skorzystać rolnicy, jest określone w rozporządzeniu wykonawczym Ministra dość szeroko. W $§ 4$ ust. 2 określono tylko jego najczęstsze przypadki, zaliczając do nich: wypełnienie wniosku o przyznanie płatności w ramach systemów wsparcia bezpośredniego; przygotowanie dokumentów do działań objętych Programem lub Programem Rozwoju Obszarów Wiejskich na lata 2007-2013; sporządzenie oceny gospodarstwa rolnego w zakresie spełniania wymogów wzajemnej zgodności (cross-compliance); opracowanie planu dostosowania gospodarstwa rolnego do wymogów wzajemnej zgodności (cross-compliance); sporządzenie planu nawożenia; opracowanie programu ochrony roślin; sporządzenie planu przestawienia gospodarstwa rolnego na produkcję metodami ekologicznymi. Katalog ten jest otwarty i można do niego dopisywać także inne rodzaje porad ${ }^{73}$. Takie rozwiązanie należy przyjąć z zadowoleniem, gdyż ułatwia ono reagowanie na bieżące potrzeby rolników, bez potrzeby zmiany aktu prawa powszechnie obowiązującego.

$\mathrm{W} \S 5$ ust. 1 pkt 4 lit. c omawianego rozporządzenia ponownie następuje uprzywilejowanie świadczenia pomocy na rzecz małych gospodarstw. Pomoc z tego poddziałania jest przyznawana na operację, która będzie realizowana zgodnie z ramowym programem doradczym, określającym planowaną liczbę odbiorców usług doradczych w odniesieniu do poszczególnych usług doradczych, jakie mogą być objęte operacją, będących: rolnikami, którzy nie ukończyli 40. roku życia; rolnikami prowadzącymi gospodarstwo rolne o powierzchni gruntów ornych, sadów, łąk trwałych, pastwisk trwałych, gruntów rolnych zabudowanych, gruntów pod stawami lub gruntów pod rowami do 5 ha; rolnikami prowadzącymi gospodarstwo rolne o powierzchni gruntów ornych, sadów, łąk trwałych, pastwisk trwałych, gruntów rolnych zabudowanych, gruntów pod stawami lub gruntów pod rowami powyżej 5 ha do 50 ha. Co prawda, w dalszych przepisach wspomina się także o rolnikach posiadających gospodarstwa powyżej 50 ha, ale wprowadzenie takiego rozróżnienia wyraźnie preferuje gospodarstwa małe.

Podobnie jak przy innych instrumentach prawnych tego typu rozwiązanie może spotkać się z dwojaką oceną. $Z$ jednej strony z zarzutem dyskryminacji dużych gospodarstw. $Z$ drugiej zaś strony z kierowaniem pomocy do najbardziej potrzebujących. Wyważenie pomiędzy tymi dwoma wartościami jest poza sferą prawa i wydaje się

72 Ustawa z dnia 29 stycznia 2004 r. Prawo zamówień publicznych (Dz. U. z 2017 r. poz. 1579 z późn. zm.).

73 E. Matuszak, Polskie doradztwo rolnicze wobec nowych wyzwań w ramach UE, „Zagadnienia Doradztwa Rolniczego", 2011, nr 1, s. 97-104. 
obecnie niezwykle trudne. De lege lata w stosowaniu tego przepisu należałoby położyć nacisk na powszechność doradztwa oraz na możliwość korzystania z niego również przez rolników posiadających więcej niż 50 ha.

Beneficjenci bezpośredni tego programu to głównie wojewódzkie ośrodki doradztwa rolniczego, izby rolnicze, prywatne podmioty doradcze ${ }^{74}$. Beneficjenci pośredni zaś to rolnicy, którym profesjonalna pomoc ułatwia nie tylko ubieganie się o środki finansowe przeznaczone na rolnictwo, ale także wpływa na ich pozycję konkurencyjną.

Instrument ten został zaliczony do instrumentów o charakterze społecznym ze względu na jego edukacyjny walor. Pozwala on wykształcić grupę profesjonalnych doradców rolniczych, którzy mogą służyć swoją wiedzą dłużej niż jeden okres finansowania. Jednocześnie służy rolnikom, którzy otrzymują odpowiednią pomoc, ale także edukację $e^{75} \mathrm{~W}$ zakresie wymaganych procedur, czy warunków uzyskiwania pomocy.

\subsection{Rola instrumentów prośrodowiskowych}

Poddana w rozdziale drugim analizie ewolucja WPR wskazuje na zmianę prymatu konkurencyjności rolnictwa, jako celu WPR. Od 2013 r. następuje wzmocnienie czynnika środowiskowego oraz klimatycznego. Są to nie tylko działania w ramach PROW, ale przede wszystkim stosowanie dość powszechnego instrumentu płatności bezpośrednich. Powstaje pytanie: czy wzrost konkurencyjności może iść w parze z ochroną środowiska?

W obecnym stanie prawnym na tak postawione pytanie należy odpowiedzieć pozytywnie. Konsumenci zaczynają zwracać uwagę nie tylko na cenę produktu, lecz także na jego jakość i wartości odżywcze. Związane jest to z bezpieczeństwem żywności. Dlatego też rolnictwo ekologiczne jako jeden z podstawowych instrumentów prawnych wpływa zarówno na konkurencyjność rolnictwa, jak na i środowisko. Wyważenie pomiędzy tymi celami będzie stanowiło nowe wyzwanie dla określenia ram WPR nie tylko w najbliższej perspektywie finansowej, lecz także na najbliższe kilkadziesiąt lat.

\subsubsection{Platności bezpośrednie a polityka zazieleniania}

Jednym z podstawowych zadań WPR po 2014 r. jest upowszechnienie działań o charakterze środowiskowym ${ }^{76}$. W tym celu do systemu płatności bezpośrednich

74 M.A. Król, Modele doradztwa rolniczego $w$ Polsce na tle rozwiązań przyjętych $w$ wybranych krajach członkowskich Unii Europejskiej, Warszawa 2013, s. 1-30.

75 J. Kania, System wiedzy i informacji rolniczej w rolnictwie polskim, [w:] Prace Naukowe Uniwersytetu Ekonomicznego we Wrocławiu, „Problemy Ekonomiczne i Społeczne. Agrobiznes”, 2014, nr 360, s. $55-62$.

76 J. Goździewicz-Biechońska, Nowe paradygmaty ochrony ziemi jako zasobu środowiska w prawie rolnym, „Przegląd Prawa Rolnego”, 2017, nr 1. 
dodano instrument prawny, który nazwano płatnością za zazielenienie ${ }^{77}$. Ogólnie rzecz ujmując rolnik chcący otrzymać płatności bezpośrednie będzie zobowiązany stosować praktyki korzystne dla klimatu. Zgodnie z rozporządzeniem 1307/2013 obejmują one takie praktyki, jak: dywersyfikacja upraw ${ }^{78}$; utrzymywanie istniejących trwałych użytków zielonych oraz utrzymywanie na użytkach rolnych obszaru proekologicznego. Przepisy w przywołanym rozporządzeniu wyraźnie określają prowadzenie każdej z tych praktyk i kryteria dostępu do systemu płatności bezpośrednich po ich spełnieniu. Ten mechanizm ma doprowadzić do ochrony środowiska oraz zróżnicowania upraw. Powstaje tylko pytanie: czy jego stosowanie zwiększy również konkurencyjność rolnictwa? Jeżeli będzie to powiązane z poprawą jakości produktów rolnych to z pewnością tak, ale jeżeli będzie to prowadziło tylko do przymusowego zazielenienia ${ }^{79}$ to efekt może być odwrotny.

Ponadto, państwo członkowskie może wprowadzić obowiązkowe praktyki, które będą równoważne do wyżej wymienionych. Dotyczy to przede wszystkim omówionych w kolejnym podrozdziale programów rolno-środowiskowo-klimatycznych lub mechanizmów certyfikacji środowiskowej. Rolnicy gospodarujący na obszarach cennych przyrodniczo mogą zostać zobowiązani do szczególnych działań, które będą zmierzać do zachowania walorów środowiskowych swoich gospodarstw ${ }^{80}$.

Niewątpliwie problemem tego instrumentu prawnego są liczne wymogi, które musi spełnić rolnik, aby uzyskać płatność zieloną. Wyzwaniem jest dostosowanie swoich gospodarstw do wprowadzonych obszarów proekologicznych, w tym również śródpolnych zadrzewień i przeznaczaniu obszarów uprawnych pod zielone pasy. W cytowanym rozporządzeniu 1307/2013 wskazano, że jeżeli powierzchnia kwalifikowanych

77 S. Kowalski, Dopłaty bezpośrednie w nowej perspektywie finansowej Unii Europejskiej na lata 2014-2020, „Zeszyty Naukowe PWSZ w Płocku. Nauki Ekonomiczne”, 2017, s. 153-164.

78 Obowiązek stosowania dywersyfikacji upraw dotyczy rolników posiadających co najmniej 10 ha gruntów ornych, z uwzględnieniem gruntów ornych nie deklarowanych do jednolitej płatności obszarowej. Praktyka dywersyfikacji upraw polega na utrzymaniu odpowiedniej liczby i powierzchni upraw na gruntach ornych $\mathrm{w}$ gospodarstwie rolnym $\mathrm{w}$ danym roku. W przypadku, gdy grunty orne zajmują: od 10 do 30 ha gruntów ornych - są wymagane minimum dwie różne uprawy na gruntach ornych, w tym uprawa główna nie powinna zajmować więcej niż 75\% gruntów ornych; powyżej 30 ha gruntów ornych - są wymagane minimum trzy uprawy na gruntach ornych; w tym uprawa główna nie może zajmować więcej niż 75\% gruntów ornych, a dwie uprawy główne łącznie nie mogą zajmować więcej niż 95\% gruntów ornych. Do celów dywersyfikacji za odrębną uprawę uznaje się: uprawę dowolnego gatunku $\mathrm{z}$ różnych rodzajów zdefiniowanych w klasyfikacji botanicznej upraw; uprawę dowolnego gatunku z rodzin kapustowatych (Brassicaceae), psiankowatych (Solanaceae) i dyniowatych (Cucurbitaceae); grunt ugorowany; trawę lub inne pastewne rośliny zielne, pszenicę orkisz Triticum spelta, formę jarą i ozimą tego samego rodzaju - https://www.arimr.gov.pl/pomoc-unijna/platnosci-bezposrednie/platnosci-bezposrednie-w-roku-2018/platnosci-bezposrednie-w-roku-2018/platnosc-za-zazielenienie/dywersyfikacjaupraw.html [data dostępu 30 marca 2019 r.].

79 J. Goździewicz-Biechońska, Zielona infrastruktura na obszarach wiejskich jako instrument polityki ochrony środowiska UE, „Studia Iuridica Lublinensia” 2017, t. 26, nr 1.

80 Por. D. Milanowska, Płatność za zazielenienie w nowym modelu dopłat bezpośrednich, „Studia Iuridica Agraria", Białystok 2015, t. 13, s. 7-18. 
gruntów rolnych w gospodarstwie z wyłączeniem trwałych użytków zielonych (TUZ) obejmuje ponad 15 ha, to rolnik powinien przeznaczyć 5\% ziemi na obszary proekologiczne (EFA) już od stycznia 2014 r. W przypadku, kiedy uzna, że wspomniane 5\% to za mało i nie dają one dobrych efektów, to będzie można obszary EFA podnieść w każdym gospodarstwie do 7\% począwszy od $2018 \mathrm{r} .{ }^{81}$. Oznacza to pozostawienie części nieruchomości rolnych nieużytecznym z punktu widzenia gospodarki rolnej, a jak najbardziej korzystnym z punktu widzenia środowiska naturalnego.

To swoiste nowe ,odłogowanie” gruntów rolnych dotyczy tym razem tylko gospodarstw uznawanych za średnie i duże. Przeznaczenie części nieruchomości na obszary proekologiczne może być niekorzystne dla dochodów rolniczych. Co prawda otrzymają oni w zamian odpowiednią płatność, która będzie stanowić uzupełnienie ich dochodów, ale może okazać się ona niewystarczająca. Prosty rachunek ekonomiczny wynikający z porównania wysokości przyznanej płatności a potencjalnym zyskiem możliwym do osiągnięcia gdyby jej nie było będzie przeważał w decyzjach rolników ${ }^{82}$.

Od tych decyzji zależy konkurencyjność rolnictwa i stan środowiska. Wybór odpowiedniego rozwiązania można ukierunkować podnosząc de lege ferenda wysokość płatności za zazielenianie (aktualnie jest to $308,18 \mathrm{zł} / \mathrm{ha}$ ). Wtedy być może atrakcyjność tego instrumentu prawnego wzrośnie. Podniesienie tej płatności pozytywnie wpłynie także na konkurencyjność rolnictwa. Środki te rolnicy będą mogli przeznaczyć na szeroko rozumiane inwestycje w swoje gospodarstwa. Powinno się to przyczynić do wzrostu ich wydajności i poprawienia dochodowości.

81 Zgodnie z art. 46 ust. 2 rozporządzenia 1307/2013 za obszary proekologiczne uznano:

- grunty ugorowane;

- tarasy;

- elementy krajobrazu, w tym elementy przylegające do gruntów ornych gospodarstwa;

- strefy buforowe, w tym strefy buforowe pod trwałymi użytkami zielonymi, pod warunkiem, że różnią się one od przylegającej kwalifikującej się powierzchni użytków rolnych;

- hektary rolno-leśne, które otrzymują lub otrzymywały wsparcie na mocy odrębnych przepisów;

- pasy kwalifikujących się hektarów wzdłuż obrzeży lasu;

- obszary z zagajnikami o krótkiej rotacji bez stosowania nawozów mineralnych lub środków ochrony roślin; obszary zalesione; obszary z międzyplonami lub pokrywą zieloną utworzone poprzez sadzenie i kiełkowanie nasion, do których stosuje się współczynniki ważenia;

- obszary objęte uprawami wiążącymi azot.

Nowelizacja przepisów w zakresie zazielenienia dotyczy listy obszarów proekologicznych (EFA). Przepisy UE dopuściły możliwość rozszerzenia od 2019 r. krajowego katalogu obszarów proekologicznych EFA o nowy element - grunty ugorowane z roślinami miododajnymi, bogatymi w pyłek i nektar. Ugorom tym został przypisany wyższy współczynnik ważenia $(1,5)$, odzwierciedlający znaczenie poszczególnych obszarów EFA dla różnorodności biologicznej, niż współczynnik dla pozostałych ugorów w ramach EFA $(1,0)$ - https://www.gov.pl/web/rolnictwo/platnosc-za-zazielenienie2 [data dostępu 30 marca 2019 r.].

82 W. Wrzaszcz, Skutki zazieleniania Wspólnej Polityki Rolnej na przykładzie gospodarstw prowadzacych rachunkowość rolna, „Roczniki Naukowe Stowarzyszenia Ekonomistów Rolnictwa i Agrobiznesu", 2017, t. 19, z. 4, s. 231-237. 
Unormowania europejskie przewidują także konsekwencje dla rolników, którzy nie będą przestrzegać powyżej określonych praktyk korzystnych dla klimatu. Jak wskazano w art. 77 ust. 6 rozporządzenia 1306/2013 w przypadku nieprzestrzegania praktyk zazielenienia na rolników będą nakładane kary administracyjne, polegające na zmniejszeniu kwoty otrzymanych w danym roku płatności bezpośrednich. Przez dwa pierwsze lata wdrażania zazielenienia kary te nie będą wykraczać poza kwotę otrzymanej płatności za zazielenienie i, w zależności od stopnia stwierdzonej niezgodności, będą obejmować część lub całość płatności za zazielenienie. Natomiast w kolejnych latach kary będą mogły nawet przewyższać otrzymaną kwotę zazielenienia (w $2017 \mathrm{r}$. o maksymalnie $20 \%$, a od 2018 r. o maksymalnie $25 \%$ ), co oznacza, że w razie stwierdzenia niezgodności, kara za nieprzestrzeganie praktyk zazielenienia spowoduje także częściowe zmniejszenie jednolitej płatności obszarowej.

Zastosowanie opisanych kar może sprawić, że rolnicy będą się obawiali korzystania z nowej formy pomocy, mając na względzie dość dotkliwe kary za nieprzestrzeganie praktyk korzystnych dla klimatu. Ponadto, trzeba będzie doprecyzować kryteria kontroli oraz sposoby jej przeprowadzania ${ }^{83}$.

Instrument ten może okazać się także przeszkodą w sytuacji, kiedy rolnicy będą chcieli zbyć część swoich nieruchomości, które akurat będą miały status trwałych użytków zielonych $\mathrm{w}$ trakcie roku, w którym będą pobierać dopłaty ${ }^{84}$. Powstaje pytanie: na jaki czas będzie liczony procentowy udział trwałych użytków zielonych w całym gospodarstwie? Należałoby uznać, iż na dzień składania wniosku, ale nie ma dość jasno określonych przepisów, które wprost zabraniałyby innej interpretacji.

Przedstawiony instrument zazieleniania jest nie tylko efektem nowej WPR. Jest też elementem szerszego spojrzenia na środowisko i klimat w Europie. Wprowadzone mechanizmy prawne są częścią całego systemu gospodarczego, który obejmuje przede wszystkim energetykę, emisję gazów i spalin, przemysł. Nie można odmówić racji pomysłodawcom tego instrumentu, że w dłuższej perspektywie jest on konieczny, w szczególności w sytuacji erozji gleb, zanieczyszczenia wód, czy problemów ze smogiem ${ }^{85}$.

Jego konstrukcja prawna - liczne wymogi, wyłączenia oraz system kar jest niezwykle skomplikowany. Powoduje nie tylko wątpliwości interpretacyjne, ale przede wszystkim zniechęca rolników do korzystania z niego. Postulując jego uproszczenie trzeba mieć w pamięci wizję WPR po 2020 r., gdzie mechanizmy tego typu będą miały jeszcze większe znaczenie. Ponad wszystko najważniejszym wydaje się argument

83 D. Łobos-Kotowska, Charakter prawny kontroli w przepisach ustawy z dnia 20 lutego $2015 \mathrm{r}$. o wspieraniu rozwoju obszarów wiejskich z udziałem środków EFRROW na lata 2014-2020, [w:] Integracja europejska jako determinanta polityki wiejskiej. Aspekty prawne, P. Litwiniuk (red.), Warszawa 2017.

84 A. Niewiadomski, The direct payments system in European and Polish agriculture with particular emphasis on the greening policy, „Studia Iuridica”, 2016, t. 66, s. 287-300.

85 E. Jachnik, Prawne aspekty ochrony zapachowej jakości powietrza, „Przegląd Prawa Rolnego” 2017 , nr 1 . 
poza prawny, który ma wpłynąć na jego skuteczność. Jest nim zwiększenie poziomu finansowania tego mechanizmu ${ }^{86}$.

Instrument ten wpisuje się również w koncepcję własności rolniczej Andrzeja Stelmachowskiego ${ }^{87}$. Zakłada on nie tylko uprawnienia właściciela nieruchomości rolnych, lecz także jego obowiązki względem społeczeństwa. Za te obowiązki rolnik ma prawo oczekiwać odpowiedniej rekompensaty. Stosowanie zazieleniania może być właśnie takim współczesnym obowiązkiem, wynikającym z własności rolniczej. Za jego spełnienie rolnik otrzymuje stosowną płatność - pomoc publiczną ${ }^{88}$. Należy jednakże podkreślić ponownie, że ta rekompensata powinna odzwierciedlać poniesione nakłady i utracone dochody.

\subsubsection{Działanie rolno-środowiskowo-klimatyczne}

Działanie rolno-środowiskowo-klimatyczne ${ }^{89}$ ma za zadanie promowanie praktyk przyczyniających się do zrównoważonego gospodarowania gruntami (w celu ochrony gleb, wód, klimatu), ochrony cennych siedlisk przyrodniczych i zagrożonych gatunków ptaków, różnorodności krajobrazu oraz ochrony zagrożonych zasobów genetycznych roślin uprawnych i zwierząt gospodarskich, a także ochrony różnorodności krajobrazu $^{90}$. Zgodnie z art. 28 ust. 1 rozporządzenia 1305/2013 państwa członkowskie udostępniają wsparcie w ramach tego działania na całym swoim terytorium zgodnie ze swoimi krajowymi, regionalnymi lub lokalnymi szczególnymi potrzebami i priorytetami. Działanie to ma na celu zachowanie oraz propagowanie niezbędnych zmian w praktykach rolnych, które stanowią pozytywny wkład w środowisko i klimat. Jego włączenie do programów rozwoju obszarów wiejskich jest obowiązkowe na poziomie krajowym lub regionalnym.

To kolejne podejście i wpisanie w wachlarz instrumentów WPR takich mechanizmów, które mają chronić klimat i środowisko. Rozszerzenie działań rolno-środowiskowych obowiązujących w PROW 2007-2013 na działania obejmujące klimat

${ }^{86}$ H. Runowski, Zróżnicowanie dochodów ludności rolniczej między krajami Unii Europejskiej i kierunki ich zmian, „Wieś i Rolnictwo”, 2018, nr 179, s. 65-84.

87 A. Stelmachowski, Treść i wykonywanie prawa własności, [w:] System Prawa Prywatnego, Prawo rzeczowe, T. Dybowski (red.), Warszawa 2007, t. 3, s. 187-314; P. Czechowski, M. Korzycka-Iwanow, S. Prutis, A. Stelmachowski, Polskie prawo rolne na tle ustawodawstwa Unii Europejskiej, Warszawa 1999, s. 21-27; M. Korzycka-Iwanow, S. Prutis, Własność rolnicza, [w:] Prawo rolne, P. Czechowski (red.), Warszawa 2015, s. 48, 49; M. Korzycka, Ochrona własności rolniczej, Warszawa 1979, s. 14; A. Stelmachowski, Współczesne zróżnicowanie własności, „Studia Iuridica Agraria”, Białystok 2002, t. 3, s. 17-38; T. Kurowska, Renesans własności rolniczej, „Przegląd Prawa Rolnego”, 2014, t. 15, nr 2, s. $23-44$.

88 T. Kurowska, Pomoc publiczna a ochrona środowiska w procesie produkcji rolnej, [w:] Integracja europejska jako determinanta polityki wiejskiej. Aspekty prawne, P. Litwiniuk (red.), Warszawa 2017.

89 E. Nawrotek, Działanie rolno-środowiskowo-klimatyczne jako instrument ochrony środowiska w rolnictwie, [w:] Prawne instrumenty ochrony środowiska, B. Jeżyńska, E. Kruk (red.), Lublin 2016.

90 PROW 2014-2020 pkt 8.2.10.2. 
są wyznacznikiem nowego podejścia do rolnictwa oraz polityki rolnej. Działania te nie mają bezpośredniego wpływu na konkurencyjność, ponieważ nie przekładają się wprost na dochody rolników ${ }^{91}$. Jednocześnie dbałość o środowisko i łączenie tego z rolnictwem ekologicznym jak najbardziej stanowi instrument prawny, który czyni z produktów rolnych wytwarzanych takimi metodami produkty konkurencyjne.

W ramach tego działania określono poddziałania „Płatności w ramach zobowiązań rolno-środowiskowo-klimatycznych”92 oraz „Wsparcie ochrony i zrównoważonego użytkowania oraz rozwoju zasobów genetycznych w rolnictwie"93. Pomoc jest udzielana na podstawie rozporządzenia Ministra Rolnictwa i Rozwoju Wsi z dnia 18 marca 2015 r. w sprawie szczegółowych warunków i trybu przyznawania pomocy finansowej w ramach działania „Działanie rolno-środowiskowo-klimatyczne” objętego Programem Rozwoju Obszarów Wiejskich 2014-202094.

W działaniu tym przewiduje się udzielanie dotacji, która ma rekompensować utracony dochód i dodatkowo poniesione koszty w związku ze stosowaniem korzystnych dla środowiska naturalnego praktyk rolniczych i powstrzymywaniem się od zabiegów agrotechnicznych nadmiernie wykorzystujących zasoby przyrody. Pomoc ta jest udzielana na pięć lat. Beneficjent programu powinien przygotować także plan działalności rolno-środowiskowej, a także posiadać dokumentację przyrodniczą, przygotowaną przez eksperta przyrodniczego ${ }^{95}$. $Z$ tego planu mogą wynikać dalsze wymogi

91 Z. Giersz, Instrument stabilizacji dochodów - nowy instrument zarzadzania ryzykiem w perspektywie Wspólnej Polityki Rolnej po 2013 r., Warszawa 2011, s. 6, 7; K. Zawalińska, E. Majewski, A. Wąs, Dlugookresowe zmiany w dochodach z polskiego rolnictwa na tle krajów UE, „Zeszyty Naukowe SERiA”, 2015, t. 17, z. 6, 2015, s. 2 i nast.

92 W ramach poddziałania (10.1) Płatności w ramach zobowiązań rolno-środowiskowo-klimatycznych pomoc będzie udzielana na następujące typy operacji (pakiety):

1. Rolnictwo zrównoważone.

2. Ochrona gleb i wód.

3. Zachowanie sadów tradycyjnych odmian drzew owocowych.

4. Cenne siedliska i zagrożone gatunki ptaków na obszarach Natura 2000.

5. Cenne siedliska poza obszarami Natura 2000 - PROW 2014-2020 pkt 8.2.10.2.

$93 \mathrm{~W}$ ramach poddziałania (10.2) „Wsparcie ochrony i zrównoważonego użytkowania oraz rozwoju zasobów genetycznych w rolnictwie" pomoc będzie udzielana na zachowanie lokalnych odmian roślin uprawnych oraz ochronę szczególnie cennych ras zwierząt gospodarskich, w przypadku których niska lub malejąca liczebność stwarza zagrożenie ich wyginięcia.

W ramach poddziałania (10.2), „Wsparcie ochrony i zrównoważonego użytkowania oraz rozwoju zasobów genetycznych w rolnictwie" pomoc będzie udzielana na następujące typy operacji (pakiety):

6. Zachowanie zagrożonych zasobów genetycznych roślin w rolnictwie.

7. Zachowanie zagrożonych zasobów genetycznych zwierząt w rolnictwie - PROW 2014-2020 pkt 8.2.10.2.

94 Rozporządzenie Ministra Rolnictwa i Rozwoju Wsi z dnia 18 marca 2015 r. w sprawie szczegółowych warunków i trybu przyznawania pomocy finansowej w ramach działania „Działanie rolno-środowiskowoklimatyczne” objętego Programem Rozwoju Obszarów Wiejskich 2014-2020 (Dz. U. poz. 415 z późn. zm.).

95 Przykładowo, tylko wymogi określone w PROW 2014-2020 dla rolnictwa zrównoważonego przedstawiają się następująco: Wymogi jakie muszą zostać spełnione w ramach Pakietu 1. Rolnictwo zrównoważone: 1. Obowiązek posiadania planu działalności rolnośrodowiskowej; 2. Obowiązek zacho- 
i zobowiązania rolnika. Mogą one ograniczać istotnie prawo własności nieruchomości poprzez wprowadzenie zakazów podejmowania pewnych czynności związanych $\mathrm{z}$ rolnictwem intensywnym.

W działaniu tym można nałożyć także na beneficjenta obowiązek prowadzenia uprawy lub wytwarzania materiału siewnego określonych odmian regionalnych lub amatorskich. Beneficjent może mieć także obowiązek realizacji programu ochrony zasobów genetycznych wybranych gatunków zwierząt gospodarskich ${ }^{96}$.

W zamian za takie zobowiązania rolnik otrzymuje wspomnianą dotację przyznawaną do powierzchni gruntów ornych położonych na terenie RP z zastosowaniem mechanizmu degresywnego, który oznacza, że im większe gospodarstwo tym procent dopłaty wynosi mniej (od 100 do 60\%). Taki sposób realizacji tego mechanizmu wpisuje się w preferowanie gospodarstw małych (w tym przypadku od 0,10 do 50 ha). Jest to związane z wspólną cechą większości analizowanych instrumentów ${ }^{97}$. Po raz kolejny należy podkreślić, że tego typu rozwiązania mogą spotkać się z zarzutem dyskryminacji i nierównego traktowania podmiotów wobec prawa.

Problemy istniejące na tych terenach dotyczą relacji podejmowanych zobowiązań środowiskowych a obowiązującymi aktami prawnymi dotyczącymi szeroko rozumianej ochrony przyrody. Problem ten analizowany już w polskiej nauce prawa rolnego $0^{98}$ dotyczy relacji tych zobowiązań, chociażby z planami parków, czy planami zadań ochronnych na obszarach Natura 2000. Słabością zobowiązań środowiskowych jest

wania wszystkich trwałych użytków zielonych i elementów krajobrazu nieużytkowanych rolniczo stanowiących ostoje dzikiej przyrody; 3 . Zastosowanie minimum czterech upraw* w plonie głównym w ciągu roku w gospodarstwie, w tym udział głównej rośliny, oraz łącznie zbóż w strukturze zasiewów nie może przekraczać $65 \%$ powierzchni gruntów ornych i jednocześnie: (i) w przypadku zastosowania czterech upraw - udział każdej uprawy nie może być mniejszy niż 10\% powierzchni gruntów ornych, (ii) w przypadku zastosowania więcej niż czterech upraw - udział każdej z trzech największych z tych upraw z osobna nie może być mniejszy niż $10 \%$ powierzchni gruntów ornych oraz udział pozostałych upraw łącznie nie może być mniejszy niż $10 \%$ powierzchni gruntów ornych $(*)$ uprawa - zdefiniowana w art. 44 ust. 4 rozporządzenia Parlamentu Europejskiego i Rady (UE) nr 1307/2013. 4. Dwukrotna chemiczna analiza gleby ( $\mathrm{pH}, \mathrm{P}, \mathrm{K}, \mathrm{Mg}$ i węgiel organiczny) - wykonana w pierwszym (lub poprzedzającym) i w piątym (lub poprzedzającym) roku realizacji pakietu; 5. Obowiązek corocznego opracowania i przestrzegania planu nawozowego, opartego na bilansie azotu oraz chemicznej analizie gleby, określającego dawki N, P, K, Mg i potrzeby wapnowania; 6 . Zastosowanie m.in. w celu uzyskania dodatniego bilansu materii organicznej na działce rolnej: $\mathrm{w}$ zmianowaniu minimum trzech grup upraw w ciągu 5 lat zobowiązania; najpóźniej w 4 roku okresu zobowiązania, w dwóch różnych latach: międzyplonu (wysiewanego w terminie do 1 października, przy jednoczesnym zakazie wznawiania zabiegów agrotechnicznych przed 15 lutego) oraz międzyplonu (j.w.) lub przyorania słomy lub przyorania obornika; 7. Koszenie lub wypas na trwałych użytkach zielonych; 8. Niestosowanie osadów ściekowych.

96 M. Wojcieszak, N. Szalaty, W. Wyduba, Wsparcie rolnictwa zrównoważonego w Polsce w ramach PROW 2014-2020 na przykładzie działania rolno-środowiskowo-klimatycznego, „Problemy Rolnictwa Światowego", 2018, t. 18, nr 33, s. 332-341.

97 B. Wieliczko, Zrównoważenie rolnictwa UE a WPR i strategia „Europa 2020, „Prace Naukowe Uniwersytetu Ekonomicznego we Wrocławiu”, 2016, nr 416, s. 164-171.

98 A. Niewiadomski, Publicznoprawny i prywatnoprawny konflikt interesów na przykładzie Europejskiej Sieci Ekologicznej Natura 2000, Warszawa 2017, s. 162-173. 
to, iż muszą one ustąpić tam, gdzie akty prawa powszechnie obowiązującego wynikającego z ustawy o ochronie przyrody będą inaczej określały obowiązki właściciela nieruchomości. De lege ferenda należałoby postulować ograniczenie możliwych kolizji i włączenie do planów rolno-środowiskowo-klimatycznych postanowień aktów prawnych obwiązujących na danym obszarze, a wynikających ze specjalnego statusu danego terenu.

\subsubsection{Rolnictwo ekologiczne}

Rolnictwo ekologiczne jest jednym z działań PROW 2014-2020. Zgodnie z art. 29 rozporządzenia 1305/2013 wsparcia w ramach tego działania udziela się na hektar użytków rolnych rolnikom lub grupom rolników, którzy dobrowolnie podejmują się konwersji na praktyki i metody rolnictwa ekologicznego lub utrzymania takich praktyk i metod określonych w rozporządzeniu (WE) nr 834/200799 i którzy są rolnikami aktywnymi zawodowo. Ten ostatni wymóg wiąże się z art. 9 rozporządzenia 1307/2013. Ponownie wiąże przyznanie pomocy z kryteriami umożliwiającymi uzyskanie płatności bezpośrednich ${ }^{100}$. Dowodzi to istnienia systemu powiązań i spełniania pewnych warunków wstępnych w celu uzyskania pomocy. Dlatego też określenie ram prawnych instrumentu prawnego, jakim jest rolnictwo ekologiczne, jest sumą kilku różnych regulacji ${ }^{101}$.

Pomoc jest przyznawana na podstawie rozporządzenia Ministra Rolnictwa i Rozwoju Wsi z dnia 13 marca 2015 r. w sprawie szczegółowych warunków i trybu przyznawania pomocy finansowej w ramach działania „Rolnictwo ekologiczne” objętego Programem Rozwoju Obszarów Wiejskich na lata 2014-2020102. Rolnictwo ekologiczne oznacza sposób gospodarowania o zrównoważonej produkcji roślinnej i zwierzęcej w obrębie gospodarstwa rolnego, oparty na środkach pochodzenia biologicznego i mineralnego nieprzetworzonych technologicznie. Zgodnie z PROW podstawową zasadą rolnictwa ekologicznego jest zaniechanie stosowania w procesie produkcji żywności środków chemii rolnej, weterynaryjnej i spożywczej. Zasada ta

99 Rozporządzenie Rady (WE) nr 834/2007 z dnia 28 czerwca 2007 r. w sprawie produkcji ekologicznej i znakowania produktów ekologicznych i uchylające rozporządzenie (EWG) nr 2092/91 (Dz. Urz. UE L Nr 189, s. 1 z późn. zm.).

100 R. Wojciechowski, Spoleczno-polityczne i ekonomiczne aspekty realizacji polityki ekologicznej, [w:] Administracja publiczna a ochrona przyrody. Zagadnienia ekonomiczne, społeczne oraz prawne, M. Górski, D. Niedziółka, R. Stec, D. Strus (red.), Warszawa 2012, s. 87-98.

101 S. Prutis, Regulacje prawne produkcji ekologicznej w rolnictwie polskim, „Studia Iuridica Agraria", Białystok 2013, t. 11, s. 39-60.

102 Rozporządzenie Ministra Rolnictwa i Rozwoju Wsi z dnia 13 marca 2015 r. w sprawie szczegółowych warunków i trybu przyznawania pomocy finansowej w ramach działania „Rolnictwo ekologiczne" objętego Programem Rozwoju Obszarów Wiejskich na lata 2014-2020 (Dz. U. z 2018 r. poz. 1784). 
dotyczy wszystkich rodzajów i etapów produkcji - zarówno uprawy roślin, chowu i hodowli zwierząt, jak i przetwórstwa ${ }^{103}$.

W ramach tego działania wyodrębniono poddziałania „Płatności w okresie konwersji na rolnictwo ekologiczne” 104 oraz „Płatności w celu utrzymania rolnictwa ekologicznego" 105 . Aby skorzystać z tej pomocy rolnicy muszą sporządzić plan działalności ekologicznej, sporządzony z udziałem specjalnego doradcy rolnośrodowiskowego. Ponadto, rolnicy muszą utrzymywać trwałe użytki zielone ${ }^{106}$ oraz tereny, na których znajdują się ostoje dzikiej przyrody.

Ważnym wymogiem oddziałującym istotnie na konkurencyjność jest obowiązek prowadzenia produkcji ekologicznej i odpowiedniego przeznaczenia plonu. Odnosi się to do przetwórstwa, sprzedaży, przekazania do innych gospodarstw czy spasania. Te podstawowe wymogi, precyzowane także przez dodatkowe, mają sprawić upowszechnienie upraw ekologicznych, a co za tym idzie podnieść poziom bezpieczeństwa żywności ${ }^{107}$.

W tym instrumencie prawnym pomoc jest udzielana w formie dotacji dla rolników aktywnych zawodowo. To kolejne połączenie wymogów z regulacji płatności bezpośrednich oraz polityki rozwoju obszarów wiejskich. Powoduje to konieczność stosowania wykładni systemowej w celu pełnego określenia treści danego instrumentu prawnego. Zgodnie z PROW do płatności w ramach pakietów są uprawnione gospodarstwa posiadające ważny certyfikat wydany przez upoważnioną jednostkę certyfikującą, zgodnie z przepisami o rolnictwie ekologicznym ${ }^{108}$. Płatności w ramach pakietów są przyznawane corocznie przez okres maksymalnie do 5 lat beneficjentom, którzy dobrowolnie przyjmują na siebie zobowiązanie w zakresie tych pakietów. Płatność w całości lub w części rekompensuje utracony dochód i dodatkowo poniesione koszty ${ }^{109}$.

103 PROW 2014-2020 pkt 8.2.11.2.

104 Płatności w okresie konwersji na rolnictwo ekologiczne - pomoc będzie udzielana na następujące typy operacji (pakiety): 1. Uprawy rolnicze w okresie konwersji. 2. Uprawy warzywne w okresie konwersji. 3. Uprawy zielarskie w okresie konwersji. 4. Uprawy sadownicze w okresie konwersji. 5. Uprawy paszowe na gruntach ornych w okresie konwersji. 6. Trwałe użytki zielone w okresie konwersji.

$105 \mathrm{~W}$ ramach poddziałania (11.2) „Płatności w celu utrzymania rolnictwa ekologicznego” pomoc udzielana będzie na następujące typy operacji (pakiety): 7. Uprawy rolnicze po okresie konwersji. 8. Uprawy warzywne po okresie konwersji. 9. Uprawy zielarskie po okresie konwersji. 10. Uprawy sadownicze po okresie konwersji. 11. Uprawy paszowe na gruntach ornych po okresie konwersji. 12. Trwałe użytki zielone po okresie konwersji.

106 P. Burczyk, D. Gamrat, M. Gałczyńska, E. Saran, Rola trwałych użytków zielonych w zapewnieniu stanu równowagi ekologicznej środowiska przyrodniczego, „Woda, Środowisko, Obszary Wiejskie”, 2018 , t. 18 , z. 3, s. 21-37.

107 J. Kaczorowska, K. Rejman, E. Halicka, Wptyw certyfikatu rolnictwa ekologicznego na gotowość konsumentów do zapłaty wyższej ceny za owoce, „Handel Wewnętrzny”, 2018, t. 374, nr 3, s. 197-207.

108 Por. ustawa z dnia 25 czerwca 2009 r. o rolnictwie ekologicznym (Dz. U. z 2017 r. poz. 1054 z późn. zm.) oraz cytowane rozporządzenie Rady (WE) nr 834/2007.

109 PROW 2014-2020 8.2.11.3.1.2. 
Tego typu podejście oznacza, że rolnictwo ekologiczne co do zasady obecnie jest mniej konkurencyjne ${ }^{110}$. Aby pozostać na rynku beneficjent otrzymuje dotacje, które mają mu zrekompensować zarówno ponoszone zwiększone koszty, jak i utracony dochód. Jest to mechanizm interwencji publicznej, który próbując zmienić sposób gospodarowania dotuje daną branżę 111 . Powstaje pytanie: co się wydarzy kiedy takich dotacji braknie i rolnicy nie będą już tak skorzy do produkcji ekologicznej, która z natury rzeczy jest mniejsza i przynosi nie tak wysoki dochód jakby osiągnęli, prowadząc rolnictwo intensywne.

Problemem jest również brak regulacji związanych z sąsiedztwem upraw ekologicznych. Wystarczy, że na polu obok takiej uprawy sąsiad stosuje nawozy sztuczne, które przedostają się do wód gruntowych, a potem do uprawy ekologicznej i rolnik nie tylko może utracić dotację, a w efekcie zbankrutować, ale także zostanie mu odebrany certyfikat, który jest warunkiem koniecznym do ubiegania się o tę pomoc. De lege ferenda należy postulować pilne uregulowanie statusu upraw ekologicznych oraz nieruchomości sąsiedzkich. Bez tego typu unormowań instrument ten nie będzie w pełni spełniał swojego zadania, a na rynek mogą trafiać produkty, które nie będą ekologiczne ${ }^{112}$.

Rolnictwo ekologiczne jest potrzebnym instrumentem prawnym WPR. Nie oddziałuje ono bezpośrednio w dużej skali na konkurencyjność rolnictwa ${ }^{113}$. Stanowi jednakże wyzwanie przyszłości w zakresie dbania o zdrowie konsumentów ${ }^{114}$ i bezpieczeństwo żywności ${ }^{115}$. Pozwala także zmieniać nawyki żywieniowe ${ }^{116}$ społeczeństwa. Godzą się oni ponieść nieco wyższe koszty nabycia danego produktu, w zamian za gwarancję jego jakości i wartości odżywczych.

110 M. Trajer, K. Krzyżanowska, Rolnictwo ekologiczne w Polsce i perspektywy jego rozwoju w kontekście PROW 2014-2020, „Turystyka i Rozwój Regionalny”, 2017, nr 8, s. 115-126.

111 Stawka płatności: Pakiet 7. Uprawy rolnicze po okresie konwersji - 932 zł/ha, Pakiet 8. Uprawy warzywne po okresie konwersji - $1310 \mathrm{z}$ /ha, Pakiet 9. Uprawy zielarskie po okresie konwersji - $1325 \mathrm{zz} /$ ha, Pakiet 10. Uprawy sadownicze po okresie konwersji - $1501 \mathrm{zl} /$ ha (podstawowe uprawy sadownicze) i 660 zł/ha (ekstensywne uprawy sadownicze), Pakiet 11. Uprawy paszowe na gruntach ornych po okresie konwersji - 658 zł/ha, Pakiet 12. Trwałe użytki zielone po okresie konwersji - 535 zł/ha.

112 H. Runowski, Rolnictwo ekologiczne - rozwój czy regres, „Roczniki Nauk Rolniczych”, Seria G, 2009, nr 96, s. 182-193.

113 J. Kondratowicz-Pozorska, Konkurencyjność przedsiębiorstwa w świetle zrównoważonego rozwoju (na przykładzie ekologicznych gospodarstw rolnych), „Prace Naukowe Uniwersytetu Ekonomicznego we Wrocławiu", 2016, nr 417, s. 55-63.

114 A. Kowalska, Rolnictwo ekologiczne jako czynnik rozwoju zrównoważonej konsumpcji, „Journal of Agribusiness and Rural Development”, 2015, t. 37, nr 3, s. 467-476; M. Pietruk, Nowe tendencje wsparcia rolnictwa ekologicznego, „Studia Iuridica Agraria”, Białystok 2017, t. 15, s. 183-197.

115 M. Głodowska, A. Gałązka, Wpływ rolnictwa ekologicznego na środowisko w koncepcji rozwoju zrównoważonego, „Wieś i Rolnictwo”, 2017, nr 175, s. 147-165.

116 M. Korzycka-Iwanow, P. Wojciechowski, Żywność ekologiczna w prawie USA i Unii Europejskiej, „Studia Iuridica Agraria”, Białystok 2015, t. 13, s. 19-38. 


\subsection{Platności bezpośrednie jako instrument wpływający na konkurencyjność rolnictwa}

Podstawowym i powszechnym mechanizmem wsparcia rolników jest system płatności bezpośrednich. W Polsce objętych jest nim 1,4 mln osób i około $14 \mathrm{mln}$ ha użytków rolnych ${ }^{117}$. Jego ewolucja opisana w rozdziale drugim niniejszej pracy była wyznaczana przez kolejne reformy WPR. Aktualna debata nad kształtem polityki rolnej po 2020 r. również skłania do zastanawiania się nad przyszłością tego instrumentu prawnego. $Z$ zaprezentowanych projektów aktów prawnych wynika, że mechanizm ten zostanie utrzymany jako podstawowe wsparcie dla rolników w Europie. Nadal będą preferowane gospodarstwa małe oraz premiowana będzie polityka zazieleniania.

Aktualnie zasady przyznawania płatności bezpośrednich są regulowane rozporządzeniem 1307/2013 oraz ustawą o płatnościach w ramach systemów wsparcia bezpośredniego ${ }^{118}$. Do płatności bezpośrednich zaliczono jednolitą płatność obszarową (JPO); płatność z tytułu praktyk rolniczych korzystnych dla klimatu i środowiska (tzw. płatność za zazielenienie); płatność dla młodych rolników; płatność dodatkową (redystrybucyjną); płatności związane z produkcją; płatności w ramach przejściowego wsparcia krajowego oraz system dla małych gospodarstw. Podstawowym mechanizmem jest jednolita płatność obszarowa. Pozostałe są płatnościami fakultatywnymi.

Jako podstawowy mechanizm jest płatnością do hektara. To rolnik decyduje na co przeznaczy uzyskane środki. Mogą to być inwestycje w gospodarstwo, ale równie dobrze na zakup dóbr konsumpcyjnych. Tylko sprawozdawczość FADN pozwala ocenić, na ile środki z JPO są inwestowane w rolnictwo. Poza tym sprawozdania te opierają się na wiedzy rolników, którzy mogą nie być skorzy do przekazywania rzetelnych danych o prowadzonej przez siebie działalności rolniczej. Mechanizm ten ze względu na wielkość przeznaczanych środków wydatkowany na inwestycje może znacząco wpływać na wzrost konkurencyjności.

Niewątpliwie jednym z czynników utrudniających dostęp do tego instrumentu jest szereg informacji wymaganych od rolnika ${ }^{119}$. Może on sobie $\mathrm{z}$ nimi nie poradzić, a wtedy nie tylko nie są mu udzielane płatności, ale nie może ubiegać się o inne wybrane płatności bezpośrednie. Problemem jest także konieczność spełnienia licznych wymogów. Niektórzy rolnicy w Polsce nie są w stanie spełnić nawet zasad wzajemnej zgodności. Prowadzi to do powstawania dwóch typów gospodarstw. Tych, które korzystają ze wsparcia i prawdopodobnie poradzą sobie na wolnym rynku i tych, które nie będą w stanie przynieść takiego dochodu rolnikowi, aby wystarczyło na jego

117 Por. http://www.minrol.gov.pl/Wsparcie-rolnictwa-i-rybolowstwa/Platnosci-bezposrednie [data dostępu 30 marca 2019 r.].

118 J. Bieluk, D. Łobos-Kotowska, Ptatności bezpośrednie, [w:] Prawo rolne, P. Czechowski (red.), Warszawa 2015, s. 410-423.

119 W. Czubak, A. Sadowski, Dostępność informacji oraz czynniki utrudniające ubieganie się o dopłaty bezpośrednie, „Wieś i Rolnictwo”, 2010, $\mathrm{nr} 3$. 
utrzymanie. Żądanie jednak utrzymywania gospodarstw w dobrej kulturze rolnej nie wydaje się zbyt wygórowanym wymaganiem.

Do innych kryteriów dostępu w tym instrumencie prawnym należy spełnianie wymogu „kwalifikującego się hektara”. Za takie są uznawane wszelkie użytki rolne gospodarstwa rolnego, w tym obszary, które w dniu 30 czerwca 2003 r. nie były utrzymywane w dobrej kulturze rolnej. Ponadto, kwalifikującym się hektarem jest każdy obszar, który zapewnił rolnikowi prawo do jednolitej płatności obszarowej w $2008 \mathrm{r}$. i który nie spełnia warunków kwalifikowalności ze względu na: objęcie tego obszaru ochroną na mocy dyrektyw: w sprawie ochrony siedlisk przyrodniczych oraz dzikiej fauny i flory, ramowej dyrektywy wodnej, dyrektywy w sprawie ochrony dzikiego ptactwa oraz zalesienie tego obszaru w ramach PROW 2007-2013 lub PROW 2014-2020 (zalesienie od jesieni 2008 r. (z wyjątkiem zalesień na gruntach innych niż rolne). Po spełnieniu tego warunku rolnik musi spełnić jeszcze kolejne ${ }^{120}$.

Jednolita płatność obszarowa przysługuje do: obszarów kwalifikowanych pozostających w posiadaniu rolnika w dniu 31 maja roku, w którym rolnik składa wniosek, a także kwalifikowanych obszarów, na których jest prowadzona działalność rolnicza przez cały rok kalendarzowy, z wyjątkiem przypadków działania siły wyższej lub okoliczności nadzwyczajnych. Przysługuje ponadto do użytków rolnych (łącznie z gruntami, które nie są już wykorzystywane do celów produkcyjnych), utrzymywanych w dobrej kulturze rolnej zgodnej z ochroną środowiska oraz obszarów, które zostały zatwierdzone, tj. będą stanowić obszar, w odniesieniu do którego spełniono wszystkie kryteria kwalifikowalności lub inne obowiązki związane z warunkami przyznania pomocy ${ }^{121}$.

Jednolita płatność obszarowa może zostać przyznana w kwocie nie większej niż równowartość 150 tys. euro (tzw. mechanizm redukcji płatności - degresywność) ${ }^{122}$. Oznacza to ponowne ograniczenie płatności dla rolników mających duże gospodarstwa rolne. Zgodnie $\mathrm{z}$ art. 7 ust. 1 ustawy o płatnościach w ramach wsparcia bezpośredniego płatności bezpośrednie są przyznawane rolnikowi, jeżeli został mu nadany numer identyfikacyjny w trybie przepisów o krajowym systemie ewidencji producentów, ewidencji gospodarstw rolnych oraz ewidencji wniosków o przyznanie płatności. Ponadto, łączna powierzchnia gruntów objętych obszarem zatwierdzonym będących w posiadaniu tego rolnika jest nie mniejsza niż 1 ha. Oznacza to konieczność wpisania

120 W. Poczta, A. Sadowski, Wplyw proponowanej reformy systemu dopłat bezpośrednich po 2013 roku na sytuację polskiego rolnictwa, „Wieś i Rolnictwo”, 2011, nr 4.

121 Przysługuje także do obszarów wykorzystywanych do produkcji konopi, jeżeli stosowane odmiany będą zawierać maksymalny poziom $0,2 \%$ tetrahydrokannabinolu (THC) w suchej masie rośliny, przy czym kwalifikowalność obszarów wykorzystywanych do produkcji konopi, będzie zależeć od wykorzystywania nasion odmian, wymienionych we wspólnym katalogu odmian gatunków roślin rolniczych w dniu 15 marca w roku, na który płatność została przyznana i opublikowanych w „Dzienniku Urzędowym Wspólnot Europejskich”.

122 D. Milanowska, Płatność za zazielenienie w nowym modelu dopłat bezpośrednich, „Studia Iuridica Agraria”, Białystok 2015, t. 13, s. 7-18. 
się rolnika do ewidencji producentów rolnych. Daje to gwarancję spełniania podstawowych zasad prowadzenia działalności rolniczej. Oczywiście w tych zasadach uwzględnia się podstawowe zasady związane z ochroną środowiska ${ }^{123}$.

Trudnością oceny efektywności tego instrumentu prawnego poza ogólnym wzrostem dochodowości gospodarstw rolnych i poprawy wskaźników ekonomicznych jest brak jasnych kryteriów wyodrębniających udział środków z JPO we wszystkich pieniądzach, które oddziałują na rolnictwo. $Z$ uwagi, iż jest to instrument powszechny, nie celowany w konkretne inwestycje trudno jest ocenić na ile poprawia on konkretne parametry konkurencyjności, a na ile przyczynia się tylko do poprawy sytuacji dochodowej rolnika. Oznaczenie tych środków i wprowadzenie wymogu inwestowania ich w rolnictwo wydaje się zabiegiem koniecznym, jeżeli płatności bezpośrednie mają zwiększać konkurencyjność rolnictwa.

\subsection{Instrumenty funkcjonujące na jednolitym rynku rolnym}

Jednym z ważnych celów WPR jest organizacja jednolitego rynku rolnego. Pozwala on nie tylko na swobodny przepływ towarów, ale przede wszystkim dba o bezpieczeństwo konsumentów. W tym celu sformułowano szereg wymogów jakościowych i ilościowych w odniesieniu do produkcji rolnej. Jednocześnie na tym rynku przewidziano szereg instrumentów prawnych, które mają po pierwsze go organizować, a po drugie pomagać finansowo rolnikom.

Regulacje dotyczące rynków rolnych przeszły znamienną ewolucję. Od typowo branżowych i sektorowych, po ujęcie horyzontalne. Z nowym podejściem do rynku rolnego jako całości i wypracowaniu na nim wspólnych mechanizmów można się spotkać od czasu wydania, nieobowiązującego już obecnie rozporządzenia Rady (WE) nr 1234/2007 z dnia 22 października 2007 r. ustanawiające wspólną organizację rynków rolnych oraz przepisy szczegółowe dotyczące niektórych produktów rolnych (rozporządzenie o jednolitej wspólnej organizacji rynku) ${ }^{124}$. Od tego czasu wydano także omawiane w rozdziale trzecim niniejszej pracy rozporządzenie 1308/2013. Utrzymuje ono podejście horyzontalne do rynku rolnego. Oznacza to istnienie jednolitych mechanizmów prawnych, którymi można się posługiwać, m.in. w celu podniesienia poziomu konkurencyjności rolnictwa.

Ponadto, w rozporządzeniu 1308/2013 wskazano na szereg instrumentów prawnych, które są stosowane w handlu z państwami trzecimi. One także realizując cele WPR stają się narzędziem wpływającym na konkurencyjność. Należy podkreślić, że

123 M.A. Król, Nowe rozwiązania prawne $w$ zakresie płatności $w$ ramach systemów wsparcia bezpośredniego, „Studia Iuridica Agraria”, Białystok 2015, t. 13, s. 77-100

124 Rozporządzenie Rady (WE) nr 1234/2007 z dnia 22 października 2007 r. ustanawiające wspólną organizację rynków rolnych oraz przepisy szczegółowe dotyczące niektórych produktów rolnych (rozporządzenie o jednolitej wspólnej organizacji rynku) (Dz. Urz. UE L Nr 299, s. 1 z późn. zm.). 
instrumenty te są określane i ewoluują wraz z całą polityką rolną. Niektóre z nich zanikają, inne stają się kluczowym wyzwaniem.

\subsubsection{Instrumenty funkcjonujące na jednolitym rynku wewnątrz Unii Europejskiej}

W rozporządzeniu 1308/2013 podkreślono w motywie 1, że „reforma powinna także, w miarę możliwości, zharmonizować i uprościć przepisy, w szczególności te, które obejmują więcej niż jeden sektor rolny, w tym poprzez zapewnienie Komisji możliwości przyjmowania innych niż istotne elementów środków w drodze aktów delegowanych". Uproszczenie mechanizmów prawnych jest powtarzane praktycznie przy każdym instrumencie prawnym. Przy organizacji rynku rolnego musi on jednak wybrzmieć dość głośnio. Rozporządzenie jest na tyle skomplikowane, że wydano już kilka jego nowelizacji, a w kolejnej perspektywie z pewnością trzeba będzie go napisać od początku. Postulat uproszczenia omawianych przepisów dotyczy przede wszystkim organizacji rynku rolnego wewnątrz Unii.

\subsubsection{Interwencja publiczna na rynku rolnym}

Najstarszym, a zarówno najprostszym instrumentem prawnym na rynku rolnym jest interwencja publiczna ${ }^{125}$. Mechanizm ten pozwala organom władzy publicznej za publiczne środki zaingerować w wolny rynek i skupić odpowiednie produkty. Co do zasady taka ingerencja w ustroju liberalnym jest niedopuszczalna. Dlatego też przez kolejne lata wprowadzano kolejne modyfikacje tego instrumentu, aby poprzez dodawanie różnych wymogów ograniczyć jego nadużywanie.

Zgodnie z art. 11 rozporządzenia 1308/2013 interwencję publiczną stosuje się w odniesieniu do produktów takich, jak: pszenica zwyczajna, pszenica durum, jęczmień i kukurydza; ryż niełuskany; świeża lub schłodzona wołowina i cielęcina objęte kodami CN 02011000 oraz od 02012020 do 020120 50; masło wyprodukowane bezpośrednio i wyłącznie z pasteryzowanej śmietanki, uzyskanej bezpośrednio i wyłącznie z mleka krowiego w zatwierdzonym przedsiębiorstwie w Unii, o minimalnej zawartości tłuszczu mlecznego w masie wynoszącej 82\% i maksymalnej zawartości wody w masie wynoszącej $16 \%$. W końcu interwencją jest objęte także odtłuszczone mleko w proszku najwyższej jakości, wytworzone z mleka krowiego metodą rozpyłową w zatwierdzonym przedsiębiorstwie w Unii, o minimalnej zawartości białka, wynoszącej 34,0\% w odtłuszczonej masie suchej ${ }^{126}$.

125 A. Stelmachowski, Agencje interwencyjne: Agencja Rynku Rolnego oraz Agencja Restrukturyzacji i Modernizacji Rolnictwa, [w:] Prawo rolne, A. Stelmachowski (red.), Warszawa 2009, s. 430-443.

126 A. Jarosz-Angowska, Instrumenty regulacji rynków rolnych $w$ uwarunkowaniach wspólnej polityki rolnej UE, „Studia Ekonomiczne”, 2017, nr 312, s. 40-50. 
To pierwsze ograniczenie przedmiotowe instrumentu interwencji. Uprawniony podmiot nie może skupywać wszystkich produktów z rynku. Może przeprowadzić interwencję publiczną tylko do enumeratywnie wyliczonych produktów z najbardziej wrażliwych ekonomicznie sektorów. Oznacza to istotne ograniczenie tego mechanizmu i jego rzeczywistego wpływu na konkurencyjność rolnictwa. Aktualnie wydaje się on być wentylem bezpieczeństwa dla sytuacji nadzwyczajnych.

Twierdzenie powyższe będzie tym bardziej zasadne, jeżeli przyjrzymy się konstrukcji tego instrumentu poprzez pryzmat innych wymogów. Po pierwsze, można przeprowadzać interwencję publiczną w ściśle określonych okresach ${ }^{127}$. Już sam ten mechanizm nie pozwala na dowolność stosowania tego mechanizmu. Po drugie, jest ograniczony krąg podmiotów ściśle określony w rozporządzeniu. Kluczową rolę w tym zakresie odgrywa Komisja Europejska, która poprzez akty wykonawcze może otworzyć interwencję, jeśli zostaną spełnione wszystkie przesłanki rynkowe (w odniesieniu do każdego $\mathrm{z}$ wymienionych produktów są one inaczej precyzowane). Zakup interwencyjny odbywa się po określonej cenie interwencyjnej.

$\mathrm{Z}$ ceną interwencyjną są skorelowane także inne rodzaje cen takie, jak preferencyjna, maksymalna czy minimalna ${ }^{128}$. Określanie pułapu cenowego jest jednym z najstarszych mechanizmów interwencji publicznej. Aktualnie można zaobserwować znaczne ograniczenie rodzajów cen na rynku, a także ich coraz mniejsze znaczenie ekonomiczne ${ }^{129}$.

Na konkurencyjność oddziałuje wprowadzenie nabytego towaru ponownie na rynek. W tym zakresie art. 16 ust. 1 rozporządzenia 1308/2013 wskazuje, że zbywanie produktów zakupionych w ramach interwencji publicznej odbywa się w taki sposób, aby: zapobiec jakimkolwiek zakłóceniom na rynku; zapewnić równy dostęp do towarów i równe traktowanie nabywców, oraz zapewnić zgodność z zobowiązaniami wynikającymi z umów międzynarodowych zawartych zgodnie z TFUE. Oznacza to, że zbycie towarów powinno się odbywać w taki sposób, aby nie zakłócić konkurencji na rynku.

Instrument interwencji publicznej powinien pozostać nadal w wachlarzu mechanizmów, za pomocą których są realizowane cele WPR. Jego aktualny stan regulacji, poza kwestią uznaniowości w jego zarządzeniu, a także dość długim czasie, który jest potrzebny do wydania rozporządzenia wykonawczego, może okazać się odpowiedni również w przyszłej perspektywie finansowej.

$127 \mathrm{~W}$ odniesieniu do pszenicy zwyczajnej, pszenicy durum, jęczmienia i kukurydzy - od dnia 1 listopada do dnia 31 maja; w odniesieniu do ryżu niełuskanego - od dnia 1 kwietnia do dnia 31 lipca; w odniesieniu do wołowiny i cielęciny - przez cały rok; 45 w odniesieniu do masła i odtłuszczonego mleka w proszku - od dnia 1 marca do dnia 30 września.

128 A. Zawojska, B. Horbowiec, Ryzyko cenowe na rynku produktów rolno-żywnościowych: źródta, skutki i sposoby zarządzania, „Zeszyty Naukowe SGGW. Ekonomika i Organizacja Gospodarki Żywnościowej”, 2016, nr 115, s. 39-58.

129 B. Czyżewski, A. Majchrzak, Związek dochodów, cen i produktywności w rolnictwie w Polsce - ujęcie makroekonomiczne, „Roczniki Naukowe Stowarzyszenia Ekonomistów Rolnictwa i Agrobiznesu", 2015, nr 17. 


\subsubsection{Dopłaty do prywatnego przechowania}

Przez długi okres ważnym instrumentem prawnym oddziałującym na rynek rolny były dopłaty do prywatnego przechowania. Obowiązują one także obecnie, chociaż ich zasięg oddziaływania jest dość ograniczony. Zgodnie z art. 17 rozporządzenia 1308/2013 dopłaty do prywatnego przechowywania mogą być przyznawane w odniesieniu do: cukru białego; oliwy z oliwek; włókna lnianego; świeżego lub schłodzonego mięsa $\mathrm{z}$ bydła w wieku ośmiu miesięcy lub więcej; masła wyprodukowanego ze śmietanki uzyskanej bezpośrednio i wyłącznie z mleka krowiego; sera; odtluszczonego mleka w proszku wyprodukowanego z mleka krowiego; wieprzowiny ${ }^{130}$; mięsa baraniego i koziego ${ }^{131}$.

Powyższy katalog enumeratywnie wyliczonych produktów preferuje tylko te branże. Samo to podejście już wpływa na konkurencyjność, gdzie inne produkty nie mogą korzystać z tego mechanizmu. Instrument ten dotyczy produktów, które wymagają specjalistycznych pomieszczeń do przechowywania.

Dopłaty do prywatnego przechowania może wprowadzić Komisja Europejska na mocy rozporządzenia wykonawczego. Mechanizm ten ma charakter interwencyjny i jest używany w sytuacjach nadzwyczajnych na rynku. Jednocześnie procedura wydawania aktów prawnych przez Komisję Europejską jest zbyt długotrwała, aby móc w pełni skutecznie zadziałać w odpowiednim czasie.

\subsubsection{Programy pomocy}

Programy pomocy obejmują kilka rodzajów wsparcia. Są instrumentem dość nowym, który w każdym okresie programowania przechodzi różne zmiany zależne od bieżących celów i pomysłów. Jednocześnie pogramy te są na tyle duże, że w dość znaczny sposób wpływają na funkcjonowanie danego sektora rynku.

Jednym z programów jest pomoc dotycząca dostarczania owoców i warzyw ${ }^{132}$ oraz mleka i przetworów mlecznych ${ }^{133} \mathrm{w}$ placówkach oświatowych. Zgodnie $\mathrm{z}$ art. 22 roz-

130 M. Trajer, Dopłaty do prywatnego przechowywania wieprzowiny jako forma interwencji rynkowej, ,Roczniki Naukowe Stowarzyszenia Ekonomistów Rolnictwa i Agrobiznesu”, 2013, nr 4; M. Hejbudzki, Normatywne struktury funkcjonowania podmiotów gospodarczych w mechanizmie dopłat do prywatnego przechowywania na rynku wieprzowiny, „Studia Iuridica Lublinensia”, 2017, nr 26, s. 399-413.

131 J. Ołowski, M. Trajer, Unijny system regulacji wsparcia rynków rolnych, ze szczególnym uwzględnieniem instrumentów wdrażanych przez Agencję Rynku Rolnego, „Studia BAS”, 2016, $\mathrm{nr} 48$.

132 K. Pietrkiewicz, M. Zajdel, M. Michalcewicz-Kaniowska, Wdrażanie programu „Owoce $i$ warzywa w szkole” jako element profilaktyki zdrowotnej w Polsce, „Marketing i Rynek”, 2015, nr 10, s. 244-254; M. Trajer, K. Krzyżanowska, Program „Owoce w szkole” - realizacja i skuteczność w ksztaltowaniu nawyków żywieniowych u dzieci, „Roczniki Ekonomii Rolnictwa i Rozwoju Obszarów Wiejskich”, 2012, nr 99, s. 114-123.

133 A Suchoń, Funkcjonowanie rynku mleka po likwidacji kwotowania - wybrane aspekty prawne, „Studia Iuridica Agraria”, Białystok 2016, t. 14, s. 297-313. 
porządzenia 1308/2013, programem pomocy, który ma poprawić dystrybucję produktów rolnych i polepszyć nawyki żywieniowe dzieci, objęte są dzieci, które regularnie uczęszczają do żłobków, przedszkoli lub szkół podstawowych lub średnich zarządzanych lub zatwierdzonych przez właściwe organy państw członkowskich. Polega on na finansowaniu dostarczania i dystrybucji kwalifikujących się produktów do powyżej określonych podmiotów. Finansowaniu podlegają także towarzyszące środki edukacyjne oraz pokrycie niektórych powiązanych kosztów sprzętu, reklamy, monitorowania.

Ogólnie rzecz ujmując instrument ten ma dwojaki charakter. Z jednej strony jest instrumentem społecznym, mającym zachęcić dzieci do spożywania zdrowych produktów rolnych, a przez to zapobiec wielu chorobom. Może także wpływać na dożywianie dzieci, które cierpią głód. $Z$ drugiej strony jest instrumentem interwencji, gdyż za publiczne środki jest finansowany zakup na dużą skalę określonych produktów rolnych. Problemy również są ze stosowaniem tego instrumentu. Konkretnie zbyt małymi stawkami dziennymi na dostarczane produkty i szczegółowymi wymogami ich dystrybucji ${ }^{134}$. Program ten w założeniach dobrze pomyślany, nie może uzyskać odpowiedniego poziomu wykorzystania, z uwagi na braki potencjalnych dostawców. Dotyczy to przede wszystkim produktów rolnych na rynku mleka ${ }^{135}$, które jest produktem o krótkim terminie przydatności. Zwiększenie poziomu finansowania tego instrumentu z pewnością poprawi jego dostępność i zachęci do korzystania z niego kolejne placówki oświatowe. Istnieją również przewidziane w rozporządzeniu 1308/2013 inne programy. Przykładowo, można tylko wymienić programy wsparcia dla sektora oliwy z oliwek i oliwek stołowych; pomoc dla sektora owoców i warzyw; programy wsparcia w sektorze wina; pomoc w sektorze pszczelarskim ${ }^{136}$; pomoc w sektorze chmielu. Mają one znaczenie także w innych państwach członkowskich. Działają jako instrument interwencji na rynku.

\subsubsection{Instrumenty wprowadzenia do obrotu produktów rolnych}

Na jednolitym rynku rolnym stworzono szereg instrumentów prawnych umożliwiających wprowadzenie produktów do obrotu. Pełnią one różne funkcje. $Z$ jednej strony pozwalają wprowadzić jednolite zasady na całym rynku europejskim, co stwarza taką samą pozycję konkurencyjną. $Z$ drugiej zaś strony pozwalają zachować pewne

134 Przykładowo produkty te nie mogą zawierać dodatku cukru; dodatku soli; dodatku thuszczu; dodatku substancji słodzących; dodatku sztucznych wzmacniaczy smaku o oznaczeniach od E 620 do E 650 .

135 A. Suchoń, Z prawno-ekonomicznej problematyki organizacji rynku mleka, „Przegląd Prawa Rolnego", 2014, nr 1 .

136 R. Budzinowski, Prawne pojęcie działalności pszczelarskiej, [w:] Prawo i Administracja, R. Budzinowski (red.), t. 2, Piła 2003; K. Różański, Prawne formy wsparcia działalności pszczelarskiej $w$ świetle rozporządzenia 1308/2013 ustanawiającego wspólna organizację rynków produktów rolnych, „Studia Iuridica Lublinensia”, 2017, t. 26, s. 445-454. 
standardy produkcji rolnej i żywnościowej, co z kolei przekłada się na bezpieczeństwo konsumentów.

Przykładem takiego instrumentu są normy handlowe obowiązujące zarówno wewnątrz UE, jak i podczas wywozu i przywozu produktów. Zgodnie z art. 73 rozporządzenia 1308/2013 wprowadza się je w celu zapewnienia, aby produkty spełniały normy higieniczne i zdrowotne, oraz w celu ochrony zdrowia zwierząt, roślin i ludzi. Normy te dzielą się na normy obowiązkowe oraz określenia zastrzeżone stosowane fakultatywnie w odniesieniu do produktów rolnych. Ich szczegółowa analiza wykracza poza ramy tego opracowania, ale dość wspomnieć, że ich niezachowanie uniemożliwia obrót produktem rolnym. Oznacza to istotną ingerencję w wolny rynek, gdzie zachowanie odpowiednich norm jest przesłanką do wejścia na niego lub pozostania na nim.

Mechanizm ten należy uznać za potrzebny z uwagi na przywołane cele związane $\mathrm{z}$ ochroną zdrowia i bezpieczeństwem konsumentów. Jednocześnie de lege ferenda należy postulować znaczne uproszczenie tych przepisów. Obecnie wielokrotne systemy odesłań powodują, że tekst ten jest wysoce niezrozumiały.

Jednym z ważnych instrumentów gwarantującym bezpieczeństwo oraz jakość produktów są nazwy pochodzenia, oznaczenia geograficzne i określenia tradycyjne ${ }^{137}$ w sektorze wina ${ }^{138}$. Pozwalają one odróżnić wina od innych napojów, które mogłyby być podobne.

Ostatnio obserwowalne choroby odzwierzęce, takie jak przykładowo ASF, ptasia grypa, czy choroba szalonych krów, wymusiły stworzenie mechanizmów pomocowych dla producentów rolnych, którzy stawali na skraju bankructwa. Zgodnie z rozporządzeniem nr 1308/2013 Komisja może wydawać akty wykonawcze przyjmujące nadzwyczajne środki wsparcia rynku dotkniętego trudnościami w celu uwzględnienia: ograniczeń dla handlu wewnątrz Unii i z państwami trzecimi, które to ograniczenia mogą wynikać ze stosowania środków zwalczania rozprzestrzeniania się chorób zwierząt, oraz poważnych zakłóceń na rynku, bezpośrednio związanych z utratą zaufania konsumentów spowodowaną zagrożeniami dla zdrowia ludzi, zdrowia zwierząt lub zdrowia roślin oraz ryzykiem chorób ${ }^{139}$.

Jest to kolejny nowy instrument prawny, który ma służyć zabezpieczeniu przed nagłymi zachwianiami rynku. Środki te mają zastosowanie do któregokolwiek spośród następujących sektorów: wołowiny i cielęciny; mleka i przetworów mlecznych; wieprzowiny; baraniny i koziny; jaj; mięsa drobiowego. Instrument ten należy doskonalić poprzez rozszerzenie katalogu możliwych chorób oraz zwiększenie budżetu

137 A. Baer-Nawrocka, A. Suchoń, Ochrona produktów regionalnych i tradycyjnych w Unii Europejskiej. Wybrane zagadnienia ekonomiczne i prawne, „Wieś i Rolnictwo”, 2014, nr 4, s. 115-130.

138 M. Śmiechowska, Autentyczność jako kryterium zapewnienia jakości żywności, „Annales Academiae Medicae Gedanensis", 2013, t. 43, nr 1.

139 I. Lipińska, Nadzwyczajne środki wsparcia jako prawna ochrona unijnego rynku rolnego, ,Przegląd Prawa Rolnego", 2017, t. 20, nr 1, s. 81-95. 
przeznaczonego na pomoc dla rolników. Jest on potrzebny w sytuacji, gdy rolnik pozostaje bez środków produkcji i z ekonomicznego punktu widzenia nie będzie w stanie konkurować na rynku.

Ważnym instrumentem prawnym w zakresie obrotu produktami rolnymi jest limitowanie - kwotowanie produkcji. Do niedawna system te obejmował przede wszystkim mleko. Jednakże w $2015 \mathrm{r}$. w odniesieniu do mleka zrezygnowano ${ }^{140} \mathrm{z}$ tego instrumentu ${ }^{141}$. Pozwalał on na kontrolę ilości produkowanego mleka.

Drugą branżą, której dotyczy limitowanie produkcji jest rynek cukru142. Tutaj utrzymano system kwot do 30 września 2017 r. Zgodnie z art. 134 ust. 1 rozporządzenia 1308/2013 system kwot miał zastosowanie do cukru, izoglukozy i syropu inulinowego. W przypadku jeżeli producent przekroczył przyznaną mu kwotę i nie wykorzystał nadwyżek, wnosił on opłatę z tytułu nadwyżek ${ }^{143}$. Oznacza to administracyjnoprawne ograniczanie ilości produkowanego towaru. Miało to istotny wpływ na konkurencyjność rolnictwa. Instrument ten powodował tworzenie sztucznych warunków cenowych, a także istotnie wpływał na cenę cukru.

\subsubsection{Organizacje i zrzeszenia producentów oraz organizacje międzybranżowe}

Ważnym instrumentem prawnym wpływającym na konkurencyjność rolnictwa są mechanizmy związane z zrzeszaniem się producentów. Służą temu nie tylko odpowiednie działania w polityce rozwoju obszarów wiejskich, ale także unormowania funkcjonujące na jednolitym rynku rolnym. Zgodnie z rozporządzeniem 1308/2013 można tworzyć organizacje i zrzeszenia producentów oraz organizacje międzybranżowe.

Jak wskazuje art. 152 ust. 1 rozporządzenia 1308/2013 państwa członkowskie mogą na wniosek uznawać organizacje producentów, które spełniają szereg warunków. Do jednych z nich należy powstanie z inicjatywy producentów i prowadzenie

140 Wprowadzono obowiązkowe deklaracje w sektorze mleka, zgodnie z którymi od 1 kwietnia 2015 r. pierwsze podmioty skupujące mleko surowe deklarują właściwemu organowi krajowemu ilość mleka surowego, którą im dostarczono każdego miesiąca. Na państwa członkowskie nałożono obowiązek powiadamiania Komisji o ilości skupionego mleka surowego.

141 A. Baer-Nawrocka, E. Kiryluk-Dryjska, Wptyw likwidacji kwot mlecznych na sytuacje produkcyjna i ekonomiczna producentów mleka w Unii Europejskiej (wyniki symulacji modelowych), „Wieś i Rolnictwo", 2010, nr 3; P. Szajner, Wpływ likwidacji kwot mlecznych i zmian regulacji rynku mleka na perspektywy rozwoju polskiego mleczarstwa, IERiGŻ, s. 12; P. Szajner, Ocena wplywu likwidacji kwot mlecznych na konkurencyjność polskiego mleczarstwa w kontekście teorii ekonomii, „Zeszyty Naukowe Szkoły Głównej Gospodarstwa Wiejskiego w Warszawie. Problemy Rolnictwa Światowego“, 2012, t. 27, nr 12, s. 104-112; B. Czyżewski, M. Śmigala, Instytucjonalne przesłanki rozwoju gospodarstw mleczarskich w Polsce, „Journal of Agribusiness and Rural Development”, 2012, t. 25, nr 3, s. 81-99.

142 P. Szajner, Wplyw reformy regulacji rynku cukru w UE na efektywność polskiego przemystu cukrowniczego, „Prace Naukowe Uniwersytetu Ekonomicznego we Wrocławiu”, 2012, nr 246, s. 444-453.

143 A. Budzyńska, Procesy restrukturyzacyjne charakteryzujące rynek cukru w Unii Europejskiej, „Problemy Rolnictwa Światowego”, 2013, nr 13. 
jednego z następujących rodzajów działalności lub większą ich liczbę: wspólne przetwarzanie; wspólna dystrybucja, w tym również wspólne platformy sprzedaży lub wspólny transport; wspólne pakowanie, etykietowanie lub promocja; wspólna organizacja kontroli jakości; wspólne wykorzystywanie urządzeń lub miejsc składowania; wspólne zarządzanie odpadami pochodzącymi bezpośrednio z produkcji; wspólne pozyskiwanie środków produkcji; wszelkie inne rodzaje wspólnej działalności usługowej prowadzone $\mathrm{z}$ myślą o realizacji jednego $\mathrm{z}$ celów wymienionych $\mathrm{w}$ rozporządzeniu ${ }^{144}$.

Dla funkcjonowania rynku możliwość tworzenia tego typu organizacji pozwala nie tylko osiągnąć lepszą pozycję negocjacyjną z dużymi odbiorcami, ale pozwala na szybsze przekazywanie innowacji know-how.

\subsubsection{Instrumenty funkcjonujące na jednolitym rynku w handlu z państwami trzecimi}

Podobnie jak na rynku wewnętrznym, tak i w handlu z państwami trzecimi obowiązuje szereg instrumentów prawnych wpływających na konkurencyjność rolnictwa. Dotyczą one utrzymywania nie tylko konkurencyjności rolnictwa całej UE względem państw trzecich, ale wpływają na konkurencyjność każdego państwa członkowskiego.

Mechanizmy, które można zaobserwować w handlu z państwami trzecimi dotyczą dwóch sfer. Jedne ochrony własnego rynku - temu służą mechanizmy interwencyjne. Drugie to normy jakościowe, jakie powinny spełniać produkty zarówno eksportowane, jak i importowane.

144 Inne wymogi to organizacje dążące do określonego celu, który może obejmować co najmniej jeden spośród następujących celów: zapewnienie planowania i dostosowywania produkcji do popytu, w szczególności w odniesieniu do jakości i ilości; koncentracja dostaw i umieszczanie na rynku produktów wytwarzanych przez ich członków, w tym sprzedaż bezpośrednia; optymalizacja kosztów produkcji i zysków z inwestycji służących utrzymywaniu standardów dotyczących ochrony środowiska i dobrostanu zwierząt oraz stabilizowanie cen producentów; prowadzenie badań i opracowywanie inicjatyw dotyczących zrównoważonych metod produkcji, innowacyjnych praktyk, konkurencyjności gospodarczej i rozwoju sytuacji rynkowej; promowanie i udzielanie pomocy technicznej w zakresie stosowania przyjaznych dla środowiska metod uprawy i technik produkcji oraz odpowiedzialnych praktyk i technik w odniesieniu do dobrostanu zwierząt; promowanie i udzielanie pomocy technicznej w zakresie stosowania standardów produkcji, poprawa jakości produktów i rozwijanie produktów o chronionej nazwie pochodzenia, chronionym oznaczeniu geograficznym lub objętych krajowym znakiem jakości; zarządzanie produktami ubocznymi i odpadami, zwłaszcza w celu ochrony jakości wody, gleby i krajobrazu oraz zachowania lub zachęcania do zachowania bioróżnorodności; przyczynianie się do zrównoważonego wykorzystania zasobów naturalnych oraz do łagodzenia zmiany klimatu; opracowywanie inicjatyw w dziedzinie promocji i wprowadzania do obrotu; zarządzanie funduszami wspólnego inwestowania, o których mowa w części poświęconej programom operacyjnym w sektorze owoców i warzyw, o których mowa w art. 33 ust. 3 lit. d) niniejszego rozporządzenia oraz w art. 36 rozporządzenia (UE) nr 1305/2013; udzielanie niezbędnej pomocy technicznej w celu korzystania z rynków terminowych i systemów ubezpieczeń. 
Podstawowym mechanizmem, który nie jest uregulowany w unormowaniach prawnorolnych jest $\mathrm{cło}^{145}$. Zastosowanie jednolitego taryfikatora celnego ${ }^{146}$ jest znanym od stuleci instrumentem prawnym, który wpływa na przepływ towarów oraz przez ich cenę na konkurencyjność. Trzeba zauważyć, że UE staje przed dużym wyzwaniem, jakim będzie napływ towarów w ramach zawartych umów z Kanadą i w mniejszym pewnie stopniu $\mathrm{z}$ Japonią ${ }^{147}$. Wyłączenie tego podstawowego mechanizmu prawnego w handlu z państwami trzecimi wydaje się rozwiązaniem ryzykownym.

Poniżej zostaną zaprezentowane tylko najważniejsze instrumenty prawne WPR, które wpływają na konkurencyjność rolnictwa poprzez handel z państwami trzecimi.

\subsubsection{Pozwolenia na przywóz i wywóz}

Jednym z mechanizmów interwencji w handlu z państwami trzecimi jest określanie co może być eksportowane i importowane. W tym zakresie w art. 176 ust. 1 rozporządzenia 1308/2013 wskazano, że pozwolenia na przywóz lub wywóz są wymagane na terenie całej Unii w odniesieniu do następujących produktów: zbóż; ryżu; cukru; nasion; oliwy z oliwek oraz oliwek stołowych, w odniesieniu do produktów objętych kodami CN 1509, 1510 00, 070992 90, 071120 90, 230690 19, 15220031 oraz 152200 39; Inu i konopi, w odniesieniu do konopi; owoców i warzyw; przetworzonych owoców i warzyw; bananów; wina; żywych roślin; wołowiny i cielęciny; mleka i przetworów mlecznych; wieprzowiny; baraniny i koziny; jaj; mięsa drobiowego; alkoholu etylowego pochodzenia rolniczego.

Pozwolenia obejmują zarówno eksport, jak i import wyżej wymienionych produktów. Wydają je państwa członkowskie według ściśle opisanej procedury w rozporządzeniu 1308/2013. Pozwolenia są ważne w całej Unii. Oznacza to, że towar dopuszczony do obrotu w jednym państwie członkowskim będzie mógł być przedmiotem już swobodnego obrotu w innych państwach. Wymaga to stosowania jednolitych zasad udzielania pozwoleń, a w szczególności stosowania odpowiednich procedur kontrolnych. Instrument ten ma nie tylko za zadanie określać ilość wwożonego lub wywożonego towaru, ale przede wszystkim ma zapewniać bezpieczeństwo konsumentom.

Komisja Europejska w aktach wykonawczych określa szczegółowe zasady udzielania pozwoleń, także ich odbierania oraz ważności. De lege ferenda należałoby wyraźnie określić wspólne ramy kwalifikacyjne dla podmiotów, którym są udzielane

145 J. Góral, Instrumenty wspierania gospodarstw rolniczych w Polsce, „Marketing i Zarządzanie”, 2016, nr 43, s. 57-69.

146 A. Kuś, P. Witkowski, Procedury celne w prawie celnym Unii Europejskiej, „Ius Novum”, 2019, t. 13, nr 1, s. 132-154; P. Witkowski, Instrumenty polityki celnej Unii Europejskiej, Lublin 2016.

147 Ł. Ambroziak, Potencjalny wplyw Umowy o partnerstwie gospodarczym UE - Japonia na polski handel rolno-spożywczy z Japonia, „Studia i Prace WNEiZ US”, 2018, t. 2, nr 53, s. 117-129. 
pozwolenia. Obecnie przedstawia się to dość zróżnicowanie w zależności od państwa członkowskiego ${ }^{148}$.

\subsubsection{Administrowanie kontyngentem taryfowym}

Ważnym instrumentem prawnym $\mathrm{w}$ handlu produktami rolnymi z państwami trzecimi jest określanie ilości eksportowanego i importowanego towaru. W tym celu w art. 184 ust. 1 rozporządzenia 1308/2013 wskazano, że kontyngenty taryfowe na przywóz produktów rolnych przeznaczonych do swobodnego obrotu w Unii lub jej części bądź kontyngenty taryfowe na przywóz unijnych produktów rolnych do państw trzecich, które mają być częściowo lub całkowicie administrowane przez Unię, wynikające z umów międzynarodowych zawartych zgodnie z TFUE lub z jakiegokolwiek innego aktu prawnego, są otwierane lub administrowane przez Komisję w drodze aktów delegowanych.

Limitowanie przywożonego i wywożonego towaru jest skutecznym mechanizmem, który wpływa na konkurencyjność. Pozwala na bezpośredni wpływ na rynek rolny. Umożliwia przykładowo wywożenie nadmiernej ilości produktów. Pozwala także na kontrolowanie jakości przywożonych produktów, gdyż w przyznanych kontyngentach można dokonać również takiego zastrzeżenia.

Należy zwrócić uwagę, że przyznawanie kontyngentów zostało scedowane na Komisję Europejską. Wydawanie aktów wykonawczych w tym trybie niezwykle wydłuża proces limitowania eksportu i importu. Nie pozwala to na reakcję w bieżącą sytuację na rynku. Szczególne zasady dotyczą rynku: konopi, chmielu, wina, cukru surowego do rafinacji.

\subsubsection{Refundacje wywozowe}

Według zasad preferencji europejskiej ważnym instrumentem są refundacje wywozowe. Zgodnie z art. 196 rozporządzenia 1308/2013 w zakresie niezbędnym do umożliwienia wywozu na podstawie notowań lub cen na rynkach światowych, gdy warunki na rynku wewnętrznym są takie, jak warunki opisane w rozporządzeniu, oraz w ramach limitów wynikających z umów międzynarodowych, zawartych zgodnie z TFUE, różnica między tymi cenami a cenami w Unii może zostać pokryta refundacjami wywozowymi. Dotyczy ona tylko wybranych produktów bez dalszego przetworzenia. Refundacje wywozowe obejmują: zboża; ryż; cukier; wołowinę i cielęcinę; mleko i przetwory mleczne; wieprzowinę; jaja; mięso drobiowe ${ }^{149}$.

148 A. Hajdukiewicz, Kierunki zmian w polskim eksporcie świeżych owoców $i$ warzyw $w$ kontekście embarga na przywóz niektórych produktów rolno-spożywczych do Rosji, „Przedsiębiorczość i Zarządzanie", 2018, nr 19, s. 81-92.

149 M. Tereszczuk, Subsydiowanie eksportu produktów rolno-spożywczych-zakres i znaczenie, „Finanse, Rynki Finansowe, Ubezpieczenia", 2016, nr 81, s. 225-235. 
Metoda rozdziału ilości, które mogą zostać wywiezione przy zastosowaniu refundacji wywozowej, to metoda rozdziału, która najlepiej odpowiada danemu typowi produktu i sytuacji na właściwym rynku oraz pozwala na możliwie najbardziej efektywne wykorzystanie dostępnych zasobów, mając na względzie wydajność i strukturę wywozu z Unii oraz ich wpływ na równowagę na rynku, nie doprowadzając jednak do dyskryminacji między zainteresowanymi podmiotami gospodarczymi, a w szczególności między dużymi i małymi podmiotami gospodarczymi ${ }^{150}$. Ponadto, refundację można zastosować za pomocą metody, która jest najmniej uciążliwa dla podmiotów gospodarczych z administracyjnego punktu widzenia, przy uwzględnieniu wymogów administracyjnych.

W całej UE za te same produkty stosuje się takie same refundacje wywozowe ${ }^{151}$. Zgodnie z art. 198 rozporządzenia 1308/2013 mogą się one różnić w zależności od miejsca przeznaczenia, w szczególności w przypadku, gdy jest to niezbędne ze względu na sytuację na rynku światowym, szczególne wymogi niektórych rynków lub zobowiązania wynikające z umów międzynarodowych zawartych zgodnie z TFUE.

\subsection{Mechanizmy prawne wynikające z soft law}

Nowym rodzajem instrumentów, które w sposób pośredni wpływają na konkurencyjność rolnictwa są mechanizmy prawne wynikające $\mathrm{z}$ soft law. Zazwyczaj są to akty wykonawcze Komisji Europejskiej, rezolucje Parlamentu Europejskiego, strategie, czy zalecenia. Mieszczą się one wszystkie w katalogu źródeł prawa europejskiego i służą koordynowaniu stanu legislacji w państwach członkowskich. Nie są jednakże aktami prawa o bezpośrednim skutku. Toteż opisane w nich instrumenty nie są automatycznie stosowane w państwach członkowskich. Przyjęte jednakże tam rozwiązania mają oddziaływać na prawodawstwo krajowe.

Przykładem takich unormowań są akty prawne dotyczące obrotu nieruchomościami. Co prawda nie jest to wprost określony cel WPR, ale do ochrony warsztatu pracy rolnika, kwalifikacji odnosi się szereg celów określonych w TFUE. Dlatego też poniższa analiza uwzględnia oddziaływanie proponowanych instrumentów na inne mechanizmy WPR.

Drugim ważnym rodzajem aktów prawnych są strategie i programy. Są one na tyle istotne, że akty prawne powszechnie obowiązujące europejskie i krajowe odwołują się do nich.

150 Art. 197 rozporządzenia 1308/2013.

151 M. Tereszczuk, Instrumenty polityki handlowej Unii Europejskiej a polski handel zagraniczny produktami rolno-spożywczymi, „Prace Naukowe Uniwersytetu Ekonomicznego we Wrocławiu”, 2016, nr 449, s. 627-638. 


\subsubsection{Obrót nieruchomościami rolnymi w świetle soft law}

Jednym z ważnych sektorów oddziaływania na konkurencyjność rolnictwa jest rynek ziemi rolnej. Nie dotyczy on tylko zmienności jej ceny, ale przede wszystkim dostępności tych nieruchomości dla rolników. Jest to o tyle ważne, że bez nich w aktualnym kształcie WPR rolnik właściwie nie może otrzymać żadnej pomocy finansowej. Co prawda przestaje ona mieć czynnik dominujący, ustępując specjalizacji i innowacji, ale nadal jest elementem podstawowym dla istnienia gospodarstw rolnych.

Regulacje na poziomie europejskim nie dotyczą własności ${ }^{152}$ nieruchomości ${ }^{153}$. Nie mogą jej ograniczać i ingerować w nią ${ }^{154}$. Skupiają się na głównej zasadzie traktatowej, czyli swobodzie przepływu kapitału. To regulacje krajowe określają reżim prawny oraz instrumenty prawne stosowane w obrocie nieruchomościami rolnymi. Nie istnieje żadne wspólnotowe prawo w tym zakresie. Nie jest zresztą możliwe aktualnie stworzenie odrębnej regulacji europejskiej z uwagi chociażby na odrębne regulacje cywilistyczne w każdym z państw członkowskich oraz wyłączność kompetencji państw członkowskich sprecyzowanych w art. 345 TFUE ${ }^{155}$. Przyznano to zresztą w cytowanej poniżej rezolucji Parlamentu Europejskiego wskazując w pkt 11, „że o ile polityka gruntowa leży zasadniczo w gestii państw członkowskich, mogą mieć na nią wpływ WPR lub odnośne obszary polityki, co z kolei wpływa poważnie na konkurencyjność gospodarstw rolnych na rynku wewnętrznym; jest zdania, że polityka gruntowa musi przyczyniać się do zapewnienia w stosownych ramach dużego, sprawiedliwego i równego rozproszenia własności gruntów, dostępu do ziemi oraz statusu dzierżawy gruntu, ponieważ ma to bezpośredni wpływ na warunki życia i pracy oraz jakość życia na wsi; zwraca uwagę na ważną społecznie funkcję własności gruntu i zarządzania gruntami przez pokolenia, jako że likwidacja gospodarstw i miejsc pracy prowadzi do upadku tradycyjnego rolnictwa europejskiego oraz obszarów wiejskich, a przez to w perspektywie ogólnospołecznej skutkuje niepożądanymi zmianami strukturalnymi”. W tym podejściu konkurencyjność zależy w dużej mierze od dostępności do gruntów rolnych.

152 A. Jurcewicz, Własność w ujęciu prawa wspólnotowego - zarys, „Studia Iuridica Agraria”, Białystok 2005, t. 5; por. także wyrok Trybunału w sprawie C-446/04, Test Claimants in the FII Group Litigation; C-17/03, VEMW; C-101/05, Skatteverket; C-243/01, Gambelli; C-169/07, Hartlauer; C-333/14, Scotch Whiskey C-446/04, Test Claimants in the FII Group Litigation; C-182/03 oraz C-217/03, Forum 187; C-182/83, Fearon; C-452/01, Ospelt; C-370/05, Festersen; C-302/97, Konle; sprawy połączone C-515/99-C-524/99 oraz C-526/99-C-540/99, Reisch; C-423/98, Albore.

153 A. Lichorowicz, Problematyka prawna harmonizacji polskiej regulacji obrotu gruntami rolnymi $z$ ustawodawstwem Unii Europejskiej w przedmiocie struktur agrarnych, [w:] II Kongres notariuszy Rzeczypospolitej Polskiej. Referaty i opracowania, Poznań - Kluczbork 1999, s. 157-172.

154 M. Szewczyk, Ingerencja publicznoprawna w prawo własności jednostki w demokratycznym państwie prawnym, [w:] Jednostka w demokratycznym państwie prawa, J. Filipek (red.), Bielsko-Biała 2003.

155 A. Jurcewicz, Przemiany własności w rolnictwie - kontekst systemowy z perspektywy prawa krajowego i unijnego, „Studia Prawnicze”, 2014, nr 1. 
W ostatnich jednakże latach można zaobserwować wydawanie aktów prawnych o charakterze soft law, które obejmują swoim zakresem obrót nieruchomościami. Określają w drodze „miękkiego” prawa mechanizmy prawne, które można recypować do regulacji krajowych. Każde z państw członkowskich ma swój reżim prawny i instrumenty prawne, które określają dostępność gruntów rolnych dla rolników. Bardzo duża część z tych krajowych legislacji preferuje rolników, jako głównych nabywców ziemi rolnej. Przykładem takiego ustawodawstwa jest polska ustawa o kształtowaniu ustroju rolnego. Instrumenty prawne preferujące rolników, jako właścicieli nieruchomości rolnych mają także przykładowo inne państwa, ${ }^{156}$ takie jak Francja, Włochy, czy Hiszpania ${ }^{157}$.

Jednym $z$ takich dokumentów, który na większą skalę zapoczątkował dyskusje o kształcie obrotu nieruchomościami rolnymi w Europie jest rezolucja Parlamentu Europejskiego z dnia 27 kwietnia 2017 r. w sprawie aktualnego stanu koncentracji gruntów rolnych w UE: jak ułatwić rolnikom dostęp do gruntów? ${ }^{158}$. Rezolucja ta ma wskazać kierunek przekształceń unormowań krajowych, aby zapobiec kilku niekorzystnym zjawiskom na rynku ziemi rolnej. Takie zjawiska jak koncentracja, czy spekulacja gruntami ${ }^{159} \mathrm{z}$ pewnością są niekorzystne dla konkurencyjności rolnictwa. Podkreślono to w rezolucji wskazując, ,że w 2013 r. zaledwie 3,1\% gospodarstw w UE-27 kontrolowało 52,2\% powierzchni użytków rolnych w Europie, natomiast 76,2\% gospodarstw posiadało jedynie $11,2 \%$ gruntów rolnych; mając na uwadze, że tendencja ta jest sprzeczna $\mathrm{z}$ europejskim modelem zrównoważonego, wielofunkcyjnego rolnictwa, którego ważny element stanowią gospodarstwa rodzinne; [...] że pod względem nierówności w użytkowaniu gruntów stawia to UE, w której współczynnik Giniego wynosi 0,82 , na jednym poziomie z krajami, takimi jak Brazylia, Kolumbia i Filipiny; [...] że temu nierównemu podziałowi gruntów rolnych towarzyszy nierówny podział dotacji przyznawanych $w$ ramach WPR, ponieważ płatności bezpośrednie stanowiące największą część wydatków w ramach WPR są zasadniczo wypłacane od hektara".

Należy jednakże podkreślić, że istnieją państwa świata, takie jak chociażby USA ${ }^{160}$, gdzie gospodarstwa duże zyskują specjalne preferencje. Dlatego też istnieją rozwinięte

156 D. Stankiewicz, Ograniczenia $w$ obrocie gruntami rolnymi $w$ wybranych krajach Unii Europejskiej $w$ aspekcie prac nad stosownymi zmianami $w$ ustawodawstwie polskim, „BAIS”, 2002, nr 886, s. 4-7.

157 P. Blajer, Ewolucja szczególnej regulacji obrotu gruntami rolnymi w ustawodawstwie hiszpańskim, „Studia Iuridica Agraria”, Białystok 2009, t. 9, s. 107-125.

158 Zob. http://www.europarl.europa.eu/sides/getDoc.do?pubRef=-//EP//TEXT+TA+P8-TA-20170197+0+DOC+ XML+V0// PL\&language=PL [data dostępu 30 marca 2019 r.].

159 Odzwierciedlone jest to w pkt 3 rezolucji Parlamentu Europejskiego. Parlament „uważa, że państwa członkowskie powinny regularnie przekazywać pozostałym państwom członkowskim i Komisji informacje o ustawodawstwie krajowym w zakresie gruntów, zmian w użytkowaniu gruntów, a przede wszystkim o przypadkach spekulacyjnych zakupów gruntów".

160 P. Blajer, Gospodarstwa rodzinne w USA - status, znaczenie $i$ aktualne problemy, „Studia Iuridica Agraria”, Białystok 2014, t. 12, s. 97-119; P. Blajer, Amerykańskie family farms: status i instrumenty wspierania przez instytucje federalne, [w:] Prawne mechanizmy wspierania i ochrony rolnictwa rodzinnego w Polsce i innych państwach Unii Europejskiej, P. Litwiniuk (red.), Warszawa 2015, s. 311-324. 
gospodarki, gdzie właściwie prowadzona koncentracja gruntów nie będzie oceniana jako zjawisko negatywne. W Europie jednakże, gdzie czynnik ziemi nadal ma bardzo duże znaczenie, nadmierna koncentracja gruntów będzie oceniana jako zjawisko niekorzystne dla konkurencyjności rolnictwa. Podkreśla się to przykładowo w pkt 31 rezolucji Parlamentu Europejskiego, gdzie wskazano, że „konieczne jest wprowadzenie pułapów i ukierunkowywanie płatności bezpośrednich tak, aby nadać większą wagę pierwszym hektarom oraz ułatwiać inwestycje i przyznawanie pomocy bezpośredniej małym gospodarstwom rolnym; zachęca Komisję do wprowadzenia bardziej skutecznego mechanizmu redystrybucji pomocy w celu uniknięcia koncentracji gruntów". Powstaje zasadnicze pytanie, czy taki mechanizm wspierający małe gospodarstwa, który jest jak najbardziej zasadny z punktu widzenia polityki społecznej, będzie spełniał odpowiednie wymogi ekonomicznej skuteczności.

Europa wspierająca gospodarstwa rodzinne i USA coraz bardziej subwencjonujące duże gospodarstwa mogą przynieść zupełne inne efekty ekonomiczne. Mogą także oferować konsumentom inne produkty rolne i spożywcze.

W rezolucji przewidziano szereg instrumentów prawnych, których wprowadzenie do systemu prawa krajowego powinno skutecznie przeciwdziałać opisanym zjawiskom. W wyniku ich zastosowania powinno nastąpić zachowanie rolnego charakteru nieruchomości, a przez to rozwój gospodarstw małych i średnich.

Do jednego z głównych instrumentów prawnych, mających być kryterium dostępu do ziemi rolnej, są kwalifikacje rolnicze. Analizowane powyżej mechanizmy PROW w ten sam sposób akcentują wymogi chociażby w poddziałaniu „Premia dla młodego rolnika”. Podkreśla się to w pkt 33 rezolucji Parlamentu Europejskiego. Wskazano w nim ,znaczenie jednoznacznej w całej Unii definicji pojęcia «aktywny rolnik», która jest jednoznacznie powiązana z pojęciem pracy w gospodarstwie rolnym i która dokonuje dokładnego rozróżnienia gruntów kwalifikowalnych i niekwalifikowalnych (np. lotniska, otwarte obszary przemysłowe, pola golfowe); wzywa Komisję do dopilnowania, by beneficjentami bezpośredniego wsparcia byli wyłącznie aktywni rolnicy". Oznacza to, że preferowanym nabywcą nieruchomości rolnych w UE mają być aktywni rolnicy ${ }^{161}$. Zgodnie z tym instrumentem, ziemię rolną będą mogli nabywać tylko profesjonaliści prowadzący działalność rolniczą ${ }^{162}$. W Polsce określono także uprawnienia

161 Zgodnie z art. 9 rozporządzenia 1307/2013 „Osobę lub grupę osób objętych zakresem akapitu pierwszego lub drugiego, uważa się jednak za rolnika aktywnego zawodowo, jeżeli za pomocą możliwych do zweryfikowania dowodów, w formie wymaganej przez państwa członkowskie, udokumentuje ona, że:

a) roczna kwota płatności bezpośrednich wynosi co najmniej 5\% całości przychodów uzyskanych przez nią z działalności pozarolniczej w ostatnim roku obrotowym, za który dowody takie są dostępne;

b) jej działalność rolnicza nie ma charakteru marginalnego; lub

c) jej główną działalność gospodarczą lub przedmiot działalności stanowi wykonywanie działalności rolniczej”.

162 P. Liwtiniuk, O wybranych problemach dotyczacych zakresu wyłaczeń spod nowego reżimu prawnego obrotu nieruchomościami rolnymi w Polsce, ,Studia Iuridica Lublinensia”, 2017, t. 26, s. 256-269. 
rolnika indywidualnego ${ }^{163}$. Musi on posiadać odpowiednie kwalifikacje w celu możliwości spełniania ustawowych wymogów nabywania nieruchomości rolnych. Kwalifikacje rolnicze kwestionowane jako kryterium dostępu do nieruchomości rolnych są kwestionowane jednakże w innym dokumencie o charakterze soft law - Komunikacie Komisji Europejskiej z dnia 18 października 2017 r. „Komunikat wyjaśniający Komisji w sprawie nabywania gruntów rolnych i prawa Unii Europejskiej"164. W komunikacie Komisji w zakresie kwalifikacji rolniczych wskazano, że „W związku z tym nie można stwierdzić, że dla skutecznego funkcjonowania sektora rolnego obowiązkowo wymaga się posiadania kwalifikacji zawodowych. W tym kontekście wymóg posiadania określonych kwalifikacji w celu zakupu gruntów wymaga szczególnego uzasadnienia w przepisach krajowych; w przypadku braku takiego uzasadnienia wydawałoby się, że wymóg jest nieuzasadnionym i nieproporcjonalnym ograniczeniem swobodnego przepływu kapitału. Aby wysnuć inny wniosek, państwa członkowskie musiałyby wykazać, dlaczego wymaga się określonych kwalifikacji do zakupu gruntów, podczas gdy zasadniczo dopuszcza się prowadzenie działalności rolniczej bez jakiegokolwiek formalnego potwierdzenia kompetencji. Wnioski te nie podważają faktu, że pomyślne i zrównoważone rolnictwo wymaga odpowiedniego szkolenia zawodowego".

Do innych tego typu instrumentów prawnych, które oddziałują na funkcjonowanie obrotu rolnego zalicza się: normy obszarowe, kryterium dochodowości (wspomniane zresztą w definicji rolnika aktywnego zawodowo) ${ }^{165}$, kryterium doświadczenia (pracy) w rolnictwie, kryterium obywatelstwa ${ }^{166}$. Instrumenty te wpływają na kształt obrotu nieruchomościami rolnymi w danym państwie. Łącznie mogą stanowić istotne ograniczenie dostępności do nieruchomości rolnych nie tylko dla spekulantów, ale przede wszystkim dla rolników. Oddziałują także na ceny ziemi rolnej, a tym samym na konkurencyjność rolnictwa.

Problem naruszenia przez ten instrument zasady proporcjonalności znany jest nie tylko w prawie europejskim ${ }^{167}$, ale także w prawie polskim ${ }^{168}$. Istnienie dwóch doku-

163 P. Blajer, Koncepcja prawna rolnika indywidualnego w prawie polskim na tle porównawczym, Kraków 2009.

$164 \mathrm{https}: / /$ eur-lex.europa.eu/legal-content/PL/TXT/?uri=CELEX\%3A52017XC1018\%2801\%29 [data dostępu 30 marca 2019 r.].

$165 \mathrm{~W}$ pkt 30 rezolucji PE wprowadza się także odniesienie dochodowe. Parlament Europejski „,Zwraca uwagę na możliwości stojące przed państwami członkowskimi w zakresie zmniejszenia części płatności bezpośrednich przekraczającej górny limit 150000 EUR o co najmniej 5\%, jak przewidziano w art. 11 rozporządzenia (UE) nr 1307/2013 (zwanym dalej rozporządzeniem w sprawie płatności bezpośrednich)".

166 K. Marciniuk, Prawne instrumenty ingerencji władzy publicznej w obrót nieruchomościami rolnymi jako środki kształtowania ustroju rolnego, Białystok 2019, s. 228 i nast.

167 A. Krasuski, M. Kloepfer, Die Entfaltung des Verhältnismäßigkeitsprinzips, [w:] Festgabe 50 Jahre Bundesverwaltungsgericht E. Schmidt-Aßmann (red.), Köln 2003, s. 329-346; W. Krebs, Zur verfassungsrechtlichen Verortung und Anwendung des Übermaßverbotes, „Jura”, 2001, s. 228-234.

168 Wyroki Trybunału Konstytucyjnego P 2/98, s. 16; K 13/98, s. 372; SK 9/98, s. 409; por. także J. Zakolska, Zasada proporcjonalności w orzecznictwie Trybunatu Konstytucyjnego, Warszawa 2008, s. 18 i nast. 
mentów typu soft law, które w odmienny sposób regulują zalecenia w stosunku do jednego z podstawowych instrumentów prawnych, może okazać się w dhuższej perspektywie zgubne dla funkcjonowania rolnictwa europejskiego. Państwa członkowskie po lekturze chociażby informacji o tym mechanizmie prawnym nie będą w stanie określić możliwego zakresu podejmowanych rozwiązań prawnych. Stan taki należy uznać za wysoce nieodpowiedzialny. Może on być prezentowany w ramach dyskusji pomiędzy instytucjami europejskimi, ale nie w dokumentach prawnych, które w założeniu mają wyznaczać przyszłość europejskiego rolnictwa. Po ich lekturze nie wiadomo, które $\mathrm{z}$ instrumentów prawnych są zalecane, ani tym bardziej, które poprawią konkurencyjność.

Jednym z podstawowych mechanizmów oddziałujących na obrót nieruchomościami rolnymi rezolucja wymienia zarządzanie gruntami rolnymi poprzez mechanizmy planistyczne. W rezolucji Parlament Europejski zachęca państwa członkowskie do takiego kształtowania zagospodarowania przestrzennego, aby zachować jak największą część gruntów o charakterze rolnym. Przykłady zastosowania tego instrumentu można zaobserwować w Polsce poprzez analizę definicji nieruchomości rolnej zawartej ustawie o kształtowaniu ustroju rolnego. Zgodnie z tym przepisem, reżimem obrotu nieruchomościami rolnymi nie są objęte tylko te nieruchomości (z pewnymi wyjątkami), które są przeznaczone w planach zagospodarowania przestrzennego na cele inne niż rolne ${ }^{169}$. Zakotwiczenie obrotu nieruchomościami rolnymi w aktach planowania przestrzennego wyraźnie wskazuje na wysoce interwencyjny charakter tego instrumentu prawnego. To władza publiczna może decydować, które nieruchomości są objęte specjalnym reżimem, a które nie poprzez ustanawianie przykładowo miejscowych planów zagospodarowania przestrzennego ${ }^{170}$. Jest to złożony instrument prawny, który zależny jest od przyjętych aktów planistycznych w danym państwie członkowskim.

Ingerencja administracyjnoprawna powinna odbywać się także poprzez odpowiednie wyspecjalizowane podmioty. Określono je w pkt 25 rezolucji. Parlament „domaga się, aby państwa członkowskie wspierały lub utworzyły - przy udziale państwa

169 K. Marciniuk, Pojęcie nieruchomości rolnej jako przedmiotu reglamentacji obrotu własnościowego, „Studia Iuridica Lublinensia”, 2017, t. 26, s. 94-114; A. Lichorowicz, Regulacja obrotu gruntami rolnymi wedlug ustawy z 11 kwietnia 2003 roku o ksztaltowaniu ustroju rolnego na tle ustawodawstwa agrarnego Europy Zachodniej, „Studia Iuridica Agraria”, Białystok 2005, t. 4, s. 7-30; Nieruchomości rolne w praktyce notarialnej, P. Księżak, J. Mikołajczyk (red.), Warszawa 2017.

170 Z. Truszkiewicz, Wpływ planowania przestrzennego na pojęcie nieruchomości rolnej $w$ rozumieniu Kodeksu cywilnego, „Studia Iuridica Agraria”, Białystok 2007, t. 6; J. Goździewicz-Biechońska, Planowanie przestrzenne wobec wspótczesnych tendencji rozwoju obszarów wiejskich, „Przegląd Prawa Rolnego", 2015, nr 2; A. Suchoń, Wplyw miejscowego planu zagospodarowania przestrzennego na prawne formy dysponowania nieruchomościami rolnymi, „Studia Iuridica Agraria”, Białystok 2016, t. 14, s. 131-146; B. Wierzbowski, Aspekty przestrzenne ksztaltowania ustroju rolnego, „Studia Iuridica Agraria”, Białystok 2016, t. 14, s. 29-46; A. Niewiadomski, Rola aktów planistycznych w obrocie nieruchomościami rolnymi, [w:] Księga Jubileuszowa ku czci profesor Teresy Kurowskiej ,Wspótczesne problemy prawa rolnego i cywilnego”, D. Łobos-Kotowska (red.), Katowice 2018, s. 419-429. 
i pod nadzorem publicznym - odpowiednie organy zajmujące się zarządzaniem ziemią". W Polsce taką instytucją jest Krajowy Ośrodek Wsparcia Rolnictwa (KOWR), w Hiszpanii była IRYDA, we Francji SAFER, Enti di Sviluppo Agrario ${ }^{171}$. Jednostki te mogą np. wydawać administracyjnoprawne pozwolenia na dokonanie danej transakcji na rynku nieruchomości rolnych. Takie uprawnienia ma m.in. KOWR. Poza dysponowaniem Zasobem Własności Rolnej Skarbu Państwa (ZWRSP) ${ }^{172}$ może dyrektor generalny KOWR wydawać pozwolenia na nabywanie nieruchomości rolnych przez podmioty, które nie są rolnikami indywidualnymi ${ }^{173}$. Oczywiście pozwolenia te stanowią istotne ograniczenia w obrocie nieruchomościami rolnymi, a zarazem ograniczają prawo ich własności ${ }^{174}$.

Podejście zezwoleń administracyjnych ${ }^{175}$ jako instrumentu prawnego kreującego rynek obrotu nieruchomościami jest krytykowane w komunikacie Komisji. Wskazano w nim, że ,z orzecznictwa można wywnioskować, że uzależnienie przeniesienia prawa własności gruntów rolnych od uzyskania uprzedniego zezwolenia administracyjnego ogranicza swobodny przepływ kapitału, choć w pewnych okolicznościach taka zasada może być jednak uzasadniona na mocy prawa Unii”. To kolejny przykład dwugłosu unijnych instytucji co do wyboru konkretnych mechanizmów prawnych oddziałujących na rynek rolny. Stwarza to niepewność na rynku. Ona jest najgroźniejszym przeciwnikiem wzrostu konkurencyjności.

Udział samorządów w obrocie nieruchomościami odpowiada także postulatowi większego uczestniczenia władz lokalnych w kształtowaniu zrównoważonego rolnictwa. W rezolucji znajdują również odzwierciedlenie instrumenty prawne związane $\mathrm{z}$ ochroną środowiska i klimatu. W pkt 36 rezolucji wskazano, iż ,ziemia jest ograniczonym zasobem, który z powodu zmiany klimatu, erozji gleby i nadmiernego wykorzystywania lub zmiany sposobu wykorzystania znajduje się już pod silną presją, i dlatego popiera środki eko-społeczne na rzecz ochrony gleby i jednocześnie podkreśla, że ziemia należy do wyłącznych kompetencji państw członkowskich”. Oznacza to możliwość wprowadzenia instrumentów prawnych, które nie tylko będą chroniły dostęp do zasobów cennych przyrodniczo, lecz także stawiały jako kryterium dostępu do nieruchomości wymogi związane z instrumentami ekologicznymi. Do takich

171 Por. szerzej K. Marciniuk, Prawne instrumenty ingerencji władzy publicznej w obrót nieruchomościami rolnymi ..., dz. cyt., s. 295-303.

172 S. Prutis, Formy prawne dysponowania Zasobem Własności Rolnej Skarbu Państwa, [w:] Prawo rolne, A. Stelmachowski (red.), Warszawa 2006, s. 217; E. Tomkiewicz, Sprzedaż państwowych nieruchomości rolnych $w$ aspekcie ulepszania struktur rolnych, „Wieś i Rolnictwo”, Warszawa 1994, nr 1, s. $115-129$.

173 J. Pisuliński, O niektórych osobliwościach obrotu nieruchomościami rolnymi, „Rejent”, 2016, nr 5, s. 44 i nast.

174 M. Budzikowski, Ograniczenia praw podmiotowych wtaściciela nieruchomości rolnej w prawie administracyjnym, „Studia Iuridica”, 2014, nr 58, s. 31-43.

175 Nieruchomości rolne w praktyce notarialnej, P. Księżak, J. Mikołajczyk (red.), Warszawa 2017. 
instrumentów można chociażby zaliczyć praktyki korzystne dla klimatu z polityki zazieleniania.

Tego typu rozwiązaniom, które będą łączyć dwa nowe podejścia do WPR, czyli środowisko i innowacyjność, służy zalecenie wyrażone w pkt 20 rezolucji. Parlament Europejski „zachęca państwa członkowskie do angażowania się w większym stopniu $\mathrm{w}$ transfer wiedzy poprzez projekty w dziedzinie badań i innowacji w celu poprawy jakości gleby dzięki stosowaniu praktyk rolnośrodowiskowych". Połączenie tych instrumentów prawnych będzie jednym z podstawowych mechanizmów finansowanych w przyszłej WPR. Jednocześnie na tym przykładzie można zaobserwować, jak przy niezmienianych celach WPR powstają nowe instrumenty prawne, które te cele mają realizować.

Pewną nowością w odniesieniu do prawa polskiego jest rozciągnięcie zalecanych mechanizmów na dzierżawę gruntów rolnych ${ }^{176}$. Zgodnie z pkt 12 rezolucji Parlament Europejski „wzywa państwa członkowskie, aby w celu osiągnięcia założeń WPR przy nabywaniu i dzierżawie gruntów rolnych przyznawały pierwszeństwo drobnym i średnim producentom lokalnym, nowym podmiotom i młodym rolnikom, zapewniając równy dostęp kobietom i mężczyznom, ponieważ posiadanie jak największej części uprawianej przez nich ziemi jest w interesie zrównoważonego i stabilnego rozwoju ich gospodarstw, zwłaszcza w czasach, kiedy podmioty niebędące rolnikami są coraz bardziej zainteresowane nabywaniem działek rolnych, bardzo często w celach czysto spekulacyjnych; zachęca państwa członkowskie do promowania małych rodzinnych gospodarstw rolnych i zrównoważonych metod produkcji”. Dzierżawa staje się ważnym czynnikiem kształtowania obrotu nieruchomościami rolnymi. Dość wspomnieć, że w skład gospodarstwa rodzinnego, zdefiniowanego w ustawie o kształtowaniu ustroju rolnego zalicza się także grunty dzierżawione ${ }^{177}$. Określone wymogi w rezolucji mogłyby stać się ważnym zaleceniem dla przyszłej WPR w zakresie jej uproszczenia. Dzierżawa staje się także znaczącym instrumentem oddziaływania na konkurencyjność rolnictwa ${ }^{178}$.

176 P. Czechowski, A. Lichorowicz, Dzierżawa gruntów rolnych w świetle standardów europejskich, „Podatki i Prawo Gospodarcze Unii Europejskiej”, 1999, nr 6, s. 2; A. Lichorowicz, Dzierżawa gruntów rolnych $w$ ustawodawstwie krajów zachodnioeuropejskich (studium prawno-porównawcze), „Zeszyty Naukowe Uniwersytetu Jagiellońskiego", Warszawa, Kraków 1986, z. 118; J. Szydłowski, B. Szydłowska, Zmiany $w$ strukturze obszarowej gospodarstw rolnych oraz dzierżawa i sprzedaż ziemi, [w:] Przemiany strukturalne $w$ gospodarce żywnościowej regionu. Materiały konferencyjne, Barzkowice 1994, s. 36-42; W. Ziętara, Rola dzierżawy nieruchomości rolnych w procesie przemian struktury obszarowej gospodarstw rolniczych w Polsce, „Roczniki Akademii Rolniczej w Poznaniu”, 1999, nr 268, s. 267; W. Pańko, Dzierżawa gruntów rolnych, Warszawa 1975.

177 A. Lichorowicz, Dzierżawa gruntów rolnych, [w:] Prawo rolne, A. Stelmachowski (red.), Warszawa 2009, s. 187-203; A. Suchoń, Dzierżawa gruntów rolnych a rozwój obszarów wiejskich, „Studia Iuridica Agraria", Białystok 2007, t. 6, s. 90-106.

178 B. Tańska-Hus, Dzierżawa rolnicza jako instrument przeksztalceń strukturalnych $w$ rolnictwie, Wrocław 2000; A. Suchoń, Dzierżawa gruntów rolnych jako instrument kształtowania ustroju rolnego, „Studia Iuridica Agraria”, Białystok 2005, t. 4, s. 199-211. 
W rezolucji PE można wyłuskać także wizję przyszłej WPR oraz stosowanych w niej instrumentach prawnych. Przykładowo, w pkt 28 rezolucji Parlament Europejski ,sugeruje [...] by Komisja przyjęła zalecenia w sprawie gospodarowania gruntami w UE zgodnie z dobrowolnymi wytycznymi i z uwzględnieniem horyzontalnych unijnych ram w sprawie rolnictwa, środowiska, rynku wewnętrznego i spójności terytorialnej”. Oznacza to zalecenie do przyjmowania preferencji w zakresie ochrony środowiska. Rynek wewnętrzny, który jest kojarzony dotychczas z instrumentami inwestycyjnymi staje się dopiero kolejnym ogniwem w przyszłej WPR.

Parlament także wskazuje na kierunek rozwoju takich instrumentów prawnych jak płatności bezpośrednie. W pkt 32 ,zachęca państwa członkowskie, aby w większym stopniu korzystały z dostępnego już zakresu ograniczania i redystrybucji funduszy WPR, np. możliwości przeznaczenia 30\% płatności bezpośrednich na pierwszy hektar w celu wzmocnienia małych i rodzinnych gospodarstw, pod warunkiem że przestrzegają one jednocześnie wymogów art. 41 i 42 rozporządzenia w sprawie płatności bezpośrednich; proponuje, aby korzystniejsze traktowanie pierwszych hektarów było wyliczane nie w odniesieniu do gospodarstwa, a jednostki dominującej; domaga się zatem, aby Komisja, przestrzegając zasad ochrony danych, publikowała informacje dotyczące nie tylko o właścicielach gospodarstw, którzy otrzymują dotacje $w$ ramach WPR, ale i beneficjentów takich jak właściciele gruntu czy jednostki dominujące". Oznacza to dalsze utrzymywanie preferencji dla małych gospodarstw o charakterze rodzinnym. Jednocześnie pogłębia to stosowaną dyskryminację dla gospodarstw większych i wielkotowarowych. Rozumiejąc politykę społeczną utrzymywania gospodarstw rodzinnych może okazać się, że presji konkurencyjnej nie będą w stanie wytrzymać duże gospodarstwa, pozbawione wsparcia. Ich problemy ekonomiczne pociągną spadek konkurencyjności całego sektora rolnego.

Można to zaobserwować na rynku jabłek w Polsce. Wielkie zakłady przetwarzające jabłka popadając $\mathrm{w}$ kłopoty finansowe przede wszystkim poprzez politykę embarga wobec Rosji nie mogą zaoferować odpowiednio wysokich cen skupu jabłek. Powoduje to gigantyczne problemy tej branży i nieopłacalność produkcji. Bankructwo jednego dużego gospodarstwa pociąga za sobą zakończenie działalności kilkudziesięciu małych. Dlatego też wsparcie finansowe i konstruowane instrumenty finansowe powinny uwzględniać równomierne rozłożenie pomocy finansowej na wszystkie podmioty na rynku.

Przedstawione wybrane instrumenty prawne z dwóch aktów prawnych typu soft law pokazują zróżnicowane podejście do obrotu nieruchomościami rolnymi w Europie. Określenie tych zasad w państwach członkowskich stanowi podstawowy, ważny czynnik uzyskiwania jakiejkolwiek pomocy finansowej pochodzącej z funduszy europejskich. Bez nieruchomości rolnych producent rolny po prostu nie otrzyma żadnej pomocy. Dlatego też utrzymanie dostępności gruntów rolnych dla rolników wydaje się zadaniem kluczowym. 
Trzeba jednakże wypracować takie mechanizmy prawne, które będą godziły trzy sprawy. Po pierwsze, będą chroniły rolny charakter nieruchomości, uniemożliwiając tym samym przeznaczanie jej na cele inne niż rolne. Po drugie, nie będą ingerowały w europejską zasadę swobody przepływu kapitału. Po trzecie, nie będą naruszały istoty prawa własności. Dopiero spełnienie tych wszystkich kryteriów pozwoli na zaprezentowanie takich instrumentów prawnych, które mogą okazać się skuteczne. Nie będą one liczne, ale najważniejsze, aby były efektywne.

Analizowane dokumenty typu soft law nie spełniają zadania wyznaczania przyszłości obrotu nieruchomościami rolnymi w Europie. Po pierwsze, są zbyt ogólne, a przez to pozwalają na różną interpretację. Po drugie, nawzajem się wykluczają. Rezolucja Parlamentu Europejskiego zaleca posiadanie kwalifikacji rolniczych przy nabywaniu nieruchomości, a komunikat Komisji Europejskiej go zabrania. To tylko przykład takiego podejścia. Niestety, z prezentowaną przez te dokumenty wizją obrotu nieruchomościami rolnymi konkurencyjność rolnictwa nie wzrośnie, a raczej wywołany chaos prawny tylko utrudni dotychczasowy, i tak już skomplikowany obrót nieruchomościami rolnymi.

\subsubsection{Instrumenty wynikające ze strategii i programów europejskich i krajowych}

Jednym z przywoływanych dokumentów w PROW 2014-2020 jest Strategia „Europa 2020"179. Strategia ta jest wprowadzona do systemu prawa Komunikat Komisji w dokumencie $\operatorname{COM}(2010) 2020$ z dnia 3 marca 2010 r. ${ }^{180}$. Dotyczy ona przede wszystkim kwestii zatrudnienia, ale także inteligentnego i zrównoważonego rozwoju sprzyjającego włączeniu społecznemu ${ }^{181}$. Wspomina się o nim również w takich działaniach PROW, jak LEADER, gdzie efekty programu są oceniane poprzez wkład w realizację celów Europa $2020^{182}$. Wiążą się z nią także instrumenty oddziałujące na klimat, gdyż Strategia zakłada redukcję emisji gazów cieplarnianych o co najmniej 20\% w porównaniu do poziomów z roku 1990 lub nawet o 30\% przy sprzyjających warunkach, wzrost udziału energii odnawialnej w całkowitym zużyciu energii do $20 \%$, oraz osiągnięcie $20 \%$ wzrostu w efektywnym wykorzystaniu energii.

Cele tej Strategii odnoszą się także do konkurencyjności. Jednym z nich jest większy nacisk na badania i rozwój oraz innowacje, w połączeniu z efektywniejszym wykorzystywaniem energii, podniesie konkurencyjność UE, co przyczyni się

179 Zob. https://ec.europa.eu/info/business-economy-euro/economic-and-fiscal-policy-coordination/ eu-economic-governance-monitoring-prevention-correction/european-semester/framework/europe2020-strategy_pl [data dostępu 30 marca 2019 r.].

180 Zob. http://ec.europa.eu/eu2020/pdf/1_PL_ACT_part1_v1.pdf [data dostępu 30 marca 2019 r.].

181 Komunikat Komisji z dnia 3 marca 2010 r. Europa 2020. Strategia na rzecz inteligentnego i zrównoważonego rozwoju sprzyjającego właczeniu społecznemu, KOM (2010) 2020

182 PROW 2014-2020, s. 709. 
do powstawania nowych miejsc pracy. Ponadto, zgodnie ze strategią inwestowanie w czystsze technologie ułatwi walkę ze zmianami klimatu, a jednocześnie stworzy nowe możliwości rozwoju dla przedsiębiorstw i pracowników ${ }^{183}$. Szczegółowe instrumenty prawne wynikające ze strategii są określane w regulacjach krajowych.

Strategia jest przykładem dokumentu o charakterze soft law, który poprzez założone cele oddziałuje na funkcjonowanie unormowań krajowych. Instrumenty prawne tam określone wpływają na konkurencyjność całej gospodarki, ale także rolnictwa. Strategia ta stanowi zasadniczy element integracji europejskiej w obecnym okresie programowania.

Do tej Strategii odwołuje się Strategia na Rzecz Odpowiedzialnego Rozwoju do 2020 r. (z perspektywą do 2030 r.) ${ }^{184}$. Strategia ta jest formalnie uchwałą Rady Ministrów, a co za tym idzie nie znajduje się w katalogu źródeł prawa powszechnie obowiązującego. Stanowi jednakże podstawę do określania instrumentów prawnych, które z niej wynikają ${ }^{185}$. W Strategii ROR wskazano na podstawowe cele. Są to przede wszystkim trwały wzrost gospodarczy oparty na dotychczasowych i nowych przewagach; rozwój społecznie i terytorialnie wrażliwy; skuteczne państwo i instytucje gospodarcze służące wzrostowi społecznemu i gospodarczemu. Wzrost gospodarczy określony w ostatnim celu ma odnosić się także do sektora rolnego.

Kilka instrumentów, które przewidziano w Strategii ROR to wsparcie rozwoju społecznej funkcji gospodarstw rolnych, łączącej rolnictwo wielofunkcyjne i usługi o charakterze społecznym (lub zdrowotnym) na poziomie lokalnym, umożliwiające dywersyfikację dochodów rolników połączoną z szerszą ofertą usług socjalnych dla osób starszych i niepełnosprawnych ${ }^{186}$. Oznacza to wdrażanie instrumentów o charakterze społecznym, przede wszystkim w odniesieniu do sektora zdrowia na terenach wiejskich.

Zakłada się wprowadzenie technologii mobilnych, które mogą wspierać rolnictwo w czterech obszarach: poprawie dostępności do usług finansowych, dostarczeniu istotnych informacji dla rolnictwa, poprawy efektywności łańcucha dostaw, zwiększeniu dostępności do rynku. W tym zakresie przewidziano specjalne instrumenty prawne, które mają zrealizować te cele. Zaliczono do nich mLearning (pozyskanie wiedzy na temat technik i trendów rolniczych, informacji dotyczących uprawy roślin), czy $\mathrm{mFarming} \mathrm{(optymalizacja} \mathrm{upraw} \mathrm{rolnych} \mathrm{przy} \mathrm{dostępnych} \mathrm{technologiach} \mathrm{na} \mathrm{podstawie}$

183 D.S. Kozłowski, Strategia zrównoważonego rozwoju Unii Europejskiej i jej implikacje dla Polski, „Biuletyn Polskiego Klubu Ekologicznego”, 2004.

$184 \mathrm{https}$ :/powietrze.gios.gov.pl/pjp/documents/download/102570m [data dostępu 30 marca 2019 r.]; Uchwała nr 8 Rady Ministrów w sprawie przyjęcia Strategii na rzecz Odpowiedzialnego Rozwoju do roku 2020 (z perspektywą do 2030 r.) (M.P. 2017 poz. 260) - dalej ROR.

185 M.A. Król, Instrumenty ochrony środowiska i tadu przestrzennego na obszarach wiejskich w Strategii na Rzecz Odpowiedzialnego Rozwoju w kontekście procesu integracji europejskiej, [w:] Integracja europejska jako determinanta polityki wiejskiej. Aspekty prawne, P. Litwiniuk (red.), Warszawa 2017.

186 Strategia ROR, s. 164-165. 
danych mikroklimatycznych) ${ }^{187}$. Tego typu rozwiązania z pewnością wpisują się w innowacyjność WPR, na którą nacisk jest położony w perspektywie po $2020 \mathrm{r}$. Niewątpliwie polscy rolnicy będą musieli przedsięwziąć szereg przygotowań, aby te systemy spełniały swoje funkcje i przynosiły efekty wpływające na konkurencyjność rolnictwa.

Wiele instrumentów prawnych przewidziano w Strategii ROR dotyczących ochrony środowiska, czy korzystania z zasobów wodnych. Wszystkie one w przyszłości muszą zostać wprowadzone do polskiej legislacji. Obecnie stanowią podstawę ubiegania się o fundusze nakreślone w Strategii ROR cele. Ich szczegółowa analiza wykracza poza ramy niniejszego opracowania 188 .

Strategie te zarówno na poziomie europejskim, jak i krajowym wyznaczają jedynie cele, które należy osiągnąć. Konkretne instrumenty prawne są definiowane w aktach prawa powszechnie obowiązującego. Są to zazwyczaj rozporządzenia europejskie i krajowe ustawy. Jako akty prawa o charakterze soft law są tworzone także w dużym stopniu ogólności. Można również na ich przykładzie zaobserwować dobieranie odpowiednich instrumentów do realizacji poszczególnych celów. Wybór konkretnych mechanizmów to zbieg decyzji politycznych i finansowych w danym okresie.

\subsection{Instrumenty prawne wpływające na konkurencyjność rolnictwa w wybranych państwach europejskich}

Instrumenty prawne WPR wpływające na konkurencyjność nie są adresowane tylko do Polski. Korzystają z nich także inne państwa członkowskie UE. Dobór poszczególnych instrumentów z polityki rozwoju obszarów wiejskich jest zależny od każdego państwa członkowskiego. Państwa kierują się przy tym analizą ex ante oraz analizą SWOT. Wybierają tylko te mechanizmy określone w rozporządzeniu 1305/2013, które są potrzebne dla ich sektorów rolnych.

187 Strategia ROR, s. 293.

188 Konkurencyjność i wprowadzenie odpowiednich mechanizmów prawnych została zasygnalizowana w Strategii ROR na s. 182: „Polityka regionalna będzie dążyła do zapewnienia bardziej zrównoważonego rozwoju kraju poprzez zintegrowane interwencje wykorzystujące miejscowe zasoby i potencjały poszczególnych terytoriów i dostarczanie odpowiednich zasobów dla zainicjowania trwałego wzrostu i miejsc pracy w obszarach o mniej korzystnych uwarunkowaniach rozwojowych. Obok działań wzmacniających konkurencyjność wszystkich regionów, miast oraz obszarów wiejskich realizowanych w dotychczasowym układzie wdrożeniowym, szczególne mechanizmy wsparcia zostaną zaproponowane dla obszarów problemowych, które zmagają się z trudnościami adaptacyjnymi i restrukturyzacyjnymi, zarówno na poziomie regionalnym - takich jak Polska Wschodnia, Śląsk, jak również dla subregionalnych obszarów funkcjonalnych, o kumulacji negatywnych zjawisk społeczno-gospodarczych - dla obszarów przeważnie wiejskich zagrożonych trwałą marginalizacją oraz miast średnich tracących funkcje społeczno-gospodarcze. Zakres i sposób wsparcia będą uzależnione od specyfiki danego terytorium i obejmą działania służące aktywizacji gospodarczej, rozwojowi lokalnych rynków pracy i mobilizacji zawodowej mieszkańców oraz poprawie dostępu do usług publicznych”. 
Mechanizmy prawne wynikające $\mathrm{z}$ organizacji jednolitego rynku rolnego i z rozporządzenia 1308/2013 są wspólne dla wszystkich państw członkowskich. W rozporządzeniu przewidziano pewne odrębne instrumenty dla poszczególnych sektorów. Przykładowo, można tutaj podać sektor wina, który najbardziej charakterystyczny jest we Francji. Instrumenty te wpływają na obrót tymi produktami. Jednakże ich zastosowanie nie jest bezpośrednio zależne od państw członkowskich.

Podobnie reguły dotyczące płatności bezpośrednich są zbliżone w zależności od wyboru rodzaju płatności (do hektara lub produkcji). Dlatego też główne analizy dotyczą pewnych różnic $\mathrm{w}$ instrumentach prawnych wynikających z polityki rozwoju obszarów wiejskich. Obecnie istnieje 118 programów rozwojów obszarów wiejskich w 28 państwach UE.

Przedstawione poniżej wybrane instrumenty prawne w niektórych państwach UE mają pokazać obraz pewnych odmienności od prezentowanych mechanizmów wybranych w Polsce. Dobór państw był podyktowany ich specyfiką rolną, a także wielkością otrzymywanej pomocy.

\subsubsection{Francja}

Szczegółowy program Krajowej Sieci Obszarów Wiejskich we Francji został przyjęty przez Komisję Europejską w dniu 13 lutego 2015 r. ${ }^{189}$. Ma on dwa poziomy narodowy - gdzie są mechanizmy prawne właściwe dla całego kraju, oraz kantonalny z instrumentami prawnymi charakterystycznymi dla poszczególnych regionów. Głównym celem PROW we Francji, na który przeznaczona zostanie połowa środków finansowych, jest rozwój lokalnej produkcji rolnej w celu poprawy bezpieczeństwa żywnościowego. Program wspiera projekty modernizacyjne i rozwojowe dla około $10 \%$ gospodarstw, 40 projektów młodych rolników w celu zagwarantowania odnowienia pokoleń i szkolenia dla ponad 2000 producentów. Około 18\% środków programu zostanie wykorzystanych na poprawę podstawowych usług na obszarach wiejskich, aby dotrzeć do 75\% ludności korzystającej z ulepszonych usług i infrastruktury, w ramach której zostanie zrealizowanych 18 projektów badawczych i inwestycyjnych związanych z obszarami wiejskimi ${ }^{190}$.

Do instrumentów na poziomie krajowym należą takie działania jak wspieranie transferu wiedzy i innowacji w sektorach rolnictwa i leśnictwa, a także na obszarach wiejskich, czy poprawa rentowności gospodarstw rolnych i konkurencyjności wszystkich rodzajów rolnictwa we wszystkich regionach oraz promowanie innowacyjnych technologii rolniczych i zrównoważonej gospodarki leśnej. Niewątpliwie w tym

$189 \mathrm{https} / /$ ec.europa.eu/agriculture/sites/agriculture/files/rural-development-2014-2020/country-files/fr/press-summary-13-02-2015_en.pdf [data dostępu 30 marca 2019 r.].

190 Tamże. 
ostatnim działaniu następuje dość silne akcentowanie konkurencyjności gospodarstw rolnych niezależne od ich specyfiki produkcyjnej.

Inne działania na poziomie krajowym to promowanie organizacji łańcucha żywnościowego, w tym przetwórstwa i marketingu produktów rolnych, dobrostanu zwierząt i zarządzania ryzykiem w sektorze rolnym, czy przywracanie, ochrona i wzmacnianie ekosystemów związanych z rolnictwem i leśnictwem. Działaniem, które również jest działaniem proekologicznym jest promowanie efektywnego wykorzystania zasobów i wspieranie przejścia na gospodarkę niskoemisyjną i odporną na zmiany klimatu w sektorach rolnym i spożywczym oraz w sektorze leśnym.

We francuskim PROW przewidziano także instrumenty o charakterze społecznym takie jak chociażby promowanie włączenia społecznego, ograniczenie ubóstwa i rozwój gospodarczy na obszarach wiejskich. Działania te w większym stopniu zostały wyeksponowane we Francji, niż w polskim PROW. Wydaje się, że mają one coraz większe znaczenie dla kształtu rolnictwa rozwiniętego i spełniającego wymogi jego konkurencyjności.

Tak jak wspomniano we Francji obowiązują także programy lokalne zależne od danego kantonu. Przykładowo, w Burgundii realizując rozporządzenie 1305/2013 wybrano 19 rodzajów mechanizmów prawnych wsparcia. Należą do nich m.in. takie działania, jak: „Transfer wiedzy i działania informacyjne”; „Usługi konsultingowe, usługi pomocy w zarządzaniu gospodarstwem rolnym i usługi alternatywne”; „Inwestycje fizyczne”; „Rozwój gospodarstw rolnych i przedsiębiorstw”; „Podstawowe usługi i rewitalizacja wsi na obszarach wiejskich”; „Inwestycje w rozwój obszarów leśnych i poprawę żywotność lasów”; „Środowisko rolne - klimat”; „Rolnictwo ekologiczne”; „Płatności w ramach sieci Natura 2000 i Ramowej Dyrektywy Wodnej”, „Płatności na obszary podlegające ograniczeniom naturalnym lub innym szczególnym ograniczeniom”; ,W Współpraca”. Każde z tych działań ma określone wybrane poddziałania, które są charakterystyczne dla danego kantonu.

$\mathrm{Z}$ tej poglądowej analizy już na wstępie wynika, czy można by de lege ferenda rozważyć wprowadzenie zróżnicowania regionalnego w polityce rozwoju obszarów wiejskich także w Polsce. Być może szczegółowe analizy specyfiki danych obszarów podyktowałby wybór innych mechanizmów wsparcia. Rozwiązania te mogłyby przyczynić się do wzrostu konkurencyjności.

\subsubsection{Republika Federalna Niemiec}

Podobny mechanizm zróżnicowania programów rozwojów obszarów wiejskich w zależności od regionu wybrały Niemcy. Przykładowo, w Kraju Saary wybrano instrumenty prawne korzystne $\mathrm{z}$ punktu widzenia tego regionu ${ }^{191}$. Wybrano w tym

$191 \mathrm{https} / /$ www.saarland.de/dokumente/thema_landwirtschaft/SEPL_2014-2020_5.0.pdf [data dostępu 30 marca 2019 r.]. 
landzie 14 podstawowych działań. Do najważniejszych należą: „Inwestycje w rzeczowe aktywa trwałe”; ,Rozwój gospodarstw rolnych i innych przedsiębiorstw”; „Podstawowe usługi i odnowa wsi na obszarach wiejskich”; „Inwestycje w rozwój obszarów leśnych i poprawę rentowności lasów”; „Środowisko rolne i klimatyczne”; „Rolnictwo ekologiczne”; „Płatności w ramach sieci Natura 2000 i ramowej dyrektywy wodnej”; „Płatności dla obszarów szczególnych z przyczyn naturalnych lub innych szczególnych”; „Wsparcie rozwoju lokalnego LEADER”. Są one sprecyzowane przede wszystkim pod potrzeby lokalnych rolników. Konstrukcja tych mechanizmów odpowiada reżimowi opisanemu w rozporządzeniu 1305/2013.

Na poziomie krajowym w niemieckim PROW jako główne działania wskazano: „Inwestycje w rzeczowe aktywa trwałe”; „Rekonstrukcja potencjału produkcji rolnej zniszczonego w wyniku klęsk żywiołowych i wprowadzenie odpowiednich środków zapobiegawczych”; „Rozwój gospodarstw rolnych i innych przedsiębiorstw”; „Podstawowe usługi i odnowa wsi na obszarach wiejskich”; „Inwestowanie w rozwój obszarów leśnych i poprawę rentowności lasów"; Działania rolnośrodowiskowe i klimatyczne”; „Rolnictwo ekologiczne”; „Płatności dla obszarów o niekorzystnych warunkach gospodarowania ze względów naturalnych lub innych szczególnych” 192 .

Wybór poszczególnych instrumentów prawnych pozostał w gestii landów, które poprzez ministerstwo rolnictwa prowadzą procedurę ustalania programów rozwojów obszarów wiejskich z Komisją Europejską. Takie podejście pozwala na elastyczne kształtowanie konkurencyjności rolnictwa i wypracowanie rzeczywiście potrzebnych instrumentów prawnych. Aktualne priorytety rozwoju obszarów wiejskich opierają się na następujących długoterminowych celach strategicznych: promowanie konkurencyjności przemysłu rolnego, leśnego i spożywczego; zapewnienie zrównoważonego zarządzania zasobami naturalnymi i ochroną klimatu, jak również zrównoważony rozwój przestrzenny gospodarki wiejskiej i obszarów wiejskich. Konkurencyjność nadal w Niemczech jest jednym z wyznaczników sektora rolnego oraz udzielanej pomocy.

\subsubsection{Wielka Brytania}

Jednym z ważnych rolniczych państw UE o specyficznych warunkach prowadzenia działalności rolniczej jest Wielka Brytania. Co prawda zamierza ona zakończyć udział w UE, ale aktualny stan prawny pozwala nadal oceniać instrumenty prawne stosowane do subwencjonowania angielskiego rolnictwa. Wielka Brytania ma 4 oddzielne programy rozwojów obszarów wiejskich dla Anglii, Irlandii Północnej, Szkocji i Walii. Pozwala to na uwzględnienie specyfiki każdego z tych regionów wynikającej z warunków naturalnych, czy tradycji rolnictwa.

192 https://www.bmel.de/SharedDocs/Downloads/Landwirtschaft/LaendlicheRaeume/NRR-20142020.pdf;jsessionid=AF68A475B7D65C254B01DD030A80DDB6.1_cid376?_blob=publicationFile [data dostępu 30 marca 2019 r.]. 
Przykładowo, PROW w Szkocji zawiera 15 działań, które wybrano z instrumentów prawnych oferowanych w rozporządzeniu 1305/2013. Do najważniejszych można zaliczyć działania: „Transfer wiedzy i działania informacyjne”; „Usługi doradcze, zarządzanie gospodarstwem i usługi pomocy dla gospodarstw rolnych”; „Systemy jakości produktów rolnych i środków spożywczych”; , Inwestycje w środki trwałe”; „Rozwój gospodarstwa i biznesu”; „Podstawowe usługi i odnowa wsi na obszarach wiejskich”; „Inwestycje w rozwój obszarów leśnych i poprawę rentowności lasów”; „Działania rolno-środowiskowo-klimatyczne”; „Rolnictwo ekologiczne”; „Płatności na obszary podlegające ograniczeniom naturalnym lub innym szczególnym ograniczeniom”; „Dobrostan zwierząt”; „Usługi leśne w zakresie środowiska i klimatu oraz ochrony lasów”; „Współpraca”; „Wsparcie rozwoju lokalnego LEADER (CLLD rozwój lokalny kierowany przez społeczność)"193.

Jednym z rzadko stosowanych działań jest dobrostan zwierząt. Pozwala on zachować przede wszystkim troskę o zwierzynę w lasach. Pozwala także na zachowanie obszarów leśnych oraz bioróżnorodności. Przykład tego działania jest efektem wyboru w unormowaniach szkockich instrumentu prawnego odpowiedniego dla tamtejszego sektora rolnego.

\subsubsection{Hiszpania}

Państwem podobnym wielkością do Polski jest Hiszpania. Specyficzne warunki klimatyczne sprzyjają jednakże rozwojowi zupełnie innych produktów rolnych niż w Polsce. Dlatego też dobór mechanizmów w hiszpańskim PROW zależy od lokalnego rolnictwa. Poza PROW na poziomie krajowym istnieje 17 regionalnych programów.

Przykładowo, w Katalonii jako podstawowe instrumenty wsparcia wybrano takie mechanizmy, jak: „Działania transferu wiedzy i informacji”; „Systemy jakości produktów rolnych i spożywczych”; „Inwestycje w środki trwałe”; „Rozwój działalności rolniczej i gospodarczej”; „Podstawowe usługi i odnowa populacji na obszarach wiejskich”; „Inwestycje w rozwój obszarów leśnych i poprawę rentowności lasów”; „Tworzenie grup i organizacji producentów”; „Agrośrodowisko i klimat”; „Rolnictwo ekologiczne”; „Płatności na rzecz obszarów z naturalnymi ograniczeniami lub innymi szczególnymi ograniczeniami”; „Współpraca”; „Wsparcie rozwoju lokalnego LEADER (DLP - rozwój lokalny uczestniczący)"194.

Przykładowo, jednym z poddziałań w ramach „Płatności na rzecz obszarów z naturalnymi ograniczeniami lub innymi szczególnymi ograniczeniami” jest „Poprawa gospodarki wodnej, w tym zarządzanie nawozami i pestycydami”"195. Oznacza to

$193 \mathrm{https} / / /$ www2.gov.scot/Resource/0054/00544562.pdf [data dostępu 30 marca 2019 r.].

$194 \mathrm{http}$ //agricultura.gencat.cat/web/.content/09-desenvolupament-rural/programa-desenvolupament-rural/periode-2014-2020/enllacos-documents/fitxers-binaris/170831_programa_desarrollo_rural_ catalunya_2014_2020_versio_6_1.pdf [data dostępu 30 marca 2019 r.].

195 Tamże, s. 705. 
szczególną ochronę rolnictwa, środowiska i konsumentów. Pokazuje to także pewne różnice w podejściu do rolnictwa i zarządzania nim pomiędzy państwami tzw. starej 15 a takimi państwami, jak Polska.

\subsection{Podsumowanie}

Przedstawione w tym rozdziale instrumenty prawne WPR w różny sposób wpływają na konkurencyjność rolnictwa. Wszystkie jednak tworzą system połączonych mechanizmów prawnych, które w znacznym stopniu poprawiają dochodowość gospodarstw rolnych. Można również zaobserwować odchodzenie od instrumentów typowo interwencyjnych (przykładem jest tutaj drastyczne ograniczenie interwencji publicznej) w kierunku instrumentów o charakterze społecznym czy środowiskowym.

Zmiana ta będzie również widoczna w przyszłości. Aktualnie trwające prace nad WPR po 2020 r. nie zmieniły jej celów. Trwa tylko poszukiwanie instrumentów prawnych, ale także finansowych, jakimi te cele można zrealizować. Dokonana analiza pozwala na wysunięcie kilku wniosków.

Aktualne regulacje preferują przede wszystkim małe i średnie gospodarstwa. Wniosek ten znajduje zarówno odzwierciedlenie w PROW, czy unormowaniach dotyczących rynków rolnych, ale także chociażby w rezolucji Parlamentu Europejskiego dotyczącej dostępu do gruntów. Ogólnie popierając ten kierunek jako wspierający stronę słabszą ekonomicznie i innowacyjnie, trzeba się zastanowić nad mechanizmami prawnymi, które umożliwiłyby wsparcie także w duże gospodarstwa rolne. Ich wyniki finansowe także decydują o konkurencyjności rolnictwa. Problem ten zyskuje na znaczeniu, kiedy obserwujemy reakcje prawne na pojawiające się choroby odzwierzęce. Pomoc kierowana tylko do małych rolników, oczywiście jest potrzebna, bo bez niej sobie oni nie poradzą, ale należy także pomyśleć o dużych gospodarstwach rolnych. Oni także, a może przede wszystkim będą ponosili konsekwencje przykładowo wybicia hodowanej trzody chlewnej. Nie będzie to dotyczyć kilkuset zwierząt, ale kilku, czy kilkunastu tysięcy. Taka sytuacja znacznie bardziej będzie oddziaływać na konkurencyjność rolnictwa. Pozostawienie tej co prawda nielicznej grupy rolników bez pomocy, biorąc pod uwagę powierzchnię na jakiej gospodarują, w dłuższej perspektywie może okazać się niebezpieczne.

Jednym z warunków dobrze funkcjonujących instrumentów prawnych jest równe traktowanie wszystkich uczestników rynku. Obecne mechanizmy prawne preferujące w większości przypadków tylko gospodarstwa małe nie spełnią testu niedyskryminacji. Jest to problem ogólny. Dotyczy wielu analizowanych mechanizmów. Można się zgodzić, że istnieją specjalne programy wsparcia dla małych i średnich gospodarstw. Nie ma jednakże prawie żadnej alternatywy dla gospodarstw wielkopowierzchniowych - rozumianych zazwyczaj jako te o powierzchni 50 ha. De lege ferenda należy postulować w przyszłej perspektywie finansowej zachowanie równowagi związanej 
ze sprawiedliwym traktowaniem uczestników rynku. Trzeba zwrócić także uwagę, że przykładowo w USA to duże gospodarstwa zyskują subsydia publiczne, podczas gdy mniejsze muszą w dużej części radzić sobie o własnych siłach. Powoduje to istnienie nierównowagi konkurencyjnej pomiędzy dużymi gospodarstwami w Europie a tymi w Stanach Zjednoczonych.

Dokonana analiza wskazała także na odchodzenie od mechanizmów typowo inwestycyjnych w kierunku zabezpieczenia społecznego rozumianego jako oddziaływanie na zasoby pracy. Przykładem może być szereg instrumentów prawnych kierowanych dla młodych rolników. Wynikają one zarówno z PROW, jak i systemu płatności bezpośrednich. Tendencja ta próbuje połączyć wymogi inwestowania w rolnictwo, z oddziaływaniem na strukturę wiekową rolników aktywnych zawodowo. Mechanizmy te pozostawiają jednak dość dużą grupę rolników poza sferą możliwości uzyskiwania pomocy. Dość wspomnieć, że w Polsce istnieje duża liczba rolników, którzy nie korzystają z najprostszej formy wsparcia, jaką są płatności bezpośrednie. Trzeba zdiagnozować przyczyny takiego stanu rzeczy i spróbować temu zaradzić. Uważam, że mnożenie wymogów wstępnych, jak zasady wzajemnej zgodności, zazielenienie, młodemu rolnikowi nie będzie służyło.

Uproszczenie WPR w świetle dokonanych badań wydaje się niezbędną potrzebą. Powstają nie tylko wątpliwości prawne, które zostały wskazane przy każdym analizowanym instrumencie, ale przede wszystkim wielość wymogów odstrasza potencjalnych beneficjentów od starania się o pomoc. Ten skomplikowany system w połączeniu z dość niskimi zachętami finansowymi może zahamować realizację celów WPR. Rolnikom może się bardziej opłacać prowadzić intensywne rolnictwo, produkować na dużą skalę, z wykorzystaniem sztucznych nawozów, niż przestrzegać instrumentów prawnych WPR. Wzrost konkurencyjności rolnictwa może nastąpić, ale nie będzie to wtedy zasługą polityki europejskiej, ale rolników, którzy w bieżącym, w miarę pewnym zysku będą widzieli realną szansę dla siebie, niż w wymogach prośrodowiskowych czy klimatycznych.

W odniesieniu do tego ostatniego zagadnienia zaobserwowano wzrost znaczenia instrumentów prawnych, które zrównują wymogi dotyczące konkurencyjności rolnictwa z wymogami środowiskowymi. Uważam to za słuszną drogę. Problem tylko tkwi w zbyt dużej liczbie instrumentów, które w jednym okresie rolnik powinien zastosować, aby móc ubiegać się o stosowną pomoc. Pojawiają się także problemy skoordynowania obowiązujących aktów krajowych z wymogami określanymi przez poszczególne instrumenty prawne. Przykład powołany w analizowaniu wymogów rolno-środowiskowo-klimatycznych i ich możliwej kolizji z formami ochrony przyrody, takimi jak parki czy obszary Natura 2000 jest dość jaskrawy.

Dbanie o klimat i środowisko musi być w przyszłości wyznacznikiem każdej polityki UE, nie tylko rolnej. Trzeba jednakże uczynić wszystko, aby rolnikom zaproponować wystarczającą zachętę do stosowania tych zasad, a nie wprowadzać kary czy niezbyt precyzyjnie określone obowiązki. Instrumenty te muszą zostać 
przeanalizowane pod kątem ich skuteczności. Zbyt duża liczba wymogów może przynieść odwrotny efekt. Już dziś rolnicy obliczają czy na terenach cennych przyrodniczo bardziej się opłaca skorzystać z pomocy finansowej UE, czy też posadzić wierzbę wysokoenergetyczną i zapłacić odpowiednią karę. Rachunek ekonomiczny coraz bardziej przemawia za tym drugim rozwiązaniem. Toteż należy postulować nie tylko uproszczenie instrumentów, edukację potencjalnych beneficjentów, ale także zwiększenie finansowania oferowanej pomocy.

Trzeba także zauważyć, że coraz większego znaczenia nabierają instrumenty prawne, które są określane w dokumentach typu soft law. Należą do nich nie tylko różnego rodzaju rozporządzenia wykonawcze Komisji Europejskiej, ale także rezolucje, komunikaty, strategie. Te trzy ostatnie kategorie nie są wprost wiążące dla rolników. Wynikające jednak z nich postanowienia są analizowane w państwach członkowskich. Prowadzi to niejednokrotnie do zmian legislacyjnych, których zadaniem jest ujednolicenie stosowanych instrumentów prawnych, które znajdują się w gestii krajów członkowskich. Przykładem tego mogą być chociażby dokumenty wskazujące na instrumenty prawne mogące obowiązywać w obrocie nieruchomościami. Tego typu podejście trzeba przyjmować z ostrożnością.

Zanalizowane instrumenty prawne pozwoliły na wskazanie wielu szczegółowych postulatów de lege ferenda. Mogą one być tym cenniejsze z uwagi na nowe podejście do określania mechanizmów prawnych w projektowanej WPR po 2020 r. Większość szczegółowych instrumentów prawnych ma być określana na poziomie krajowym. Wymusza to intensywne prace legislacyjne, przede wszystkim w obszarze polityki rozwoju obszarów wiejskich. Wybór odpowiednich instrumentów prawnych będzie przesądzał o konkurencyjności nie tylko całego europejskiego rolnictwa na rynku światowym, ale także krajowych sektorów rolnych na rynku wspólnotowym. Określenie tych instrumentów prawnych będzie skutkowało określeniem kształtu polskiego rolnictwa na najbliższe kilka lat. Zły ich dobór może doprowadzić do bankructwa przede wszystkim małych rolników oraz tych, którzy pozostaną bez pomocy państwa w sytuacjach kryzysowych związanych z chorobami odzwierzęcymi. 


\section{Zakończenie}

Zaprezentowane w pracy rozważania oraz wyniki prowadzonych badań nad instrumentami prawnymi WPR wpływających na konkurencyjność rolnictwa prowadzą do szeregu zróżnicowanych wniosków. Część z nich została zaprezentowana w końcowych podsumowaniach poszczególnych rozdziałów. Opierają się one na obserwacji coraz silniejszego związku unormowań prawnych zależnych od wyników ekonomicznych. To, w jakim kierunku ewoluuje dana instytucja prawna zależy w dużej mierze od efektów ekonomicznych, jakie osiąga w kolejnych okresach programowania.

Analizowane instrumenty prawne WPR są jedynie mechanizmami „usługowymi” dopasowywanymi do osiągnięcia określonego celu. Traktatowe cele WPR są niezmienne od dziesięcioleci. Natomiast krótkookresowe cele finansowe podlegają zmianom. Połączenie tych dwóch podejść określania celów z punktu widzenia legislacji oraz przez pryzmat ekonomicznych wyników, wzbogaconych o czynnik społeczny, określa obecnie kształt i treść stosowanych instrumentów prawnych mających wpłynąć pozytywnie na konkurencyjność rolnictwa.

Ta generalna uwaga wyraźnie wskazuje na przedstawienie kolejnych tez rozprawy. Cele WPR pozostają niezmienne, jedynie usuwane są instrumenty prawne, które z punktu widzenia legislacyjnego i ich konstrukcji prawnych, nie przetrwały próby czasu z uwagi na nieosiągnięcie wymaganych wskaźników ekonomicznych. Pojęcie konkurencyjności nie zdefiniowane $\mathrm{w}$ prawie europejskim jest związane $\mathrm{z}$ oceną ekonomicznej efektywności. W tym zakresie dobór poszczególnych instrumentów prawnych jest determinowany zakładanymi wynikami finansowymi, dochodowymi, czy szerzej zwiększającymi konkurencyjność. Ten stan ma doprowadzić do realizacji celów WPR, czyli poprawy bytu rolników.

Problemem jest, że ogólne cele traktatowe WPR są odczytywane w każdym okresie programowania inaczej. Ustala się na poziomie europejskim, ale także krajowym kolejne instrumenty prawne, aby je dopasować do zakładanych celów. Brak dłuższej stabilności tych instrumentów jest ich główną wadą. Rolnik nie może dziś planować swojej działalności w dłuższej perspektywie, niż ta, którą określają ramy finansowe UE. Powodem tego stanu rzeczy jest niemożność przewidzenia, jakie będą wymogi w kolejnym okresie programowania, nie tylko dla bardzo specjalistycznych instrumentów, ale dla tych najbardziej podstawowych, takich jak przykładowo płatności bezpośrednie. W tym ostatnim przypadku sytuacja staje się jeszcze bardziej skomplikowana przy analizie niektórych założeń, wyrażonych w aktach prawnych typu soft law, dotyczących ich likwidacji. Sytuacja niepewności prawnej i gospodarczej 
poprzez zmianę polityki finansowania rolnictwa stwarza największe niebezpieczeństwo dla wzrostu konkurencyjności rolnictwa.

Sformułowane poniżej tezy rozprawy odnoszą się do postawionych we wstępie hipotez badawczych. Przy wykorzystaniu metody dogmatycznej, historycznoprawnej prawnoporównawczej oraz ekonomicznej analizy prawa udało się dowieść założeń postawionych na początku badań. Najważniejsze tezy wynikające $\mathrm{z}$ dysertacji to:

1. Udowodniono, że fundusze europejskie powodują wzrost konkurencyjności polskiego rolnictwa poprzez zastosowanie odpowiednich instrumentów prawnych. Zarówno globalna analiza stosowanych mechanizmów, jak i poszczególne instrumenty, przede wszystkim inwestycyjne, takie jak modernizacja gospodarstw rolnych, wskazały na poprawę dochodowości gospodarstw rolnych. Ta poprawa powoduje wzrost konkurencyjności. Przez ostatnie 15 lat środki finansowe skierowane na rolnictwo z pewnością poprawiły jego wskaźniki ekonomiczne. Można to zauważyć chociażby przy wykorzystaniu najpopularniejszego miernika osiąganych celów, jakim jest wskaźnik GVA. Jeżeli rolnik wykaże co najmniej $10 \%$ wzrost wartości ekonomicznej, to uznaje się, że instrument przyniósł oczekiwany efekt.

Jednocześnie istnieją mechanizmy prawne, których ocena skutków ekonomicznych jest utrudniona lub niemożliwa. Trudno dziś ocenić, jaki jest efekt ekonomiczny działania renty strukturalnej. Poza umożliwieniem zmiany pokoleniowej w rolnictwie nie można wskazać wymiernych efektów tego typu instrumentów. $Z$ tego też względu mechanizmy tego typu są wycofywane. Oznacza to, że analizy ex ante i ex post nie przyniosły takich samych efektów. $\mathrm{Z}$ pewnością problemem tego typu mechanizmów są także częste ich zmiany. Przez kilka lat istnienia rent strukturalnych w Polsce warunki ich otrzymywania były zmieniane w każdym naborze. Takie podejście nie sprzyja podejmowaniu ważnych decyzji o zakończeniu działalności rolniczej.

Zidentyfikowano także mechanizmy prawne, które aktualnie istnieją i będą w przyszłości z pewnością rozwijane, ale oszacowanie ich wpływu na konkurencyjność jest niemożliwe. Do tych instrumentów należą wszelkiego rodzaju działania rolno-środowiskowo-klimatyczne, czy polityka zazieleniania. Trudno dziś ocenić, na ile egzekwowanie wymogów środowiskowych w działalności rolniczej przyczyni się do wzrostu konkurencyjności rolnictwa. W przyszłości należy także wybrać kilka istotnych wymogów z polityki prośrodowiskowej i je stosować. Aktualna nadmierna ilość kryteriów dostępu do oferowanej pomocy, związanych z wymogami środowiskowymi, zniechęca potencjalnych beneficjentów do korzystania z niej. Niewątpliwie trudniej będzie je spełnić rolnikom, którzy ze środków europejskich korzystają dopiero od kilkunastu lat, niż tym, którzy robią to już lat kilkadziesiąt w tzw. starej Unii. Aktualne instrumenty prawne (poza płatnościami bezpośrednimi) nie różnicują tych kategorii rolników. 
Mając na uwadze powyższe zastrzeżenie trzeba jednakże potwierdzić, że fundusze europejskie przyczyniły się do wzrostu konkurencyjności rolnictwa w Polsce. Jednocześnie podkreślić należy, że w tym piętnastoletnim okresie trudno dostrzec na tym polu istotne działania ustawodawcy krajowego. Dlatego też analizowane instrumenty prawne mają swoje zakotwiczenie w polityce europejskiej. Brakuje dziś wizji konkurencyjności narodowej polskiego rolnictwa w sytuacji drastycznej zmiany WPR, a przede wszystkim zmniejszenia środków dla rolników. Dlatego też de lege ferenda należy rozpocząć prace nad przygotowaniem polskich rolników do zmniejszającego się finansowania, a z czasem przejścia na tzw. instrumenty celowane, nie dostępne powszechnie, tak jak np. płatności bezpośrednie.

2. Konkurencyjność jako cel WPR nadal jest główną determinantą rozwoju rolnictwa. Dokonana analiza ewolucji WPR oraz jej instrumentów prawnych wskazuje, że konkurencyjność stanowiła i stanowi główny warunek rozwoju rolnictwa. Rolnik może otrzymać odpowiednie finansowanie, w zamian za to, że dochodowość jego gospodarstwa wzrośnie. Cel główny, czyli wzrost konkurencyjności, nie zmienił się właściwie od $1957 \mathrm{r}$. Zmieniano natomiast instrumenty prawne, które ten cel miały realizować. Poczynając od silnego protekcjonizmu w postaci przekazywania pieniędzy na funkcjonowanie gospodarstwa oraz interwencję publiczną, po miękkie mechanizmy zachęcające dobrowolnie do innowacyjności, czy inwestycji w gospodarstwo.

W ostatnim okresie finansowania oraz projektowanych założeniach WPR po 2020 r. można zaobserwować powolne odchodzenie od celu wzrostu konkurencyjności na rzecz inwestycji w środowisko i klimat. Istniejące instrumenty prawne, takie jak płatności za zazielenienie czy działania rolno-środowiskowo-klimatyczne mają kompensować rolnikom utracone dochody z uwagi na przedsięwzięcie praktyk korzystnych dla klimatu, czy też gospodarowanie na obszarach cennych przyrodniczo. Zmiana paradygmatu WPR z kierunku czysto ekonomicznego uwzględniającego wzrost dochodowości w kierunku zielonej polityki rolnej ma swoje zalety, ale także nie jest wolna od wad.

Odejście od polityki konkurencyjności w kierunku polityki środowiskowej z pewnością zwiększy ochronę przyrody i zapobiegnie jej degradacji. Cel ten wart jest poparcia. Pozwoli także na zmiany sposobu produkcji z rolnictwa intensywnego w kierunku ekstensywnego, a z czasem pewnie ekologicznego. Poprawi to nie tylko jakość produktów, ale pozytywnie wpłynie na bezpieczeństwo konsumentów i ich zdrowie.

Wadami takiej polityki może okazać się sytuacja globalna rolnictwa. Stosowane praktyki korzystne dla klimatu w UE będą wymuszały większe nakłady na produkcję rolną, mogą spowodować także wzrost cen. Główni konkurenci UE na rynku światowym, czyli Chiny i USA, nie stosując takich praktyk i oferując tańsze produkty mogą zepchnąć rolnictwo europejskie w specjalistyczną 
produkcję ekologiczną, która może nie zapewniać odpowiedniej pozycji konkurencyjnej całemu sektorowi rolnemu. Ponadto, sami rolnicy mogą dojść do wniosku, że oferowana im pomoc, a co za tym idzie określone obowiązki związane z ochroną klimatu mogą okazać się niewystarczające, aby odejść od dotychczasowych sposobów produkcji.

Kształtowane nowe instrumenty WPR związane z tzw. zieloną polityką rolną wymagają także dopracowania legislacyjnego. W dużej części przypadków w Polsce występują kolizje pomiędzy zobowiązaniami wynikającymi z działania rolno-środowiskowo-klimatycznego a planami parków narodowych, krajobrazowych, czy planami zadań ochronnych na obszarach Natura 2000. De lege ferenda wymaga to zmian, które pozwolą w tych działaniach PROW uwzględniać w szerszym stopniu akty prawa powszechnie obowiązującego na terenach cennych przyrodniczo.

Polityka dbałości o środowisko i klimat wpisuje się w koncepcję własności rolniczej sformułowaną przez Andrzeja Stelmachowskiego kilkadziesiąt lat temu. Rolnik będący właścicielem nieruchomości rolnych ma nie tylko prawa i obowiązki cywilistyczne związane ze swoją własnością, ale także obowiązki względem społeczeństwa. W tym nowym ujęciu polityka środowiskowo-klimatyczna byłaby tym obowiązkiem względem społeczeństwa. Rolnik jednak za ponoszone ciężary może oczekiwać określonej pomocy. Pomoc ta powinna kompensować mu ponoszone obowiązki względem społeczeństwa. Trzeba w tym zakresie zadbać o zwiększenie środków finansowych nie tylko na całą WPR, ale przede wszystkim na programy związane z ochroną środowiska i klimatem. W przeciwnym razie nie będą one skuteczne.

Tradycyjnie rozumiana konkurencyjność jako dążenie do zwiększania dochodu odchodzi stopniowo na drugi plan. Uwzględniając już aktualnie obowiązujące instrumenty prawne, związane z zazielenieniem i działaniem rolno-środowiskowo-klimatycznym, będzie bardzo ciężko oszacować, na ile przeznaczone na nie środki wpłynęły na konkurencyjność rolnictwa.

3. Instrumenty prawne, mające poprawić konkurencyjność rolnictwa, naruszają konkurencyjność gospodarki jako całości w systemie wolnorynkowym. Analizowane w rozprawie instrumenty prawne mają charakter pomocy publicznej udzielanej podmiotom lub grupom podmiotów w celu wykonania określonego działania lub też z uwagi na spełnianie określonych $\mathrm{w}$ prawie warunków. W ustroju liberalnym pomoc publiczna co do zasady jest zabroniona (z nielicznymi wyjątkami) na rzecz podmiotów prywatnych. Dlatego też przekazywane rolnikom środki naruszają konkurencyjność całej gospodarki, uprzywilejowując jeden tylko sektor. Oczywiście pozycja rolnictwa jest szczególna, przede wszystkim ze względu na nieprzewidywalność warunków atmosferycznych, czy występowania różnych chorób.

Tak silne wsparcie rolnictwa może okazać się w dłuższej perspektywie dla niego zgubne. Już obecnie ograniczanie finansowania będzie wymuszało 
zmiany w rolnictwie. Powstaje pytanie, które z pewnością będzie aktualne za kilkadziesiąt lat, czy rolnictwo bez wsparcia publicznego będzie w stanie sprostać wyzwaniom rynku? Dotyczy to przede wszystkim małych gospodarstw rolnych. Moim zdaniem będzie to trudne, aby odzwyczaić rolników od możliwości pomocy z zewnątrz. Wymaga to wypracowania już dziś takich mechanizmów prawnych, które w sposób trwały zabezpieczą interesy rolników i pozwolą im w dłuższej perspektywie na samowystarczalność. Przede wszystkim trzeba wypracować instrumenty związane z ubezpieczeniami upraw i działalności rolniczej. Rolnik wtedy mógłby, podobnie jak przedsiębiorcy, korzystać z powszechnie dostępnego w liberalnych gospodarkach systemu. Należy również wypracować instrumenty prawne związane z zabezpieczeniem społecznym rolnika. Te mechanizmy akurat należą do działania państw członkowskich.

Bez kompleksowego podejścia do działalności rolniczej, a pozostawanie tylko na wspieraniu konkretnych inicjatyw, czy rodzajów aktywności rolniczej, może okazać się, że instrumenty prawne poprawiające konkurencyjność są już niewystarczające.

4. Prowadzony instytucjonalny rozdział środków przeznaczonych na rolnictwo wymaga udoskonalenia. Uproszczenie WPR nie może być tylko nośnym sloganem, jak podkreśla cytowany w rozdziale 2 niniejszej pracy agrarysta (zob. P. Litwiniuk, przypis 71), musi stać się rzeczywistością. Problemy skomplikowania niektórych instrumentów zauważa sam prawodawca. Konstruuje w tym zakresie rozbudowane doradztwo rolnicze, którego zadaniem jest pomoc rolnikom w wypełnianiu wniosków, przygotowywaniu dokumentacji. Wiele wymogów wymaga jednak skomplikowanej wykładni prawa, przede wszystkim systemowej i funkcjonalnej. Takie podejście nie sprzyja wzrostowi konkurencyjności.

Przykładem skomplikowanych rozwiązań jest większość działań PROW. Koronnym z nich są działania mające ułatwić pomoc młodym rolnikom. Skorelowanie tych przepisów z rozporządzeniem o płatnościach bezpośrednich, a także z szeregiem aktów prawa krajowego wydaje się zbyt nadmiernym wymaganiem dla rolnika. Dużo kontrowersji budzi sama definicja młodego rolnika, a także aktywnego rolnika. Popierając profesjonalizację zawodu rolnika trzeba się zastanowić, kto nim ma być. Ta jedna definicja wyklucza $\mathrm{z}$ kręgu beneficjentów szereg podmiotów, które pozostają poza systemem jakiegokolwiek wsparcia. To rolnictwo powinno również być konkurencyjne, a nie pozostawione w najlepszym przypadku na przetrwanie, by nie powiedzieć na wegetację.

Zaskakiwanie rolników nowymi wymogami w okresach sześcioletnich nie sprzyja planowaniu długofalowego rozwoju działalności rolniczej. Podkreślane w oficjalnych dokumentach Komisji Europejskiej potrzeby uproszczenia przepisów i ich delegowania w dużej części na państwa członkowskie może 
wywołać jeszcze większy chaos prawny. Pozwoli to na kształtowanie różnych instrumentów w poszczególnych państwach, a to będzie sprzyjało rozwojowi tylko tych, którzy będą ich beneficjentami.

5. Instrumenty prawne oddziałujące na konkurencyjność rolnictwa mają niejednolity charakter przez co czasami się wykluczają. Zanalizowane wybrane instrumenty prawne doprowadziły do szeregu postulatów de lege ferenda. Pierwszym $\mathrm{z}$ nich podnoszonym $\mathrm{w}$ aktach prawnych Komisji Europejskiej jest generalne uproszczenie przepisów. Ilość i stopień skomplikowania zmuszają do weryfikacji istniejących instrumentów prawnych pod kątem ich skuteczności z uwagi na ich skomplikowanie.

Generalnie de lege ferenda należałoby postulować wypracowanie ekonomicznej i prawnej definicji konkurencyjności. Ułatwi to rozumienie celów WPR oraz wprowadzanych dla realizacji tej polityki instrumentów. Uprości także weryfikację efektywności poszczególnych instrumentów prawnych.

$\mathrm{Z}$ uwag generalnych należy również postulować de lege ferenda inne zakotwiczenie PROW w polskim systemie prawa. Rodzi to przede wszystkim problemy wtedy, kiedy dochodzi do niezgodności pomiędzy PROW a postanowieniami ustawy, czy rozporządzeń wykonawczych. Taki stan prawny w istotny sposób wpływa na treść instrumentów prawnych oddziałujących na konkurencyjność rolnictwa. PROW staje się nienazwanym w hierarchii źródeł prawa polskiego samoistnym quasi aktem prawa powszechnie obowiązującego. Taki stan z punktu widzenia konstytucyjnego oraz pewności obrotu jest niedopuszczalny.

Przytaczając tylko niektóre postulaty de lege ferenda szczegółowe w odniesieniu do poszczególnych instrumentów prawnych podano tylko te najistotniejsze. W poddziałaniu „Modernizacja gospodarstw rolnych” niepewność przyznania tej pomocy będzie zniechęcać rolników do inwestowania własnych pieniędzy. Będą oni woleli nadal pracować na starym sprzęcie, w niezmodernizowanych budynkach, ale z pewnością oczekiwanego zysku. Ryzyko w tym zakresie może się okazać dla nich zbyt duże. Dlatego też należy postulować de lege ferenda, aby ten instrument prawny zmodyfikować w kierunku dotacji udzielanej przed zakupem środków lub promesy tej dotacji. Można również zintensyfikować działania na udzielanie niskooprocentowanych kredytów dla rolników chcących skorzystać z tego instrumentu.

W poddziałaniu „Premia dla młodych rolników” ryzyko związane z utratą środków może okazać się zbyt duże. Jest to jeden z mankamentów tego instrumentu. De lege ferenda należałoby postulować zobowiązanie młodego rolnika do rozpoczęcia działalności już po otrzymaniu pomocy, albo wypłacenie jej w dniu zarejestrowania działalności. De lege ferenda należy już dziś sformułować postulat odpowiadający generalnemu uproszczeniu WPR. Analizowane poddziałanie jest doskonałym przykładałem, jak dobrze zaprojektowany instrument ekonomiczny może zostać zaprzepaszczony poprzez stosowanie 
niewspółmiernych do wysokości udzielanej pomocy wymogów. W przypadku ich niespełnienia niebezpieczeństwo płacenia kar, a co za tym idzie bankructwa młodego rolnika skutecznie odstrasza od ubiegania się o tę pomoc. Nadmierność sankcji przy niespełnieniu chociażby jednego z wymogów może okazać się katastrofalna dla beneficjenta. Postulat ten był już zresztą podnoszony przez uznanych agrarystów w polskim prawie rolnym (por. rozdział 4, przypis 46). Oznacza konieczność zwrotu całej otrzymanej dotacji. W większości przypadków młodych rolników nie będzie na to stać. Podobnie zresztą jak nie będą mieli możliwości finansowych skarżenia ARMiR przed sądem. De lege ferenda zarówno w prawie krajowym, jak i europejskim trzeba postulować wyraźnie rozgraniczenie dotkliwości kar za niewykonanie poszczególnych wymogów. Można je stosować, chociażby w ujęciu proporcjonalnym do niewłaściwie wydatkowanych środków.

W poddziałaniu „Płatności na rzecz rolników kwalifikujących się do systemu małych gospodarstw, którzy trwale przekazali swoje gospodarstwo rolne innemu rolnikowi" można by ten instrument połączyć de lege ferenda z regulacjami dotyczącymi ubezpieczenia społecznego rolników, cieszyłby się on większym zainteresowaniem rolników, którzy ze względu na wiek nie mogą już prowadzić swojej działalności. Zbliżyłby się wtedy w konstrukcji prawnej do rent strukturalnych. Byłby oczywiście znacznie mniej atrakcyjny poprzez jednorazową dotację. W dotychczasowym działaniu renty strukturalne w połączenie z ustawą o ubezpieczeniu społecznym rolników było dość jednoznaczne. Trzeba tylko pamiętać, aby odpowiednio określić dane lata przechodzenia na emeryturę, tudzież osiągania innych świadczeń. W przeciwnym razie może dochodzić do niezgodności, tak jak przy rentach strukturalnych w wieku emerytalnym 67 lat. Pobieranie renty strukturalnej kończy się z chwilą osiągnięcia przez beneficjenta 65 lat. W sytuacji, gdy obowiązywał wiek emerytalny 67 lat taki beneficjent pozostawał bez środków do życia przez kolejne dwa lata. Nowelizując kolejne przepisy trzeba pamiętać, że nie są one obecnie odizolowane od pozostałych.

W działaniu rolno-środowiskowo-klimatycznym de lege ferenda należałoby postulować ograniczenie możliwych kolizji i włączenie do planów rolno-środowiskowo-klimatycznych postanowień aktów prawnych obwiązujących na danym obszarze, a wynikających ze specjalnego statusu danego terenu.

W rolnictwie ekologicznym de lege ferenda należy postulować pilne uregulowanie statusu upraw ekologicznych oraz nieruchomości sąsiedzkich. Bez tego typu unormowań instrument ten nie będzie w pełni spełniał swojego zadania, a na rynek mogą trafiać produkty, które nie będą ekologiczne.

$\mathrm{W}$ odniesieniu do jednolitego rynku rolnego nadal nie jest jasny status relacji rozporządzenia 1308/2013 i polskiej ustawy o organizacji niektórych rynków rolnych. Kolizje występujące pomiędzy tymi aktami rozstrzygane są co prawda na korzyść rozporządzenia, ale de lege ferenda ustawa ta wymaga nowelizacji. 
W rozprawie zaprezentowano również szereg innych propozycji, które mają za zadanie poprawić funkcjonowanie istniejących instrumentów prawnych. Należy podjąć także już dziś prace nad analizą przygotowywanych rozwiązań prawnych WPR po 2020 r. Jest to tym bardziej pilne zadanie, że duża część dotychczasowych zadań z poziomu europejskiego zostanie przeniesiona na poziom legislacji krajowej.

6. Formalnoprawne procedury rozdziału środków pochodzących z funduszy europejskich są poprawnie przygotowane i co do zasady właściwie stosowane. Nie wyklucza to jednakże pewnych komplikacji na poziomie składania wniosków i rozliczeń. Zasygnalizowana problematyka nadmiernych kar w poddziałaniu „Premie dla młodych rolników” jest związana z niewłaściwym sposobem dokonywania kontroli oraz interpretacji przepisów. Ponadto, występują techniczne problemy ze składaniem wniosków w wyniku awarii lub opóźnień w działaniu systemu informatycznego. Przy zaplanowanych inwestycjach i biznesplanach opóźnienia rzędu kilku miesięcy poważnie wpływają na skuteczność wykorzystywanych środków i ich oddziaływanie na konkurencyjność rolnictwa.

Reasumując, z przeprowadzonych badań można wywieść kilka wniosków natury ogólnej. Związane one są z istniejącymi instrumentami prawnymi oraz ewentualnymi pracami legislacyjnymi nad przyszłą polityką rolną w UE.

Dokonane analizy wskazały, że pomoc publiczna kierowana do rolników burzy zasady wolnego rynku. Efekty konkurencyjności rolnictwa są nierzetelne z uwagi na brak możliwości wyodrębnienia efektywności środków publicznych i prywatnych dochodów rolników przeznaczanych na rolnictwo. Wśród mechanizmów prawnych realizujących cel WPR, jakim jest wzrost konkurencyjności, a także cel ekonomiczny, jakim jest uzyskanie przewagi konkurencyjnej, przeprowadzone badania pozwalają na różne kwalifikacje analizowanych instrumentów prawnych.

Można pośród tych mechanizmów wyróżnić te, które mają charakter ściśle protekcjonistyczny. Są one wsparciem dla rolników w celu preferencji europejskiej i zachowania przewagi konkurencyjnej przez bezpośrednią pomoc publiczną. W większości przypadków tych instrumentów nie jest konieczne wykazanie konkretnego efektu, który został osiągnięty dzięki udzielonej pomocy. Do takich instrumentów można zaliczyć dopłaty bezpośrednie, certyfikaty eksportowe, pozwolenia importowe, czy refundacje wywozowe. Przykładem takich instrumentów są także ograniczenia w produkcji roślin i żywności GMO. W UE w tym zakresie dopuszczono tylko kilka produktów. Protekcjonizm w tym przypadku opiera się na zachowaniu bezpieczeństwa konsumentów. Nie jest do końca jasne, czy prowadzi do pozytywnych skutków, z uwagi na brak długoterminowych badań naukowych, które w ostateczny sposób rozstrzygnęłyby o konsekwencjach stosowania GMO w rolnictwie.

Drugim rodzajem mechanizmów prawnych realizujących cel konkurencyjności są instrumenty interwencji publicznej. Stosowane są one zazwyczaj w sytuacjach 
kryzysu na rynku rolnym. Oznaczają publicznoprawną ingerencję w wolny rynek, ale na wcześniej znanych i określonych zasadach. Przykładem takich mechanizmów jest interwencja publiczna - zwana też skupem interwencyjnym. Dokonywana do ściśle określonych produktów, według zasad opisanych w rozporządzeniu europejskim. Mechanizmowi interwencji towarzyszy system cen rolnych, zarówno tych stosowanych na rynku wewnętrznym, jak i tych w handlu z państwami trzecimi. Ponadto, można w tym zakresie wyróżnić mechanizmy nadzwyczajnej pomocy w sytuacjach kryzysowych na rynku rolnym. Przykładem takich kryzysów są zachwiania rynku spowodowane chorobami odzwierzęcymi (przykład ASF), bądź klęskami żywiołowymi. Można do tych instrumentów interwencyjnych zaliczyć także nomenklaturę scaloną, czy system nazw chronionych produktów rolnych. Historycznie należałoby również uwzględnić w tym miejscu system kwotowania produkcji rolnej.

Do trzeciej grupy instrumentów prawnych można zaliczyć mechanizmy wspomagania na zasadach pomocy publicznej przyznawanej w drodze konkursu. Tutaj przykładem są wszystkie instrumenty określone w PROW. Należą do nich zarówno instrumenty inwestycyjne, społeczne, jak i prośrodowiskowe. Są to mechanizmy celowane w konkretny rodzaj pomocy dla rolników. W większości przypadków da się określić efekt udzielonej pomocy i ocenić zasadność wydatkowanych środków. W przyszłości należałoby rekomendować wprowadzenie tego rodzaju instrumentów jako podstawy funkcjonowania WPR.

Do czwartej kategorii mechanizmów realizujących politykę konkurencyjności wyrażoną w WPR można zaliczyć wszystkie inne instrumenty prawne. Ich konstrukcja legislacyjna, znaczenie dla rolnictwa oraz sposób rozliczania są zróżnicowane. Tytułem przykładu można tutaj tylko podać płatności za zazielenianie. Należą one do mechanizmów o charakterze protekcjonistycznym, ale z uwagi na ich społeczno-środowiskowy cel powinny mieć długoterminowe działanie w przyszłości. Innym takim mechanizmem jest płatność do obszarów o szczególnych warunkach gospodarowania $(\mathrm{ONW})$. Pozwala ona na prowadzenie ograniczonej, ze względu na warunki przyrodnicze, działalności rolniczej. Kompensacja finansowa spełnia w tym zakresie nie tylko rolę inwestycji, czy wsparcia społecznego, ale przede wszystkim pozwala w miarę możliwości na prowadzenie działalności rolniczej na tych terenach. Ten rodzaj mechanizmów prawnych jest również różnie umieszczony w strukturze hierarchii źródeł prawa europejskiego i krajowego.

Przeprowadzone badania wskazały na istnienie systemu instrumentów prawnych WPR, mających wpływ na konkurencyjność rolnictwa. Dysfunkcyjność któregoś z tych mechanizmów pociąga za sobą nieefektywność lub mniejszą skuteczność innego mechanizmu. Przeprowadzone badania oraz wskazane powyżej wyniki mają być tylko asumptem do dalszej dyskusji, w jaki sposób należy formułować instrumenty prawne, które mają pomóc rolnikom lepiej prowadzić swoją działalność, a jednocześnie pozytywnie wpływać na konkurencyjność rolnictwa. 



\section{Bibliografia}

\section{Akty prawne}

Dyrektywa 2000/60/WE Parlamentu Europejskiego i Rady z dnia 23 października 2000 r. ustanawiająca ramy wspólnotowego działania w dziedzinie polityki wodnej (Dz. Urz. UE L Nr 327, s. 1).

Dyrektywa 2006/118/WE Parlamentu Europejskiego i Rady z dnia 12 grudnia 2006 r. w sprawie ochrony wód podziemnych przed zanieczyszczeniem i pogorszeniem ich stanu (Dz. Urz. UE L Nr 372, s. 19 z późn. zm.).

Dyrektywa 2006/7/WE Parlamentu Europejskiego i Rady z dnia 15 lutego 2006 r. dotycząca zarządzania jakością wody w kąpieliskach i uchylająca dyrektywę 76/160/EWG (Dz. Urz. UE L Nr 64, s. 37 z późn. zm.).

Dyrektywa 79/409/EWG Rady z dnia 2 kwietnia 1979 r. o ochronie dziko żyjących ptaków (Dz. Urz. UE L z 1979 r. Nr 103, s. 1 z późn. zm.) która zastąpiona została nową dyrektywą 2009/147/WE Parlamentu Europejskiego i Rady z dnia 30 listopada 2009 r. w sprawie ochrony dzikiego ptactwa (Dz. U UE L z 2010 r. Nr 20, s. 7 z późn. zm.).

Dyrektywa 92/43/EWG Rady z dnia 21 maja 1992 r. w sprawie ochrony siedlisk przyrodniczych oraz dzikiej fauny i flory (Dz. Urz. UE L z 1992 r. Nr 206, s. 7 z późn. zm.).

Dyrektywa Parlamentu Europejskiego i Rady 2008/105/WE z dnia 16 grudnia 2008 r. w sprawie środowiskowych norm jakości w dziedzinie polityki wodnej, zmieniająca i w następstwie uchylająca dyrektywy Rady 82/176/EWG, 83/513/EWG, 84/156/EWG, 84/491/EWG i 86/280/EWG oraz zmieniająca dyrektywę 2000/60/WE Parlamentu Europejskiego i Rady (Dz. Urz. UE L Nr 348, s. 84 z późn. zm.).

Dyrektywa Rady 91/271/EWG z dnia 21 maja 1991 r. dotycząca oczyszczania ścieków komunalnych (Dz. Urz. WE L Nr 135, s. 40 z późn. zm.).

Dyrektywa Rady 91/676/EWG z dnia 12 grudnia 1991 r. dotycząca ochrony wód przed zanieczyszczeniami powodowanymi przez azotany pochodzenia rolniczego (Dz. Urz. WE L Nr 375, s. 1 z późn. zm.).

Komunikat Komisji z dnia 3 marca 2010 r. Europa 2020. Strategia na rzecz inteligentnego i zrównoważonego rozwoju sprzyjającego właczeniu społecznemu, KOM (2010) 2020.

Komunikat Ministra Rolnictwa i Rozwoju Wsi z dnia 17 czerwca 2015 r. o zatwierdzeniu przez Komisję Europejską Programu Rozwoju Obszarów Wiejskich na lata 2014-2020 (M.P. poz. 541).

Konstytucja Rzeczypospolitej Polskiej z dnia 2 kwietnia 1997 r. (Dz. U. poz. 483 z późn. zm.).

Obwieszczenie Ministra Rolnictwa i Rozwoju Wsi z dnia 12 października 2007 r. w sprawie Programu Rozwoju Obszarów Wiejskich na lata 2007-2013 (M.P. poz. 1035 z późn. zm.).

Opinia Europejskiego Komitetu Ekonomiczno-Społecznego „W sprawie przyszłości młodych rolników w Europie" (Dz. U. UE C 2011 Nr 376, s. 19).

Resolution on the New Guidelines for the Common Agricultural Policy z 25 maja 1971 r. (Dz. Urz. C 52 z 27.05.1971, s. 1).

Rozporządzenie delegowane Komisji (UE) nr 807/2014 z dnia 11 marca 2014 r. uzupełniające rozporządzenie Parlamentu Europejskiego i Rady (UE) nr 1305/2013 w sprawie wsparcia rozwoju 
obszarów wiejskich przez Europejski Fundusz Rolny na rzecz Rozwoju Obszarów Wiejskich (EFRROW) i wprowadzające przepisy przejściowe (Dz. Urz. UE L Nr 227, s. 1).

Rozporządzenie Ministra Rolnictwa i Rozwoju Wsi z dnia 1 marca 2019 r. w sprawie szczegółowych warunków i trybu przyznawania oraz wypłaty pomocy finansowej na operacje typu „Inwestycje odtwarzające potencjał produkcji rolnej” w ramach poddziałania „Wsparcie inwestycji w odtwarzanie gruntów rolnych i przywracanie potencjału produkcji rolnej zniszczonego w wyniku klęsk żywiołowych, niekorzystnych zjawisk klimatycznych i katastrof" objętego Programem Rozwoju Obszarów Wiejskich na lata 2014-2020 (Dz. U. poz. 431).

Rozporządzenie Ministra Rolnictwa i Rozwoju Wsi z dnia 13 lipca 2015 r. w sprawie szczegółowych warunków i trybu przyznawania, wypłaty oraz zwrotu pomocy finansowej na operacje typu „Premie dla młodych rolników” w ramach poddziałania „Pomoc w rozpoczęciu działalności gospodarczej na rzecz młodych rolników” objętego Programem Rozwoju Obszarów Wiejskich na lata 2014-2020 (Dz. U. z 2018 r. poz. 759 z późn. zm.).

Rozporządzenie Ministra Rolnictwa i Rozwoju Wsi z dnia 13 marca 2015 r. w sprawie szczegółowych warunków i trybu przyznawania pomocy finansowej w ramach działania „Rolnictwo ekologiczne" objętego Programem Rozwoju Obszarów Wiejskich na lata 2014-2020 (Dz. U. z 2018 r. poz. 1784).

Rozporządzenie Ministra Rolnictwa i Rozwoju Wsi z dnia 13 sierpnia 2015 r. w sprawie danych niezbędnych do właściwego monitorowania realizacji i ewaluacji Programu Rozwoju Obszarów Wiejskich na lata 2014-2020 (Dz. U. poz. 1397).

Rozporządzenie Ministra Rolnictwa i Rozwoju Wsi z dnia 18 kwietnia 2016 r. w sprawie szczegółowych warunków o trybu przyznawania, wypłaty oraz zwrotu pomocy finansowej w ramach poddziałania „Płatności na rzecz rolników kwalifikujących się do systemu małych gospodarstw, którzy trwale przekazali swoje gospodarstwo rolne innemu rolnikowi” objętego Programem Rozwoju Obszarów Wiejskich na lata 2014-2020 (Dz. U. poz. 598 z późn. zm.).

Rozporządzenie Ministra Rolnictwa i Rozwoju Wsi z dnia 18 marca 2015 r. w sprawie szczegółowych warunków i trybu przyznawania pomocy finansowej w ramach działania „Działanie rolno-środowiskowo-klimatyczne" objętego Programem Rozwoju Obszarów Wiejskich 2014-2020 (Dz. U. poz. 415 z późn. zm.).

Rozporządzenie Ministra Rolnictwa i Rozwoju Wsi z dnia 2 sierpnia 2016 r. w sprawie szczegółowych warunków i trybu przyznawania, wypłaty oraz zwrotu pomocy finansowej w ramach działania „Tworzenie grup producentów rolnych i organizacji producentów objętego Programem Rozwoju Obszarów Wiejskich na lata 2014-2020 (Dz. U. poz. 1284 z późn. zm.).

Rozporządzenie Ministra Rolnictwa i Rozwoju Wsi z dnia 21 sierpnia 2015 r. w sprawie warunków i trybu przeprowadzania czynności kontrolnych w ramach Programu Rozwoju Obszarów Wiejskich na lata 2014-2020 (Dz. U. poz. 1344).

Rozporządzenie Ministra Rolnictwa i Rozwoju Wsi z dnia 21 sierpnia 2015 r. w sprawie szczegółowych warunków i trybu przyznawania oraz wypłaty pomocy finansowej na operacje typu „Modernizacja gospodarstw rolnych” objętego Programem Rozwoju Obszarów Wiejskich na lata 2014-2020 (Dz. U. poz. 1371 z późn. zm.).

Rozporządzenie Ministra Rolnictwa i Rozwoju Wsi z dnia 22 marca 2017 r. w sprawie szczegółowych warunków przyznawania pomocy finansowej w ramach poddziałania „Wsparcie korzystania z usług doradczych" objętego Programem Rozwoju Obszarów Wiejskich na lata 2014-2020 oraz warunków i trybu jej wypłaty (Dz. U. poz. 692 z późn. zm.); rozporządzenie Ministra Rolnictwa i Rozwoju Wsi z dnia 21 marca 2017 r. w ramach poddziałania „Wsparcie dla szko- 
lenia doradców" objętego Programem Rozwoju Obszarów Wiejskich na lata 2014-2020 oraz warunków i trybu jej wypłaty (Dz. U. poz. 642 z późn. zm.).

Rozporządzenie Ministra Rolnictwa i Rozwoju Wsi z dnia 23 października 2015 r. w sprawie szczegółowych warunków i trybu przyznawania oraz wypłaty pomocy finansowej na operacje typu „Rozwój przedsiębiorczości - rozwój usług rolniczych” w ramach poddziałania „Wsparcie inwestycji w tworzenie i rozwój działalności pozarolniczej” objętego Programem Rozwoju Obszarów Wiejskich na lata 2014-2020 (Dz. U. poz. 1843).

Rozporządzenie Ministra Rolnictwa i Rozwoju Wsi z dnia 24 marca 2015 r. w sprawie warunków, jakie powinny spełniać jednostki organizacyjne, którym agencja płatnicza może powierzyć wykonywanie czynności kontrolnych w ramach Programu Rozwoju Obszarów Wiejskich na lata 2014-2020 (Dz. U. poz. 473).

Rozporządzenie Ministra Rolnictwa i Rozwoju Wsi z dnia 3 listopada 2015 r. w sprawie zaliczek w ramach Programu Rozwoju Obszarów Wiejskich na lata 2014-2020 (Dz. U. poz. 1857).

Rozporządzenie Ministra Rolnictwa i Rozwoju Wsi z dnia 31 marca 2014 roku w sprawie środków podejmowanych w związku z wystąpieniem u dzików afrykańskiego pomoru świń (Dz. U. poz. 420).

Rozporządzenie Ministra Rolnictwa i Rozwoju Wsi z dnia 4 września 2015 r. w sprawie szczegółowych warunków i trybu przyznawania oraz wypłaty pomocy finansowej na operacje typu „Budowa lub modernizacja dróg lokalnych” w ramach poddziałania „Wsparcie inwestycji związanych z tworzeniem, ulepszaniem lub rozbudową wszystkich rodzajów małej infrastruktury, w tym inwestycji w energię odnawialną i w oszczędzanie energii” objętego Programem Rozwoju Obszarów Wiejskich na lata 2014-2020 (Dz. U. poz. 1414 z późn. zm.).

Rozporządzenie Ministra Rolnictwa i Rozwoju Wsi z dnia 6 sierpnia 2015 r. w sprawie szczegółowych warunków i trybu przyznawania wypłaty oraz zwrotu pomocy finansowej w ramach poddziałania „Wsparcie na przystępowanie do systemów jakości” (Dz. U. poz. 1195 z późn. zm.).

Rozporządzenie Ministra Rolnictwa i Rozwoju Wsi z dnia 19 czerwca 2007 r. w sprawie szczegółowych warunków i trybu przyznawania pomocy finansowej w ramach działania „Renty strukturalne" objętego Programem Rozwoju Obszarów Wiejskich na lata 2007-2013 (Dz. U. poz. 750 z późn. zm.).

Rozporządzenie Parlamentu Europejskiego i Rady(UE)nr 1303/2013 zdnia 17 grudnia 2013 r. ustanawiające wspólne przepisy dotyczące Europejskiego Funduszu Rozwoju Regionalnego, Europejskiego Funduszu Społecznego, Funduszu Spójności, Europejskiego Funduszu Rolnego na rzecz Rozwoju Obszarów Wiejskich oraz Europejskiego Funduszu Morskiego i Rybackiego oraz ustanawiające przepisy ogólne dotyczące Europejskiego Funduszu Rozwoju Regionalnego, Europejskiego Funduszu Społecznego, Funduszu Spójności i Europejskiego Funduszu Morskiego i Rybackiego oraz uchylające rozporządzenie Rady (WE) nr 1083/2006 (Dz. Urz. UE L Nr 342, s. 320 z późn. zm.).

Rozporządzenie Parlamentu Europejskiego i Rady (UE) nr 1305/2013 z dnia 17 grudnia 2013 r. w sprawie wsparcia rozwoju obszarów wiejskich przez Europejski Fundusz Rolny na rzecz Rozwoju Obszarów Wiejskich (EFRROW) i uchylające rozporządzenie Rady (WE) nr 1698/2005 (Dz. U. UE L Nr 347, s. 487 z późn. zm.).

Rozporządzenie Parlamentu Europejskiego i Rady (UE) nr 1306/2013 z dnia 17 grudnia 2013 r. W sprawie finansowania wspólnej polityki rolnej, zarządzania nią i monitorowania jej oraz uchylające rozporządzenia Rady (EWG) nr 352/78, (WE) nr 165/94, (WE) nr 2799/98, (WE) nr 814/2000, (WE) nr 1290/2005 i (WE) nr 485/2008 (Dz. Urz. UE L Nr 347, s. 549 z późn. zm.). 
Rozporządzenie Parlamentu Europejskiego i Rady (UE) nr 1307/2013 z dnia 17 grudnia 2013 r. ustanawiające przepisy dotyczące płatności bezpośrednich dla rolników na podstawie systemów wsparcia w ramach wspólnej polityki rolnej oraz uchylające rozporządzenie Rady (WE) nr 637/2008 i rozporządzenie Rady (WE) nr 73/2009 (Dz. Urz. UE L Nr 347, s. 608 z późn. zm.).

Rozporządzenie Parlamentu Europejskiego i Rady (UE) nr 1308/2013 z dnia 17 grudnia 2013 r. ustanawiające wspólną organizację rynków produktów rolnych oraz uchylające rozporządzenia Rady (EWG) nr 922/72, (EWG) nr 234/79, (WE) nr 1037/2001 i (WE) nr 1234/2007 (Dz. Urz. UE L z 2013 r. Nr 347, s. 671 ze zm.); wcześniej Rozporządzenie Rady (WE) nr 1234/2007 z 22 października 2007 r. ustanawiające wspólną organizację rynków rolnych oraz przepisy szczegółowe dotyczące niektórych produktów rolnych (,rozporządzenie o jednolitej wspólnej organizacji rynku") (Dz. Urz. UE L 299 z 16 listopada 2007 r., s. 1-149 ze zm.).

Rozporządzenie Rady (WE) nr 1234/2007 z dnia 22 października 2007 r. ustanawiające wspólną organizację rynków rolnych oraz przepisy szczegółowe dotyczące niektórych produktów rolnych (rozporządzenie o jednolitej wspólnej organizacji rynku) (Dz. Urz. UE L Nr 299, s. 1 z późn. zm.).

Rozporządzenie Rady (WE) nr 834/2007 z dnia 28 czerwca 2007 r. w sprawie produkcji ekologicznej i znakowania produktów ekologicznych i uchylające rozporządzenie (EWG) nr 2092/91 (Dz. Urz. UE L Nr 189, s. 1 z późn. zm.).

Rozporządzenie Rady Ministrów z dnia 14 września 2015 r. w sprawie pożyczek z budżetu państwa na wyprzedzające finansowanie w ramach Programu Rozwoju Obszarów Wiejskich na lata 2014-2020 (Dz. U. poz. 1558).

Rozporządzenie wykonawcze Komisji (UE) nr 324/2014 z dnia 28 marca 2014 r. przyjmujące nadzwyczajne środki wspierania rynku wieprzowiny w Polsce (Dz. Urz. UE L z 2014 r. Nr 95, s. 24).

Rozporządzenie wykonawcze Komisji (UE) 2016/760 z dnia 13 maja 2016 r. w sprawie nadzwyczajnych środków wsparcia dla sektorów jaj i mięsa drobiowego we Włoszech (Dz. Urz. UE L z 2016 r. Nr 126, s. 63).

Rozporządzenie wykonawcze Komisji (UE) nr 428/2014 z dnia 25 kwietnia 2014 r. przyjmujące nadzwyczajne środki wspierania rynku wieprzowiny na Litwie i zmieniające rozporządzenie wykonawcze (UE) nr 324/2014 przyjmujące nadzwyczajne środki wspierania rynku wieprzowiny w Polsce (Dz. Urz. UE L z 2014 r. Nr 125, s. 64).

Rozporządzenie wykonawcze Komisji (UE) nr 808/2014 z dnia 17 lipca 2014 r. ustanawiające zasady stosowania rozporządzenia Parlamentu Europejskiego i Rady (UE) nr 1305/2013 w sprawie wsparcia rozwoju obszarów wiejskich przez Europejski Fundusz Rolny na rzecz Rozwoju Obszarów Wiejskich (EFRROW) (Dz. Urz. UE L Nr 227, s. 18).

Traktat o funkcjonowaniu Unii Europejskiej (Dz. U. z 2004 r. poz. 864/2 z późn. zm.).

Uchwała nr 163 Rady Ministrów z dnia 25 kwietnia 2012 r. w sprawie przyjęcia „Strategii zrównoważonego rozwoju wsi, rolnictwa i rybactwa” na lata 2012-2020 (M.P. poz. 839).

Uchwała nr 8 Rady Ministrów w sprawie przyjęcia Strategii na rzecz Odpowiedzialnego Rozwoju do roku 2020 (z perspektywą do 2030 r.) (M.P. 2017 poz. 260).

Ustawa z dnia 11 kwietnia 2003 r. o kształtowaniu ustroju rolnego (Dz. U. z 2017 r. poz. 2196 z późn. zm.).

Ustawa z dnia 15 września 2000 r. o grupach producentów rolnych i ich związkach oraz o zmianie innych ustaw (Dz. U. z 2018 r. poz. 1026).

Ustawa z dnia 16 kwietnia 2004 r. o ochronie przyrody (Dz. U. z 2015 r. poz. 1651 z późn. zm.). 
Ustawa z dnia 20 kwietnia 2004 r. o organizacji rynku mleka i przetworów mlecznych (Dz. U. z 2018 r. poz. 724 z późn. zm.).

Ustawa z dnia 20 lipca 2017 r. Prawo wodne (Dz. U. z 2018 r. poz. 2268 z późn. zm.).

Ustawa z dnia 20 lutego 2015 r. o wspieraniu rozwoju obszarów wiejskich z udziałem środków Europejskiego Funduszu Rolnego na rzecz Rozwoju Obszarów Wiejskich w ramach Programu Rozwoju Obszarów Wiejskich na lata 2014-2020 (Dz. U. z 2018 r. poz. 627 z późn. zm.).

Ustawa z dnia 22 października 2004 r. o jednostkach doradztwa rolniczego (Dz. U. z 2013 r. poz. 474).

Ustawa z dnia 25 czerwca 2009 r. o rolnictwie ekologicznym (Dz. U. z 2017 r. poz. 1054 z późn. zm.).

Ustawa z dnia 27 maja 2015 r. o finansowaniu wspólnej polityki rolnej (Dz. U. z 2018 r. poz. 719 z późn. zm.).

Ustawa z dnia 20 lutego 2015 r. o rozwoju lokalnym z udziałem lokalnej społeczności (Dz. U. z 2018 r. poz. 140 z późn. zm.).

Ustawa z dnia 29 stycznia 2004 r. Prawo zamówień publicznych (Dz. U. z 2017 r. poz. 1579 z późn. zm.).

Ustawa z dnia 5 lutego 2015 r. o płatnościach w ramach systemów wsparcia bezpośredniego (Dz. U. z 2018 poz. 1312 z późn. zm.).

\section{Orzeczenia}

Wyrok Naczelnego Sądu Administracyjnego z dnia 3 marca 2011 r., II OSK 2251/10.

Wyrok Trybunału Konstytucyjnego K 13/98.

Wyrok Trybunału Konstytucyjnego P 2/98.

Wyrok Trybunału Konstytucyjnego SK 9/.

Wyrok Trybunału w sprawie C-101/05, Skatteverket.

Wyrok Trybunału w sprawie C-169/07, Hartlauer.

Wyrok Trybunału w sprawie C-17/03, VEMW.

Wyrok Trybunału w sprawie C-182/03 oraz C-217/03, Forum 187.

Wyrok Trybunału w sprawie C-182/83, Fearon.

Wyrok Trybunału w sprawie C-243/01, Gambelli.

Wyrok Trybunału w sprawie C-302/97, Konle; sprawy połączone C-515/99-C-524/99 oraz C-526/99-C-540/99, Reisch.

Wyrok Trybunału w sprawie C-333/14, Scotch Whiskey.

Wyrok Trybunału w sprawie C-370/05, Festersen.

Wyrok Trybunału w sprawie C-423/98, Albore.

Wyrok Trybunału w sprawie C-446/04, Test Claimants in the FII Group Litigation.

Wyrok Trybunału w sprawie C-452/01, Ospelt.

Wyrok Trybunału z dnia 15 listopada 1979 r. w sprawie 36/79, Denkavit Futtermittel GmbH v. Finanzamt Warendorf, ECR 1979, s. 03439.

Wyrok Trybunału z dnia 16 grudnia $1975 \mathrm{r}$. w połączonych sprawach $\mathrm{nr}$ 40-48, 50, 54-56, 111, 113 i 114/73, Coöperatieve Vereniging ,Suiker Unie” UA and others v. Commission, ECR 1975, s. 01663.

Wyrok TS UE z dnia 4 czerwca 2009 r. w sprawie C-241/07.

Wyrok TS z 10 października 1973 r. w sprawie 34/73 Fratelli Variola S.p.A przeciwko Admministrazione italiana delle Finanze, Zb. Orz. 1973, s. 981.

Wyrok TS z 10 stycznia 1985 r. w sprawie 229/83 Association des Centres distributeurs Éduard Leclers i inni przeciwko SARL „Au blé” i inni, Zb. Orz. 1985, s. 1. 
Wyrok TS z dnia 11 czerwca 1985 r. w sprawie 288/83 Komisja Wspólnot Europejskich przeciwko Irlandii, Zb. Orz. 1985, s. 1761.

Wyrok TS z dnia 20 kwietnia 1978 r. w połączonych sprawach 80 i 81/77 Société Les Commissionnaires Réunis SARL przeciwko Receveur des douanes; SARL Les fils de Henri Ramel przeciwko Receveur des douanes, Zb. Orz. 1978, s. 927.

Wyrok TS z dnia 5 marca 1996 r. w połączonych sprawach C-46/93 i C-48/93 Brasserie du Pêceur SA przeciwko Bundesrepublik Deutschland i The Queen przeciwko Secretary of State for Transport, ex parte: Factorame Ltd i innym, Zb. Orz. 1996, s. I-1029.

Wyrok TS z dnia 7 marca 1972 r. sprawie 84/71 SpA Marimex przeciwko Ministero delle Finanze, Zb. Orz. 1972, s. 89.

Wyrok Wojewódzkiego Sądu Administracyjnego w Szczecinie z 16 kwietnia 2016 r., II SA/Sz 905/14. Wyrok Wojewódzkiego Sądu Administracyjnego w Szczecinie z dnia 5 czerwca 2013 r. II SA/Sz 245/13. Wyrok z dnia 13 października 1982 r. w połączonych sprawach 213-215/81, Norddeutsches Viehund Fleischkontor Herbert Will, Trawako, Transit-Warenhandels-Kontor GmbH \& Co., i Gedelfi, Großeinkauf GmbH \& Co., v. Bundesanstalt für landwirtschaftliche Marktordnung, ECR 1982, s. 03583.

\section{Literatura}

Adamkiewicz H., Uwarunkowania konkurencyjności przedsiębiorstw w gospodarce rynkowej, Gdynia 1999.

Adamkiewicz H.G., Wewnętrzne i zewnętrzne uwarunkowania konkurencyjności przedsiębiorstw, [w:] Konkurencyjność gospodarki Polski w warunkach integracji z Unia Europejska i globalizacji, J. Staszewski (red.), Warszawa 2004.

Adamowicz M., Szepeluk A., Wsparcie młodych rolników jako element polityki rolnej Unii Europejskiej, „Zagadnienia Ekonomiki Rolnej”, 2016, nr 3 (348).

Adinolfi F., Altomare U., Boanini L., Domenico M. Di, Capitanio F., Casadio G., Guido M., Trezza F., Sviluppo rurale 2014-2020: Studio per l'attuazione in Italia dello strumento di stabilizzazione del reddito delle imprese agricole, Roma 2015.

Adornato F., Ochrona rodzinnego gospodarstwa rolnego we Włoszech, [w:] Prawne mechanizmy wspierania i ochrony rolnictwa rodzinnego w Polsce i innych państwach Unii Europejskiej, P. Litwiniuk (red.), Warszawa 2015.

Albisini F., Europejskie kodeksy rolnictwa i ponowne odkrycie rolnictwa jako działalności produkcyjnej, [w:] Kwestia agrarna. Zagadnienia prawne i ekonomiczne, P. Litwiniuk (red.), Warszawa 2016.

Ambroziak Ł., Potencjalny wptyw Umowy o partnerstwie gospodarczym UE - Japonia na polski handel rolno-spożywczy z Japonia, ,Studia i Prace WNEiZ US”, 2018, nr 53 (2).

Anderson G., Śleszyński J., Ekonomiczna wycena środowiska przyrodniczego, [w:] Wartościowanie dóbr i zasobów środowiska, J. Śleszyński (red.), Białystok 1996.

Baer-Nawrocka A., Kiryluk-Dryjska E., Wptyw likwidacji kwot mlecznych na sytuację produkcyjna i ekonomiczna producentów mleka w Unii Europejskiej (wyniki symulacji modelowych), „Wieś i Rolnictwo", 2010, nr 3.

Baer-Nawrocka A., Suchoń A., Ochrona produktów regionalnych i tradycyjnych $w$ Unii Europejskiej. Wybrane zagadnienia ekonomiczne i prawne, „Wieś i Rolnictwo”, 2014, nr 4.

Balkhausen O., Banse M., Grethe H., Modelling CAP decoupling in the EU: a comparison of selected simulation models and results, ,Journal of Agricultural Economics”, 2008, nr 59. 
Bandarzewski K., Umowa partnerstwa jako podstawa realizacji nowej perspektywy finansowania rozwoju regionalnego $w$ latach 2014-2020, [w:] Rozwój regionalny - instrumenty realizacji i rola samorzadu województwa, K. Bandarzewski, M. Stec (red.), Warszawa 2015.

Bańczyk W., ,, Miękkie prawo, ale prawo”, czyli o obowiązu przestrzegania soft law, „Internetowy Przegląd Prawniczy TBSP UJ", 2016, nr 1.

Beveridge F., Nott S., a Hard Look on the Soft Law, [w:] Lawmaking in the European Union, P. Craig, C. Harlow (red.), Boston 1998.

Będźmirowska P., Modernizacja gospodarstw rolnych, [w:] Prawo rolne, P. Czechowski (red.), Warszawa 2015.

Biczkowski M., Instrumenty wspólnej polityki rolnej jako czynnik wspierający rozwój obszarów wiejskich. Studium na przykładzie regionu kujawsko-pomorskiego, Toruń 2018.

Bieluk J., Łobos-Kotowska D., Kwoty mleczne jako przedmiot obrotu - wybrane zagadnienia, „Studia Iuridica Agraria”, Białystok 2011, t. 9.

Bieluk J., Łobos-Kotowska D., Płatności bezpośrednie, [w:] Prawo rolne, P. Czechowski (red.), Warszawa 2015.

Bieluk J., Zmiana paradygmatu prawa rolnego, „Studia Iuridica Agraria”, Białystok 2015, t. 13.

Bieńkowski W., Reaganomika i jej wpływ na konkurencyjność amerykańskiej gospodarki. Warszawa 1995.

Biernat J., Polska gospodarka w świetle niektórych kryteriów oceny konkurencyjności gospodarki, [w:] Konkurencyjność gospodarki Polski w warunkach integracji z Unia Europejska i globalizacji, J. Staszewski (red.), Warszawa 2004.

Blajer P., Amerykańskie family farms: status $i$ instrumenty wspierania przez instytucje federalne, [w:] Prawne mechanizmy wspierania i ochrony rolnictwa rodzinnego w Polsce i innych państwach Unii Europejskiej, P. Litwiniuk (red.), Warszawa 2015.

Blajer P., Ewolucja szczególnej regulacji obrotu gruntami rolnymi w ustawodawstwie hiszpańskim, „Studia Iuridica Agraria”, Białystok 2009, t. 9.

Blajer P., Gospodarstwa rodzinne w USA - status, znaczenie i aktualne problemy, „Studia Iuridica Agraria", Białystok 2014, t. 12.

Blajer P., Koncepcja prawna rolnika indywidualnego $w$ prawie polskim na tle porównawczym, Kraków 2009.

Blajer P., Pojęcia gospodarstwa rodzinnego i rolnika indywidualnego w ustawie o kształtowaniu ustroju rolnego z dnia 5 sierpnia 2015 r., „Krakowski Przegląd Notarialny”, 2016, nr 1.

Blajer P., Wymóg kwalifikacji rolniczych w obrocie nieruchomościami. Studium prawnoporównawcze, „Przegląd Prawa Rolnego”, 2008, nr 2.

Blajer P., Zmiana generacji w gospodarstwach rolnych $w$ Polsce $w$ świetle polityki rozwoju obszarów wiejskich (aspekty prawne), „Przegląd Prawa Rolnego”, 2010, nr 2 (7).

Błażejewska K., Klimatyczne wyzwania Wspólnej Polityki Rolnej po 2013 r., „Przegląd Prawa Rolnego", 2011, nr 8.

Błąd M., Reformy wspólnej polityki rolnej w Unii Europejskiej w latach dziewięćdziesiatych, „Acta Scientifica Academiae Ostroviensis", 2000, nr 6.

Bołtromiuk A., Przyczyny $i$ skutki wzrostu zainteresowania aspektem środowiskowym w polityce rolnej UE, „Roczniki Naukowe SERiA”, 2006, t. 8, z. 4.

Bossak J., Międzynarodowa konkurencyjność gospodarki polskiej - ujęcie instytucjonalne, [w:] H. Podedworny, J. Grabowiecki, H. Wnorowski, Konkurencyjność gospodarki polskiej a rola państwa przed akcesją do Unii Europejskiej, Białystok 2000. 
Bórawski P., Lewczyk A., Zróżnicowanie wyników ekonomicznych indywidualnych gospodarstw rolnych $w$ zależności od potencjatu konkurencyjnego, a zwłaszcza ziemi, „Roczniki Naukowe SERiA", 2008, t. 10, z. 3.

Bórawski P., Wykształcenie rolników i sytuacja ekonomiczna gospodarstw posiadajacych alternatywne dochody, „Zeszyty Naukowe SGGW. Problemy Rolnictwa Światowego”, 2010, t. 10 (2).

Brysiewicz K., Dofinansowanie ze środków europejskich w orzecznictwie Sądu Najwyższego i sqdów powszechnych, „Monitor Prawniczy”, 2014, nr 17.

Budzikowski M., Ograniczenia praw podmiotowych właściciela nieruchomości rolnej w prawie administracyjnym, „Studia Iuridica”, 2014, nr 58.

Budzinowski R., Formy prawne zmiany generacji inter vivos $w$ rolnictwie, [w:] Prawo rolne, P. Czechowski (red.), Warszawa 2011.

Budzinowski R., Międzynarodowy czynnik rozwoju prawa rolnego, „Przegląd Prawa Rolnego”, 2007, $\mathrm{nr} 2$.

Budzinowski R., Prawne pojęcie działalności pszczelarskiej, [w:] Prawo i Administracja, t. 2, R. Budzinowski (red.), Piła 2003.

Budzinowski R., Suchoń A., Relacja gospodarstwa rolnego i przedsiębiorstwa rolnego $w$ świetle publicznych mechanizmów ich wspierania, [w:] Prawne mechanizmy wspierania i ochrony rolnictwa rodzinnego w Polsce i innych państwach Unii Europejskiej, P. Litwiniuk (red.), Warszawa 2015.

Budzyńska A., Procesy restrukturyzacyjne charakteryzujace rynek cukru w Unii Europejskiej, „Problemy Rolnictwa Światowego”, 2013, nr 13.

Bukowski Z., Koncepcja zrównoważonego rozwoju w działalności publicznej, [w:] Administracja publiczna - człowiek a ochrona środowiska. Zagadnienia społeczno-prawne, M. Górski, J. Bucińska, M. Niedziółka, R. Stec, D. Strus (red.), Warszawa 2011.

Burczyk P., Gamrat D., Gałczyńska M., Saran E., Rola trwałych użytków zielonych w zapewnieniu stanu równowagi ekologicznej środowiska przyrodniczego, „Woda, Środowisko, Obszary Wiejskie", 2018, t. 18, z. 3.

Burgaz F.J., The Spanish Agricultural Insurance Scheme: National Experiences and Recommendations Looking at the CAP Post 2013, Brussels 2010.

Cardwell M., European Union Agricultural Policy and Practice: The New Challenge of Climate Change, „Environmental Law Review”, 2011, nr 4.

Chlebicka A., Falkowski J., Wołek T., Małe gospodarstwa rolne-charakterystyka, Warszawa 2009.

Cichalewska P., Brodecki S., Wptyw Programu Rozwoju Obszarów Wiejskich 2007-2013 na konkurencyjność polskiego rolnictwa, [w:] „Studia Iuridica Agraria”, Białystok 2012, t. 10.

Climate Change and Agriculture in the United States: Effects and Adaptation, C.L. Walthall (red.), „USDA Technical Bulletin”, 2012, nr 193.

Costato L., Wpływ wspólnotowego prawa rolnego na prawo rolne wewnętrzne, „Przegląd Prawa Rolnego", 2007, nr 1.

Czechowski P., Dostosowanie polskiego prawa rolnego i żywnościowego do prawa wspólnotowego po akcesji do Unii Europejskiej, Warszawa 2005.

Czechowski P., Korzycka-Iwanow M., Prutis S., Stelmachowski A., Polskie prawo rolne na tle ustawodawstwa Unii Europejskiej, Warszawa 2002.

Czechowski P., Korzycka-Iwanow M., Prutis S., Stelmachowski A., Polskie prawo rolne na tle ustawodawstwa Unii Europejskiej, Warszawa 1999.

Czechowski P., Lichorowicz A., Dzierżawa gruntów rolnych $w$ świetle standardów europejskich, „Podatki i Prawo Gospodarcze Unii Europejskiej”, 1999, nr 6. 
Czechowski P., Niewiadomski A., Europejskie rynki rolne [w:] Prawo rolne, A. Stelmachowski (red.), Warszawa 2009.

Czechowski P., Niewiadomski A., Europejskie rynki rolne, [w:] Prawo rolne, P. Czechowski (red.), Warszawa 2015.

Czechowski P., Niewiadomski A., Tendencje rozwoju polskiego prawa rolnego w zwiazku z nabyciem członkostwa Polski w Unii Europejskiej, „Studia Iuridica Agraria”, Białystok 2009, t. 7.

Czechowski P., Proces dostosowania polskiego prawa rolnego i żywnościowego do prawa Unii Europejskiej, Warszawa 2001.

Czechowski P., Reguly konkurencji oraz pomoc publiczna w rolnictwie, Warszawa 2001.

Czechowski P., Standardy harmonizacji prawa, [w:] Prawo polskie a prawo Unii Europejskiej, E. Piontek (red.), Warszawa 2003.

Czechowski P., Ziętara W., Konkurencja a regulacja w rolnictwie, Warszawa 1995.

Czekaj M., Wybrane problemy sukcesji gospodarstw rolnych w Polsce, „Prace Naukowe Uniwersytetu Ekonomicznego we Wrocławiu”, 2016, nr 439.

Czubak W., Poczta W., Sadowski A., Wplyw proponowanej reformy systemu dopłat bezpośrednich po 2013 roku na sytuacje polskiego rolnictwa, „Wieś i rolnictwo”, 2011, nr 4.

Czubak W., Sadowski A., Dostępność informacji oraz czynniki utrudniające ubieganie sięo dopłaty bezpośrednie, „Wieś i Rolnictwo”, 2010, nr 3.

Czubak W., Wykorzystanie funduszy Unii Europejskiej wspierajacych inwestycje w gospodarstwach rolnych, ,Journal of Agribusiness and Rural Development”, 2012, $\operatorname{nr} 3$ (25).

Czyzyk F., Ocena zużycia nawozów mineralnych $w$ gospodarstwach rolnych $w$ aspekcie ochrony środowiska, „Problemy Inżynierii Rolniczej”, 2011, nr 3.

Czyżewski A., Henisz A., Makroekonomiczne determinanty przemian strukturalnych $w$ rolnictwie, [w:] Nowoczesne zarządzanie przedsiębiorstwem, J. Stankiewicz (red.), Zielona Góra 2002.

Czyżewski B., Majchrzak A., Związek dochodów, cen i produktywności w rolnictwie $w$ Polsce - ujęcie makroekonomiczne, „Roczniki Naukowe Stowarzyszenia Ekonomistów Rolnictwa i Agrobiznesu", 2015, nr 17.

Czyżewski B., Śmigala M., Instytucjonalne przesłanki rozwoju gospodarstw mleczarskich w Polsce, ,Journal of Agribusiness and Rural Development”, 2012, nr 3 (25).

Czyżewski A., Wawrzyniak Ł., Wspólna Polityka Rolna Unii Europejskiej po reformie MacSharry'ego w warunkach różnych opcji polityki gospodarczej, „Wieś i Rolnictwo”, 2004, nr 4.

Dołęgowski T., Konkurencyjność a procesy integracyjne w Europie, Warszawa 2000.

Domańska M., Implementacja dyrektyw unijnych przez sady krajowe, Warszawa 2014.

Dudzińska M., Kocur-Bera K., Definicja matego gospodarstwa rolnego, „Infrastruktura i Ekologia Terenów Wiejskich", 2013, nr 1 (4).

Dzun W., Duże gospodarstwa rolne przed i po wejściu do UE, [w:] Polska wieś i rolnictwo w Unii Europejskiej. Dylematy i kierunki przemian, Warszawa 2008.

Emmis S., Competition and Regulation in Agriculture, OECD, „Journal of Competition Law and Policy", 2007, nr 2 (9).

European Competitiveness Report, European Commission, Luxemburg 2001.

Flis M., Nowe rozwiazania prawno-administracyjne $w$ zakresie zwalczania afrykańskiego pomoru świń, „Życie Weterynaryjne”, 2018, nr 93.

Foss J.N., Research in strategy, economics, and Michael Porter, „Journal of Management Studies”, 1996, nr 33.

Gała P., Ochrona bioróżnorodności jako determinanta Wspólnej Polityki Rolnej, „Studia Iuridica Lublinensia", 2017, t. 26. 
Gała P., Problematyka bioróżnorodności w nowym PROW na lata 2014-2020, „Studia Iuridica Agraria", Białystok 2015, t. 13.

Germanò A., Reforma Wspólnej Polityki Rolnej z 2003 r. i reżim płatności jednolitej, „Przegląd Prawa Rolnego", 2007, nr 1.

Germanò A., Strambi G., Wdrażanie Programów Rozwoju Obszarów Wiejskich we Włoszech na podstawie rozporządzenia 1305/2013, „Przegląd Prawa Rolnego”, 2016, nr 2 (19).

Giemza K., Wdrażanie funduszy europejskich w polskim rolnictwie na przykładzie Programu Rozwoju Obszarów Wiejskich na lata 2014-2020, „Studia z Polityki Publicznej”, 2017, nr 15.

Giersz Z., Instrument stabilizacji dochodów - nowy instrument zarządzania ryzykiem w perspektywie Wspólnej Polityki Rolnej po 2013 r., Warszawa 2011.

Ginter A., Kałuża H., Szarek S., Wiedza czy madrość? Czynniki kształtujące przewage konkurencyjna gospodarstw rolnych, „Wieś i Rolnictwo”, 2010, nr 4 (149).

Głodowska M., Gałązka A., Wpływ rolnictwa ekologicznego na środowisko w koncepcji rozwoju zrównoważonego, „Wieś i Rolnictwo”, 2017, nr 2 (175).

Gołębiewski T., TRANS'99:Wspólna Europa. Międzynarodowa konkurencyjność polskich przedsiębiorstw, Warszawa 1999.

Gorter H. De, Meilke K.D., Efficiency of alternative policies for the EC's Common Agricultural Policy, „American Journal of Agricultural Economics”, 1989, nr 7.

Gorynia M., Innowacyjność, produktywność i konkurencyjność gospodarki a międzynarodowa wspótpraca gospodarcza, „Ruch Prawniczy, Ekonomiczny i Socjologiczny”, 2018, z. 4.

Goździewicz-Biechońska J., Nowe paradygmaty ochrony ziemi jako zasobu środowiska w prawie rolnym, „Przegląd Prawa Rolnego”, 2017, nr 2 (21).

Goździewicz-Biechońska J., Planowanie przestrzenne wobec współczesnych tendencji rozwoju obszarów wiejskich, „Przegląd Prawa Rolnego”, 2015, nr 2 (17).

Goździewicz-Biechońska J., The role of agriculture in the circular economy (perspectives for legislation and policy), „Przegląd Prawa Rolnego”, 2016, nr 1 (18).

Goździewicz-Biechońska J., Zielona infrastruktura na obszarach wiejskich jako instrument polityki ochrony środowiska UE, „Studia Iuridica Lubliniensia”, 2017, t. 26, nr 1.

Góral J., Instrumenty wspierania gospodarstw rolniczych w Polsce, „Marketing i Zarządzanie”, 2016, nr 43.

Grębowiec M., Produkty regionalne i tradycyjne jako element budowania konkurencyjnej oferty produktów żywnościowych w Polsce i innych krajach Europy, „Zeszyty Naukowe Szkoły Głównej Gospodarstwa Wiejskiego w Warszawie Problemy Rolnictwa Światowego", 2017, t. 17, z. 2.

Grochowska R., Niespójność działań interwencyjnych na unijnym rynku mleka, „Zeszyty Naukowe Szkoły Głównej Gospodarstwa Wiejskiego w Warszawie Problemy Rolnictwa Światowego", 2017, t. 17, z. 3.

Grontkowska A., Frania M., Bagieński S., Ocena realizacji działania „ułatwianie startu młodym rolnikom” programu rozwoju obszarów wiejskich 2007-2013 wedlug województw, „Roczniki (Annals)", 2016, nr 6.

Gutiérez A.M., Ochrona rodzinnego gospodarstwa rolnego w prawie hiszpańskim, [w:] Prawne mechanizmy wspierania $i$ ochrony rolnictwa rodzinnego $w$ Polsce $i$ innych państwach Unii Europejskiej, P. Litwiniuk (red.), Warszawa 2015.

Habuda A., Prawne skutki utworzenia obszaru Natura 2000 z perspektywy właściciela nieruchomości, [w:] Gospodarowanie $w$ dolinach rzecznych na obszarach Natura 2000 - problemy działalności inwestycyjnej, B. Pawluśkiewicz (red.), Warszawa 2015. 
Hajdukiewicz A., Kierunki zmian w polskim eksporcie świeżych owoców $i$ warzyw $w$ kontekście embarga na przywóz niektórych produktów rolno-spożywczych do Rosji, „Przedsiębiorczość i Zarządzanie", 2018, nr 19.

Hajdukiewicz A., Kierunki zmian Wspólnej Polityki Rolnej Unii Europejskiej w kontekście negocjacji handlowych na forum WTO i Brexitu, „Horyzonty Polityki”, 2017, nr 8.

Harasim A., Madej A., Górnik A., Innowacyjność różnych typów rolniczych gospodarstw w opinii rolników z makroregionu Mazowsza i Podlasia, „Roczniki Naukowe Stowarzyszenia Ekonomistów Rolnictwa i Agrobiznesu", 2017, nr 19.

Harasimowicz A., Fundusze Strukturalne i Fundusz Spójności jako instrumenty realizacji polityki regionalnej Unii Europejskiej, Białystok 2012.

Harasym R., Pater R., Skica T., Konkurencyjność i rozwój Polski Wschodniej, „Samorząd Terytorialny", 2018, $\mathrm{nr} 5$.

Hawrylewicz-Łuka A., Spetnianie wymogów wzajemnej zgodności (cross-compliance) przy ubieganiu się przez rolników o płatności bezpośrednie jako poszanowanie środowiska naturalnego, [w:] Administracja publiczna - człowiek a ochrona środowiska. Zagadnienia społeczno-prawne, M. Górski, J. Bucińska, M. Niedziółka, R. Stec, D. Strus (red.), Warszawa 2011.

Hejbudzki M., Normatywne struktury funkcjonowania podmiotów gospodarczych w mechanizmie dopłat do prywatnego przechowywania na rynku wieprzowiny, „Studia Iuridica Lublinensia”, 2017, nr 26.

Hełdak M., Zasady nabywania gruntów pod drogi publiczne w Polsce, „Prace Naukowe Uniwersytetu Ekonomicznego we Wrocławiu", 2016, nr 418.

Holmes J.S., Translation theory, translation theories, translation studies, and the translator, [w:] Translated! Papers on Literary Translation and Translation Studies, J.S. Holmes (red.), Amsterdam 1998.

Hubbard J.L., The co-responsibility levy: a misnomer?, „Food Policy”, 1986, nr 11.

Instytucje Justyniana, przeł. C. Kunderewicz, Warszawa 1986.

Jachnik E., Prawne aspekty ochrony zapachowej jakości powietrza, „Przegląd Prawa Rolnego”, 2017, nr 1 .

Janowicz-Lomott M., Łyskwa K., Wspieranie rolnictwa $w$ USA z wykorzystaniem instrumentów ubezpieczeniowych (FARM BILL 2014), „Studia Oeceonomia Posnaniensia”, 2015, t. 3, nr 123.

Jarosz-Angowska A., Instrumenty regulacji rynków rolnych w uwarunkowaniach wspólnej polityki rolnej UE, ,Studia Ekonomiczne”, 2017, nr 312.

Jeżyńska B., Funkcja środowiskowa gospodarstw rolnych, [w:] Prawne aspekty gospodarowania zasobami środowiska. Korzystanie z zasobów środowiska, B. Rakoczy, M. Szalewska, K. Karpus (red.), Toruń 2014.

Jeżyńska B., Funkcje doradztwa rolniczego w europejskim partnerstwie innowacyjnym na rzecz wydajnego i zrównoważonego rolnictwa EPI-AGRI, 2016, Opinie i Ekspertyzy, Kancelaria Senatu Biuro Analiz i Dokumentacji.

Jeżyńska B., Obszary Natura 2000 w ramach Wspólnej Polityki Rolnej Unii Europejskiej, [w:] Problemy wdrażania systemu Natura 2000 w Polsce, A. Kaźmierska-Patrzyczna, M.A. Król (red.), Szczecin-Łódź-Poznań 2013.

Jeżyńska B., Organizacja rolniczej działalności wytwórczej w ramach klastra, „Studia Iuridica Agraria", Białystok 2011, t. 9.

Jeżyńska B., Pastuszko R., Pakiet legislacyjny WPR 2014-2020 w świetle podstaw prawa UE i prawa międzynarodowego. Kompleksowa analiza prawna, Biuro Analiz i Dokumentów, OE - 186, marzec 2012. 
Jeżyńska B., Proekologiczne instrumenty wsparcia zrównoważonego rozwoju obszarów Wiejskich, „Studia Iuridica Agraria”, Białystok 2012, t. 10.

Jeżyńska B., Proporcjonalność sankcji w działaniu PROW „,Ułatwianie startu młodym rolnikom”, [w:] Integracja europejska jako determinanta polityki wiejskiej. Aspekty prawne, P. Litwiniuk (red.), Warszawa 2017.

Jeżyńska B., Wizja systemu doradztwa rolniczego w kontekście propozycji legislacyjnych Komisji Europejskiej, Warszawa 2012, BAS - 2405/12A.

Jeżyńska B., Znaczenie i funkcje zasady cross-compliance w systemie rolniczych dopłat bezpośrednich, „Studia Iuridica Lubliniensia”, 2010, nr 13.

Jopek-Bosiacka A., Przekad prawny i sadowy, Warszawa 2008.

Joseph J.E., Indeterminacy, Translation and the Law, [w:] Translation and the Law, M. Morris (red.), Amsterdam/Philadelphia 1995.

Józwiak W., Zagrożenia przyrodniczo-klimatyczne dla gospodarstw rolnych osób fizycznych na tle ich sytuacji dochodowej, „Zagadnienia Ekonomiki Rolnej”, 2016, z. 3 (348).

Jóźwik B., Sagan M., Stępniewski T., Polityka spójności Unii Europejskiej. Doświadczenia, wnioski i rekomendacje na lata 2014-2020, Lublin 2012.

Judzińska A., Instrumenty wsparcia rolnictwa w ramach WPR, [w:] Wplyw Wspólnej Polityki Rolnej na rolnictwo, W. Łopaciuk (red.), Warszawa 2011

Jurcewicz A. [w:] Prawo i polityka rolna Unii Europejskiej, System prawa Unii Europejskiej. Podręcznik, A. Jurcewicz (red.), tom XXVI, Warszawa 2010.

Jurcewicz A., Charakterystyka wspólnej polityki rolnej, [w:] A. Jurcewicz, B. Kozłowska, E. Tomkiewicz, Polityka rolna Wspólnoty Europejskiej w świetle ustawodawstwa i orzecznictwa, Warszawa 1995.

Jurcewicz A., Komentarz do art. 39 Traktatu o funkcjonowaniu Unii Europejskiej, [w:] Komentarz do Traktatu o funkcjonowaniu Unii Europejskiej, t. I (art. 1-89), D. Miąsik, N. Półtorak (red.), Warszawa 2012.

Jurcewicz A., Kozłowska B., Tomkiewicz E., Wspólna Polityka Rolna. Zagadnienia prawne, Warszawa 2006.

Jurcewicz A., Przemiany własności w rolnictwie - kontekst systemowy z perspektywy prawa krajowego i unijnego, „Studia Prawnicze”, 2014, nr 1.

Jurcewicz A., Rola ,, miękkiego prawa” w praktyce i instytucjach Wspólnoty Europejskiej, [w:] Implementacja prawa integracji europejskiej $w$ krajowych porzadkach prawnych, C. Mik (red.), Toruń 1998.

Jurcewicz A., Soft law w prawie Wspólnot Europejskich, „Przegląd Legislacyjny”, 1997, nr 4.

Jurcewicz A., Tomkiewicz E., Wspólna Polityka Rolna po 2013 r., [w:] Z zagadnień prawa rolnego, cywilnego i samorzadu terytorialnego. Księga jubileuszowa Profesora Stanisława Prutisa, T. Mróz, J. Bieluk, A. Doliwa, A. Malarewicz-Jakubów (red.), Białystok 2012.

Jurcewicz A., Traktatowe podstawy unijnego prawa rolnego w świetle orzecznictwa. Zagadnienia wybrane, Warszawa 2012.

Jurcewicz A., Własność w ujęciu prawa wspólnotowego - zarys, „Studia Iuridica Agraria”, Białystok 2005 , t. 5.

Jurkowska-Gomułka A., Skoczny T., Wspólne reguły konkurencji Unii Europejskiej. System Prawa Unii Europejskiej, t. XXIV, J. Barcz (red.). Warszawa 2010.

Kaczorowska J., Rejman K., Halicka E., Wptyw certyfikatu rolnictwa ekologicznego na gotowość konsumentów do zapłaty wyższej ceny za owoce, „Handel Wewnętrzny”, 2018, nr 3 (374). 
Kagan A., Procesy dostosowawcze wielkotowarowych gospodarstw rolnych $w$ kontekście średniookresowego przeglądu WPR oraz polityki klimatyczno-środowiskowej UE, Instytut Ekonomiki Rolnictwa i Gospodarki Żywnościowej - Państwowy Instytut Badawczy, Warszawa 2018.

Kałuża H., Ginter A., Innowacje w gospodarstwach rolniczych młodych rolników, „Prace Naukowe Uniwersytetu Ekonomicznego we Wrocławiu. Agrobiznes", 2014, nr 361.

Kamerschen D.R., McKenzie R.B., Nardinelli C., Ekonomia, Warszawa 1991.

Kania J., System wiedzy i informacji rolniczej w rolnictwie polskim, [w:] Prace Naukowe Uniwersytetu Ekonomicznego we Wrocławiu, „Problemy Ekonomiczne i Społeczne. Agrobiznes”, 2014, nr 360.

Kapała A., Legal Determinants of Quality Policy for Agricultural Products and Foodstuffs, „Studia Iuridica Lublinensia", 2017, t. 26, nr 1.

Kapała A., Prawne determinanty polityki jakości produktów rolnych i środków spożywczych, „Studia Iuridica Lublinensia” 2017, t. 26, nr 1.

Karwat-Woźniak B., Gospodarstwa wysokotowarowe w rolnictwie chłopskim. Synteza wyników badań 2005-2009, Warszawa 2009.

Karwat-Woźniak B., Możliwości rozwojowe chłopskiego rolnictwa na przykładzie gospodarstw wysokotowarowych. Raport $n r$ 10, IERiGŻ, Warszawa 2005.

Kaźmierska-Patrzyczna A., Król M.A., Prawne instrumenty ochrony krajobrazu wiejskiego w ramach systemów wsparcia bezpośredniego do gruntów rolnych oraz rozwoju obszarów wiejskich na lata 2014-2020, „Acta Universitatis Carolinae - Iuridica”, 2015, nr 2.

Kielar B., Zarys translatoryki, Warszawa 2003.

Kielar B.Z., Language of the Law in the Aspect of Translation, Warszawa 1977.

Kiełbasa B., Education as a determinant of the implementation of innovation in agriculture in the light of empirical research, „Roczniki Naukowe SERiA”, t. XVIII (1).

Kiełbasa B., Puchała J., Innowacyjność młodych rolników i ich postawy wobec zmian na przykładzie gospodarstw rolnych położonych $w$ regionie rozdrobnionego rolnictwa, ,Roczniki Naukowe SERiA", 2015, t. XVII (1).

Kierzkowska D., Ttumaczenia prawnicze, Warszawa 2002.

Klastry w strategii rozwoju konkurencyjności na Mazowszu, A.Z. Nowak (red.), Warszawa 2009.

Kleinhanss W., Konkurencyjność głównych typów gospodarstw rolniczych w Niemczech, „Zagadnienia Ekonomiki Rolnej”, 2015, nr 1.

Klepacki B., Radochonska-Wasiewicz E., Znaczenie programów wspierania konkurencyjności w opinii kierowników małych $i$ średnich przedsiębiorstw, „Roczniki Naukowe Stowarzyszenia Ekonomistów Rolnictwa i Agrobiznesu”, 2017, t. 19, z. 4.

Klepacki B., Radochońska-Wasiewicz E., Sytuacja ekonomiczna małych i średnich przedsiębiorstw korzystających z programu wzrostu konkurencyjności, „Zeszyty Naukowe Szkoły Głównej Gospodarstwa Wiejskiego", 2017, nr 119.

Klepacki B., Wykształcenie jako czynnik różnicujacy zasoby, organizację $i$ wyniki ekonomiczne gospodarstw rolniczych, Warszawa 2005.

Klisowska A., Miejsce programów rolnośrodowiskowych $w$ polityce rolnej po integracji Polski z Unia Europejska, „Wieś i Rolnictwo”, 2001, nr 3.

Knecht D. De, Zrównoważony rozwój, „Innowacje” 2005 nr 25.

Kokoszka D., Gospodarstwo rolne. Zagadnienia konstrukcyjne, „Kwartalnik Prawa Prywatnego”, $2008, \mathrm{nr} 4$. 
Kondratowicz-Pozorska J., Konkurencyjność przedsiębiorstwa w świetle zrównoważonego rozwoju (na przykładzie ekologicznych gospodarstw rolnych), „Prace Naukowe Uniwersytetu Ekonomicznego we Wrocławiu", 2016, nr 417.

Korycińska A., Przyszłość cross-compliance w świetle dyskusji o systemie płatności bezpośrednich po 2013 r., Warszawa 2009.

Korzycka M., Kontekst historyczno-polityczny i naukowy normy konstytucyjnej o ustroju rolnym państwa polskiego, [w:] Państwo i Prawo. Księga Jubileuszowa Prokuratorii Generalnej Rzeczypospolitej Polskiej, L. Bosek (red.), Warszawa 2017.

Korzycka M., Ochrona własności rolniczej, Warszawa 1979.

Korzycka-Iwanow M., Obszar ryzyka w regulacjach prawa rolnego i żywnościowego, „Studia Iuridica Agraria”, Białystok 2001, nr 2.

Korzycka-Iwanow M., Prutis S., Własność rolnicza, [w:] Prawo rolne, P. Czechowski (red.), Warszawa 2015.

Korzycka-Iwanow M., Wojciechowski P., Żywność ekologiczna w prawie USA i Unii Europejskiej, „Studia Iuridica Agraria”, Białystok 2015, t. 13.

Kowalska A., Rolnictwo ekologiczne jako czynnik rozwoju zrównoważonej konsumpcji, „Journal of Agribusiness and Rural Development", 2015, nr 3 (37).

Kowalski A., Rembisz W., Ekonomia polityczna ryzyka cenowego w rolnictwie, [w:] Ryzyko w gospodarce żywnościowej - teoria i praktyka, J. Góral, M. Wigier (red.), Warszawa 2017.

Kowalski S., Dopłaty bezpośrednie w nowej perspektywie finansowej Unii Europejskiej na lata 2014-2020, „Zeszyty Naukowe PWSZ w Płocku. Nauki Ekonomiczne”, 2017.

Kowalski S., Oddziaływanie mechanizmów wspólnej polityki rolnej UE na przekształcenia strukturalne w polskim rolnictwie na przykładzie działania renty strukturalnej, „Zarządzanie Finansami i Rachunkowość", 2015, nr 3.

Kowalski S., Realizacja wspólnej polityki rolnej Unii Europejskiej i jej konsekwencje dla europejskiego rolnictwa, „Zeszyty Naukowe PWSZ w Płocku. Nauki Ekonomiczne” 2017, t. 25.

Kozińska A., Wdrażanie unijnego prawa ochrony środowiska w Polsce w latach 2001-2011, [w:] M. Rudnicki, A. Haładyj, K. Sobieraj, Dekada harmonizacji w prawie ochrony środowiska, Lublin 2011.

Kozłowski A., Żok K., Premie dla młodych rolników w PROW 2014-2020 - ocena naborów wniosków z lat 2015-2017, „Zagadnienia Doradztwa Rolniczego”, 2018, nr 1 (91).

Kozłowski D.S., Strategia zrównoważonego rozwoju Unii Europejskiej i jej implikacje dla Polski, „Biuletyn Polskiego Klubu Ekologicznego”, 2004.

Kozłowski K., Finansowanie budowy dróg publicznych w Polsce oraz wybrane prawne aspekty partnerstwa publiczno-prywatnego jako dodatkowej formy realizacji tych inwestycji, „Studia BAS”, 2017, $\mathrm{nr} 4$.

Kozłowski S., Strategia zrównoważonego rozwoju Unii Europejskiej i jej implikacje dla Polski, „Biuletyn Polskiego Klubu Ekologicznego”, 2004.

Kozłowski W., Surowiecki A., Kierunki rozwoju konstrukcji nawierzchni dróg wiejskich, „Problemy Inżynierii Rolniczej”, 2011, nr 19.

Krajowy plan działania na rzecz ograniczania ryzyka zwiąanego ze stosowaniem środków ochrony roślin na lata 2013-2017, Ministerstwo Rolnictwa i Rozwoju Wsi, Warszawa 2012.

Krasuski A., Kloepfer M., Die Entfaltung des Verhältnismäßigkeitsprinzips, [w:] Festgabe 50 Jahre Bundesverwaltungsgericht E. Schmidt-Aßmann (red.), Köln 2003.

Krebs W., Zur verfassungsrechtlichen Verortung und Anwendung des Übermaßverbotes, „Jura”, 2001 . 
Kremer E., Wybrane zagadnienia z problematyki rozwoju obszarów wiejskich, płatności bezpośrednich w orzecznictwie sadów administracyjnych, ,Studia Iuridica Agraria”, Białystok 2009, t. 7.

Król M.A., Instrumenty ochrony środowiska i ładu przestrzennego na obszarach wiejskich w Strategii na Rzecz Odpowiedzialnego Rozwoju w kontekście procesu integracji europejskiej, [w:] Integracja europejska jako determinanta polityki wiejskiej. Aspekty prawne, P. Litwiniuk (red.), Warszawa 2017.

Król M.A., „Zasada wzajemnej zgodności” - nowy instrument ochrony środowiska, [w:] Dekada harmonizacji w prawie ochrony środowiska, M. Rudnicki, A. Haładyj, K. Sobieraj (red.), Lublin 2011.

Król M.A., Bańkowska K., Wynagradzanie za środowiskowe dobra publiczne dostarczane przez rolnictwo, [w:] Dobra publiczne w administracji, M. Wożniak, M. Pierzchałka (red.), Warszawa 2014.

Król M.A., Ekologizacja Wspólnej Polityki Rolnej - zagadnienia prawne, „Zeszyty Naukowe Szkoły Głównej Gospodarstwa Wiejskiego w Warszawie. Polityki Europejskie, Finanse i Marketing", 2013, nr 10 (59).

Król M.A., Koncepcja rolnictwa ekologicznego, [w:] Prawo rolne. Problemy teorii i praktyki, R. Budzinowski, A. Zieliński (red.), Kluczbork 2002.

Król M.A., Legal protection framework of environmental law for agricultural production in Poland, „Zeszyty Naukowe SGGW. Polityki Europejskie, Finanse i Marketing” 2015, z. 13 (62).

Król M.A., Model doradztwa rolniczego $w$ Polsce na tle rozwiązań przyjętych $w$ wybranych krajach czlonkowskich Unii Europejskiej, Warszawa 2013.

Król M.A., Niewiadomski A., Rodzinne gospodarstwa rolne w systemie prawnym ochrony środowiska i zrównoważonego rozwoju, [w:] Ekonomiczne i prawne mechanizmy wspierania i ochrony rolnictwa rodzinnego, M. Podstawka (red.), Warszawa 2015.

Król M.A., Nowe rozwiąania prawne $w$ zakresie płatności $w$ ramach systemów wsparcia bezpośredniego, „Studia Iuridica Agraria”, Białystok 2015, t. 13.

Król M.A., Obszary o wysokich wartościach przyrodniczych i ich znaczenie w ochronie różnorodności biologicznej na obszarach wiejskich, [w:] Administracja publiczna a ochrona przyrody. Zagadnienia ekonomiczne, społeczne oraz prawne, M. Górski, D. Niedziółka, R. Stec, D. Strus (red.), Warszawa 2012.

Król M.A., Ocena modelu prawnej ochrony środowiska we Wspólnej Polityce Rolnej, „Studia Iuridica Lubliniensia", 2017, t. 26.

Król M.A., Przejawy europeizacji w prawie rolnym, „Studia Iuridica Agraria”, Białystok 2009, t. 7.

Król M.A., Rola gospodarstw rodzinnych w prawnej ochronie zasobów środowiska i różnorodności biologicznej, [w:] Prawne mechanizmy wspierania i ochrony rolnictwa rodzinnego $w$ Polsce i innych państwach Unii Europejskiej, P. Litwiniuk (red.), Warszawa 2015.

Król M.A., Rola programów rolnośrodowiskowych w ochronie obszarów cennych pod względem przyrodniczym, „Studia Prawno-Ekonomiczne”, 2012, nr 86.

Król M.A., Sytuacja prawna prowadzacego działalność rolnicza na obszarach Natura 2000, [w:] Problemy wdrażania systemu Natura 2000 w Polsce, A. Kaźmierska-Patrzyczna, M.A. Król (red.), Szczecin-Łódź-Poznań 2013.

Król M.A., Środowiskowy wymiar płatności w ramach systemów wsparcia bezpośredniego - zagadnienia prawne, [w:] Prawne instrumenty ochrony środowiska, B. Jeżyńska, E. Kruk, (red.), Lublin 2016.

Kuciński K., Konkurencyjność jako zagadnienie regionalne, Warszawa 1998. 
Kulawik J., Regulacje środowiskowe i innowacje a konkurencyjność, „Zagadnienia Ekonomiki Rolnej”, 2016, nr 1 (346).

Kurowska T., Gospodarstwo rodzinne czy gospodarstwo rozwojowe. Dylematy wyboru, [w:] Prawo rolne u progu Unii Europejskiej, S. Prutis (red.), Białystok 1998.

Kurowska T., Pomoc publiczna a ochrona środowiska $w$ procesie produkcji rolnej, [w:] Integracja europejska jako determinanta polityki wiejskiej. Aspekty prawne, P. Litwiniuk (red.), Warszawa 2017.

Kurowska T., Renesans własności rolniczej, „Przegląd Prawa Rolnego”, 2014, nr 2 (15).

Kurowska T., Zadania i funkcje instrumentów prawnych wspierania rozwoju obszarów wiejskich, „Studia Iuridica Agraria”, Białystok 2005, t. 4.

Kurowska T., Założenia konstrukcyjne umowy przyznania pomocy z Europejskiego Funduszu Rolnego na rzecz Rozwoju Obszarów Wiejskich, ,Studia Iuridica Agraria”, Białystok 2009, t. 7.

Kuś A., Witkowski P., Procedury celne w prawie celnym Unii Europejskiej, „Ius Novum”, 2019, nr 1 (13).

Lakner S., Schmitt J., Schüler S., Zinngrebe Y., Naturschutzpolitik in der Landwirtschaft: Erfahrungen aus der Umsetzung von Greening und der ökologischen Vorrangfläche 2015, Getynga 2016.

Leśkiewicz K., System jakości produktów rolnictwa ekologicznego. Aspekty prawne, Poznań 2011.

Leśkiewicz K., Lipińska I., Prawne aspekty kwalifikacji stosunku prawnego jako umowy kontraktacji w świetle orzecznictwa sądów powszechnych, „Studia Iuridica”, 2016, t. 64.

Lichorowicz A., Dzierżawa gruntów rolnych $w$ ustawodawstwie krajów zachodnioeuropejskich (studium prawno-porównawcze), „Zeszyty Naukowe Uniwersytetu Jagiellońskiego”, Warszawa, Kraków 1986, z. 118.

Lichorowicz A., Dzierżawa gruntów rolnych, [w:] Prawo rolne, A. Stelmachowski (red.), Warszawa 2009.

Lichorowicz A., O instytucji rodzinnego gospodarstwa rolnego - de lege ferenda, „Rejent”, 1996, $\mathrm{nr} 7-8$.

Lichorowicz A., Potrzeba prawnego uregulowania dzierżawy rolnej w Polsce (na podstawie doświadczeń krajów Unii Europejskiej), „Przegląd Prawa Rolnego”, 2010, nr 2 (7).

Lichorowicz A., Problematyka prawna harmonizacji polskiej regulacji obrotu gruntami rolnymi z ustawodawstwem Unii Europejskiej w przedmiocie struktur agrarnych, [w:] II Kongres notariuszy Rzeczypospolitej Polskiej. Referaty i opracowania, Poznań - Kluczbork 1999.

Lichorowicz A., Problematyka struktur agrarnych w ustawodawstwie Wspólnoty Europejskiej, Kraków 1996.

Lichorowicz A., Regulacja obrotu gruntami rolnymi wedtug ustawy z 11 kwietnia 2003 roku o kształtowaniu ustroju rolnego na tle ustawodawstwa agrarnego Europy Zachodniej, „Studia Iuridica Agraria", Białystok 2005, t. 4.

Lichorowicz A., Status prawny gospodarstw rodzinnych $w$ ustawodawstwie krajów Europy Zachodniej, Białystok 2000.

Lichorowicz A., Wspólna Polityka Rolna, [w:] J. Barcz, Prawo Unii Europejskiej, Warszawa 2004.

Lipińska I., Instrumenty ograniczania ryzyka produkcyjnego na rynku rolnym $w$ aspekcie globalizacji - wybrane zagadnienia prawne i ekonomiczne, „Zeszyty Naukowe Szkoły Głównej Gospodarstwa Wiejskiego Problemy Rolnictwa Światowego", 2016, nr 31.

Lipińska I., Nadzwyczajne środki wsparcia jako prawna ochrona unijnego rynku rolnego, „Przegląd Prawa Rolnego", 2017, nr 1 (20). 
Lipińska I., Nowe przepisy w zakresie organizacji wspólnotowego rynku rolnego, „Przegląd Prawa Rolnego", 2008, nr 1.

Lipińska I., Kontraktacja jako ogniwo łańcucha agrologistycznego, „Logistyka” 2012, z. 4.

Litwiniuk P., Aktywny rolnik - nowy beneficjent wsparcia bezpośredniego w ramach WPR, „Przegląd Prawa Rolnego", 2015, nr 1 (16).

Litwiniuk P., Prawna ochrona bioróżnorodności jako element polityki zrównoważonego rozwoju obszarów wiejskich, [w:] Prawne instrumenty ochrony środowiska, B. Jeżyńska, E. Kruk (red.), Lublin 2016.

Litwiniuk P., Program Rozwoju Obszarów Wiejskich jako dokument programowy i źródło prawa rolnego, Warszawa 2018.

Litwiniuk P., Uproszczenia Wspólnej Polityki Rolnej - nośny slogan czy absolutna konieczność?, „Studia Iuridica Agraria”, Białystok 2015, t. 13.

Litwiniuk P., Z problematyki nadużycia prawa przez beneficjenta Wspólnej Polityki Rolnej, „Przegląd Prawa Rolnego", 2014, nr 2 (15).

Litwiniuk P., O wybranych problemach dotyczacych zakresu wyłaczeń spod nowego reżimu prawnego obrotu nieruchomościami rolnymi w Polsce, „Studia Iuridica Lubliniensia”, 2017 , t. 26.

Lubiński M., Konkurencyjność gospodarki. Pojęcie i sposób mierzenia, [w:] Międzynarodowa konkurencyjność gospodarki Polski - uwarunkowania i perspektywy. Raporty. Studia nad konkurencyjnościa, Warszawa 1995.

Łacny J., Korekty finansowe nakładane przez Komisję Europejska na państwa członkowskie za niezgodne z prawem wydatkowanie funduszy Unii Europejskiej, Warszawa 2017.

Łobos D., Model gospodarstwa rodzinnego w ustawodawstwie Wspólnot Europejskich oraz w ustawodawstwach narodowych państw członkowskich Wspólnot Europejskich, [w:] Prawo rolne u progu Unii Europejskiej, S. Prutis (red.), Białystok 1998.

Łobos-Kotowska D., Charakter prawny kontroli w przepisach ustawy z dnia 20 lutego $2015 \mathrm{r}$. o wspieraniu rozwoju obszarów wiejskich z udziałem środków EFRROW na lata 2014-2020, [w:] Integracja europejska jako determinanta polityki wiejskiej. Aspekty prawne, P. Litwiniuk (red.), Warszawa 2017.

Łobos-Kotowska D., Planowanie inwestycji z udziałem środków EFRROW na obszarach wiejskich, „Studia Iuridica Agraria”, Białystok 2016, t. 14.

Łobos-Kotowska D., Stańko M., Dywersyfikacja działalności rolniczej jako instrument wspierania rozwoju gospodarstwa rodzinnego na przykladzie agroturystyki, [w:] Prawne mechanizmy wspierania i ochrony rolnictwa rodzinnego w Polsce i innych państwach Unii Europejskiej, P. Litwiniuk (red.), Warszawa 2015.

Łobos-Kotowska D., Wspótczesne funkcje umowy kontraktacji, [w:] Wspótczesne problemy prawa rolnego i cywilnego. Ksiega jubileuszowa Profesor Teresy Kurowskiej, D. Łobos-Kotowska, P. Gała, M. Stańko (red.), Warszawa 2018.

Makosz E., Przyszłość polskich jabłek, „Biuletyn Informacyjny ARR”, 2015, nr 3.

Mansholt S., The Mansholt Plan, ,Studies: An Irish Quarterly Review”, 1970, nr 59.

Marciniuk K., Pojęcie nieruchomości rolnej jako przedmiotu reglamentacji obrotu własnościowego, „Studia Iuridica Lubliniensia”, 2017, t. 26.

Marciniuk K., Prawne instrumenty ingerencji władzy publicznej w obrót nieruchomościami rolnymi jako środki ksztaltowania ustroju rolnego, Białystok 2019.

Marciniuk K., Problematyka rolna w świetle nowej umowy handlowej UE-USA (Transatlantic Trade \& Investment Agreement), ,Studia Iuridica Agraria”, Białystok 2013, t. 11. 
Marciniuk K., Rolnictwo wobec integracji europejskiej i globalizacji. Problematyka prawna, Warszawa 2013.

Marcysiak T., Prus P., Programy rolnośrodowiskowe jako instrument zrównoważonej modernizacji rolnictwa i obszarów wiejskich na przykładzie wybranych krajów UE, „Zeszyty Naukowe Szkoły Głównej Gospodarstwa Wiejskiego w Warszawie. Polityki Europejskie, Finanse i Marketing”, 2009 , nr 2.

Martinez J., Chancen und Risiken der Digitalisierung in der Landwirtschaft - die rechtliche Dimension, „Przegląd Prawa Rolnego”, 2016, nr 2 (19).

Martinez J., Das Greening der Gemeinsamen Agrarpolitik, „Natur und Recht“, 2013, nr 35.

Matulewska A., Gortych K., Translacyjne problemy wyrażania modalności denotycznej w tekstach aktów normatywnych w języku polskim, angielskim i greckim, [w:] Prawo i język, A. Mróz, A. Niewiadomski, M. Pawelec (red.), Warszawa 2009.

Matulewska A., Problemy przekładu terminologii wieloznacznej występujacej w polskich tekstach aktów normatywnych, [w:] Prawo i język, A. Mróz, A. Niewiadomski, M. Pawelec (red.), Warszawa 2009.

Matuszaka E., Polskie doradztwo rolnicze wobec nowych wyzwań w ramach UE, „Zagadnienia Doradztwa Rolniczego", 2011, nr 1.

Meredyk K., Przestanki wzrostu konkurencyjności gospodarki polskiej, [w:] Konkurencyjność gospodarki Polski w dobie integracji z UE i globalizacji, J. Bossak, W. Bieńkowski (red.), Warszawa 2001.

Mickiewicz A., Mickiewicz B., Charakterystyczne cechy nowego programu rozwoju obszarów wiejskich na lata 2014-2020, „Roczniki Naukowe Stowarzyszenia Ekonomistów Rolnictwa i Agrobiznesu", 20015, nr 17.

Mickiewicz B., Mickiewicz A., Problematyka matych gospodarstw rolnych $w$ rolnictwie polskim w latach 2014-2020 w świetle regulacji prawnych Parlamentu Europejskiego i Rady, „Problemy Drobnych Gospodarstw Rolnych", 2016, nr 1.

Miecznikowska J., Dyskusja nad kształtem Wspólnej Polityki Rolnej a ocena funkcjonowania reformy z lat 2003-2004, „Przegląd Europejski”, 2008, nr 1.

Mikołajczyk J., Współczesne funkcje obszarów wiejskich na tle koncepcji multifunkcjonalnego rolnictwa, „Studia Iuridica Agraria”, Białystok 2012, t. 10.

Mikołajczyk M., Francuska batalia o wspólna politykę rolna w okresie rządów generała Charles'a de Gaulle'a w latach 1958-1969, „Przegląd Zachodni”, 2014, t. 353, nr 4.

Milanowska D., Instrument modulacji w nowym systemie dopłat bezpośrednich, [w:] „Studia Iuridica Agraria", Białystok 2007, t. 6.

Milanowska D., Płatność za zazielenienie w nowym modelu dopłat bezpośrednich, „Studia Iuridica Agraria", Białystok 2015, t. 13.

Milewska M., Pomoc publiczna $w$ rolnictwie - wybrane aspekty, „Acta Scientiarum Polonorum-Oeconomia", 2009, nr 8.

Miś T., Przestrzenne zróżnicowanie wsparcia odnowy i rozwoju wsi z programów Unii Europejskiej, „Zagadnienia Doradztwa Rolniczego”, 2018, nr 3 (93)

Moro D., Sckokai P., Modelling the CAP arable crop regime in Italy: degree of decoupling and impact of Agenda 2000, „Cahiers d'Economie et de Sociologie Rurales”, 1998, nr 53.

Nadler J., Dzierżawa, [w:] Komentarz do Kodeksu cywilnego, E. Gniewek (red.), Warszawa 2011.

Nawrotek E., Działanie rolno-środowiskowo-klimatyczne jako instrument ochrony środowiska w rolnictwie, [w:] Prawne instrumenty ochrony środowiska, B. Jeżyńska, E. Kruk (red.), Lublin 2016. 
Neubert A., Text linguistics of Translation, The textual Approach to Translation, Birmingham 1996. Nieruchomości rolne w praktyce notarialnej, P. Księżak, J. Mikołajczyk (red.), Warszawa 2017.

Niewiadomska A., Konkurencyjność jako determinanta prawna europejskiej polityki rolnej, „Studia Iuridica", 2017, t. 72.

Niewiadomska A., Konkurencyjność w rolnictwie - wybrane aspekty, [w:] Wpływ funduszy strukturalnych na poprawę konkurencyjności polskiego rolnictwa, A.Z. Nowak (red.), Warszawa, 2013.

Niewiadomska A., Środowisko i konkurencja - Wspólna Polityka Rolna po 2020 r., „Studia Iuridica", 2018, t. 78.

Niewiadomski A., Prośrodowiskowe determinanty polskiej i europejskiej polityki rolnej, „Studia Iuridica Lublinensia", 2017, t. 26.

Niewiadomski A., Publicznoprawny i prywatnoprawny konflikt interesów na przykładzie Europejskiej Sieci Ekologicznej Natura 2000, Warszawa 2017.

Niewiadomski A., Rola aktów planistycznych w obrocie nieruchomościami rolnymi, [w:] Księga Jubileuszowa ku czci profesor Teresy Kurowskiej ,,Współczesne problemy prawa rolnego i cywilnego”, D. Łobos-Kotowska (red.), Katowice 2018.

Niewiadomski A., The direct payments system in European and Polish agriculture with particular emphasis on the greening policy, „Studia Iuridica”, 2016, t. 66.

Nowak A., Kijek T., Wójcik E., Wpływ wyksztatcenia rolników na produktywność pracy w towarowych gospodarstwach rolnych w Polsce, ,Roczniki Naukowe Stowarzyszenia Ekonomistów Rolnictwa i Agrobiznesu", 2016, nr 18.

Ogólna ocena pakietu legislacyjnego WPR na lata 2014-2020 i założenia do Stanowiska Rza$d u R P$.

Oleszko A., ,Dziedziczenie” kwot produkcyjnych oraz płatności w rolnictwie, [w:] „Annales Universitatis Mariae Curie-Skłodowska", Lublin, vol. LII/LIII, sectio G, 2005-2006.

Ołowski J., Trajer M., Unijny system regulacji wsparcia rynków rolnych, ze szczególnym uwzględnieniem instrumentów wdrażanych przez Agencję Rynku Rolnego, „Studia BAS” 2016, $\mathrm{nr} 48$.

Osdoba W., Kształtowanie jednolitej wspólnej regulacji rynków rolnych w Unii Europejskiej i Polsce, ,Studia Iuridica”, 2017, t. 72.

Pastuszko R., Kwalifikacja prawna umów zawieranych $w$ zwiąku z przekazaniem gospodarstwa rolnego w celu uzyskania świadczeń emerytalno-rentowych, [w:] Obrót gospodarczy w prawie rolnym, B. Jeżyńska (red), Lublin 2009.

Pawlak J., Efektywność środków trwałych mechanizacji w rolnictwie polskim $w$ latach 1995-2013, „Problemy Inżynierii Rolniczej”, 2016, z. 24.

Pejsak Z., Pomorska-Mól M., Program eradykacji wirusa afrykańskiego pomoru świń realizowany w Hiszpanii w latach 1985-1995, „Życie Weterynaryjne”, 2018, nr 93.

Petit M., Viallon J.B., Reflexions sur le plan Mansholt, „Economie rurale”, 1970, nr 86.

Pietrkiewicz K., Zajdel M., Michalcewicz-Kaniowska M., Wdrażanie programu „Owoce $i$ warzywa w szkole” jako element profilaktyki zdrowotnej w Polsce, „Marketing i Rynek”, 2015, nr 10.

Pietruk M., Nowe tendencje wsparcia rolnictwa ekologicznego, „Studia Iuridica Agraria”, Białystok 2017, nr 15.

Pietrzak M., Paliszkiewicz J., Klepacki B., The application of the balanced scorecard (BSC) in the higher education setting of a Polish university, „Online Journal of Applied Knowledge Management", 2015, t. 3, nr 1. 
Pietrzykowski R., Wicki L., Regionalne zróżnicowanie wykorzystania środków z programów Wspólnej Polityki Rolnej na modernizację rolnictwa, „Roczniki Naukowe Rolnictwa” Seria G, 2011, z. 4.

Pisuliński J., O niektórych osobliwościach obrotu nieruchomościami rolnymi, „Rejent”, 2016, nr 5. Poczta W., Change in agriculture with particular focus on structural transformations, [w:] J. Wilkin, I. Nurzyńska, Rural Poland 2012 Rural Development Report, Warszawa 2012.

Poczta W., Sadowski A., Wpływ proponowanej reformy systemu dopłat bezpośrednich po 2013 roku na sytuacje polskiego rolnictwa, „Wieś i Rolnictwo”, 2011, nr 4.

Poczta W., Siemański P., Konkurencyjność rolnictwa polskiego po przystapieniu do Unii Europejskiej, Poznań 2010.

Poczta W., Średzińska J., Mrówczyńska-Kamińska A., Determinanty dochodów gospodarstw rolnych Unii Europejskiej wedtug typów rolniczych, ,Zeszyty Naukowe SGGW, Ekonomika i Organizacja Gospodarki Żywnościowej”, 2009, nr 76.

Poczta W., Średzińska J., Standar A., Sytuacja finansowa gospodarstw rolnych krajów UE wedtug potencjału produkcyjnego, ,Journal of Agribusiness and Rural Development”, 2008, nr 10.

Poczta W., Wspólna Polityka Rolna po 2013 roku - wizja zmian, [w:] Projekty inwestycyjne w agrobiznesie a zasady Wspólnej Polityki Rolnej po 2013 roku, A. Czyżewski, W. Poczta (red.), Poznań 2011.

Podstawka M., Ginter A., Sytuacja dochodowa gospodarstw rolniczych w warunkach różnego poziomu rozwoju rolnictwa, „Roczniki Naukowe Stowarzyszenia Ekonomistów Rolnictwa i Agrobiznesu SERiA", 2006, t. 8, z. 1.

Porter M., Nicholas A., McGahan A., An Interview with Michael Porter, „The Academy of Management Executive (1993-2005)", 2020.

Porter M.E., Competitive advantage: Creating and sustaining superior performance, New York 2008.

Porter M.E., Kramer M.R., The link between competitive advantage and corporate social responsibility, „Harvard Business Review”, 2006, nr 84.

Porter M.E., Millar V.E., How information gives you competitive advantage, New York 1985.

Porter M.E., The Competitive Advantage of Nations, New York 1990, za: R.J. Stimson, R.R. Stough, R.H. Roberts, Regional Economic Development. Analysis and Planning Strategy, Berlin 2006.

Poździk R., Zasady wdrażania funduszy unijnych w latach 2014-2020, „Europejski Przegląd Sądowy", 2014, nr 12.

Prawo i polityka rolna Unii Europejskiej, A. Jurcewicz (red.), Warszawa 2010.

Prutis S., Dobór instrumentów prawnych służacych wsparciu rozwoju obszarów wiejskich, „Studia Iuridica Agraria”, Białystok 2009, t. 7.

Prutis S., Formy prawne dysponowania Zasobem Własności Rolnej Skarbu Państwa, [w:] Prawo rolne, A. Stelmachowski (red.), Warszawa 2006.

Prutis S., Instrumenty prawne wsparcia rozwoju rolnictwa ze środków UE ( $w$ świetle orzecznictwa Wojewódzkiego Sąu Administracyjnego w Białymstoku), „Studia Iuridica Agraria”, Białystok 2007, t. 6 .

Prutis S., Ochrona środowiska za pomoca instrumentów prawno-finansowych Wspólnej Polityki Rolnej, „Studia Iuridica Agraria”, Białystok 2015, t. 13.

Prutis S., Regulacje prawne produkcji ekologicznej w rolnictwie polskim, „Studia Iuridica Agraria”, Białystok 2013, t. 11.

Przybyciński T., Polityka konkurencji a ład rynkowy, Warszawa 2002.

Puślecki D., Prawne pojęcie gospodarstwa rodzinnego, „Zeszyty Naukowe SERiA”, 2016, nr 2. 
Pytlak P., Znaczenie i charakter umów w systemie mechanizmów regulujacych branżowe rynki rolne, ,Rejent”, 2006, nr 3.

Reforma wspólnej organizacji rynku wina - dotychczasowe postępy (przedstawione na mocy art. 287 ust. 4 akapit drugi TFUE), Sprawozdanie specjalne, Europejski Trybunał Obrachunkowy, 2012, $\mathrm{nr} 7$.

Reiss K., Vermeer H.J., Grundlegung einer allgemeinen Translationstheorie, Tübingen 1984.

Rocznik statystyczny rolnictwa $2011 \mathrm{r}$.

Rocznik statystyczny rolnictwa $2018 \mathrm{r}$.

Różański K., Prawne formy wsparcia działalności pszczelarskiej $w$ świetle rozporządzenia 1308/2013 ustanawiajacego wspólna organizację rynków produktów rolnych, „Studia Iuridica Lublinensia", 2017, t. 26.

Różne formy pomocy klęskowej dla rolników i rybaków, „Biuletyn Informacyjny MRiRW”, 2018, nr 9.

Ruano T.V., Repercusión del Avance Tecnológico en la Ampliación del Comercio de Productos Agroalimentarios en un Mercado Globalizado, „Przegląd Prawa Rolnego”, 2017, nr 2 (21).

Runowski H., Rolnictwo ekologiczne - rozwój czy regres, „Roczniki Nauk Rolniczych”, Seria G, 2009, nr 96.

Runowski H., Zróżnicowanie dochodów ludności rolniczej między krajami Unii Europejskiej i kierunki ich zmian, „Wieś i Rolnictwo”, 2018, nr 179.

Ryznar J., Doradztwo rolnicze w zarysie, Wrocław 1995.

Sánchez-Vizcaíno J.M., Mur L., Martínez-López B., African swine fever (ASF): five years around Europe, „Veterinary Microbiology”, 2013, nr 165.

Šarčević S., The new approach to legal translation, The Hague 2000.

Say J.B., Le Traité d'économie politique, Paris 1803.

Say J.B., Traktat o ekonomii politycznej czyli Prosty wyktad sposobu, w jaki się tworza, rozdzielaja i spożywaja bogactwa, Warszawa 1960.

Schmidt S.J., Texttheorie. Probleme einer Linguistik der sprachlichen Kommunikation, München 1976.

Skłodowski P., Bielska A., Właściwości i urodzajność gleb Polski - podstawa do kształtowania relacji rolno-środowiskowych, „Woda, Środowisko, Obszary Wiejskie” 2009, t. 9, z. 4.

Skubisz R., Gała P., Całka E. Prawo własności przemystowej, Warszawa 2017.

Słodowa-Hełpa M., Konkurencyjność - główne wyzwanie dla polskiego sektora rolno-żywnościowego w zintegrowanej Europie. [w:] Rolnictwo polskie we Wspólnej Polityce Rolnej Unii Europejskiej, Z.W. Puślecki, M. Walkowski (red.), Poznań 2004.

Słodowa-Hełpa M., Wieś i rolnictwo $w$ regionalnych $i$ lokalnych strategiach rozwoju, [w:] Wieś i rolnictwo w procesie integracji w UE, E. Kośmicki, H. Januszek, W. L. Janik (red.), Poznań 1998.

Sługocki W., Rola funduszy Unii Europejskiej w budowaniu konkurencyjności polskich regionów, „Marketing i Rynek”, 2016, z. 10.

Soliwoda M., Kulawik J., Góral J., Stabilizacja dochodów rolniczych: perspektywa międzynarodowa Unii Europejskiej i Polski, „Wieś i Rolnictwo”, 2016, nr 3.

Sozański J., Reformy Wspólnej Polityki Rolnej i prawa rolnego Unii Europejskiej po 1990 roku, „Ius Novum”, 2011, nr 1.

Sprawozdanie specjalne Europejskiego Trybunału Obrachunkowego nr 10/2017 nt. Unijne wsparcie dla młodych rolników powinno być lepiej ukierunkowane. Tak aby zapewniało rzeczywisty wktad w wymiane pokoleń. 
Srivastara I., Batie S.S., Norris P.E., The Porter Hypothesis, Property Rights, and Innovation Offstets: The Case of Southwest Michigan Pork Producer, Submitted for the Annual Meeting of the American Agricultural Economic Association, Nashville, Tennesse, August 8-11 1999.

Stacherzak A., Hełdak M., Kazak J., Obciążenia finansowe gmin kosztami realizacji dróg, „Prace Naukowe Uniwersytetu Ekonomicznego we Wrocławiu", 2014, nr 331.

Stankiewicz D., Ograniczenia $w$ obrocie gruntami rolnymi $w$ wybranych krajach Unii Europejskiej $w$ aspekcie prac nad stosownymi zmianami $w$ ustawodawstwie polskim, BAIS 2002, nr 886.

Stead D.R., The Mansholt Plan Forty Years On Le plan Mansholt quarante ans après Der Mansholt-Plan vierzig Jahre später, „EuroChoices”, 2007, nr 6.3.

Stefańska K., Model indywidualnego gospodarstwa rolnego w świetle znowelizowanego kodeksu cywilnego, „Państwo i Prawo”, 1992, nr 3.

Stefańska K., Pojęcia „nieruchomość rolna” $i$,gospodarstwo rolne” w ujęciu kodeksu cywilnego i ich znaczenie dla legislacji prawnorolnej, „Studia Iuridica Agraria”, Białystok 2009, t. 7.

Stefko O., Podstawowe zasoby gospodarstwa rolniczego $i$ ich zagospodarowania, [w:] Podstawy wiedzy o rolnictwie i agrobiznesie, M. Kozera, R. Ryś-Jurek, M. Tabert (red.), Poznań 2012.

Stelmachowski A., Agencje interwencyjne: Agencja Rynku Rolnego oraz Agencja Restrukturyzacji i Modernizacji Rolnictwa, [w:] Prawo rolne, A. Stelmachowski (red.), Warszawa 2009.

Stelmachowski A., Kontraktacja produktów rolnych, Warszawa 1960.

Stelmachowski A., Kontraktacja, [w:] System prawa prywatnego, t. 7: Prawo zobowiazań, J. Rajski (red.), Warszawa 2004.

Stelmachowski A., Modele prawnych instrumentów polityki rolnej, [w:] Prawo rolne, A. Stelmachowski (red.), Warszawa 2005.

Stelmachowski A., Treść i wykonywanie prawa własności, [w:] System Prawa Prywatnego, Prawo rzeczowe, T. Dybowski (red.), Warszawa 2007.

Stelmachowski A., Współczesne zróżnicowanie własności, „Studia Iuridica Agraria”, Białystok 2002 , t. 3.

Stelmachowski A., Zdziennicki B., Prawo rolne, Warszawa 1987.

Stobiecki S., System gromadzenia danych o sprzedaży i zużyciu środków ochrony roślin w Polsce na tle wymogów Unii Europejskiej. Stan obecny i perspektywy, „Postęp w Ochronie Roślin”, 2006, $\mathrm{nr} 46$ (1).

Stoksik J., Formy pomocy unijnej dla matych gospodarstw rolnych w Polsce, „Zeszyty Prawnicze”, 2016, nr 15.

Suchoń A., Dairy cooperatives as milk purchasing and processing entities in a milk products supply chain, „Logistyka”, 2014, nr 6.

Suchoń A., Dzierżawa gruntów rolnych a rozwój obszarów wiejskich, „Studia Iuridica Agraria”, Białystok 2007, t. 6.

Suchoń A., Dzierżawa gruntów rolnych jako instrument kształtowania ustroju rolnego, „Studia Iuridica Agraria", Białystok 2005, t. 4.

Suchoń A., Funkcjonowanie rynku mleka po likwidacji kwotowania - wybrane aspekty prawne, „Studia Iuridica Agraria, Białystok 2016, t. 14.

Suchoń A., Grupy producentów rolnych jako instrument rozwoju agrologistyki, „Logistyka”, 2012.

Suchoń A., Rechtliche und ökonomische Aspekte des Milchmarkts in Polen - aktueller Stand und Entwicklungsperspektiven, „Agrar und Umweltrecht”, 2014, z. 1.

Suchoń A., W kwestii nowego modelu spółdzielczości rolniczej, „Przegląd Prawa Rolnego”, 2013, nr $1(12)$. 
Suchoń A., Wpływ miejscowego planu zagospodarowania przestrzennego na prawne formy dysponowania nieruchomościami rolnymi, ,Studia Iuridica Agraria”, Białystok 2016, t. 14.

Suchoń A., Z prawno-ekonomicznej problematyki organizacji rynku mleka, „Przegląd Prawa Rolnego", 2014, nr 1 (14).

Sulewski P., Czekaj S., Zmiany klimatyczne oraz instytucjonalne a przewidywane wyniki ekonomiczne gospodarstw, „Zagadnienia Ekonomiki Rolnej” 2015, nr 1.

Szajner P., Ocena wpływu likwidacji kwot mlecznych na konkurencyjność polskiego mleczarstwa w kontekście teorii ekonomii, ,Zeszyty Naukowe Szkoły Głównej Gospodarstwa Wiejskiego w Warszawie. Problemy Rolnictwa Światowego“, 2012, nr 12 (27).

Szajner P., Wpływ likwidacji kwot mlecznych i zmian regulacji rynku mleka na perspektywy rozwoju polskiego mleczarstwa, IERiGŻ.

Szajner P., Wplyw reformy regulacji rynku cukru w UE na efektywność polskiego przemysłu cukrowniczego, „Prace Naukowe Uniwersytetu Ekonomicznego we Wrocławiu”, 2012, nr 246.

Szewczyk M., Ingerencja publicznoprawna w prawo własności jednostki w demokratycznym państwie prawnym, [w:] Jednostka w demokratycznym państwie prawa, J. Filipek (red.), Bielsko-Biała 2003.

Szydło M., Konkurencja regulacyjna w prawie spółek, Warszawa 2008.

Szydłowski J., Szydłowska B., Zmiany w strukturze obszarowej gospodarstw rolnych oraz dzierżawa i sprzedaż ziemi, [w:] Przemiany strukturalne w gospodarce żywnościowej regionu. Materiaty konferencyjne, Barzkowice 1994.

Szymańska M.E., Zasada zrównoważonego rozwoju rolnictwa w świetle uregulowań gatęzi prawa i polityki rolnej, ,Studia Iuridica Lubliniensa”, 2016, t. 25, nr 1.

Śmiechowska M., Autentyczność jako kryterium zapewnienia jakości żywności, „Annales Academiae Medicae Gedanensis", 2013, t. 43, nr 1.

Tallia C., Fornabaio L., The new decrees regarding mandatory origin labeling in France and Italy: some guidelines, „Dritto Agrario”, 2017, z. 1.

Tańska-Hus B., Dzierżawa rolnicza jako instrument przekształceń strukturalnych $w$ rolnictwie, Wrocław 2000.

Tańska-Hus B., Renty strukturalne jako instrument poprawy struktury obszarowej rolnictwa i przyśpieszenia wymiany pokoleń, „Studia Iuridica Agraria”, Białystok 2012, t. 10.

Tarnowska A., Środki obrotowe a wielkość produkcji wybranych ziemiopłodów $w$ dolnoślaskich gospodarstwach rolnych na tle kraju w latach 1999-2014, „Optimum. Studia Ekonomiczne”, 2016, $\mathrm{nr} 4$ (82).

Tereszczuk M., Instrumenty polityki handlowej Unii Europejskiej a polski handel zagraniczny produktami rolno-spożywczymi, „Prace Naukowe Uniwersytetu Ekonomicznego we Wrocławiu”, 2016, $\mathrm{nr} 449$.

Tereszczuk M., Subsydiowanie eksportu produktów rolno-spożywczych - zakres i znaczenie, „Finanse, Rynki Finansowe, Ubezpieczenia", 2016, nr 81.

The world competitiveness report, www.imd.org.

Theimeyer G., The failure of Green Pool and the success of the CAP, [w:] Fertile Ground for Europe? The History of European Integration and the Common Agricultural Policy science 1945, K.K. Patel (red.), Baden-Baden 2009.

Tomczak F., Ewolucja wspólnej polityki rolnej UE i strategia rozwoju rolnictwa polskiego, Warszawa 2009.

Tomecki M., Odpowiedzialność odszkodowawcza państwa z tytułu rozwoju infrastruktury drogowej, „Zeszyty Naukowe Uniwersytetu Ekonomicznego w Krakowie”, 2018, nr 975 (3). 
Tomkiewicz E., Bocheński M., Polityka rozwoju obszarów wiejskich w perspektywie lat 2014-2020 w kontekście nowych wyzwań, „Studia Iuridica Agraria”, Białystok 2012, t. 10.

Tomkiewicz E., Limitowanie produkcji w ustawodawstwie rolnym Wspólnoty Europejskiej, Warszawa 2000.

Tomkiewicz E., Sprzedaż państwowych nieruchomości rolnych w aspekcie ulepszania struktur rolnych, „Wieś i Rolnictwo”, Warszawa 1994, nr 1.

Tomkiewicz E., Wspólna polityka rolna po reformie z 2003 r., „Studia Iuridica Agraria”, Białystok 2005, t. 5.

Trajer M., Dopłaty do prywatnego przechowywania wieprzowiny jako forma interwencji rynkowej, „Roczniki Naukowe Stowarzyszenia Ekonomistów Rolnictwa i Agrobiznesu”, 2013, nr 4.

Trajer M., Krzyżanowska K., Program „Owoce w szkole” - realizacja i skuteczność w kształtowaniu nawyków żywieniowych u dzieci, ,Roczniki Ekonomii Rolnictwa i Rozwoju Obszarów Wiejskich”, 2012, nr 99.

Trajer M., Krzyżanowska K., Rolnictwo ekologiczne w Polsce i perspektywy jego rozwoju w kontekście PROW 2014-2020, „Turystyka i Rozwój Regionalny”, 2017, nr 8.

Trembecka A., Wplyw nieuregulowanych stanów prawnych nieruchomości na proces ustalania odszkodowań za nieruchomości wywłaszczone pod drogi, „Świat Nieruchomości”, 2017, nr 2.

Trojanowski Z., Prawne pojęcie producenta rolnego wedlug ustawy o krajowym systemie ewidencji producentów, ewidencji gospodarstw rolnych oraz ewidencji wniosków o przyznanie płatności w świetle orzecznictwa, „Przegląd Prawa Rolnego”, 2013, nr 1 (12).

Truszkiewicz Z., Wplyw planowania przestrzennego na pojęcie nieruchomości rolnej w rozumieniu Kodeksu cywilnego, „Studia Iuridica Agraria”, Białystok 2007, t. 6.

Trzcinski G., Pożyczka M., Duk K., Wpływ infrastruktury drogowej na zagospodarowanie obszarów wiejskich, „Studia i Materiały Centrum Edukacji Przyrodniczo-Leśnej”, 2016, nr 18.

Ura E., Heliniak K., Ograniczenia własności nieruchomości w administracyjnym prawie materialnym, [w:] Jednostka wobec działań administracji publicznej, E. Ura (red.), Rzeszów 2001.

Wiatrak A., Dochody ludności rolniczej (tworzenie, podziat, funkcje), „Ruch Prawniczy, Ekonomiczny i Socjologiczny" 1981, z. 1.

Wiatrak A., Doradztwo rolnicze w literaturze - stan badań krajowych i europejskich, [w:] Publiczne doradztwo rolnicze wobec wyzwań przyszłości i oczekiwań mieszkańców wsi, J. Kania, L. Leśniak (red.), Kraków 2013.

Wieliczko B., Czy warto stosować instrumenty finansowe w programach rozwoju obszarów wiejskich, „Zeszyty Naukowe SGGW w Warszawie. Problemy Rolnictwa Światowego”, 2016, nr $16(1)$.

Wieliczko B., Mechanizmy oddziaływania funduszy strukturalnych na konkurencyjność polskiego rolnictwa, [w:] „Studia Iuridica Agraria”, Białystok 2012, t. 10.

Wieliczko B., Zmiany $w$ WPR na lata 2014-2020 a modernizacja polskiej wsi i rolnictwa, ,Journal of Agribusiness and Rural Development", 2015, nr 3.

Wieliczko B., Zrównoważenie rolnictwa UE a WPR i strategia „Europa 2020, „Prace Naukowe Uniwersytetu Ekonomicznego we Wrocławiu”, 2016, nr 416.

Wierzbowski B., Aspekty przestrzenne ksztattowania ustroju rolnego, „Studia Iuridica Agraria”, Białystok 2016, t. 14.

Więznowska K., Wspólna polityka rolna - instrumenty interwencji, „Prace Naukowe Akademii Ekonomicznej we Wrocławiu", 2002, nr 958.

Wigier W., Wspólna Polityka Rolna po 2013 roku-zagadnienia wybrane, Warszawa 2013. 
Wilkin J., Kierunki i uwarunkowania wykorzystania instrumentów Wspólnej Polityki Rolnej w odniesieniu do polskiego rolnictwa i obszarów wiejskich, „Wieś i Rolnictwo”2003, nr 1.

Wilkin J., Ziemia rolnicza - dobro wielofunkcyjne, „Wieś i Rolnictwo”, 2014, nr 162.

Witkowski P., Instrumenty polityki celnej Unii Europejskiej, Lublin 2016.

Wojciechowski P., Charakter prawny Programu Rozwoju Obszarów Wiejskich, [w:] Prawo rolne, P. Czechowski (red.), Warszawa 2017.

Wojciechowski P., Gospodarstwo rodzinne jako gospodarstwo ekologiczne w prawie polskim i prawie UE, [w:] Prawne mechanizmy wspierania i ochrony rolnictwa rodzinnego $w$ Polsce i innych państwach Unii Europejskiej, P. Litwiniuk (red.), Warszawa 2015.

Wojciechowski P., Infrastruktura telekomunikacyjna w rozwoju obszarów wiejskich, „Studia Iuridica Agraria", Białystok 2016, t. 14.

Wojciechowski P., Nadzór nad żywnością GMO w kontekście umowy CETA, „Bezpieczeństwo i Higiena Żywności” 2016, nr 4.

Wojciechowski P., Niewiadomski A., Modernizacja gospodarstw rolnych, [w:] Prawo rolne, P. Czechowski (red.), Warszawa 2011.

Wojciechowski P., Odpowiedzialność administracyjna i karna beneficjentów pomocy z Programu Rozwoju Obszarów Wiejskich, „Studia Iuridica Agraria”, Białystok 2012, t. 10.

Wojciechowski R., Społeczno-polityczne i ekonomiczne aspekty realizacji polityki ekologicznej, [w:] Administracja publiczna a ochrona przyrody. Zagadnienia ekonomiczne, spoleczne oraz prawne, M. Górski, D. Niedziółka, R. Stec, D. Strus (red.), Warszawa 2012.

Wojcieszak M., Szalaty N., Wyduba W., Wsparcie rolnictwa zrównoważonego w Polsce w ramach PROW 2014-2020 na przykładzie działania rolno-środowiskowo-klimatycznego, „Problemy Rolnictwa Światowego", 2018, t. 18, nr 33.

Wołpiuk W., Zasada zrównoważonego rozwoju. Zasada konstytucyjna czy zasada polityki społeczno-ekonomicznej w zakresie ochrony środowiska, „Zeszyty Naukowe Wyższej Szkoły Informatyki, Zarządzania i Administracji w Warszawie", 2003, z. 1.

Woś A., Konkurencyjność potencjalna polskiego rolnictwa, Warszawa 2001.

Woś A., Makroekonomiczne uwarunkowania rozwoju sektora żywnościowego, [w:] Analiza produkcyjno-ekonomicznej sytuacji rolnictwa i gospodarki żywnościowej w 2002 roku, Warszawa 2003.

Wójcicki Z., Problemy modernizacji i rozwoju infrastruktury rolniczej i wiejskiej, „Infrastruktura i Ekologia Terenów Wiejskich", 2009, nr 4

Wróbel A., Modele ochrony oznaczeń geograficznych w Unii Europejskiej i Stanach Zjednoczonych - problematyka prawna, Łódź 2015.

Wrzaszcz W., Skutki zazieleniania Wspólnej Polityki Rolnej na przykładzie gospodarstw prowadzacych rachunkowość rolna, „Roczniki Naukowe Stowarzyszenia Ekonomistów Rolnictwa i Agrobiznesu", 2017, t. 19, z. 4.

Wysokińska Z., Konkurencyjność w międzynarodowym, globalnym handlu technologiami, Warszawa 1999.

Zakolska J., Zasada proporcjonalności w orzecznictwie Trybunatu Konstytucyjnego, Warszawa 2008.

Zawalińska K., Majewski E., Wąs A., Dlugookresowe zmiany $w$ dochodach z polskiego rolnictwa na tle krajów UE, „Zeszyty Naukowe SERiA”, 2015, t. 17, z. 6.

Zawojska A., Horbowiec B., Ryzyko cenowe na rynku produktów rolno-żywnościowych: źródła, skutki i sposoby zarządzania, „Zeszyty Naukowe SGGW. Ekonomika i Organizacja Gospodarki Żywnościowej”, 2016, nr 115. 
Zdziennicki B., Kierunki usprawnień organizacyjnych kontraktacji produktów rolnych, Warszawa 1996.

Zdziennicki B., Kontraktacja produktów rolnych. Funkcje, problemy organizacyjne, Warszawa 1975.

Zdziennicki B., Umowa kontraktacji, [w:] Prawo rolne, P. Czechowski (red.), Warszawa 2017.

Ziętara W., Rola dzierżawy nieruchomości rolnych $w$ procesie przemian struktury obszarowej gospodarstw rolniczych w Polsce, ,Roczniki Akademii Rolniczej w Poznaniu”, 1999, nr 268.

Ziętara W., Sobierajewska J., Konkurencyjność polskich gospodarstw sadowniczych, „Zagadnienia Ekonomiki Rolnej”, 2017, nr 1 (350).

Zirk-Sadowski M., Wykładnia i rozumienie prawa w Polsce po akcesji do Unii Europejskiej, [w:] Polska kultura prawna a proces integracji europejskiej, S. Wronkowska (red.), Kraków 2005.

Zubik M., Gospodarstwo rodzinne - niedoceniona szansa wspótksztaltowania konstytucyjnych podstaw ustroju rolnego poprzez sadownictwo konstytucyjne, [w:] Prawne mechanizmy wspierania i ochrony rolnictwa rodzinnego w Polsce i innych państwach Unii Europejskiej, P. Litwiniuk (red.), Warszawa 2015.

Zwierzchoniewski R., Europejski Fundusz Orientacji i Gwarancji Rolnej [FEOGA]. Informator, Ośrodek Doradztwa Rolniczego Bonin, 1993.

Zwolak J., Ocena reprodukcji środków trwałych w rolnictwie polskim po 1990 roku, „Zagadnienia Ekonomiki Rolnej”, 2007, nr 1.

Żabicka-Kłopotek M., Rozporzadzenie wykonawcze jako element systemu źródeł prawa powszechnie obowiazujacego. Wybrane zagadnienia, „Przegląd Legislacyjny”, 2011, nr 2-4 (76-78).

Żmija D., System płatności bezpośrednich w Polsce w kontekście rozwiazań stosowanych w Unii Europejskiej, „Problems of World Agriculture/Problemy Rolnictwa Światowego”, 2011, t. 11, z. 1.

\section{Strony internetowe}

http://agricultura.gencat.cat/web/.content/09-desenvolupament-rural/programa-desenvolupamentrural/periode-2014-2020/enllacos-documents/fitxers-binaris/170831_programa_desarrollo_rural_catalunya_2014_2020_versio_6_1.pdf [data dostępu 30 marca 2019 r.].

http://data.consilium.europa.eu/doc/document/ST-6766-2017-INIT/PL/pdf [data dostępu 30 marca 2019 r.].

http://ec.europa.eu/eu2020/pdf/1_PL_ACT_part1_v1.pdf [data dostępu 30 marca 2019 r.].

http://trade.ec.europa.eu/doclib/press/index.cfm?id=1684 [data dostępu 6 marca 2019 r.].

http://www.europarl.europa.eu/sides/getDoc.do?pubRef=-//EP//TEXT+TA+P8-TA-2017-0197+0+

$\mathrm{DOC}+\mathrm{XML}+\mathrm{V} 0 / / \mathrm{PL} \&$ language=PL 1684 [data dostępu 30 marca 2019 r.].

http://www.europarl.europa.eu/sides/getDoc.do?pubRef=-//EP//TEXT+TA+P8-TA-2017-0197+0 +DOC+XML+V0// PL\&language=PL [data dostępu 30 marca 2019 r.].

http://www.europarl.europa.eu/sides/getDoc.do?pubRef=-//EP//TEXT+TA+P8-TA-2018-0224+0+ $\mathrm{DOC}+\mathrm{XML}+\mathrm{V} 0 / / \mathrm{PL} \&$ language $=\mathrm{PL}$ [data dostępu 30 marca 2019 r.].

http://www.minrol.gov.pl/Wsparcie-rolnictwa-i-rybolowstwa/Platnosci-bezposrednie [data dostępu 30 marca 2019 r.].

https://ec.europa.eu/agriculture/sites/agriculture/files/future-of-cap/future_of_food_and_farming communication_pl.pdf [data dostępu 20 grudnia 2017 r.].

https://ec.europa.eu/agriculture/sites/agriculture/files/future-of-cap/future_of_food_and_farming communication_pl.pdf [data dostępu 30 marca 2019 r.].

https:/ec.europa.eu/agriculture/sites/agriculture/files/rural-development-2014-2020/country-files/ fr/press-summary-13-02-2015_en.pdf [data dostępu 30 marca 2019 r.]. 
https:/ec.europa.eu/info/business-economy-euro/economic-and-fiscal-policy-coordination/eueconomic-governance-monitoring-prevention-correction/european-semester/framework/europe-2020-strategy_pl [data dostępu 30 marca 2019 r.].

https://eur-lex.europa.eu/legal-content/DE/TXT/PDF/?uri=CELEX:11957E/TXT\& from=PL [data dostępu 27 marca 2019 r.].

https://eur-lex.europa.eu/legal-content/PL/TXT/?qid=1526550660947\&uri=CELEX:52018PC0322 [data dostępu 30 marca 2019 r.].

https://eur-lex.europa.eu/legal-content/PL/TXT/?qid=1526553268422\&uri=CELEX:52018DC0321 [data dostępu 30 marca 2019 r.].

https://eur-lex.europa.eu/legal-content/PL/TXT/?qid=1526553554668\&uri=CELEX:52018PC0324 [data dostępu 30 marca 2019 r.].

https://eur-lex.europa.eu/legal-content/PL/TXT/?uri=CELEX\%3A52017XC1018\%2801\%29 [data dostępu 30 marca 2019 r.].

https://eur-lex.europa.eu/legal-content/PL/TXT/?uri=CELEX\%3A52017XC1018\%2801\%29 [data dostępu 30 marca 2019 r.].

https://eur-lex.europa.eu/legal-content/PL/TXT/?uri=CELEX:52018PC0392\&qid=1528452097687 [data dostępu 30 marca 2019 r.].

https://eur-lex.europa.eu/legal-content/PL/TXT/?uri=CELEX:52018PC0393\&qid=1528452398071 [data dostępu 30 marca 2019 r.].

https://eur-lex.europa.eu/legal-content/PL/TXT/?uri=CELEX:52018PC0394\&qid=1528452463620 [data dostępu 30 marca 2019 r.].

https://powietrze.gios.gov.pl/pjp/documents/download/102570 [data dostępu 30 marca 2019 r.]. https://www.arimr.gov.pl/fileadmin/pliki/PB_2019/Kampania_2019/zalaczniki/ARiMR_Broszura_Platnosci_bezposrednie_w_2019.pdf [data dostępu 30 marca 2019 r.].

https:/www.arimr.gov.pl/pomoc-unijna/platnosci-bezposrednie/platnosci-bezposrednie-w-roku-2018/platnosci-bezposrednie-w-roku-2018/platnosc-za-zazielenienie/dywersyfikacjaupraw.html [data dostępu 30 marca 2019 r.].

https://www.bmel.de/SharedDocs/Downloads/Landwirtschaft/LaendlicheRaeume/NRR-20142020.pdf;jsessionid=AF68A475B7D65C254B01DD030A80DDB6.1_cid376?_blob=publicationFile [data dostępu 30 marca 2019 r.].

https://www.gov.pl/documents/912055/913531/Za\%C5\%826_Stanowisko_RP_dot_pakietu_WPR_ po_2020_roku_-_COM\%282018\%29_392_393_394.pdf/cd795bba-aabf-6b2a-2c9e-f6d8dc5182 6c [data dostępu 30 marca 2019 r.].

https://www.gov.pl/web/rolnictwo/platnosc-dla-mlodych-rolnikow2 [data dostępu 30 marca 2019 r.]. https://www.gov.pl/web/rolnictwo/platnosc-za-zazielenienie2 [data dostępu 30 marca 2019 r.]. https://www.saarland.de/dokumente/thema_landwirtschaft/SEPL_2014-2020_5.0.pdf [data dostępu 30 marca 2019 r.].

https://www2.gov.scot/Resource/0054/00544562.pdf [data dostępu 30 marca 2019 r.]. 
